UNIVERSIDADE DE SÃO PAULO

FACULDADE DE FILOSOFIA, LETRAS E CIÊNCIAS HUMANAS DEPARTAMENTO DE GEOGRAFIA

PROGRAMA DE PÓS-GRADUAÇÃO EM GEOGRAFIA HUMANA

MÔNICA MARIA FERREIRA TELES

\title{
A cartografia turística de João Pessoa e seus discursos sobre a cidade
}

VERSÃO CORRIGIDA

v. 1 
UNIVERSIDADE DE SÃO PAULO

FACULDADE DE FILOSOFIA, LETRAS E CIÊNCIAS HUMANAS

DEPARTAMENTO DE GEOGRAFIA

PROGRAMA DE PÓS-GRADUAÇÃO EM GEOGRAFIA HUMANA

\section{A cartografia turística de João Pessoa e seus discursos sobre a cidade}

Mônica Maria Ferreira Teles

Tese apresentada ao Departamento de Geografia da Faculdade de Filosofia Letras e Ciências Humanas da Universidade de São Paulo, para a obtenção do grau de doutora em Geografia.

Orientador: Manoel Fernandes de Sousa Neto

v. 1

VERSÃO CORRIGIDA

Assinatura do orientador 
A Dona Lourdes e Seu Ferreira

Dedico 


\section{AGRADECIMENTOS}

A realização deste trabalho só foi possível graças à colaboração de muitas pessoas às quais tenho imensa gratidão. No entanto, a algumas pessoas farei questão de agradecer de forma especial.

Primeiramente o meu agradecimento ao Programa de Pós Graduação em Geografia da Universidade de São Paulo, nas pessoas de todos os funcionários e professores.

Iniciar essa jornada não teria sido possível sem o incentivo, o apoio e a credibilidade dispensados a mim pelo Prof. Manoel Fernandes de Sousa Neto que, mais do que um orientador, foi base de apoio logístico e principalmente emocional para as angústias e as inseguranças comuns deste processo. Foi ele que plantou a idéia e me convenceu de que eu seria capaz. A você Nando meu afeto e minha gratidão infinitos. Neste ensejo, quero agradecer também de forma especial ao Prof. Dr. Antonio Carlos Robert Moraes pelo apoio me concedendo o aceite para orientação.

Pensar em escrever este texto me faz lembrar o início de tudo, quando compartilhei do mesmo sonho com o amigo Renato Alves, a quem agradeço todo o carinho, o apoio e o cuidado nas nossas idas e vindas por São Paulo.

Agradeço muito especialmente a Marcos Praxedes, companheiro de todas as horas, pelas risadas, músicas, cervejas e cafezinhos, mas principalmente pela companhia, afeto e compreensão nas horas mais difíceis.

Não poderia deixar de agradecer aos familiares que sempre estiveram na torcida, às minhas filhas, Yanna e Ohana, pelo apoio e incentivo em todos os momentos, por se fazerem presentes na minha vida e, principalmente, por entenderem as minhas ausências em incontáveis momentos. A Fernando Domingos, meu amigo-irmão, a quem agradecer é pouco, em breve será você a fazer doutorado e terei oportunidade de retribuir por tudo, muito obrigada por existir na minha vida. A Francisca Fam, minha amiga-irmã, que sempre me acolheu nos finais das tardes de domingo para as melhores conversas regadas pelos melhores pães, chás, vinhos e cafés.

Aos amigos Adauto Gomes e Antônio Vicente pelo carinho, preocupação, disponibilidade em me receber em Recife durante as minhas procuras por mapas. A Adauto especialmente pela leitura cuidadosa do texto.

Minha gratidão a Andrezza, também pelo mesmo cuidado que teve ao ler meu texto, pelas dicas e sugestões muito importantes, além do carinho, afago e afeto. A kelly Cristine pela amizade e pelo exemplo de pessoa forte e ao mesmo tempo delicada que é.

A Professora Regina Gonçalves pela leitura e correção minuciosa do texto e pelo aceite em participar da banca de defesa. Aos demais professores da banca Fernanda Padovesi, Rita Ariza da Cruz e Paulo Godoi meus agradecimentos pelas contribuições muito pertinentes.

Aos amigos da UFPB que me ajudaram com empréstimos de livros, principalmente a Priscila e Helena, que sempre se dispuseram a emprestar quantos livros eu necessitasse. A Icilma Cavalcanti a quem agradeço a atenção e a boa vontade em me enviar os dados e informações sobre o turismo na Paraíba.

As instituições Universidade Federal da Paraíba, PBTUR, Instituto Ricardo Brennand e Instituto Histórico e Geográfico Paraibano, agradeço a disponibilidade de livros, mapas e documentos para a pesquisa.

Enfim, a minha gratidão a todos que contribuíram de forma direta ou indireta no desenvolvimento deste trabalho. 


\section{RESUMO}

A cartografia é a arte de transformar o espaço numa versão reduzida da realidade, numa proporção capaz de ser apropriada e transportada através dos mapas. Pesquisá-los é viajar quilômetros em um segundo e poder retornar no mesmo instante. Os mapas são capazes de guardar consigo uma parte importante da história social do espaço, na medida em que traduzem em uma imagem o contexto social da época em que foram elaborados. No entanto, sendo os mapas o resultado de um processo histórico e social, eles adquirem uma grande carga de subjetividade. No ato de comunicar sobre o espaço os mapas transmitem discursos carregados de ideologias, muitas vezes relacionadas com o poder e a apropriação do espaço. O objetivo desta pesquisa de doutoramento foi analisar os discursos emitidos por uma série de mapas turísticos sobre a cidade de João Pessoa. A análise foi feita através de uma leitura que buscou ultrapassar o sentido literal e propondo uma compreensão da realidade sob a perspectiva da Cartografia Histórica. Para tanto foi necessária uma compreensão da história inicial da produção do espaço da cidade e de seu desenvolvimento mais recente, levando em conta também o atual contexto do turismo na cidade. Os mapas foram analisados sob o ponto de vista crítico, buscando identificar as contradições e conflitos através dos descuidos, exageros e omissões contidos nas suas informações.

Palavras-chave: Cartografia turística - Turismo - Mapas turísticos - História da Cartografia - Cartografia crítica 


\begin{abstract}
Cartography is the art of turning the space into a reduced version of reality, in a proportion that can be appropriated and transported through the maps. Researching them means being able to travel miles in a second and to return at the same moment. The maps are able to keep an important part of the space social history since they reflect the social context of the time they are made. However, the maps are the result of a historical and social process, they acquire a great deal of subjectivity. On their communication about space, the maps convey information laden with ideologies often related to authorities and the space appropriation. The aim of this doctoral research was to analyze the discourse issued by touristic maps of João Pessoa city. The analysis was carried out by performing a reading of the maps aiming to go beyond the literal meaning of information and by proposing an understanding of reality from the perspective of Historical Cartography. For this purpose it was required an understanding of the early history of the space city formation and its latest development as well as considering the current tourism context in the city. The maps were analyzed from a critical point of view, seeking to identify the contradictions and conflicts through the negligences, exaggerations and omissions contained in their information.
\end{abstract}

Keywords: Touristic Cartography - Tourism - Touristic Maps - History of Cartography - Critical Cartography. 


\section{LISTA DE MAPAS}

Mapa 1 - Mapa "Afbeeldingder stadt en fortressen van Parayba" de Nicolaes Visscher

Mapa 2 - Mapa de reconstituição da área urbana de João Pessoa em diversos períodos.

Mapa 3 - Mapa turístico de João Pessoa, com destaque para os três discursos identificados para a cidade.

Mapa 4 - Mapa turístico de João Pessoa, com destaque para os textos de apresentação da cidade contendo os discursos identificados como geográfico, da natureza e histórico

Mapa 5 - Mapa A Paraíba e seus encantos.

Mapa 6 - Mapa Descubra a Paraíba.

Mapa 7 - Mapa Paraíba aqui o sol nasce primeiro.

Mapa 8 - Mapa-encarte da Revista PHILIPÉIA.

Mapa 9 - Mapa Turístico de Tambaú.

Mapa 10 - Mapa da Grande João Pessoa e Cabedelo.

Mapa 11 - Material publicitário do Manaíra Shopping em formato de folder com um mapa turístico de João Pessoa

Mapa 12 - Shopping Mapa João Pessoa.

Mapa 13 - Mapa-Guia turístico de João Pessoa.

Mapa 14 - Mapa turístico de João Pessoa do ano de 2011

Mapa 15 - Mapa turístico de João Pessoa com detalhe da área do município de Bayeux ocupada por sinalização turística. 


\section{LISTA DE FIGURAS}

Figura 1 - Vista aérea da Estação Cabo Branco

Figura 2 - Imagem de satélite da cidade de João Pessoa.

Figura 3 - Capas de mapas com fotografias em que a Lagoa é colocada como destaque principal.

\section{LISTA DE TABELAS}

Tabela 1 - Ranking dos 11 países que mais geram renda proveniente da atividade turística

Tabela 2 - Totais de receita e despesa cambial turística e superávit ou déficit do Brasil - Período de 1990 a 2012

Tabela 3 - Participação relativa das UFs no emprego formal das ACTs na Região Nordeste - Dezembro de 2008

Tabela 4 - Pesquisa anual do desempenho do turismo na Região Metropolitana de João Pessoa - Distribuição da amostra segundo a razão da RMJP como destino turístico - Ano 2014

Tabela 5 - Pesquisa anual do desempenho do turismo na Região Metropolitana de João Pessoa - 2014 - Distribuição da amostra segundo classificação dos serviços turísticos na RMJP.

Tabela 6 - Pesquisa anual do desempenho do turismo na Região Metropolitana de João Pessoa - 2014 - Distribuição da amostra segundo os pontos positivos encontrados na Paraíba

Tabela 7 - Pesquisa anual do desempenho do turismo na Região Metropolitana de João Pessoa - 2014 - Distribuição da amostra segundo os pontos negativos citados pelos turistas na Paraíba...... 


\section{LISTA DE GRÁFICOS}

Gráfico 1 - Chegadas internacionais de turistas no mundo no período de 1995 a 2014

Gráfico 2 - Chegadas de turistas estrangeiros no Brasil $\mathrm{X}$ receita cambial

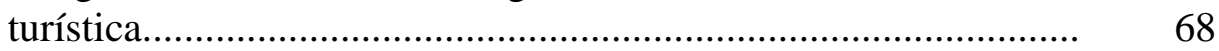

Gráfico 3 - Estrutura das Atividades Características do turismo, por porte das empresas, no Brasil no ano de 2003 ................................................ 75

Gráfico 4 - Fluxo global de turistas na Paraíba no período de 2002 a 2014.....

Gráfico 5 - Fluxo global de turistas em João Pessoa no período de 2002 a $2014 \quad 79$

Gráfico 6 - Principais emissores de turistas e principais geradores de receitas no Pará....

Gráfico 7 - Principais emissores de turistas e principais geradores de receitas para o Distrito Federal

Gráfico 8 - Principais Emissores de Turistas e Principais Geradores de Receitas para Pernambuco.

Gráfico 9 - Principais Emissores de Turistas e Principais Geradores de Receitas para o R. G. do Norte.

Gráfico 10 - Principais Emissores de Turistas e Principais Geradores de Receitas para o Ceará.

Gráfico 11 - Principais Emissores de Turistas e Principais Geradores de Receitas para a Paraíba. 


\section{LISTA DE ABREVIATURAS}

\begin{tabular}{|c|c|}
\hline ACTs & - Atividades Características do Turismo \\
\hline BID & - Banco Internacional de Desenvolvimento \\
\hline BNDES & - Banco Nacional de Desenvolvimento \\
\hline $\mathrm{BNH}$ & - Banco Nacional de Habitação \\
\hline C.U.R.A. & - Comunidade Urbana para Recuperação Acelerada \\
\hline DF & - Distrito Federal \\
\hline EMBRATUR & - Empresa Brasileira de Turismo \\
\hline FGV & - Fundação Getúlio Vargas \\
\hline FIPE & - Fundação Instituto de Pesquisas Econômicas \\
\hline IBGE & - Instituto Brasileiro de Geografia e Estatística \\
\hline IFEP & - Instituto Fecomércio de Pesquisas Econômicas e Sociais da Paraíba \\
\hline IPEA & - Instituto de Pesquisa Econômica Aplicada \\
\hline OMT & - Organização Mundial de Turismo \\
\hline PBTUR & - Empresa Paraibana de Turismo \\
\hline PIB & - Produto Interno Bruto \\
\hline PLANTUR & - Plano Nacional de Turismo \\
\hline PNT & - Plano Nacional de Turismo \\
\hline PRODETUR & - Programa de Desenvolvimento do Turismo \\
\hline PRODEMA & $\begin{array}{l}\text { - Programa Regional de Pós-Graduação em Desenvolvimento e Meio } \\
\text { Ambiente }\end{array}$ \\
\hline SFH & - Sistema Financeiro de Habitação \\
\hline UFPB & - Universidade Federal da Paraíba \\
\hline UFs & - Unidades da Federação \\
\hline WTTC & - World Travel \& Tourism Council \\
\hline
\end{tabular}




\section{SUMÁRIO}

APRESENTAÇÃO

CAPÍTULO 1. A cidade sob antigos e novos olhares

$1.1 \quad$ Antigos olhares sobre a Parahyba .................................................... 24

1.2 Novos olhares sobre a cidade .......................................................... 40

1.2.1 Abastecimento de água na Parahyba: a modernidade chega às torneiras.

1.2.2 Eletricidade na Parahyba: luz para as ideias, tração para as ações ........

1.2.3 E o bonde elétrico movimenta a cidade

1.2.4 O jogo urbano: cartas marcadas no espaço da cidade

1.3 Novos desdobramentos urbanos.

1.3.1 - A década de 1920 e a importância de Saturnino de Brito

1.4 Intervenções urbanas mais recentes: a cidade e a lógica capitalista.

CAPÍTULO 2. Turismo: o novo negócio mundial?

2.1 O turismo no Brasil: Entre a realidade e a ilusão dos discursos por trás dos dados

2.2 Turismo brasileiro: o desequilíbrio na balança cambial e seu déficit histórico.

2.3 João Pessoa: Ponto de referência para o turismo da Paraíba.

2.4 Turismo como influência na produção do espaço em João Pessoa.........

\section{CAPÍTULO 3 A cidade dos mapas turísticos: linguagem, comunicação} cartográfica, discurso e poder

3.1 A análise dos mapas: o desvendar dos discursos sobre o espaço turístico da cidade

3.2 João Pessoa: um produto turístico no mercado de cidades.

3.3 O Parque Sólon de Lucena e o Hotel Tambaú: símbolos materiais do discurso turístico da cidade 
3.4 O lugar das propagandas nos mapas................................................... 143

3.5 João Pessoa: a cidade invisível............................................................ 146

CONCLUSÕES Em tempo, Reflexões acerca do fato apreendido................ 153

REFERÊNCIAS BIBLIOGRÁFICAS ......................................................... 160

Apêndice - Fichário de Mapas ............................................................................... 169 


\section{APRESENTAÇÃO}

Como geógrafa que se permite afetar pelo encantamento das paisagens naquilo que elas conservam de sua natureza e naquilo que conservam de uma natureza que lhes é inventada, sempre me deixei seduzir pela possibilidade de conhecer e desbravar espaços outros; de alteridade, de deslocamento e de novas experiências. Fazendo isso na condição de pesquisadora em alguns momentos, mas muito mais como curiosa, como desbravadora, pois é isto que toda turista é: uma estrangeira da e na paisagem, uma flâneur a caminhar comprometida apenas com as possibilidades de experimentar o novo. A vivência deste tipo de experiência com espaço é algo muito simples e intuitivo para quem faz turismo, mas trata-se de uma experiência com espaços que vão sendo inventados como espaços de sedução do outro, e como tal, vão sendo preparados para isto. Tal invenção vai se configurando articulada de forma harmônica, ou não, com outros elementos que compõem a paisagem, o meio urbano, os tipos e as práticas sociais. Para que o espaço turístico se estabeleça como tal, para que se constitua a identidade turística, que parte de si, mas que se forja em função de seus outros, é preciso que se lance mão de inúmeras práticas discursivas que se expressam e se imprimem no espaço através de diferentes linguagens e veículos, por meio dos quais este se faz representar e constitui identidades.

Pensando sobre esta teia de elementos responsáveis por engendrar e produzir esses espaços de sedução, identidade pretendida pelas cidades consideradas turísticas, os caminhos desta pesquisa de doutoramento acabaram por imbricar-se com minhas próprias subjetividades na escolha de um tema que, de forma talvez pouco técnica, pode ser classificado como uma tentativa de escalpelar alguns dos elementos e mecanismos de invenção do espaço turístico em João Pessoa. Para isso, seguimos as trilhas discursivas e não discursivas de seus mapas turísticos e daquilo que eles podem nos dizer acerca da história dessa identidade da cidade como um espaço turístico ou de sua tentativa de assim estabelecer-se.

Os diálogos com a história e historiografia da cidade de João Pessoa nos levam aos marcos e às marcas da temporalidade que abrigam a historicidade do espaço e que têm no ano de 1585 uma metáfora da origem de uma experiência social que fez do território um outro, tantas vezes nomeado e mutante. Tantas histórias contadas, tanto 
vivido cujas memórias não captaram, tantas memórias perpetuadas, tantas silenciadas. Tantas histórias lapidadas pelos artífices da memória, tantas memórias inscritas na experiência do espaço que se imprime num patrimônio (i)material da cidade. Memórias que muitas vezes escapam à pena das narrativas oriundas da operação historiográfica (CERTEAU, 2008) e da experiência espacial monumentalizada a partir dela (LE GOFF). Muitas vezes pertencentes apenas ao flâneur, aquele que faz do seu caminhar um ato leve e desapressado de experiência com o espaço, com suas metamorfoses. Ele é o "homem na multidão" de Baudelaire, de Alan Poe, também pode ser "passante" de Lima Barreto e João do Rio. Personagens que fazem do caminhar pela cidade uma arte que lhes possibilitam fazer desta uma experiência que pode ser pensada como uma poética da urbanidade caleidoscópica, um real que se estabelece no mosaico das experiências e memórias individuais e coletivas ditas e silenciadas.

É a pluralidade desta experiência poética e caleidoscópica a que nos remetemos ao pensar nas inúmeras possibilidades de narrar as representações acerca do espaço da cidade de João Pessoa. Tantas possibilidades nos desafiam e instam à compreensão de que, sejam quais forem os caminhos escolhidos, estaremos lidando com a limitação de quem se arrisca a pensar e narrar a historicidade de um espaço, que é a de trabalhar com os limites do paradigma indiciário (GINZBURG, 1998), para arquitetar narrativas verossímeis de um vivido ausente, que se presentifica a partir de indícios, com os restos de vida aos quais tentamos dar coerência e inteligibilidade.

A cidade de João Pessoa é o cenário, o mote e a inspiração deste trabalho, que procurou pensá-la a partir da constituição de seus espaços tentando dialogar com suas histórias, contadas em interlocução com a historiografia. Campo responsável por intermediar nossas relações com o passado da cidade nos ajudando a refletir sobre os eventos que marcam os conflituosos anos de ocupação do território pelos portugueses no século XVI. Desde o estabelecimento do povoamento de Nossa Senhora das Neves em 1585, que logo viria a chamar-se Filipéia de Nossa Senhora das Neves (1588), quando o Brasil esteve integrado, por meio da União Ibérica, ao império Espanhol e o nome homenageava o próprio rei. Por um curto tempo foi Frederikstad (1634), quando, durante o período em que esteve sob domínio holandês, era a cidade de Frederico, passando, com o declínio holandês no Brasil, em 1654, a chamar-se de Parahyba do Norte. Nome este a partir do qual se forja sua identidade mais forte, até que os acontecimentos da chamada 
Revolução de 30, pelos seus desdobramentos políticos, leva embora tal identidade impondo-lhe o atual nome de João Pessoa. Por trás de tantas identidades há muitas histórias engendradas, muitas narrativas pelo caminho, narrativas estas com as quais procuramos dialogar na primeira parte do trabalho, não com a pretensão de dar conta de toda a história da cidade de João Pessoa de suas origens aos dias atuais, mesmo porque entendemos que um texto deste tipo não nos caberia nem para a proposta do trabalho nem mesmo por força de ofício. Nosso diálogo com a história e a historiografia tem um sentido didático de produzir uma síntese histórica que pudesse ser abrigada no corpo deste trabalho para consubstanciar às analises que se seguirão.

Nesse sentido, procuramos partir daquilo que parte da historiografia identifica como os passos originais do povoamento. Desde os conflitos internos entres os indígenas inflamados e patrocinados muitas vezes pelos europeus, como é o caso do conflito entre Tabajara e Potiguara, que foi decisivo para o estabelecimento da Capitania Real da Parahyba; seguindo pelos caminhos que levam à formação de uma cidade que busca, especialmente no período republicano, estabelecer os pilares da modernidade e da modernização. Escrever um texto de síntese histórica em um trabalho como este é como ceifar em um campo que não se semeou, a colheita precisa ser breve, mas respeitosa e isto, neste caso, nos faz entender que, em alguns pontos, o texto pode vir a ser fragilizado pelas lacunas que abriga.

No segundo capítulo do trabalho nosso diálogo é com o Turismo, pensado aqui enquanto um campo, uma atividade e uma prática social. Nesse sentido, procuramos estabelecer um jogo de escalas onde a atividade se coloca como importante fator de fomento da economia e da constituição dos territórios das cidades. Isto identificado como um fenômeno historicamente marcado pelo pós Guerra, a partir da década de 1950. Pois, as conseqüentes mudanças geopolíticas incentivaram o fluxo de pessoas pelo mundo, levando ao desbravamento de fronteiras e de culturas pelo estabelecimento de intercâmbios entre os povos. O turismo se transforma numa atividade marcada por projetos complexos que buscam incentivar o fluxo de um número cada vez maior de pessoas, afetando as comunidades visitadas e as pessoas que as visitam. Fato que, de certo modo, acaba por impor novos conteúdos e novas dinâmicas culturais aos lugares e ao modo de vida das pessoas. 
O jogo de escala se estabelece no sentido de contextualizar os debates sobre a emergência e a importância que a área de turismo assume atualmente na economia. Desta forma o turismo é aqui problematizado em linhas históricas e econômicas mais gerais, seguindo para uma contextualização em nível de Brasil. Procuramos refletir também sobre um contexto mais local ao pensar a cidade de João Pessoa inserida e marcada por demandas que se estabelecem em função de uma identidade turística para a cidade e que trazem intervenções na configuração do seu espaço.

Assim, nesta parte, nosso diálogo se volta mais uma vez para a interlocução com a história, à medida que fomos buscar em fenômenos sociais do pós Segunda Guerra mediante as radicais transformações econômicas do período, o estabelecimento de condições e de demandas para a expansão do turismo no mundo transformando-se em uma espécie de negócio mundial rapidamente cooptado pelo sistema produtivo e financeiro. Assim, procuramos compreender o avanço do turismo quanto à sua relevância financeira em comparação com outros setores produtivos da economia mundial, marcado por suas particularidades, especialmente quanto à sua alta flexibilidade como atividade social e econômica.

Ao analisarmos o contexto do turismo no Brasil procuramos dialogar com o não dito de alguns números, para refletir em que medida a expansão do setor tem evoluído e desenvolvido em áreas específicas. para a condição de desenvolvimento para as áreas afetadas por tais atividades. Ou seja, não focamos nos potenciais para o turismo, mas, nos discursos forjados através dos dados sobre o turismo que dão conta, por exemplo, de que o Brasil é apontado como principal destino turístico da América do Sul, e responsável pelo crescimento e consolidação deste desempenho no contexto das previsões no âmbito mundial (BRASIL, 2007). E, neste sentido, procuramos pensar como isto se tem traduzido num fenômeno de geração de emprego e renda fazendo desta uma importante atividade impulsionadora da economia, além de possibilitar a fixação das pessoas em empregos nos seus lugares de origem, proporcionando uma grande variedade de postos de trabalho com diversos níveis de formação, além de gerar demanda para prestação de serviços fomentando os pequenos investidores e trabalhadores freelance (BRASIL, 2013).

Contudo, tais elementos são apenas as pontas de um iceberg. Ao passo que a pesquisa foi se desenrolando percebemos que os números da economia do turismo dão conta de que o Brasil figura num cenário positivo para o PIB em relação à entrada de 
turistas estrangeiros e a geração de empregos. Por outro lado, há desequilíbrio cambial que se estabelece no setor e acaba sendo escamoteado, pois é preciso compreender a importância da atividade para a economia considerando não apenas o fluxo de entradas e saídas de turistas no país, mas também a questão do montante de divisas deixadas pelos turistas, tanto aqui no país pelos estrangeiros, como lá fora pelos brasileiros (RABAHY, 2006).

O turismo ainda carece de análises mais aprofundadas e, principalmente, de variáveis bem definidas que viabilizem um melhor conhecimento deste fenômeno, que tem crescido no Brasil e no mundo. Apesar de encontradas muitas carências referentes à dados sobre a realidade do turismo local, buscamos apresentar um panorama geral das variáveis aqui consideradas mais relevantes nos estudos ligados à temática, buscando sempre dar enfoque à cidade de João Pessoa, claro que, em alguns momentos, tivemos que lidar com as limitações impostas pela natureza dos dados manuseados.

$\mathrm{Na}$ tentativa de dar uma face a esta atividade procuramos dados que tipificam o turismo na cidade de João Pessoa, dando conta de tratar-se de um destino privilegiado para o lazer. Fato este que parece estar atrelado às belezas naturais por um lado e, por outro, à necessidade de uma projeção nacional que fosse capaz de impulsionar o turismo de negócios na cidade. Claro que esta é uma observação que serve apenas à guisa introdutória e não deve ser tomada isoladamente.

Trabalhamos, por exemplo, com dados que indicam que, dentre as três principais razões que levaram os turistas a escolher João Pessoa em 2014 como o destino de sua viagem estão as belezas das praias, a visita a parentes e amigos e os atrativos naturais (IFEP, 2014). Em termos de um contexto mais ampliado, não desconsideramos o fato de que, dada à sua condição de capital, às condições de infraestrutura de estradas e de contar com o principal aeroporto do Estado, a cidade acaba por destacar-se quanto ao turismo em relação aos demais municípios da Paraíba.

O turismo deve ser pensado no patamar das práticas sociais capazes de repercutir na forma como se forja a experiência com o espaço, que reverbera na configuração da geografia deste, já que, o apelo turístico sempre se estabelece em função da espacialidade, seja por ser abrigo da natureza, seja por abrigar a história, seja por abrigar sujeitos, seja por abrigar práticas. Todos estes elementos são indissociáveis da vivência do espaço que acaba se configurando como o elemento adjetivador da experiência social. 
Contudo, as formas de vivenciá-lo são frutos da casualidade, visto que, as marcas da cultura se imprimem por toda parte no sentido de forjar a identidade de tais espaços. Não é por acaso que comumente as paisagens urbanas e rurais são alteradas em função dos apelos turísticos. Desta forma, o espaço turístico se forja em função de receber turistas e em função de ser capaz de acolhê-los de acordo com as suas demandas.

E este é o sentido que procuramos nos apropriar para pensar o turismo na sua singular condição de ser um fenômeno essencialmente urbano, constituído num âmbito capitalista do mundo da mercadoria, cuja grande particularidade está na forma como se relaciona com o espaço. Este, por sua vez, não se constitui como mercadoria acabada e pronta, mas está marcado pela dinâmica social que o produz e reproduz de forma muitas vezes descoordenada, visto que às vezes foge às tentativas de planejamento e de uma disciplina do espaço.

Assim, podemos dizer que o espaço turístico é aquele em que a sua produção e reprodução se dão preponderantemente em função da atividade do turismo, sendo esta a mais relevante dentre as outras na produção deste espaço. E este é o elemento central que nos possibilita discutir a influência do turismo na produção do espaço urbano de João Pessoa aliançado com um debate de consumo do espaço que segue para encontrar as discussões sobre o crescimento da atividade turística no Nordeste. Passamos a pensar o turismo como o principal agente de produção do espaço litorâneo regional e, consequentemente, também da cidade de João Pessoa, favorecida, neste sentido, por ainda resguardar suas praias urbanas despoluídas, além de sol e calor em boa parte do ano.

Para refletir sobre esses elementos, procuramos relacioná-los às políticas públicas marcadas por projetos voltados para o fomento do turismo na cidade e para uma tipificação da identidade turística que vai revestindo a cartografia turística da cidade e avançando para além de outras territorialidades, mas, principalmente, sobre o litoral.

A terceira parte do trabalho intitulada A João Pessoa dos mapas turísticos: linguagem, comunicação cartográfica, discurso e poder traz consigo a busca por problematizar as representações do espaço comunicadas a partir de uma série de mapas da cidade, pensados aqui em sua potencialidade como veículos discursivos portadores de dizeres sobre o espaço, mas que não estão isentos de intencionalidades, nem alheios às dinâmicas de poder que marcam os discursos. 
Os mapas turísticos utilizados trazem consigo uma intencionalidade clara de venda de uma imagem e uma identidade sobre os espaços da cidade que procuramos problematizar. Para empreendermos suas análises buscamos interlocuções que nos possibilitaram problematizar conceitos voltados para a constituição de uma linguagem e uma prática de comunicação do espaço no qual os mapas foram inseridos como elementos discursivos. Uma importante contribuição para pensar as práticas discursivas como práticas de poder na forma como os mapas vão sendo pensados ao longo do trabalho foi o de Michel Foucault para quem o discurso é prática social. De forma que, como estão imbricadas com as relações de poder e saber, mutuamente afetadas, o que implica dizer que enunciados e visibilidade, textos e instituições, ver e dizer são elementos constituintes de práticas sociais indissociáveis das relações de poder que lhes dão suporte e atualizam.

Dessa forma, pensar os discursos a partir daquilo que nos sugere Foucault significa transpor a dimensão da coisa em si, ou seja, estes se estabelecem para além de suas dimensões gráficas, dos usos da letra, das formas linguísticas, da palavra. Eles não devem ser percebidos apenas como uma expressão pura de algo: trazem consigo regularidades intrínsecas a si mesmos, em função das quais se pode definir uma teia conceitual própria. E é justamente este o grande elemento do autor para definir suas referências, visto que, para o autor, as regras de formação dos conceitos não residem na mentalidade nem na consciência dos indivíduos. Pelo contrário, se inscrevem no próprio discurso e se impõem a todos aqueles que falam ou tentam falar dentro de um determinado campo discursivo (FOUCAULT, 2005, p.70). É, pois, neste sentido, que nos apropriamos dos mapas como elementos discursivos, entendendo que sua leitura transpõe uma literalidade que na verdade inexiste. Seguimos em busca das subjetivações dentro de um não dito da teia discursiva no qual os mapas se inserem, na busca por visibilizar elementos constitutivos do discurso que não se dão a ver todo o tempo.

Buscamos dialogar com os mapas em sua própria historicidade, assumindo-os como documentos históricos, filhos de seu tempo, mas cuja análise estará sempre marcada pelas questões e os olhares do presente. É neste sentido que os mapas são aqui pensados, não apenas como imagens que podem ser verdadeiras ou falsas, são textos escritos sobre um mundo social, compostos a partir de relações de poder que geram forças desiguais, entre práticas e prioridades culturais diversas. 
Contudo, ainda seguindo uma guisa introdutória, é importante que se diga que os mapas turísticos, utilizados como objetos desta análise, não chegam a ser considerados pelos cartógrafos como modelos científicos e objetivos de representação do espaço. No caso dos mapas turísticos tratam-se de mapas temáticos, direcionados a um público específico e apresentam a característica de serem especialmente retóricos, articuladores de um discurso de convencimento acerca de uma ideia central, possuindo uma credibilidade capaz de tornar verdade uma retórica.

Por isso quando se trata especialmente desses mapas não podemos, de forma alguma, destituir-lhes suas intencionalidades. Assim, trabalhamos aqui com a perspectiva de que estes mapas fazem parte de um complicado jogo que se joga no espaço.

Em termos metodológicos, tivemos que lidar com o desafio de conseguir empreender uma leitura desses mapas turísticos, as representações da imagem da cidade à luz da cartografia histórica, sem negligenciar o processo de produção da cidade e seu desenvolvimento dentro do contexto do capitalismo, evidenciando desigualdades e conflitos sociais oriundos deste processo e refletidas ou ocultadas nos mapas.

A cartografia histórica foi nossa principal bússola na orientação de nossas investigações que procuraram apresentar veículos discursivos que trazem consigo não apenas uma informação sobre o espaço geográfico, mas vão além, à busca por forjar-lhes identidades. Consideramos assim, uma perspectiva de cartografia que dá conta da ligação entre o mapa e as dinâmicas do poder, especialmente o político e o econômico, refletidos nos discursos e incidindo efetivamente na produção social do espaço.

Assim, a tônica deste trabalho esteve voltada para o enfoque dos mapas como elementos discursivos potencialmente portadores de ideologias e representações do real que favorecem a reprodução e a manutenção de um status quo, onde poucos detêm o poder de narrar, a si mesmo, os outros e de nomear, identificar e narrar os espaços.

Em termos de problematizações centrais podemos dizer que as questões fundamentais aqui postuladas podem ser relacionadas na seguinte ordem: como os mapas turísticos da cidade de João Pessoa expressam o processo de transformação de seu espaço e da forma como este é apropriado? De que forma eles colaboram no discurso da necessidade de um espaço cada vez mais voltado aos pré-requisitos das atividades 
turísticas? Buscamos, ainda, identificar quais as histórias sobre o espaço da cidade que são contadas, ou ocultadas, através das imagens destes mapas.

O sentido de constituir o espaço turístico fundamentalmente está relacionado à construção de uma identidade, uma imagem sobre este espaço que possa ser veiculada e vendida, apropriada para o consumo. Portanto, procuramos também problematizar a cidade de João Pessoa como um produto turístico no mercado de cidades, a partir de elementos midiáticos e publicitários que se voltam para atribuir-lhe identidades que possam ser facilmente consumidas pelo mercado turístico. São exemplos os slogans que a identificam como: "João Pessoa, cidade verde", “João Pessoa, ponto extremo oriental das Américas", "João Pessoa, cidade de se viver" e "João Pessoa, uma cidade de quatro séculos".

Buscando uma idealização da cidade voltada para seu estabelecimento como espaço de consumo do turismo através de seus símbolos materiais do discurso turístico da cidade, consideramos que ícones como o Parque Solón de Lucena e o Hotel Tambaú são importantes exemplos de como as construções simbólicas são eficazes na tentativa de imprimir perspectivas de mundo capazes de rememorar constantemente a presença do poder estabelecido. Por isso que nos atemos a eles ao longo do trabalho considerando que “[...] valorizados na paisagem urbana contemporânea parecem ganhar esta autonomia de estátuas que nos vigiam para sermos reproduzidos por elas" (LUCHIARI, 2005, p. 96), como se assumissem um sentido panóptico sobre o cotidiano da cidade.

No que se refere à cidade de João Pessoa não é difícil apontar alguns desses monumentos urbanos presentificados no imaginário da população, a saber: a Lagoa do Parque Solon de Lucena, o Hotel Tambaú, o Farol do Cabo Branco, a Igreja de São Francisco, o Hotel Globo e o mais novo, ainda em processo de construção simbólica, mas já muito presente no imaginário local, a Estação Cabo Branco - Ciências Cultura e Artes. Na nossa análise voltamos o foco para a Lagoa do Parque Solón de Lucena e o Hotel Tambaú por estes se constituírem, dentro do contexto, como os mais relevantes. O parque por sua relação com a temporalidade e com a história da cidade, sempre se fazendo presente nas representações cartográficas mais antigas, e o hotel pelo papel que tem dentro do contexto do turismo local.

Mas nem tudo é fala, é visibilidade. Ao tratar de João Pessoa como a cidade invisível o trabalho estará fazendo referência aos silêncios toponímicos, que têm relação 
estreita com o espaço e que estão diretamente associados à dinâmica de configuração das relações de poder no que se refere a quem tem o poder de estabelecer os discursos que procuram dar o tom da produção e do consumo dos espaços da cidade. Podemos dizer que, simbolicamente, trata-se de um fato importante e serve de atestado para confirmar a posse real ou simbólica de determinado espaço. De maneira contrária, o esvaziamento toponímico do espaço de um mapa elimina simbolicamente aquele lugar, pois, se o lugar não está no mapa, é como se ele não existisse no mundo real. Assim, como veremos, os mapas turísticos imprimem elementos que identificam a cidade ao mesmo tempo em que silenciam e ocultam elementos, desenhando, ao final, uma face que não integra e não identifica a dinâmica vivenciada no espaço. Ou seja, procuram vender um produto que acaba por existir muito mais no plano discursivo do que no sentido de uma experiência do espaço.

Ao final, esta introdução é um convite para uma caminhada pelos caminhos da história e da cartografia da cidade de João Pessoa a partir de um texto marcado pelos encantos e contradições deste que é um espaço de sedução, mas que acaba sendo representado apenas de forma imperfeita, dado os limites com os quais a escrita precisa lidar, enquanto constituidora de narrativas e análises muito pontuais sobre o real que busca representar. 


\section{Capítulo 1}

\section{A cidade sob antigos e novos olhares}

Pensar a cidade e suas memórias é lidar também com seus esquecimentos, assim como ela, para existir, precisa conviver com suas demolições, pois a cidade é sempre a nova e a antiga que se entrelaçam na trama do tempo e da historicidade. É dessa forma que procuro pensar a cidade de João Pessoa, na multiplicidade das mudanças e permanências de uma cidade que fisicamente ensaia um 'estar pronta', mas que jamais abandona a dinâmica de seus avanços e recuos, daquilo que edifica e do que demole. Como fenômeno real é visível e palpável. No entanto, sua vitalidade, sua pulsação, seu movimento constante a fará sempre inacabada, sempre haverá algo novo a acrescentar, seja a construção de uma casa numa rua qualquer, seja o projeto de um viaduto ligando um lugar a outro. A cidade nunca terá a prerrogativa de uma obra, no sentido do resultado de uma produção total e terminada.

A cidade é dinâmica, não é à toa que Santos (1988) faz dela uma metáfora da linguagem escrita que, mesmo baseada numa estrutura da língua, apresenta um processo contínuo de criação e recriação sofrendo influências diversas de diversos agentes. Seu tom de incompletude a afasta de um sentido de absoluto, fazendo-a agarrar-se à sua dimensão de relatividade. Para ele,

tal como na linguagem falada, os praticantes do espaço não vivem pensando em regras de gramática e de sintaxe para se expressarem. A palavra não costuma discursar sobre a estrutura da língua que é falada através dela; discursa com essa estrutura apenas. As relações espaciais, portanto, apesar de reais e indispensáveis, tendem a ser práticas do inconsciente (SANTOS, 1988).

A metáfora da linguagem também pode ser a da revolução. Lefebvre (1999) trata do processo de transformação das cidades considerando-o como uma revolução urbana, a partir da qual “[...] o rural, o industrial, o urbano, sucedem-se” (p. 77). Segundo o autor, revolução urbana pode ser designada como:

[...] o conjunto das transformações que a sociedade contemporânea atravessa para passar do período em que predominam as questões de crescimento e de industrialização (modelo, planificação, programação) ao período no qual a problemática urbana prevalecerá decisivamente, 
em que a busca das soluções e das modalidades próprias à sociedade urbana passará ao primeiro plano (LEFEBVRE, 1999, p. 19).

Para o autor, “o urbano (abreviação de 'sociedade urbana') define-se portanto não como realidade acabada, situada, em relação à realidade atual", mas sim como "uma prática social em marcha, a prática urbana em via de constituição, apesar dos obstáculos que a ela se opõem" (LEFEBVRE, 1999, p. 28).

No decorrer do texto, o termo cidade será usado incontáveis vezes. No entanto, o termo deverá ser considerado no sentido amplo definido por Lefebvre como esta "prática urbana em via de constituição" cuja produção é feita pela sociedade da qual faz parte.

É na marcha do vivido, da cidade que é parte de nossas vidas enquanto experiência que propomos, nesta primeira etapa do trabalho, historicizar aquilo que a historiografia elencou como sendo os primeiros passos da cidade da Parahyba ao seguir na direção da marcha em busca desta prática social cada vez mais urbana.

A cidade não é apenas dinâmica em si, mas há em torno dela uma série de questões e curiosidades que se apresentaram quando nos lançamos em busca de desvendá-la. Conhecê-la a partir das faces que lhes eram/são atribuídas, narradas pela polifonia de estudos que se multiplicam acerca de suas problemáticas, social, econômica, urbana, ambiental, de transporte, de gestão, de turismo. Trata-se de uma produção recente de estudos teóricos e empíricos, que têm sido desenvolvidos e publicados através dos programas de pós-graduação da Universidade Federal da Paraíba ${ }^{1}$, os quais vêm se somando a outros anteriores e já considerados importantes sobre a cidade.

Dos estudos sobre a cidade aqui citados, destaco a tradição historiográfica que conta com as obras Mello (1995, 1987, 2002), Aguiar (1993, 1999, 1989), Almeida (1997, 2005), Medeiros (1994), dentre outros, além dos trabalhos de Janete Lins Rodriguez (1980, 1981), Madruga (1992), Palmeira (1997) e Maia (2000).

A ocupação do espaço de uma cidade em seus primeiros passos parece-nos um ponto de partida interessante, talvez por ser uma abordagem já clássica, além de ser um caminho importante na compreensão da natureza das mudanças ocorridas no processo de

\footnotetext{
${ }^{1}$ Especialmente os programas de Pós-Graduação de Arquitetura e Urbanismo, PRODEMA, Engenharia Urbana, Geografia, História, Sociologia.
} 
produção de seu espaço urbano e, neste sentido, possibilita traçar um perfil histórico do surgimento da cidade que lhe confira inteligibilidade.

Iniciamos pela formação de seu sítio urbano, o desenvolvimento da área chamada de centro histórico, abordando períodos mais recentes onde procuramos entender a evolução urbana da cidade, tendo em vista a compreensão também dos desdobramentos mais recentes entre a questão urbana e o turismo. O título do presente capítulo "A cidade de João Pessoa: sob velhos e novos olhares" procura justamente evidenciar uma visão sobre a cidade que tenta mesclar olhares mais afastados no tempo (que procuram dar conta de um passado mais longínquo) com percepções e representações mais contemporâneas da cidade, evidenciando suas novas funções e características. Faremos isso por meio de uma articulação entre diferentes campos epistemológicos que se propõem a pensar, narrar e representar o desenvolvimento urbano atual como uma realidade que se constrói como um mosaico montado de saberes. Para a cidade estudada, nesta primeira parte do trabalho, utilizaremos a denominação de Parahyba, que foi seu nome oficial até a década de 1930. No decorrer do trabalho iremos passar a nos referir à cidade como João Pessoa adotando, portanto, o topônimo atual.

\section{1 - Antigos olhares sobre a Parahyba}

Estudar a cidade no Brasil nos leva inevitavelmente à análise do processo de colonização e as consequentes formações territoriais que o compõem e tendem a ser o registro de nascimento de muitas cidades. O papel das aglomerações urbanas nos momentos iniciais de apropriação de terras era o de demarcar e legitimar a expansão da posse do território pela Coroa portuguesa. Esta estratégia foi muito eficiente neste processo efetivando a formação de vilas, freguesias, povoados e cidades por toda a extensão do território a partir do século XVI. O povoamento era uma necessidade, ao mesmo tempo em que era uma estratégia, pois a existência desses núcleos urbanos eram o grande marco referencial da presença e do poder político e administrativo da Coroa portuguesa, ainda que esta se desse mais no plano simbólico do que em termos práticos.

A empresa colonial, cara e cheia de incertezas, estabeleceu-se fincada nos princípios da fé e da prosperidade vindoura. Não por acaso foi ela, a fé, a guardiã da presença portuguesa nos trópicos. Por guardiã entenda-se o importante papel que o 
imaginário religioso cristão católico teve na legitimação da ocupação territorial e no estabelecimento de povoamentos coloniais, os quais se fizeram de forma consorciada com a e Igreja católica.

A Igreja não apenas incentivava o povoamento, mas era ela própria um elemento de gerenciamento das relações sociais que se estabeleciam nesses lugares, fosse pela importância do papel da catequese para a expansão da fé católica num contexto de Contra Reforma, fosse por meio da doutrinação daqueles que já eram da fé. De modo que a doutrinação os mantivesse firmes em seus princípios, sendo a própria Igreja responsável pela fundação e expansão de diversos núcleos urbanos na colônia. Esses núcleos eram controlados pelo estado e pela Igreja e tinham a função, além da legitimação da posse do território, de viabilizar a exploração dos recursos naturais da colônia através do escoamento das mercadorias.

O papel específico da cidade era o de demarcar fronteiras e garantir o domínio sobre as terras conquistadas. A sobrevivência dessas cidades dependeu menos do campo do que da geopolítica administrativa realizada pela coroa portuguesa. [...] Os núcleos urbanos fundados no período colonial, tiveram apenas um sentido político de domínio territorial e escoamento de mercadorias (GODOY e BRAY, 2003, p. 186).

O Estado monárquico português do século XV tinha no imaginário religioso e no discurso doutrinador da fé empreendido pela Igreja católica seus grandes legitimadores, no que se refere a pensar o poder temporal revestido da vontade e determinação divinas. Ou seja, era o próprio Deus, através do agenciamento da Igreja, quem legitimava as ações do monarca que, em um contexto de absolutismo, se pretendia a personificação do próprio Estado. Essa origem divina do poder era o traço fundamental da monarquia portuguesa nos séculos XV e XVI.

A dinâmica da geopolítica europeia se faz sentir em terras coloniais de forma muito peculiar por ocasião do estabelecimento da União Ibérica (1580-1640), resultante das disputas sucessórias por ocasião da morte do rei dom Sebastião, o desejado, em 1578, o qual foi brevemente substituído por seu tio, o cardeal dom Henrique, por apenas dois anos. Após disputas e hesitações, a nobreza, e muito mais que ela, a grande burguesia portuguesa, aclamam Felipe II de Espanha, da casa de Habsburgo, como monarca português para ocupar o trono que havia sido declarado vago. 
A dominação Habsburgo sobre Portugal marcou efetivamente a história do Brasil, pois foi a partir desse período que se moldaram inúmeras instituições do país e deu-se forma à sua pré-configuração territorial. As mudanças na política colonial trouxeram sobre o Brasil as influências referentes ao período dos três reis Felipes de Espanha. Segundo Holanda (1989) “o período dos Felipes foi um período de penetração e conquista" [...] "Desde a conquista da Paraíba em 1584 até a ocupação do Pará em 1616" [...] como consequência "ficou a 'marca' espanhola gravada na multiplicação e localização das cidades novas e na maneira pela qual se desenvolveram mais tarde". Holanda (1989), ainda afirma que "a verdadeira colonização se iniciou com a fundação de vilas e cidade em pontos privilegiados da costa brasileira, as primeiras ligadas à iniciativa dos donatários e as últimas erigidas pela ação direta da administração portuguesa".

Moraes (2000) destaca a ausência deste período referente à unificação das Coroas ibéricas, nas análises sobre a produção territorial do Brasil afirmando que, o período felipino quase desaparece da historiografia, preocupada basicamente com a afirmação de uma identidade nacional. A crítica a esta ênfase da afirmação de uma identidade nacional, segundo o autor, faz com que a dimensão espacial seja desconsiderada das análises de história econômica, onde o fator econômico-produtivo passa a ser tomado quase que isoladamente, como a causa principal de toda a motivação da empreitada colonial. Moraes, ao fazer a análise da história da formação colonial brasileira traz à tona a dimensão espacial, considerando-a fundamental em todo o processo. O território brasileiro se configura forçosamente pela presença do colonizador que ocupa e qualifica a colônia como um espaço subordinado dentro de um jogo de interesses. Desta forma, para Moraes (2000), é válido utilizar uma leitura geográfica da história colonial do Brasil, já que um dos objetivos expressos da Coroa era manter a soberania de Portugal sobre suas possessões.

Num primeiro momento, o interesse de ocupar o espaço da colônia não se dá motivado pela produção ou exploração de produtos e matérias primas, mas por tratar-se de um espaço de localização estratégica entre rotas de comércio já conhecidas e outras que poderiam se estabelecer a partir da descoberta de novas riquezas como ouro, prata e pedras preciosas. Assim, a motivação principal da ocupação do espaço da colônia seria a do efetivo controle territorial, sendo esta ação caracterizada por apresentar um viés 
fortemente geopolítico. Desta forma, a idéia da apropriação de uma riqueza pré existente não é válida, pelo contrário, ao colonizador coube investir capitais na colônia para possível retorno futuro (MORAES, 2001, p.108). Uma exploração econômica significativa só começa a se desenvolver aproximadamente em finais do século XVI com a produção de açúcar no território. Essa economia foi a responsável pelo assentamento de fazendas inicialmente nas zonas costeiras do litoral do Nordeste e mais tarde no interior.

É neste emaranhado da teia geopolítica e econômica que, em cinco de agosto do ano de mil quinhentos e oitenta e cinco, foi fundada, por ordem Del Rey, a terceira cidade ultramarina na América, a Cidade Real de Nossa Senhora das Neves. O nome escolhido se deve à santa católica do dia da fundação, denominação motivada pela união entre o estado monarca e a Igreja católica. Mas esta seria dinâmica também no que concerne à sua nomenclatura. Cerca de três meses depois, em 29 de outubro do mesmo ano passa a chamar-se Felipéia de Nossa Senhora das Neves em homenagem ao rei da Espanha D. Felipe II.

Outra mudança ocorreu durante o período em que os holandeses conquistaram a cidade em 1634, quando em 26 de dezembro passou a ser denominada de Frederikstadt. O nome Parahyba passa a ser atribuído à cidade em 01 de fevereiro de 1654 quando da expulsão dos holandeses e João Pessoa em 04 de setembro de 1930. (RODRIGUEZ e DROULERS, 1981).

O sítio urbano inicial da cidade foi erigido numa colina à margem direita do rio Sanhauá, num local afastado da costa. Esta localização foi intencionalmente pensada em função da defesa contra as possíveis e frequentes invasões, pois ironicamente era preciso defender de invasões o território invadido dos nativos. O rio por muito tempo acabou exercendo a função de elo com o interior, como um canal de integração, a partir do qual era possível viabilizar o comércio dos derivados da cultura da cana-de-açúcar. Os morros em detrimento das planícies, eram as escolhas preferenciais dos portugueses quando se tratava de estabelecer as localizações das cidades a serem fundadas aqui no Brasil, por questões mais de defesa do que praticidade. Neste sentido, Santos (1988, p. 39) afirma que "para as finalidades que perseguiam, foram, aliás, bastante inteligentes. Rio e Salvador são para ninguém botar defeito em matéria de bom aproveitamento de um suporte físico complicado". 
Para este Estado, pautado na centralização de um poder absolutista e autoritário, elementos como defesa e controle eram metas importantíssimas no tocante à escolha deste tipo de terreno que, no caso da área escolhida para a fundação da cidade de Nossa Senhora das neves, terminou por dividi-la em duas áreas distintas: a cidade baixa ou Varadouro e a cidade alta. Estas duas áreas se diferenciavam entre si, à época, não só nos aspectos referentes às características físicas e geomorfológicas de sua localização, como também pelas funções, dentro do quadro social, político e econômico a que lhes foram designadas.

O estado monárquico e a Igreja, separados da colônia pelo Atlântico, precisavam desenvolver mecanismos que os tornassem presentes no dia a dia da vida colonial. Para isso, inúmeros elementos simbólicos são usados, a começar pela disposição espacial de construções de órgãos administrativos, religiosos e residências de alto padrão que, no caso da cidade de Nossa Senhora das Neves, foram erguidos na parte mais alta, de onde pudesse simbolicamente ser vistos por todos e a todos ver. Deus e o Rei oram por nós e olham para nós. Não por acaso a sede do poder temporal do estado e do poder divino da Igreja se presentificava do alto.

Aquilo que se destinava às atividades mais mundanas como as ligadas ao comércio, alfândegas e portos foram abrigadas em edificações erguidas na parte baixa da cidade, onde estaria sob o atento olhar de Deus e do Rei. Assim, toda a economia estava sob a vigilância permanente.

Este aspecto do baixo e do alto quando do estabelecimento das cidades é uma característica marcante nas cidades portuguesas construídas na costa durante os séculos XV e XVI, caracterizadas geralmente por traçados urbanos que apresentam semelhanças, com grandes áreas (largos) e praças localizadas à frente dos principais prédios públicos como a casa de câmara, a casa de misericórdia com o hospital e as Igrejas. Frequentemente estas construções estavam localizadas em pontos estratégicos de visão. (MARTINS, 2011)

Ao contrário do que se possa supor, a formação das cidades coloniais brasileiras nada tem de espontaneísmo. Os portugueses trouxeram regras claras de organização dos elementos espaciais, definindo e separando o público do privado. Organizando hierarquicamente a separação das terras particulares e doadas por ordem de importância e interesse, separando-as de outras destinadas às necessidades comuns e coletivas. Muitas cidades coloniais brasileiras já existiam previamente na forma de traçados e plantas e 
“cruzaram o Atlântico sob a forma de 'riscos' [...] e regulamentos que ordenavam a boa disposição espacial, o abastecimento e a defesa, muito antes que se lançasse sua pedra fundamental" (SANTOS, 1988, p. 40).

No caso da cidade de João Pessoa a Igreja foi muito eficaz em assinalar espacialmente seu poder de forma muito simbólica e emblemática. A começar pelo primeiro nome dado à cidade que se baseou numa prática muito realizada que era de adotar o nome do santo do dia, no caso, a santa.

É notória a relação entre a toponímia e o estabelecimento do poder sobre um lugar. O batismo de um lugar através de um topônimo seria um meio de propagação do ideário do nomeador, lugar este que efetivamente estaria ligado ao seu poder político e econômico. Assim, diferentemente de outros signos da língua, o signo toponímico apresenta um caráter intencional, ou seja, existem razões que fazem com que o falante escolha um determinado nome para um lugar. Segundo Siqueira (2011) as razões são decisivas para nomear um lugar e "constituem condição sinequa non para o ato de designação dos lugares (topoi) do mundo." Assim, a nomeação de lugares se faz de maneira particularizada das demais categorias de objetos e, diferentemente, segue procedimentos que se originam a partir de acontecimentos históricos, sociais e culturais.

Neste sentido, Kantor (2009) em seus estudos indica as dimensões geopolíticas da toponímia a partir da leitura de registros de mapas antigos. Segundo a autora, em 1609 a Companhia das Índias Orientais contesta a legitimidade da posse de terras portuguesas e indica uma revisão nos critérios de posse das terras recém descobertas. Uma nova condição para a titularidade das terras seria o fato de que "a soberania só poderia se exercida com a ocupação efetiva do território".

Este embate jurídico promovido pelo advogado da Companhia das Índias foi vencido por Portugal através das evidências toponímicas existentes em mapas impressos. Deste modo, segundo Kantor (2009, p. 40), “foi justamente a partir da segunda metade do século XVII que a reivindicação de posse com base na nomeação dos territórios passou a ser invocada com maior frequência nos tribunais europeus". Esta informação nos leva a compreender o porquê de a cidade de Nossa Senhora das Neves, depois de batizada em 5 de agosto, teve seu nome modificado para Filipéia de Nossa Senhora das Neves em 29 de outubro, cerca de 85 dias depois. 
Percebemos, portanto, que além da toponímia, a Igreja marcou sua ideologia simbolicamente de outras formas no espaço da cidade, inclusive pela tentativa de desenvolver sensibilidades que fizessem com que as pessoas se sentissem ligadas e submissas ao seu poder. Ao imprimir simbolicamente, nos espaços e no cotidiano das pessoas, essas sensibilidades, a disciplina cristã tornar-se-ia mais eficaz. Afinal, um aspecto basilar do imaginário cristão é desenvolver nos fiéis a capacidade de subjugar sua natureza por meio do disciplinamento espiritual da natureza humana. Ou seja, um ato constante de autodisciplina para vencer o mundo, o pecado e livrar-se da condenação eterna.

A Igreja procura fazer-se presente na vida das pessoas de todas as formas possíveis e isto serve também para a forma como o espaço onde elas vivem há de ser formatado, ordenado e regulado. No tocante à formação da cidade de Nossa Senhora das Neves, como em outras cidades, verifica-se que as congregações religiosas desenvolvem um papel importante na forma como se concebe a construção das cidades, onde é comum se perceber que, na morfologia urbana dos dois primeiros séculos de existência, eram os edifícios religiosos as construções que se destacavam (MAIA, 2000).

Não por acaso, alguns autores dão conta da estreita relação entre as ordens religiosas e os senhores de terras na cidade de Nossa Senhora das Neves, com inúmeras doações de terras de parte dos senhores para o patrimônio da Igreja. Além dessas doações é sabido que, à época da colonização, a Igreja recebeu da Coroa lotes de terras tanto nas áreas costeiras, como também no interior, constituindo-se como uma das grandes donatárias de terras por toda a capitania (MAIA, 2000; CHAGAS, 2004).

Com interferências como estas a Igreja exerceu um papel de extrema influência durante a conformação urbana da cidade. A disposição dos prédios sacros construídos na época colonial em João Pessoa é bastante significativa e evidencia o poder clerical também no tocante à determinação do arranjo espacial da cidade, assim como no controle moral e no estabelecimento das normas de conduta e de comportamento dos moradores da cidade (CHAGAS, 2004).

A inscrições da fé católica não eram a apenas imaginadas e subjetivadas eram também aferidas de forma objetiva através de marcas como a que havia impressa no chão da área inicial da cidade atestando a presença da Igreja e de tratar-se de um território por ela tutelado. 


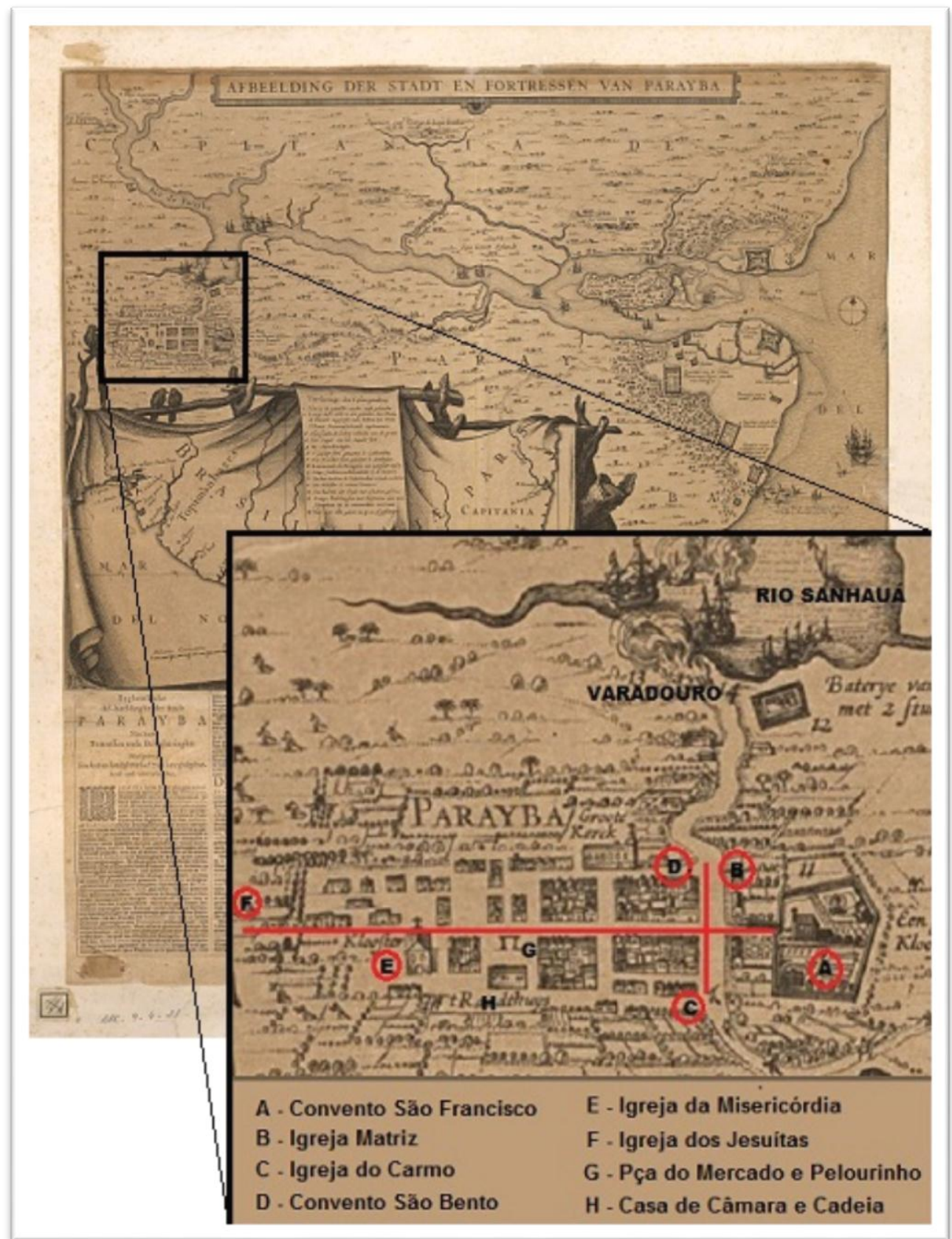

Mapa 1 - Mapa "Afbeeldingder stadt en fortressen van Parayba" de Nicolaes Visscher (1635). Adaptado pela autora. Fonte: Acervo digital da Biblioteca Nacional

Verificamos a objetividade das linhas eclesiásticas na formatação do espaço ao observar na figura do Mapa 1 que, uma cruz é formada quando se traça uma linha ligando os prédios de cada ordem religiosa presente na cidade. De norte a sul temos o convento de São Francisco, passando pela Igreja da Misericórdia, até chegar à Igreja dos Jesuítas. De leste a oeste, o traçado vai da Igreja do Carmo até o outro extremo, onde estão localizados a Igreja da Matriz e o convento de São Bento (MAIA, 2000; MARTINS, 2011; CHAGAS, 2004). 
Tal disposição está inevitavelmente relacionada à disciplina como vigilância e controles efetivos sob os quais viviam as cidades e vilas, especialmente se considerarmos às questões voltadas à produção, uma vez que nada podiam produzir a não ser o que fosse de interesse e exigência da Coroa. O que implica dizer que não poderiam ser produzidos no Brasil bens e serviços que pudessem concorrer com os metropolitanos. Em 1704, por exemplo, foi expressamente proibida a indústria do sal na Paraíba, como também havia a proibição de realizar a salga do gado e de peixes. Além disso, os governadores deviam promover o consumo de todos os produtos do Reino como: vinhos, sal, azeite e manufaturas (RODRIGUEZ, 1980).

A formatação do espaço, de suas silhuetas e de sua dinâmica, se faz dentro desse esforço por disciplinar a vida das pessoas, o que não era um privilégio do elemento clerical. A necessidade de disciplinamento e ordenação das relações sociopolíticas não era de forma alguma negligenciada. Neste sentido, não tardou para que mentores políticos da Coroa percebessem

(...) com inteligência, o quanto avenidas, palácios e monumentos contribuem para definir o novo mundo de relações sociais. Há um grande esforço disciplinador que, começando das cidadelas dos poderosos, chega, em trezentos anos, a se estender a cidades inteiras, tornando-as ao mesmo tempo, bonitas e "transparentes". As capitais são usadas como espelhos didáticos que servem a seus próprios cidadãos, à sociedade nacional e a certos objetivos controladores do Estado para a utilização interna e externa (Santos, 1988, p. 40)

No tocante aos primeiros passos da marcha do povoamento, as terras que hoje são conhecidas como paraibanas, foram alvo de intensas disputas entre franceses e portugueses, envolvendo, claro, os legítimos habitantes da terra, as populações indígenas, mais especificamente os potiguara e tabajara. Entre 1574 - quando chegou à foz do rio Sanhauá, a primeira expedição de conquista do território ao norte da Capitania de Itamaracá - e 1585, quando é firmada a paz com os Tabajara (marco da conquista do território e da vitória sobre os franceses e da formação da Capitania da Parahyba), foram quatro expedições $(1574,1582,1584$ e 1585) e um ensaio de contato "diplomático" (1578). Processo marcado por intensos conflitos e um histórico de guerras sangrentas que envolveriam os próprios nativos Potiguara e Tabajara. Índios dos quais se utilizaram os europeus, franceses e portugueses, a partir da velha tática, tão conhecida pelos primeiros povoadores europeus da terra, de dividir para conquistar, explorando o ódio tradicional existente entre diferentes grupos indígenas para tirar vantagens. E assim o fizeram ao 
incentivar as desavenças entre os nativos para usá-los como guerreiros de uma causa que não lhes pertencia e não lhes favorecia (GONÇALVES, 2007).

Ao passo que foi se estabelecendo a presença portuguesa no litoral paraibano, o território do povoamento de Nossa Senhora das Neves foi sendo ocupado e os nativos que o habitavam desde os tempos pré-cabralinos foram perdendo espaço para que a área pudesse compor o projeto de concessão de terras implementado pelo rei de Portugal. Segundo Gonçalves,

Parte do território do que viria a ser a Capitania Real da Paraíba, especificamente área situada entre o rio Goiana, ao sul, e a baía da Traição, ao norte, que correspondia a cerca de 23 léguas, foi desmembrada da Capitania de Itamaracá. $\mathrm{Na}$ época em que se processaram as primeiras expedições de conquista do rio Paraíba, no início dos anos setenta, essa faixa de terra, com exceção da região localizada às margens do rio Goiana, permanecia praticamente despovoada pelos portugueses. Era terra dos Potiguara e porto dos franceses, mercadores de pau-brasil, seus aliados (GONÇALVES, 2007, p 23)

A fundação da cidade de Nossa Senhora das Neves fez parte da luta pela conquista do Nordeste e do Norte, empreendida durante o período dos Felipes de Espanha, [...] "esta conquista foi feita aos franceses e ao mesmo tempo aos índios chamados "bárbaros", muitas vezes aliados dos franceses ou confederados e estimulados por estes" [...] "os franceses eram, na verdade, inimigo muito mais sério e onipresente do que se pôde supor" (HOLANDA, 1989).

Sobre a ocupação e divisão do território indígena da cidade entre os colonizadores que muitas terras foram doadas em sesmarias aos portugueses que possuíam meios financeiros para colaborar no projeto colonizador.

A posse das terras, ditas como devolutas, oficialmente se dava por meio de concessão, "via autorização da corte portuguesa ou de seus representantes em cada capitania" (CHAGAS, 2000), que era concedida aos solicitantes a partir de pedido para a sua ocupação. Esta prática de concessão de terras aos fidalgos da pequena nobreza passou a ser parte da política de colonização em vista da escassez de recursos da Coroa para empreender a colonização da colônia. Aqueles que obtinham parcelas se comprometiam a arcar com investimentos e despesas nas melhorias gerais, como aberturas de estradas, vias de circulação e pontes. 
O estabelecimento do povoamento garantido pela fixação definitiva dos brancos na terra se deu em meio ao desgaste conjuntural, sobretudo vivenciado pela metrópole motivado por problemas financeiros e militares, capitaneado pela revolta dos Países Baixos. Além da exacerbação da concorrência das outras nações europeias que também tentavam inserir-se nas relações de colonização com o Novo Mundo, tanto pela posse territorial, como através de práticas mercantis ilícitas, tais quais, o corso e a pirataria. Neste contexto, a negligência e a falta de investimentos estatais necessários para que se consolidasse rapidamente a conquista do território, por sua vez, não só favoreceu, mas tornou indispensável a participação da iniciativa privada na empresa colonial, o que apesar de tudo, era economicamente muito rentável mesmo diante da conjuntura política e militar externa, principalmente no que se refere ao mercado do açúcar na Europa. Não por acaso, o final do século XVI e as décadas iniciais do XVII marcaram um amplo período de valorização do açúcar no mercado internacional, o que fazia com que o interesse daqueles que já eram parte da empresa açucareira (seja como mercadores, financiadores, plantadores de cana ou produtores de açúcar) só aumentasse juntamente com sua lucratividade (GONÇALVES, 2007).

Claro que este povoamento não se deu de forma harmoniosa no tocante à ocupação de espaços, mesmo porque para que o colonizador pudesse se estabelecer no território teria que de alguma forma lidar com a presença dos nativos que se viram expropriados de sua terra na medida em que a colonização era pouco a pouco estabelecida.

As áreas do entorno da cidade de Nossa Senhora das Neves foram sendo apropriadas por intermédio de concessões de terras que faziam parte do plano colonizador de Portugal. Com isto, os índios que ali viviam, antes da chegada dos colonizadores, foram perdendo o espaço necessário à manutenção de sua sobrevivência e seu modo de vida. Nem mesmo o fato de as primeiras expedições portuguesas enviadas à costa brasileira ainda em 1501, já darem conta da presença dos potiguara que "senhoravam a costa por 400 léguas entre a Paraíba e o Maranhão", segundo a carta de 1549, enviada ao rei de Portugal por Gonçalo Coelho que denominava a referida costa como "Costa dos Potiguaras" (MOONEN e MAIA, 2008) foi suficiente para garantir as condições mínimas de sua população no território por muito tempo. É possível dizermos, inclusive, que nem mesmo a intervenção da Igreja foi eficaz neste sentido. 
A partir das Bulas Papais, de 1537, duas determinações da igreja inaugurariam uma nova fase na condição do índio perante o colonizador. A primeira considerava a racionalidade do indígena e a segunda proibia a sua escravização, determinação que tinha o intuito principal de submetê-los à catequese. De acordo com esta determinação algumas Leis Régias foram elaboradas para garantir aos índios “bons tratos”. De acordo com Moonen e Maia (2008, p. 25), “em 1587, sob o domínio da Coroa Espanhola, Filipe II (I de Portugal) determinou que se desse liberdade aos índios e terras para seu sustento, proporcionando o início da proteção que a Coroa daria à Igreja no seu trabalho missionário com os índios [...].” Isso implicava também na tentativa, por parte do reino espanhol, de garantir a posse legal da terra, o que, por seu turno, era mola-mestra de inúmeros conflitos que obrigaram os índios a empreenderem lutas de resistência em defesa da posse de um território que deveria ser seu por direito.

Nesse sentido, ao analisar documentos holandeses da época da ocupação da Paraíba Moonen e Maia (2008) destacam que os portugueses continuavam a oprimir os índios e a fazê-los de escravos, a despeito de todas as leis já promulgadas que lhes garantiam direitos à posse de terras e liberdade. Esta relação conturbada entre os colonizadores e os índios pela apropriação de terras pode ser deduzida também através do conteúdo de parte da Carta Régia de 17 de janeiro de 1671 proibindo os sesmeiros "se tornassem senhores das aldeias dos índios, existentes no districto das sesmarias, passando-se a commetter o excesso de lh'as tomarem, como também as terras que lhes pertenciam e se faziam necessárias para a cultura e sustento de suas casas e famílias" (TAVARES, 1982, p. 51).

Apesar de toda legislação e normas exigindo que fosse dada garantia de posse das terras indígenas, estes eram frequentemente desrespeitados, o que resultava em lutas que acabavam por empurrar, pouco a pouco, a presença indígena para as áreas mais afastadas da província. No decorrer do século XVI, a Coroa Portuguesa, na tentativa de conquistar a Parahyba, se empenhou, deliberadamente, em submeter os Potiguara. É possível dizer que este empenho perdurou por muitos anos, camuflado sob outras formas de persuasão, como a criação dos aldeamentos missionários que tinham como meta catequisar e "domesticar", o que nada mais era, do que desenvolver mecanismo de controle e disciplinamento sobre os índios (MOONEN e MAIA, 2008). Essa luta pela terra terminou a impingir os Potiguara ao distanciamento para além do rio Paraíba, em direção ao norte, para uma área localizada entre os rios Mamanguape e Camaratuba. 
Estudo mais recente sobre os Potiguara desta área, como o de Marques (2009), ao analisar o processo de construção do território e da territorialidade étnica dos Potiguara da aldeia Três Rios, afirma que seus traços culturais (já considerados em extinção) estão sendo re-atualizados como forma de comprovação da identidade étnica desse povo. Estudos anteriores, segundo a autora, apontaram uma tendência de desaparecimento dos Potiguaras, no entanto, ela pontua que "o fim dos Potiguaras não aconteceu como previsto, mas presenciamos nesse momento 'o renascimento' desse grupo, através das práticas de retomadas dos territórios tradicionais" (MARQUES, 2009, p. 200) Mesmo diante de semelhantes retomadas e reafirmações de territórios e de "re-atualizações" de identidades étnicas, destacamos que o resgate é pequeno diante da grandeza da perda implementada.

Durante o período inicial de instalação da cidade a Coroa Portuguesa empreendeu as primeiras mudanças significativas no espaço local com a construção de casas de moradias, prédios públicos, igrejas e engenhos, como também de caminhos de circulação. Essas modificações efetuadas simbolizam os primeiros contornos daquilo que vai se desenvolver no futuro como um espaço eminentemente urbano. No período colonial a principal área ocupada da cidade ficava no entorno do rio Sanhauá, mais precisamente na área denominada de Varadouro, e na parte alta da cidade, localizada na encosta à margem direita do rio.

O Centro Histórico, com sua dinâmica econômica e cultural, permaneceu até o século XIX como principal núcleo urbanizado da cidade, que tinha como um dos fatores limitantes de sua expansão uma área alagadiça, denominada de lagoa do Irerê, localizada à leste da cidade. O impedimento para o crescimento da cidade em outras direções se dava porque, segundo Maia (2002), havia limitações físicas como a presença dos vales dos rios Paraíba-Sanhauá, com seus amplos mangues a noroeste, além do vale do rio Jaguaribe e da reserva da Mata do Buraquinho, localizados à sudeste (MAIA, 2002).

A título de uma conclusão prévia, podemos dizer que foi a colonização lusohispânica que inventou e gerou a cidade de João Pessoa. Com isso, deu-lhe a sua forma urbana inicial, bem como lhe designou as funções dentro do quadro das relações précapitalistas de produção da época. Neste empreendimento, os poderes atrelados dos senhores de engenho e da Igreja trabalharam de forma a produzir uma cidade que assegurasse a efetiva posse e ocupação do território, e que, ao mesmo tempo, garantisse 
também a manutenção local do poderio econômico e, por que não dizer, político, dos senhores das terras (MORAES, 2000).

Neste sentido, aos considerarmos às problematizações dos chamados fatos urbanos no caso latino-americano é preciso considerar que as cidades latino-americanas se estabelecem a serviço das relações internacionais com os países evoluídos e à serviço de uma colonização que tinha como objetivo a expansão agrícola e mineradora, responsáveis pelo comércio que alimentava a vida urbana. Essas atividades datam de um período anterior à Revolução Industrial, num contexto em que a insuficiência de meios técnicos era fator limitante da produtividade. Até então, a organização do espaço efetuava-se através de meios não mecânicos que implementavam um ritmo não acelerado nas transformações (SANTOS, 1982, p. 13). Deste modo, a cidade de João Pessoa surge, então, de um processo complexo de relações levado a cabo desde a colonização, que a engendrou de acordo com os vários cenários econômicos e políticos surgidos dentro das relações capitalistas de produção.

Seu crescimento foi lento e sua fisionomia pouco se modifica por cerca dos três primeiros séculos. Estudos comparativos entre mapas portugueses e holandeses dão conta de que, em aproximadamente dez anos de presença holandesa na Parahyba, não houve uma modificação nem em termos urbanísticos, nem na tipologia das edificações, como aconteceu em Recife (MARTINS, 2011). Durante o século XVIII houve a anexação da capitania da Parahyba à de Pernambuco, fato que a tornou subordinada política e financeiramente de 1755 a 1799. A estagnação atribuída à Parahyba parece estar relacionada ao pouco controle sobre à dinâmica das práticas comerciais quando, por exemplo, a área considerada como Brejo Parahybano foi um importante produtor e fornecedor de mercadorias. Neste período, ao mesmo tempo em que esta área se apresentava produtiva, acontecia um escoamento ilegal de produtos por vias dos sertões para o Rio Grande do Norte e Pernambuco, além de desvios para o Recife e daí para o mercado externo (FERNANDES, 2008).

Por outro lado, politicamente a anexação trouxe uma dependência formal e legal que freava sobremaneira o desenvolvimento da Parahyba, principalmente no que diz respeito ao repasse dos recursos já que, ao invés destes serem feitos diretamente pela Coroa, neste contexto isto se dava via capitania de Pernambuco. O fato é que a anexação fez com que houvesse uma redução nos custos do escoamento dos produtos da capitania 
da Parahyba, pois eliminava o pagamento das taxas alfandegárias nos limites fronteiriços entre as capitanias, além de eliminar a necessidade de realização do contrabando. Aquilo que era produzido internamente não era escoado diretamente gerando outro ônus à economia local visto que os produtos passaram a ser escoados a partir do porto de Recife:

Para piorar a situação, os produtos exportados da Paraíba (açúcar, couro curtido, fumo, algodão, entre outros) saíam diretamente do porto do Recife, gerando um aumento na arrecadação do dízimo da alfândega dos portos pernambucanos. Até mesmo as boiadas que vinham do sertão, passavam por Vila Nova da Rainha (atual Campina Grande) e seguiam para serem comercializadas nas vilas de Goiana e Igarassú, em Pernambuco. A concorrência com o mercado de Pernambuco era desleal (MARIANO, 2005, p. 5).

No decorrer do século XVIII problemas na economia de exportação do açúcar fizeram com que houvesse muitos prejuízos financeiros para a capitania da Parahyba. Neste mesmo período, aproximadamente em meados do século, houve a interiorização de algumas outras atividades como criação de gado e plantações de gêneros como o milho, feijão e arroz, que fez com que a atividade produtiva se distanciasse ainda mais da capitania. Com essa maior interiorização das atividades econômico-produtivas, a cidade continuou se mantendo apenas por meio de atividades voltadas ao comércio de importação e exportação, além de outras referentes à parte administrativa.

Deste modo, foi registrada, nas duas primeiras décadas do século XIX, uma monotonia econômica e social na cidade da Parahyba que refletiu em seus aspectos urbanos, pois até os três primeiros séculos de sua fundação não ultrapassou os limites iniciais, das margens do rio Sanhauá à cidade alta propriamente dita. Segundo Maia (2000) poucas eram as edificações, destacando-se as religiosas e o Palácio do Governo (antigo convento dos jesuítas) e é com essa característica de pouco desenvolvimento em suas feições urbanas que a Parahyba adentra o século XIX. Rodriguez (1981) destaca que, no início desse século, a Parahyba apresentava uma população de 3.000 habitantes e por volta de meados do século contava com 9.000 moradores, enquanto que a cidade de Recife já contava com 46.000 habitantes em 1837.

Na Paraíba, é evidente que o contexto econômico e social que vai possibilitar as mudanças na passagem do século XIX para o XX está ligado à acontecimentos como a Abolição de 1888 e a Proclamação da República em 1889. Nesse momento ocorre, na Parahyba, a transição dos engenhos produtores de açúcar para usinas, marcada pela 
substituição das técnicas arcaicas como a tração a partir das rodas d'água e dos bois para fontes de força movidas à lenha. Maia (2000) traz uma citação em que um senhor de engenho pernambucano descreve a sua percepção deste momento de transição, muito elucidativa deste período. Segundo ele

O homem da cidade comprou a usina e comprou as terras. Com este utilitarismo comercial e as suas minucias de "deve e haver", de "lucros e perdas", com esse espírito de detalhe do homem de negócios, que investiga inteligentemente tudo e tudo anota e aproveita, e para aumentar a zona da cultura, invadiu com a lavoura da cana todos os recantos dos engenhos. Valendo-se, para sua defesa, de uma ilusória vantagem de salário, tomou, por via de regra, os pequenos sítios de mandiocas e das outras lavouras secundárias do pobre. Este deixou de cultivar o trato da terra que, ordinariamente, a complacência e o espírito de equidade do Senhor de engenho antigo lhe outorgavam. Deixou os engenhos e passou a residir de preferência nos povoados e cidades do interior, vivendo exclusivamente do salário ilusoriamente melhorado (BELLO, 1938 apud MAIA, 2000, p. 90).

Ainda de acordo com a autora, "na Paraíba, como em todo litoral nordestino, não é a instalação das fazendas de café, mas a passagem do engenho para a usina de açúcar que vai marcar as alterações sócio-econômicas no final do século XIX e início do século XX” (MAIA, 2000, p. 90). A classe possuidora dos meios da produção, agora se transfere para a cidade mudando suas feições através das melhorias implementadas em suas casas que agora abrigavam uma "nova classe" digna de um novo status. Neste processo vão surgindo, na cidade, residências de padrão alto, denominadas de casarões, com ampliação nos tamanhos e com características mais luxuosas. Possuir um casarão evidenciava a riqueza econômica e simbolizava o prestígio do senhor de engenho. Ainda segundo Maia (2000, p. 71), “esses casarões, pertencentes majoritariamente às famílias dos proprietários de usinas de açúcar, vão compor, juntamente com os templos religiosos e as sedes de órgãos públicos, os maiores destaques no conjunto de edificações da cidade".

No entanto, apesar dessas mudanças na aparência geral da cidade com a construção dos casarões, a cidade da Parahyba no final do Século XIX e início do século XX ainda se resumia à cidade baixa e à cidade alta. Suas feições ainda eram características de uma cidade colonial, com muitas casas modestas e poucas ruas com calçamento, abastecimento de água precário, assim como também os serviços de saneamento.

\section{2 - Novos olhares sobre a cidade}


A Parahyba, ainda uma pequena cidade, adentra o século XX em meio ao turbilhão de acontecimentos e mudanças que caracterizou este período de transição. No contexto mundial, mais especificamente europeu, no final do século XIX os problemas sanitários das metrópoles urbanas dos países industrializados chegara a tal ponto crítico que foram necessárias intervenções urbanas drásticas, de caráter muitas vezes arbitrário, para resolvê-los. Estas reformas fundamentadas em preocupações higienistas terminaram por influir na ampliação e na redefinição dos limites de muitas cidades brasileiras. Este princípio higienista como forma de pensamento, toma corpo com o avanço das descobertas científicas, se legitima, assumindo um discurso que penetra nos mais diversos segmentos da sociedade, interferindo e modificando bruscamente o espaço, assim como o modo de vida das pessoas.

O Rio de Janeiro inaugura, no Brasil, esse processo através da transformação de seu cenário urbano seguindo o modelo europeu vigente, mais especificamente o modelo parisiense de progresso e modernização da vida urbana. Sede da República à época, o Rio de Janeiro se transforma em exemplo a ser seguido. Neste caminho, no Nordeste, a cidade de Recife também implementa reformas semelhantes, assim como a Parahyba, em menor proporção. Conforme Chagas (2004)

A transferência dos proprietários rurais para a capital, sua incorporação
às elites e o desejo de quererem se afastar do mundo rural, visto como
antigo e atrasado, passaram a justificar a implementação dos serviços
de infra-estrutura urbana, ou seja, a modernização da cidade. Esse
processo foi resultado da renda proveniente do algodão possibilitar aos
produtores e comerciantes desse produto adquirirem uma casa na
capital e desfrutarem da modernização. Acrescente-se a isso o
fortalecimento das finanças do Estado patrocinado pelo algodão, uma
vez que, de 1900 a 1929, este foi o principal produto nas exportações
da Parahyba, superando a cana-de-açúcar e o gado [...] (CHAGAS,
2004, p. 36).

No entanto, alguns autores destacam que as primeiras intervenções urbanas aconteceram ainda no século XIX, no governo de Henrique Beaurepaire Rohan, que foi presidente da província de 1857 a 1859. Para Vidal (2004) pode-se atribuir ao seu Governo os primeiros investimentos em intervenções urbanas na cidade da Parahyba.

Nesta época muitos problemas urbanos existiam na Parahyba herdados de todo o período de recessão e pouco desenvolvimento econômico verificado desde seu início. Em meados do século XIX a cidade sofria de problemas no abastecimento de água para a população, pois poucas eram as fontes que existiam. Pinto (1977) em seu relato sobre a 
cidade nos dá uma referência das condições de saúde citando várias epidemias das quais a população foi vítima, como, varíola, febre amarela e a cólera, que atingiu a cidade em dois períodos, o primeiro em 1856 e o segundo no ano de 1862. Mariano e Mariano (2012), ao estudarem as epidemias de febre amarela e do cólera que assolaram a província da Parahyba, entre as décadas de 1850 a 1860, também citam as várias doenças que acometiam os moradores e afirmam que a província estava assolada por epidemias, como o sarampo, a disenteria e a varíola.

De acordo com Vidal (2004), por iniciativa de Henrique Beaurepaire Rohan, presidente da província (1857 - 1859), foram enviados vários relatórios ao Governo Imperial relatando a situação precária em que se encontrava a cidade neste período e solicitando recursos para que fossem realizadas obras de melhorias sanitárias. Sua primeira ação efetiva foi solicitar um levantamento para a feitura de uma planta urbana que delineasse o aspecto urbano da cidade com a representação das ruas, praças, largos, becos. Esta planta foi o primeiro passo e a base que possibilitou realizar seus planos de intervenção na cidade.

Num enfoque mais ampliado, Sá (2009), analisa até que ponto o ideário higienista foi utilizado como justificativa para a transformação ocorrida no espaço urbano de João Pessoa. Segundo a autora, estas mudanças eram justificadas nos documentos oficiais e nos jornais da época, a partir de um discurso baseado nos princípios de salubridade e higienização da cidade.

Este discurso higienista veio à calhar como uma nova forma de controle social gestado a partir de princípios do racionalismo iluminista. O poder disciplinar atuou através de leis para que se garantisse a manutenção da saúde e da ordem pública da cidade. Mariano e Mariano (2012) discutem a apropriação ideológica do tema doença compreendendo que os diferentes atores sociais, de forma própria, vivem, representam, ideologizam e metaforizam a doença. Neste sentido, a doença ultrapassaria o sentido de fenômeno natural, transformando-se em uma construção social, "permeada de valores e práticas que revelam, também, uma determinada cultura política" (MARIANO e MARIANO, 2012, p. 7).

O discurso médico foi responsável, em grande medida, pela construção do ideário relacionado às doenças, pois suas concepções acerca de como os contágios aconteciam eram alvo de muita credibilidade. Assim, as doenças passam a ser compreendidas como 
um fenômeno social resultante da "falta de moral", pobreza e outras motivações derivadas das condições socioeconômicas. Na cidade da Parahyba este ideário foi identificado por Sá (2009) e, por sua ótica, as mudanças apresentadas no tecido urbano da cidade da Parahyba foram efetivamente justificadas em documentos oficiais, assim como, no pensamento daqueles que possuíam espaço nos jornais da época para disseminar suas concepções.

Assim, os jornais da época possuíam alcance amplo no segmento da população, muito mais do que os documentos oficiais. Desta forma, compreendemos que, os documentos oficiais garantiam a legitimidade de um discurso nascido das elaborações técnicas e ideológicas da elite médica, enquanto que os jornais faziam seu papel de disseminadores do ideário higienista. Neste sentido, para Chagas

enquanto parte da elite desejava a modernização, os pobres eram
afastados das ruas centrais [...] Encarcerar os pobres e tirá-los da rua
temendo que cometessem atos violentos, ou que seus corpos
transmitissem alguma moléstia, também se constituiu uma das
respostas do processo de urbanização na cidade da Parahyba
(CHAGAS, 2004, p. 22).

A Parahyba se insere no contexto dos ajustes urbanos de acordo com as concepções do campo da sociedade e dos intelectuais da época. A articulação entre o estado e o poder econômico efetivou, através de inúmeras ações e interferências no espaço urbano, um controle social numa dimensão muito mais ampla. Através da justificativa de higienizar a cidade contra os efeitos das doenças, passaram a interferir nos costumes em nome da razão e da ciência.

A articulação entre Estado e medicina proporcionou um maior controle social e os médicos passaram a ampliar a sua atuação, antes restrita aos indivíduos e as famílias, para a normatização de espaços sociais cada vez mais amplos. Neste sentido, higienizar a cidade e os costumes era crucial para defender a "civilização", produzindo saberes, buscando legitimação e institucionalização, prescrevendo e controlando em nome da razão e da ciência. Assim, a medicina organizou serviços públicos almejando "progresso social e científico".

No Brasil os ideais de modernidade avançam com o início do Regime Republicano, fato este que impingiu mudanças estruturais, amplas e complexas, no cenário político e social. O estabelecimento do pensamento moderno significou, entre 
outras coisas, a incorporação de novos valores às antigas concepções, tendo como base princípios advindos da ciência e da razão prática. O sentimento de modernidade veio juntamente com a necessidade de negar qualquer sinal do passado colonial e imperial do país.

Esses valores são forjados de modo a ratificar e fortalecer os ideais republicanos através de uma ordem e de um progresso buscados a todo custo. A cidade passa a ser o espaço privilegiado para a prática dos novos costumes, espaço de novas concepções, onde uma vida política passa a ter sentido, ampliando a noção e o significado do espaço público. A cidade de antes se transforma adquirindo uma nova feição que se evidencia a partir dos melhoramentos que, aos poucos, vão surgindo, como serviços e equipamentos urbanos.

Na cidade da Parahyba, entre o final do século XIX e início do século XX, ainda prevaleciam os traços do Período Colonial adicionados de algumas características mais modernas acrescentadas durante o Período Imperial. Mesmo diante das mudanças com caráter mais moderno implementadas durante o Império, não foi possível eliminar muitas destas características herdadas dos períodos passados, como ruas estreitas, becos, vielas, falta de saneamento, de água encanada, de coleta de resíduos, de iluminação, para citar apenas algumas.

Naquele momento as mudanças ocorridas no meio rural com a transição dos antigos engenhos de açúcar pelas modernas usinas de açúcar, além da alta econômica proveniente da renda do algodão, refletiram de forma ampla e profunda na, até então, Parahyba do Norte. Há agora uma nova forma de viver a cidade por parte das famílias dos novos proprietários das usinas, que, ao invés de passar apenas períodos do ano nela, invertem a lógica, transferindo sua residência fixa para a cidade que, neste momento, representa tudo o que há de moderno. Esta conjuntura estimula as ações de modernização da cidade, onde estavam previstas interferências no sentido de obter um embelezamento nos moldes de um novo padrão estético.

Baseado nos ideais de modernidade começa a nascer um projeto de cidade que agora deveria seguir o modelo de cidade moderna, idealizada em contraposição à cidade antiga-rural, com suas bases fundadas nos ideais do progresso e do desenvolvimento da ciência e das tecnologias. Jornalistas, médicos e escritores, assim como os políticos se empenham por delinear através de seus textos, artigos, leis, decretos, relatórios, as feições 
desta cidade idealizada que representasse os anseios de modernidade daqueles que dominavam o cenário econômico e cultural.

Uma cidade que aliasse princípios estéticos às questões das necessidades básicas urbanas da população, como abastecimento de água tratada e esgotamento sanitário, calçamento, iluminação elétrica de ruas e casas, bem como a modernização do transporte urbano. Cabe, portanto, refletir sobre como a modernidade e suas interferências no espaço contribuíram para as mudanças na configuração urbana da cidade neste momento.

\subsection{1 - Abastecimento de água na Parahyba: a modernidade chega às torneiras}

Apesar das muitas melhorias implementadas ainda no final do século XIX, Vidal (2004) destaca o descompasso existente entre a desejada modernidade e a realidade existente na província da Parahyba no início do século XX. Neste sentido Chagas (2004) também aponta certo atraso nas melhorias necessárias para a modernização da cidade da Parahyba, afirmando que:

Demorou um pouco para que as ruas da Parahyba passassem a ser por excelência o espaço onde a modernização poderia ser percebida, vivida e contemplada. Essa nova condição esteve representada na implementação do calçamento a paralelepípedo, na instalação da luz elétrica, do bonde, da água tratada e do esgoto sanitário (CHAGAS, 2004, p. 37).

O baixo investimento realizado para as melhorias urbanas necessárias na cidade fez com que o abastecimento de água encanada viesse a ser implantado somente a partir do ano de 1912, mesmo constando reivindicações por este serviço desde 1866 (SÁ, 2009).

O primeiro sistema de abastecimento de água foi elaborado por solicitação do presidente João Lopes Machado, como salienta Nogueira (2005), e seguiu o modelo adotado pela Companhia Beberibe de Recife que consistia na captação de água de poços subterrâneos. A efetivação desta obra contemplou duas dimensões da perspectiva da modernidade, a questão de um serviço urbano básico, no caso o abastecimento de água, e a questão do embelezamento estético com a abertura da Avenida João Machado, cujas obras foram realizadas concomitantemente. 
Estas ações de modernização e embelezamento da cidade ocorreram com maior ênfase nas primeiras décadas do século XX quando foram realizadas algumas medidas de melhoramentos estéticos na cidade, aprumando a tortuosidade das ruas e nivelando a irregularidade das construções que avançavam invadindo as ruas. A cidade deveria, naquele momento, traduzir os anseios de modernidade que tomou posse de parte de sua população, através da ampliação de seus espaços públicos e de suas ruas, agora projetadas com traçados retilíneos. Com isso, de acordo com Soares (2012), por volta de 1908 a Avenida João Machado foi planejada seguindo o modelo dos "boulevards" franceses tendo sido ocupada, em toda sua extensão, por muitos casarões de alto padrão.

Nogueira (2005) indica que a abertura desta avenida é o exemplo de uma dessas ações no sentido da modernização e do ordenamento da cidade e fez parte das obras de execução do projeto do sistema de abastecimento de água idealizado e executado por Miguel Rapôso. Com 22 metros de largura por 1.350 metros de extensão, esta avenida foi projetada em linha reta ligando a estrada do Macaco (hoje av. D. Pedro II) à rua das Trincheiras e passando ao lado da atual igreja de Nossa Senhora de Lourdes. Segundo Soares (2012) desde sua abertura, em 1910, até cerca de vinte anos depois, a ocupação daquela avenida se deu, prioritariamente, por residências de alto padrão e por prédios institucionais.

Vale salientar que, no primeiro momento em que o fornecimento de água encanada se inaugura, apenas uma pequena parcela da cidade é abastecida deste serviço. Anteriormente a mesma era fornecida exclusivamente por meio de bicas, chafarizes e cacimbas $^{2}$, além de ser também obtida através dos aguadeiros ${ }^{3}$ que a transportavam em recipientes carregados por burros (VIDAL, 2004; CHAGAS, 2004).

Chagas (2004) cita um movimento contrário à modernização urbana da cidade entre os intelectuais locais influenciados por uma linha de pensamento derivada de alguns intelectuais de Pernambuco liderados por Gilberto Freyre. Este grupo, contrário ao modelo de modernização urbana, defendia que a feição colonial das cidades deveria ser preservada como forma de manter e construir a identidade nacional. Na Parahyba os

\footnotetext{
${ }^{2}$ Poços cavados até um lençol freático, muito comuns anteriormente nos quintais das casas.

${ }^{3}$ Pessoas que vendiam barris de água nas portas das casas.
} 
intelectuais locais tiveram na Revista Era Nova um importante veículo de propagação de seus ideais, tendo como importante colaborador o escritor José Lins do Rego. (CHAGAS, 2004). No entanto, a despeito das divergências ideológicas sobre a modernização urbana, as obras de implementação dos serviços continuaram a ser executadas e, aos poucos, a cidade foi incorporando novos serviços de melhorias urbanas como a implantação do serviço de energia elétrica.

\subsection{2 - Eletricidade na Parahyba: luz para as ideias, tração para as ações}

A iluminação a gás já foi um símbolo de modernidade urbana e foi introduzido no Brasil em 1850 ainda durante o Período Imperial. O Rio de Janeiro, por iniciativa do barão de Mauá, foi a primeira cidade da América do Sul a contar com este tipo de fonte energética, seguido da cidade de Recife. Em seguida, outras cidades do país também conseguiram implantar este serviço, como Salvador, Belém, Porto Alegre e São Paulo, de forma que, em 1870, todas estas já contavam com a iluminação a gás (NOGUEIRA, 2005).

Na cidade da Parahyba, desde os primeiros anos do Império até 1885, a iluminação das vias públicas era feita por lampiões alimentados por óleo de mamona. No entanto, esses lampiões existiam apenas nos pontos mais importantes da cidade e contavam com pessoas encarregadas de alimentá-los, acendê-los e apagá-los (NOGUEIRA, 2005). Segundo Vidal (2004), a precariedade na iluminação pública da cidade foi destacada por Beaurepaire Rohan em seu relatório dirigido ao Governo Imperial, em 1858, onde faz um relato detalhado da situação da cidade na época.

Diante do problema, o governo da Parahyba fez tentativas no sentido de substituir o óleo de mamona pela fonte energética mais moderna da época, como o gás canalizado. Mas, diante do insucesso nesta tentativa o governo decide, em 1885, substituir a iluminação a óleo de mamona pela iluminação a querosene. Nogueira (2005, p. 16) destaca a quantidade insuficiente destes lampiões nas ruas da cidade que, "em 1902, este número tinha sido ampliado para 246 unidades, distribuídas por 84 logradouros - o que dava uma baixíssima média por logradouro". Desta forma, podemos inferir que, quando da difusão da energia elétrica no país, em 1890, a Parahyba não apresentava uma 
iluminação satisfatória de suas vias públicas e ainda utilizava fonte energética ultrapassada.

Neste ínterim, houve uma primeira tentativa de instalação da eletricidade pelo governo da província, fato acontecido também neste ano de 1890. A iniciativa foi mal sucedida, pois a proposta definida no contrato firmado com a empresa, denominada Adriano Loureiro \& Cia., não foi viabilizada, tendo o contrato perdido a validade em 1906. Neste mesmo ano o governo abriu concorrência para empresas interessadas em instalar os serviços de iluminação elétrica na cidade, assim como a eletrificação das linhas de bondes.

As obras para a instalação do serviço de iluminação e tração elétrica tiveram início somente em 1911, quando do governo de João Lopes Machado. A energia elétrica, tão festejada na virada do século XX, só passou a fazer parte da vida dos moradores da Parahyba em 1912. Segundo Chagas (2004, p. 52), “[...] a cidade da Parahyba do Norte entrou no século XX na escuridão, iluminada por apenas 300 lampiões alimentados de azeite de mamona e querosene [...]". Em tempo, o fornecimento deste serviço viabilizou muitas outras melhorias, como a substituição dos bondes de tração animal por uma nova linha movida à tração elétrica. Esta mudança melhorou substancialmente a circulação da cidade, tanto com relação à velocidade dos bondes, quanto ao conforto dos passageiros, assim como diminuiu muito a quantidade de animais que circulavam pelas ruas e que deixavam muitos excrementos por onde passavam (VIDAL, 2004). Na Parahyba toda modernidade se dava de forma muito tardia.

\subsection{3 - E o bonde elétrico movimenta a cidade}

A instalação dos bondes elétricos na cidade da Parahyba do Norte foi um acontecimento muito importante para uma cidade que se tentava, com muita dificuldade, enquadrar nas prerrogativas de modernidade. Nogueira (2005, p. 14) destaca que, nas principais cidades do país, já em 1870, existiam bondes puxados a burros. A capital paraibana passa a contar com este tipo de transporte coletivo urbano somente em 1896, cerca de vinte e seis anos depois. Além de atrasado, este serviço de transporte só foi possível por causa da iniciativa dos próprios empreendedores paraibanos que fundaram 
uma companhia denominada Ferro-Carril Parahybana, cuja finalidade era a exploração do serviço de transporte coletivo movido à tração animal.

Inicialmente financiada e administrada por um grupo de comerciantes locais, em 1906 esta empresa passou a ser administrada pelo governo e, no processo de transferência para tração elétrica, foi repassada para a empresa ganhadora da concorrência (NOGUEIRA, 2005). A circulação dos bondes puxados a burros se restringia a ligar as ruas da Cidade Baixa ou Varadouro às áreas norte (Tambiá) e sul (Trincheiras) da cidade, passando pelas ruas Maciel Pinheiro, Barão do Triunfo, Guedes Pereira e Duque de Caxias. Aos poucos as ruas por onde trafegavam os bondes foram recebendo calçamento de paralelepípedos e a outras ruas também foi incorporada esta melhoria.

Diversos autores, a partir de fontes da historiografia paraibana, citam a escassez de recursos necessários para por em prática os serviços de melhoramentos urbanos tão esperados (CHAGAS, 2004; NOGUEIRA, 2005; VIDAL, 2004). Mesmo assim, muitas mudanças ocorreram no espaço urbano no período que marca o início do século XX até a década de 1930, ruas foram calçadas, desapropriações aconteceram para alargamento de ruas e melhoramento da circulação dos bondes, além de abrir espaço para praças e grandes largos para passeios públicos. Para o caso do calçamento das vias públicas, o governo da província, na falta de verbas para este serviço de urbanização, decretou que os proprietários de imóveis assumissem parte das despesas contribuindo com um terço do custo do calçamento que correspondesse ao trecho de sua propriedade (CHAGAS, 2004).

Enfim, com a instalação da energia elétrica na cidade houve também a conversão da tração dos bondes que serviam ao transporte da população para eletricidade. Isto melhorou muito a agilidade no deslocamento pela cidade tornando necessária ainda mais a ampliação dos espaços. Sabe-se que a primeira linha de bondes elétricos foi colocada em circulação no Rio de Janeiro em 1892 e operacionalizada pela Companhia Ferro-Carril do Jardim Botânico. Em seguida, em 1897, passa a circular em Salvador. São Paulo teve sua linha de bondes elétricos em operação no ano de 1900. Somente no século XX é que a energia elétrica passa a substituir a tração animal em outras cidades do país, em 1909 em Porto Alegre, em Natal no ano de 1911 e em Parahyba do Norte somente em 1914 (NOGUEIRA, 2005, p. 13).

A modernidade trouxe novos hábitos como a iluminação elétrica das ruas que possibilitava novas práticas sociais, como passeios à noite, conversas nas calçadas até 
mais tarde. Costumes pouco utilizados pelos moradores antes da chegada da energia elétrica. Além disso, a vida social tornou-se mais movimentada com a possibilidade de transportes mais eficientes e rápidos que facilitavam o deslocamento das pessoas ao teatro, cafés, clubes.

À medida que o espaço da cidade se amplia com novas necessidades e novos hábitos, ampliam-se também os limites de deslocamento das pessoas, com novas áreas incorporadas ao seu cotidiano Assim, no período de 1906 a 1908 foi construída uma ferrovia para ligar a cidade à praia de Tambaú com uma locomotiva movida a vapor. Esta linha partia do Sítio Cruz do Peixe, próximo ao atual Hospital Santa Isabel e, num primeiro momento (1906), fez a linha até o Sítio da Imbiribeira, nas proximidades do $1^{\circ}$ Grupamento de Engenharia. Em 1907, após complementação das obras, a linha foi ampliada até o destino da praia de Tambaú.

Esta ferrovia foi incorporada, juntamente com a antiga empresa responsável pelos bondes de tração animal, à nova empresa ganhadora da concorrência já citada para eletrificação dos transportes na Parahyba (Vidal, 2004). A abertura da Ferrovia Tambaú trouxe uma incorporação das áreas litorâneas da cidade ao facilitar o acesso das pessoas à praia. Além disso, houve o início da valorização dos sítios e chácaras localizados por toda a extensão do caminho da mesma. Coutinho (2004, p. 52) chama atenção sobre a floresta atlântica existente na área "[...] que preenchia todo espaço entre a área urbana e o litoral começava a ser devastada - primeiro para a abertura de estradas, depois servindo de combustível, na futura Usina Cruz do Peixe que traria a iluminação para a cidade". Antes da instalação desta ferrovia ${ }^{4}$, era comum parte da população veranear em praias localizadas no Distrito de Cabedelo, com esta ferrovia ampliaram-se as opções de praias acessíveis para a população que passou a frequentar a orla de Tambaú com maior frequência.

\footnotetext{
${ }^{4}$ No início do século XX as praias preferidas pelos moradores da cidade da Parahyba eram as localizadas no município de Cabedelo. Do Varadouro partiam o trem e diversas embarcações que levavam as pessoas até esse destino. Até os anos de 1920, aproximadamente, Tambaú era evitada pelos banhistas por causa da malária responsável por muitas mortes naquela área. Fato que se modifica logo após as obras de saneamento do Rio Jaguaribe (1922) que teve o seu curso desviado para que se evitassem os alagamentos muito constantes na sua foz e que era responsável pelo foco do mosquito transmissor. Com esse desvio, o Rio Jaguaribe foi ligado ao Mandacaru (LEITÃO, 1998).
} 


\subsection{4 - O jogo urbano: cartas marcadas no espaço da cidade}

A modernidade tomada como um estágio da sociedade foi resultante de um processo histórico e social que teve como consequência um desenvolvimento progressivo e irreversível nos diversos setores da sociedade. No entanto, pode-se afirmar que este desenvolvimento não aconteceu de forma igualitária por todos os lugares. Todo este processo imprimiu mudanças profundas na sociedade, no seu modo de produção e, consequentemente, no seu modo de atuar no espaço. O modo de produção capitalista, com a industrialização, muda radicalmente a relação das pessoas com o tempo e com o espaço, fato que modifica sobremaneira a configuração urbana das cidades. No Brasil, cidades como Rio de Janeiro, Recife e São Paulo inauguram esta nova tendência baseada na modernidade e fundamentada no progresso e na tecnologia que passa a imprimir no espaço uma configuração urbana mais condizente esta nova mentalidade.

Para Le Goff (2003) a consciência da modernidade nasceria a partir do sentimento de ruptura com o passado, num jogo de forças opostas entre o antigo e o moderno, onde o termo modernidade toma a forma superficial e carente do seu sentido construído historicamente para se tornar esta ruptura com um passado de forma a negá-lo quase totalmente. A modernidade assume o caráter do "novo", do "progresso", tomado como conjunto de avanços, acumulação de conhecimentos, e séries de mudanças consideradas como positivas. Segundo Le Goff (2003, p.185), “com base na herança histórica da querela entre antigos e modernos, a Revolução Industrial vai mudar radicalmente os termos da oposição do par antigo/moderno, na segunda metade do século XIX e no século XX”.

Este jogo se fez presente no processo de inauguração do caráter urbano na cidade da Parahyba. De um lado, toda a herança advinda dos períodos da Colônia e do Império que imprimiu marcas concretas no corpo da cidade, em suas ruas, casarios, pontes, largos, igrejas e monumentos. Todo um conjunto de realizações socialmente construídas no contexto de um jogo de forças político, econômico e cultural que marca sua existência de forma concreta no espaço.

Levando em conta esse conjunto de forças, que imprime movimento, produção e transformação no espaço urbano da cidade, Santos (1988) faz uma analogia entre o que acontece na cidade com o que acontece durante um jogo de cartas de baralho. Sabe-se 
que um jogo de baralho acontece entre dois ou mais opositores que dispõem cartas numa superfície e levam em conta regras pré-estabelecidas. O baralho atualmente é composto de 52 cartas divididas em conjuntos de quatro naipes (paus, ouros copas, espadas) com numeração em ordem de um a dez. Outros símbolos complementares são as imagens do valete, da dama e do rei que, sob um ponto de vista simbólico, também expressam um tipo de ordenamento.

A existência da numeração e dos naipes possibilita agrupamentos de conjuntos e subconjuntos (cartas de mesmo número, sequência de mesmo naipe) que, de acordo com a jogada, pode valer mais pontos tendo em conta as regras estabelecidas. De origem oriental, o baralho se transforma ao chegar no ocidente e vira um passatempo muito utilizado pelos europeus. De acordo com Santos (1988, p. 12) "a sociedade européia, ao jogar baralho, está 'se jogando' ou 'brincando' de repetir seu próprio desempenho [...] Cada naipe é uma classe: copas, o clero; espadas, a nobreza; ouros, a burguesia; e paus, os camponeses". Assim como um jogo de baralho, o jogo urbano se joga sobre uma superfície que é o espaço urbano da cidade e, para que isso aconteça, é necessário que existam os parceiros deste jogo, que se agrupam entre alianças e oposições.

Neste jogo os aliados se formam levando em conta posições, interesses, funções que ocupam, de acordo com os grupos e filiações a que pertençam, que poderão estar fragmentados e distribuídos dentro de três segmentos, o governo, o capital, e a população. Bem apropriada, esta metáfora serve para auxiliar na compreensão dos processos históricos, políticos e econômicos que fazem com que cada cidade tenha sua própria identidade, apesar da tendência do capitalismo de induzir à uma homogeneização dos espaços.

Na Parahyba, principalmente a partir do século XX, mesmo com caráter ainda insuficiente, muitas transformações ocorreram no aspecto urbano da cidade. Muitas das inovações tecnológicas surgidas permitiram a melhoria dos serviços urbanos e contribuíram fortemente para essas modificações da configuração urbana da cidade. Foram necessárias grandes reformas no espaço urbano para que fossem instalados os equipamentos e novos serviços mais modernos. Com isso, muitas ruas foram abertas e outras ampliadas, muitos prédios e casarões foram derrubados para dar lugar a espaços amplos e largos que acomodassem as novas pessoas e seus novos costumes e necessidades. 
Neste momento uma nova sociedade se formava a partir dos ideais de modernidade anunciados no Brasil entre os séculos XIX e XX, ideais estes advindos de um novo regime político que desestruturou a organização do poder estabelecido até então. Novas descobertas científicas e tecnológicas mexem com as ideias, pensamentos, necessidades, costumes e valores da sociedade cujas transformações implicaram também em modificações na paisagem urbana da cidade. A ordem agora era transformar a cidade que deveria tomar feições de moderna e, com isso, era necessário eliminar o seu aspecto que deveria ter como modelo a cidade de Paris. O mundo rural agora era considerado atrasado e ultrapassado, ao passo que a cidade era vista como o lugar onde imperava o novo e tudo o que era moderno.

A particularidade existente no início do processo de modernização da cidade da Parahyba foi que, ao contrário do que ocorreu na maioria das cidades brasileiras, pode-se dizer que a modernização iniciada na Parahyba foi engendrada dentro de um processo de ausência de industrialização, que possibilitou um tipo de modernização que pode ser chamada de incompleta restrita à obras de embelezamento e implantação de serviços urbanos, mesmo assim de forma pontual em lugares selecionados.

O ideário higienista esteve presente e permeou todo o processo de mudança e em diversos momentos serviu de base para a legitimação do discurso da necessidade de mudanças no traçado urbano da cidade. A necessidade de transportes mais ágeis e confortáveis do que os de tração animal, fez com que grandes modificações ocorressem no espaço urbano, além do que a velocidade dos novos bondes carecia de novas configurações no espaço que proporcionassem mais segurança aos pedestres e usuários, assim como menor tempo no percurso. Além dos bondes, outras melhorias urbanas como a implantação de serviços essenciais de água encanada e energia elétrica foram fatores que contribuíram em grande medida nas transformações da configuração espacial e no processo de urbanização da cidade da Parahyba.

Destaca-se, porém, que desde o princípio as obras de melhoramentos urbanos não chegaram perto dos bairros onde residia a classe trabalhadora da cidade. A energia elétrica, por exemplo, esteve restrita à poucas ruas da área central até cerca de 1915, quando a iluminação foi ampliada aos bairros das Trincheiras, Tambiá e Varadouro. Ainda assim, na década de 1920, segundo Chagas (2004), a cidade ainda apresentava problemas de iluminação pública com as residências populares em sua maioria sendo 
servidas de luz de candeeiros e lampiões a óleo de mamona ou querosene até a década de 1960 (CHAGAS, 2004, p. 60). Assim como os outros serviços necessários à vida urbana, como a água encanada e os transportes que também por muito tempo se limitou aos moradores da área central da cidade.

Podemos considerar que, na cidade da Parahyba, a modernidade foi confundida e reduzida praticamente às obras de serviços urbanos e embelezamento da cidade. Além disso, essa aparência de modernidade foi forjada diante da incapacidade financeira do estado, não teve outra alternativa senão a de custear inicialmente e parcialmente os serviços que achasse necessários para tornar a aparência da cidade coerente aos ares de vida moderna. Assim, foi no caso da implementação da primeira linha de bondes de tração animal, cujo inicio se deu pela iniciativa dos empresários comerciantes da cidade que fundaram uma empresa de prestação deste serviço. Outro exemplo percebido foi a solicitação do governo da província para o custeio parcial, por parte dos proprietários de residências, da pavimentação das ruas no perímetro da fachada de suas casas. Percebe-se que a modernidade forjada na cidade da Parahyba se mostrou incompleta e parcial, já que a salubridade como um dos princípios base deste ideal não foi implantada para toda a população através dos serviços urbanos básicos que demorou para ser realidade nas casas de bairros mais pobres.

Podemos inferir que, no jogo urbano, nem sempre as regras estiveram claras e equilibradas para todos, principalmente no que diz respeito aos interesses das pessoas comuns, aquelas representadas no baralho pelo naipe de paus, ou seja a classe trabalhadora. Sempre excluída das melhorias urbanas, ou deixadas por último na lista de logradouros, ruas, espaços a serem priorizados na implantação dos serviços de melhoramentos urbanos.

\section{3 - Novos desdobramentos urbanos}

Lefebvre (1999) parte da hipótese da urbanização completa da sociedade, definindo a sociedade urbana como a sociedade que nasce da industrialização, a partir do desenvolvimento e do aumento dos meios de produção que concentram e fazem proliferar também a população. Este processo de surgimento da sociedade urbana acontece simultaneamente ao processo de gestação da cidade urbana, em que "o tecido urbano 
prolifera, estende-se, corrói os resíduos de vida agrária” (LEFEBVRE, 1999, p. 17). O autor salienta que o termo "o tecido urbano" ultrapassa seu significado restrito como denominador apenas de uma cidade concreta, edificada, visível, mas designa todo o conjunto das manifestações do predomínio da cidade sobre o campo. O espaço se transforma em tecido urbano na medida em que, através dos processos técnicos, são costuradas entre si partes conjuntas da realidade social, denominada por Santos (1997), de fixos, em suas formas concretas, e de fluxos, a fluidez que possibilita a estrutura em rede. Neste sentido, sobre as muitas transformações verificadas nas cidades dentro de um curto período temporal Lefebvre (1999) designa de revolução urbana

O conjunto das transformações que a sociedade contemporânea atravessa para passar do período em que predominam as questões de crescimento e de industrialização (modelo, planificação, programação) ao período no qual a problemática urbana prevalecerá decisivamente, em que a busca das soluções e das modalidades próprias à sociedade urbana passará ao primeiro plano (LEFEBVRE, 1999, p. 19)

No processo de transformação das cidades, algumas ações são graduais, pensadas, planejadas; outras, porém, são bruscas e imediatas. Para o autor, o termo revolução urbana não traz consigo o sentido claro de uma ação violenta, no entanto, o sentido de violência não está totalmente excluído.

Diante de uma ideologia que favorecia o moderno ocorreram muitas modificações na fisionomia urbana da cidade da Parahyba entre o final do século XIX e início do XX. Vidal (2004) destaca a contribuição das ações do urbanismo cirúrgico nas transformações da cidade durante a implantação dos primeiros serviços urbanos que ocorreu entre os anos de 1910 e 1940 sob o discurso de que era necessário embelezar, sanear e circular. A modernização de seu aspecto urbano aconteceu ao mesmo tempo de outras cidades do país. Sucessivas administrações trabalharam no sentido de proporcionar a continuação do processo de modernização da cidade de forma que passasse a ter ares semelhantes ao europeu.

No entanto, em cidades como João Pessoa, as feições de modernidade que foram introduzidas com a ampliação das vias urbanas (sob a justificativa higienista) vieram à calhar diante das novas necessidades de circulação das mercadorias ocasionadas pela revolução dos transportes. 
Ao tratar dos processos urbanos em João Pessoa, Maia (2000) observa a expansão da cidade com desdobramento de seu centro. Segundo a autora, na João Pessoa moderna a centralidade muda incorporando a cidade histórica. Neste sentido, Vitte (2003) afirma que todas essas mudanças que interferem e alteram o espaço urbano induzindo-o à novas formas e funções, acontecem sobre um espaço herdado, que é resultante de uma história local com características próprias e de um espaço projetado (que pode ser planejado, ou não) mas certamente transformado. Esta particularidade verificada na cidade faz com que o novo modelo de paisagem construída conviva com as velhas formas, já que a chegada das novas formas não é um fator determinante que garanta a exclusão das antigas. Durante longo período podem conviver na mesma paisagem antigas e modernas estruturas. $\mathrm{O}$ Centro Histórico da cidade da Parahyba é bem marcante neste sentido, apresentando características de diferentes períodos históricos, percebidas, por exemplo, em registros arquitetônicos de prédios que datam desde o período colonial, a exemplares que marcam a entrada da cidade na modernidade até os tempos atuais.

\subsection{1 - A década de 1920 e a importância de Saturnino de Brito}

Se já havia, na cidade, os símbolos urbanos da modernidade, água encanada, luz elétrica, bondes elétricos, o que marca as transformações na paisagem urbana da Parahyba a partir da década de 1920 ?

Ao mesmo tempo em que a antiga estrutura urbana herdada das várias interferências coloniais e imperiais eram adaptadas para receber as novas tecnologias de transportes e de serviços urbanos, acontecia a expansão da cidade em direção às áreas além de seu núcleo central original.

Já no período republicano, outras diferentes questões vieram a interferir e a gerar mudanças no traçado urbano da cidade. No final do século XIX foram verificadas expansões na área urbana da cidade devido à chegada de muitas famílias vindas do interior fugindo da seca. Com a falta de recursos por parte do estado não restava outra alternativa para estas pessoas senão a de fugir para a cidade em busca de trabalho e melhores condições de vida. $\mathrm{O}$ aumento da população da cidade forçou o crescimento da mesma a ultrapassar os antigos limites: no sentido sul, a Igreja Nossa Senhora de Lourdes; a norte, a Bica do Tambiá; a leste, um caminho fazia a ligação da cidade até o sítio Cruz do Peixe (COUTINHO, 2004). 
Segundo Vidal (2004) a abertura da avenida João Machado favoreceu e reforçou a tendência da expansão da cidade na direção sul. Além da abertura desta avenida, a construção da Balaustrada das trincheiras serviu; também para consolidar o surgimento do bairro de Jaguaribe, e direcionou os limites da capital mais para o sul, no sentido da cidade de Recife (COUTINHO, 2004).

O bairro de Jaguaribe fez parte da primeira expansão urbana planejada, cuja iniciativa esteve, de certo modo, vinculada e impulsionada pelas obras realizadas por volta de 1910 para a implantação do serviço de abastecimento de água (VIDAL, 2004). A princípio tratou-se de um loteamento criado pelos proprietários particulares de terras naquela área, inclusive a igreja, que alocava terrenos em troca de um pagamento conhecido como foro. O início da urbanização daquela área da cidade se deu inicialmente com casas, na sua maioria de taipa e cobertas de palha, onde residiam uma classe trabalhadora de operários, alfaiates, costureiras, sapateiros e domésticas (CHAGAS, 2004). O bairro de Jaguaribe, com seu traçado regular e ortogonal, inaugura na cidade a tendência de crescimento urbano planejado com a ocupação de grandes áreas recém incorporadas ao traçado urbano e destinadas às áreas residenciais. Esse modelo deu início ao que se tornaria o padrão de expansão urbana na capital paraibana no futuro.

O poder público empreendeu um enorme esforço no sentido de modernizar a capital paraibana, marcadamente na primeira metade do século XX. Na cidade, a partir da década de 1920, muitas mudanças foram realizadas que serviram de base e propiciaram muitas das obras de expansão urbana. Estas mudanças tiveram início ainda no governo de João Machado (1908 - 1912), o qual iniciou os fundamentos do modelo de urbanização próprio do século XX e que foi verificado também nas outras capitais do país.

O governo de Castro Pinto (1912 - 1915) deu continuidade ao processo de expansão urbana da capital paraibana quando ocorreu a primeira tentativa para que Saturnino de Brito realizasse as obras de saneamento na cidade da Parahyba. A solicitação do projeto de esgotamento da cidade ocorreu em 1913 e previa também um plano de expansão urbana, no entanto, problemas políticos impediram a realização do mesmo. Em seus projetos, Saturnino de Brito apresentava soluções inovadoras para os problemas sanitários das cidades, com a preocupação em realizar um planejamento que garantisse uma expansão racional do crescimento urbano levando em consideração também a 
topografia do terreno para facilitar o escoamento, tanto das águas pluviais, como dos esgotos sanitários.

Dentro deste projeto definido para a Parahyba por Saturnino de Brito, em 1914, estava previsto o saneamento da Lagoa dos Irerês, cuja área se tratava de um grande alagado que limitava o crescimento da cidade na direção leste. Até aquele momento o crescimento da cidade se dava predominantemente na direção sul. Vidal (2004) destaca que, na proposta de Saturnino de Brito para a cidade da Parahyba, havia uma preocupação em evitar obras cirúrgicas, em que fossem necessárias muitas demolições, como forma de se preservar a estrutura urbana já existente.

As obras de saneamento da cidade não foram iniciadas neste momento por questões financeiras e políticas. No entanto, de 1913 a 1922 a cidade continuou a se expandir de acordo com a lógica da administração que se seguiu caracterizada por empreender mudanças urbanas baseadas exclusivamente em grandes projetos de embelezamento da cidade, como foi o caso da administração do médico Camilo de Holanda, cujo período de governo foi de 1916 a 1920. Neste período as obras na capital se voltavam a consolidar a tendência de ampliações, aberturas e alargamentos de ruas com destruição de casas e desapropriações. A cidade recebia uma reforma superficial apesar de carecer de serviços de esgotos e de uma ampliação da rede de abastecimento de água, ainda muito limitada a poucos pontos da cidade. A administração de Camillo de Holanda preferiu construir e reformar prédios públicos, além de reformar e embelezar praças.

O projeto de Saturnino de Brito só foi possível de ser executado entre os anos de 1922 e 1926, período que compreendeu os governos de Solon de Lucena e João Suassuna. De forma geral, o plano desenvolvido foi praticamente o mesmo concluído em 1914, salvo modificações necessárias devido aos novos arruamentos abertos nas imediações da lagoa que não coincidiram e não levaram em consideração o traçado sugerido e definido por Saturnino no projeto.

Em janeiro de 1926 são concluídas as obras de saneamento e da expansão do abastecimento de água da cidade. Com as obras houve uma melhoria do abastecimento de água encanada, no entanto, o serviço ainda se restringia à áreas mais nobres da cidade, ficando uma grande parte da população de bairros pobres a se abastecer de águas de antigos chafarizes. De acordo com Nogueira (2005), cerca de $56 \%$ das ruas da cidade, em 
1938, não eram servidas de água encanada, motivo pelo qual se conservavam ainda em uso cerca de 21 chafarizes públicos.

Quanto aos serviços de esgotos, mesmo depois de concluídos não resolveram em definitivo a questão de salubridade da população, pois a sua instalação em cada lote deveria ser custeada pelo proprietário que, na maioria das vezes não podia ou não se comprometia a pagar por esta parte do serviço. Com isso, em 1929, a população foi convocada pelo então presidente João Pessoa a financiar parte da solução com a obrigatoriedade da ligação dos esgotos domiciliares à rede geral.

No período que marca os primeiros 30 anos do século $\mathrm{XX}$ a cidade recebeu muitos dos melhoramentos urbanos que a colocavam no rol das cidades modernas. Mesmo de forma pontual e incompleta esses serviços fizeram parte da vida cotidiana de parte dos moradores da cidade da então Parahyba do Norte. A preocupação com o saneamento era

a justificativa que serviu de impulso para as modificações radicais e dispendiosas no traçado urbano da cidade. Grandes obras que necessitavam de grandes modificações, desapropriações e, principalmente, grandes verbas, e que careciam de uma justificativa mais convincente do que apenas a finalidade de embelezamento da cidade.

\section{4 - Intervenções urbanas mais recentes: a cidade e a lógica capitalista}

João Pessoa até meados da década de 1950 apresentava um ritmo de crescimento bastante lento, não havia, à época, nenhuma atividade que proporcionasse uma significativa expansão urbana além daquela já verificada pelas reformas realizadas a partir da primeira década do Século XX. Neste período, em meados dos anos de 1950, a Avenida Epitácio Pessoa foi pavimentada, facilitando a implementação de meios de transportes modernos para a época, como bondes e marinetes (CHAGAS, 2004). Ao mesmo tempo em que se construía este caminho da cidade antiga ao mar, uma outra via de expansão estava sendo criada, a Avenida Cruz das Armas, o principal acesso à cidade de Recife, área onde se formou o Bairro de Cruz das Armas. Estas reformas, com abertura de amplas avenidas, fizeram com que a cidade mudasse um pouco o seu caráter colonial, muito concentrada nas proximidades do seu centro. A abertura e pavimentação da Avenida Epitácio Pessoa fizeram com que João Pessoa se voltasse mais para a orla marítima, principalmente a partir da década de 1960. 
Com relação a modificações urbanas verificadas em João Pessoa Lavieri e Lavieri (1992), citam algumas intervenções públicas de caráter nacional que fizeram parte da política de integração nacional do Governo Federal e que foram implementadas na cidade a partir de 1963. Três importantes iniciativas marcaram este momento da evolução urbana da cidade, como a construção do anel viário, do Distrito Industrial e do Campus Universitário. Segundo os autores, o Campus Universitário foi a primeira atividade urbana a ser instalada para além do Vale do Rio Jaguaribe, já citado como um dos impedimentos naturais da expansão da cidade em momentos anteriores.

Mesmo com estes empreendimentos que favoreceram a sua expansão em meados dos anos 1960 João Pessoa permanecia com seu eixo urbano ainda concentrado na área denominada de centro. No entanto, já era possível se perceber disparidades na questão do uso do solo. A antiga diferenciação social que existia nos séculos anteriores, entre a cidade alta (que abrigava prédios administrativos e religiosos, sendo área de circulação da elite) e a cidade baixa (área da classe trabalhadora) estava agora reproduzida entre as áreas das avenidas Epitácio Pessoa e Cruz das Armas.

Apesar da importante iniciativa de construção e pavimentação da avenida Epitácio Pessoa, que dava caminho ao mar, foram necessárias ações mais efetivas para estabelecer de vez a ocupação desta parte da cidade. Este impulso só foi possível em virtude do desenvolvimento das políticas de habitação através do Sistema Financeiro de Habitação (SFH). Este novo modelo de política habitacional da época veio contribuir efetivamente na expansão urbana da cidade através de financiamentos de conjuntos habitacionais, como também de habitações isoladas (casas avulsas). Através desses financiamentos foram construídas e financiadas muitas habitações nos bairros localizados ao longo da Avenida Epitácio Pessoa. Estes financiamentos se deram através de três conjuntos habitacionais, construídos de forma a adensar algumas áreas urbanas já habitadas localizadas nos bairros de 13 de Maio, Ipês e Pedro Gondim (LAVIERI e LAVIERI, 1992).

Os autores destacam nessas ações a intencionalidade de favorecer um adensamento de habitações na área próxima à Avenida Epitácio Pessoa, favorecendo a ocupação deste perímetro entre o centro da cidade e a orla marítima. A forma seletiva desses financiamentos, destinados neste primeiro momento (1964-1968), à uma classe de 
renda média, constituída de funcionários públicos federais e estaduais, se estabelece como primeiro passo para a produção de um espaço urbano altamente segregado.

De outro lado, a construção do Conjunto Castelo Branco, em 1969, marca de forma significativa esta seletividade espacial identificada na disposição das habitações em João Pessoa. Este conjunto, de caráter mais popular, foi o primeiro empreendimento habitacional construído em área localizada após o vale do Rio Jaguaribe, nas proximidades do Campus Universitário. Este conjunto foi construído através de uma "política oficial de remoção de favelas" levada à cabo na cidade, quando da construção da Avenida Beira Rio, que terminou por desalojar muitos residentes naquela área (LAVIERI e LAVIERI, 1992, p. 16).

Esta ação de destinar às populações mais pobres as áreas mais afastadas da cidade, longe dos serviços públicos e das melhorias urbanas, já foi verificada em vários momentos históricos. Assim foi com os índios no início da formação territorial da cidade. Assim como foi também com os antigos moradores das áreas próximas à Avenida João Machado que foram "deslocados" para as proximidades do bairro de Jaguaribe quando da abertura daquela avenida (CHAGAS, 2004).

Através do estímulo dado por estas políticas de habitação ao crescimento da cidade, houve um direcionamento deste crescimento em duas direções, "uma do sul para o norte, originada pelas primeiras construções de moradia de uso permanente na região da orla marítima" (LAVIERI e LAVIERI, 1992, p. 20) e, a outra a sudeste iniciada com a construção do Campus Universitário e do Conjunto Castelo Branco. 


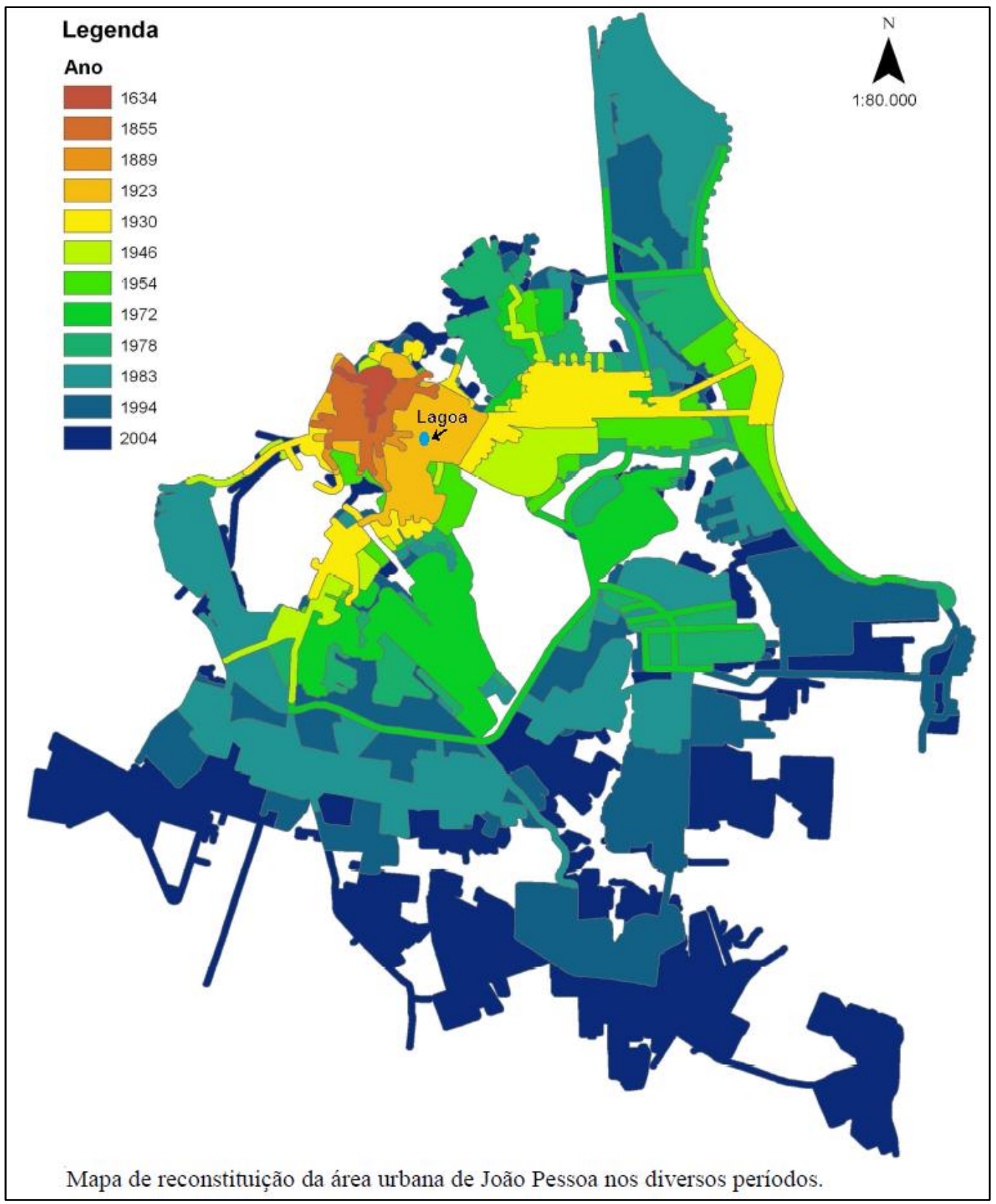

Mapa 2 - Mapa de reconstituição da área urbana de João Pessoa em diversos períodos. Fonte: Oliveira (2006)

Oliveira (2006), sintetiza através do Mapa 2, as diversas etapas de crescimento da cidade obtidas por meio de resgates de mapas desde 1634 até 2004. Percebemos no mapa as direções e as intensidades do crescimento da cidade de acordo com os anos.

Ainda Lavieri e Lavieri (1992), destacam que, pelo menos até os primeiros quatro anos da década de 1970, continuou ocorrendo uma intensa canalização de recursos de financiamentos de habitações de melhor padrão em bairros contíguos à Avenida Epitácio Pessoa, destacando o bairro dos Estados que se configurou durante as décadas seguintes 
como de alto padrão construtivo. Além disso, através do Projeto CURA ${ }^{5}$, houve a implantação de melhorias na infra-estrutura de alguns bairros selecionados, sendo a maioria deles na área da orla marítima, como Cabo Branco, Tambaú e Manaíra. Apenas o bairro do Cristo favorecido por este projeto não se localizava na orla.

Já na década de 1980 intensifica-se a questão do uso do solo na cidade favorecida pela política habitacional adotada pelos poderes públicos que empurrava a população de baixa renda para áreas cada vez mais distantes. A reestruturação urbana de João Pessoa, notadamente através de investimentos públicos e privados, acaba por reforçar a expressão a diferenciação do uso do solo. Realidade semelhante à maioria das cidades brasileiras que, por interferência do Estado através do Banco Nacional de Habitação (BNH), se vêem transformadas num modelo urbano disperso e extenso muito propenso às especulações imobiliárias. Neste contexto, a cidade se amplia com a construção dos conjuntos habitacionais populares como o Ernani Sátyro, José Américo, Ernesto Geisel e José Vieira Diniz. Todos foram construídos numa área mais afastada da orla marítima, a parte sudeste do município, e com esta ampliação aumentam também as contradições urbanas já existentes.

Verificam-se muitos investimentos em infraestrutura nas áreas consideradas nobres da cidade, notadamente nos bairros próximos à Avenida Epitácio Pessoa e nos localizados próximos à orla marítima. Nestes espaços vão se concentrando gradualmente estabelecimentos comerciais, de lazer e serviços, como bancos, hotéis, shoppings e centros comerciais, voltados para as camadas de maior poder aquisitivo. Ao mesmo tempo, a partir do final da década de 1970 ocorre na cidade um aumento significativo de aglomerados de moradias sub normais ${ }^{6}$. Tendo sido formadas inicialmente nas áreas contíguas à faixa da rodovia BR 230 no sentido à Cabedelo, como também em áreas consideradas impróprias de exploração pelo setor imobiliário como, os vales dos rios, mangues, áreas de topografia acidentada e linhas de transmissão de eletricidade.

Neste sentido, a cidade que, até finais dos anos de 1970, ainda apresentava pouca seletividade espacial, com a possibilidade de populações de diferentes níveis de renda

\footnotetext{
${ }^{5}$ Comunidade Urbana para Recuperação Acelerada.

${ }^{6}$ Denominação mais atual dada pelo IBGE no censo de 2000 para as áreas conhecidas popularmente por comunidades ou favelas
} 
coabitarem em espaços próximos e bem servidos de infra-estrutura básica, passa a apresentar uma cada vez mais crescente e expressiva segregação espacial.

Através deste rápido panorama se pode ter uma visão do contexto em que se encontra a cidade no final dos anos 1980, época em que Governo Estadual passa a inserir a Paraíba na política de megaprojetos turísticos viabilizada pelo Governo Federal. 


\section{Capítulo 2}

\section{Turismo: o novo negócio mundial?}

Após a Segunda Guerra, e mediante uma transformação radical da economia, verificou-se uma grande expansão do turismo no mundo. Isso se deu, em grande medida, como conseqüência da evolução técnica, industrial e comercial ocorrida no mundo, que gerou novas dinâmicas e transformações na economia. Neste contexto, o turismo é uma atividade relativamente nova em termos de prática social e vem crescendo, como um fenômeno mundial, num ritmo acelerado e de forma constante desde a década de 1960. Sobre sua capacidade de expansão, levando-se em conta as taxas médias de crescimento de outros setores da economia, Rabahy (2006, p. 5) destaca que o turismo "analisado sob o prisma do médio prazo, coloca-se entre os cinco principais itens geradores de divisas na economia mundial, liderados pelas exportações de armamentos e de petróleo.”

Esse avanço teve como palco inicialmente os países capitalistas desenvolvidos que viviam uma expansão econômica do pós Segunda Guerra Mundial. Apesar de apresentar crescimento constante, o turismo tem sofrido oscilações históricas em seus principais parâmetros como, o fluxo de turistas e a geração de divisas, devido às sucessivas crises econômicas, marcadamente a do final dos anos de 1960 que, segundo Harvey (1999), caracterizou a crise do modelo de produção fordista, e a crise do petróleo de 1973, que afetou a produção dos países capitalistas. Os anos de 1980 são marcados por um contexto econômico social e político influenciado por essas crises anteriores e cuja culminância se deu na direção do neoliberalismo como modelo adotado pelos estados capitalistas. Para a década de 1990, Rabahy (2006), analisando o contexto mundial do turismo sob uma ótica econômica, pondera que, apesar das crises econômicas verificadas no período de 1994 a 2004 (1994, 1997, 1999 e set. 2001), as taxas de crescimento do turismo registraram crescimento de $6 \%$ ao ano.

Diante de todas essas mudanças verificadas no mundo o turismo se coloca como uma espécie de negócio mundial, e é rapidamente cooptado pelo sistema produtivo e financeiro. As suas particularidades, marcadamente a sua alta flexibilidade como atividade produtiva - comparada aos modelos tayloristas/fordistas - fizeram com que 
servisse de esteio para uma concepção que tem estado muito presente atualmente, o chamado "fim do trabalho" (PAESE, 2002). Segundo Boletim de desempenho do turismo (BRASIL, 2014), o setor de turismo tem sido um dos poucos setores que apresentam capacidade de adaptação à dinâmica da conjuntura econômica mundial pois, mesmo diante das crises, proporciona crescimento na geração de divisas e na criação de emprego.

De maneira geral, a década de 1990 foi promissora para a atividade turística. Segundo Carvalho (2009), neste período verificou-se uma progressão no número de destinos turísticos no mundo proporcionando com isso, também, um aumento no número de receptivos e emissivos nacionais e internacionais. No gráfico 1 percebemos esse crescimento através da evolução do número de viagens internacionais realizadas no período de 1995 a 2008 que aponta um crescimento bruto de 388 milhões de viagens.

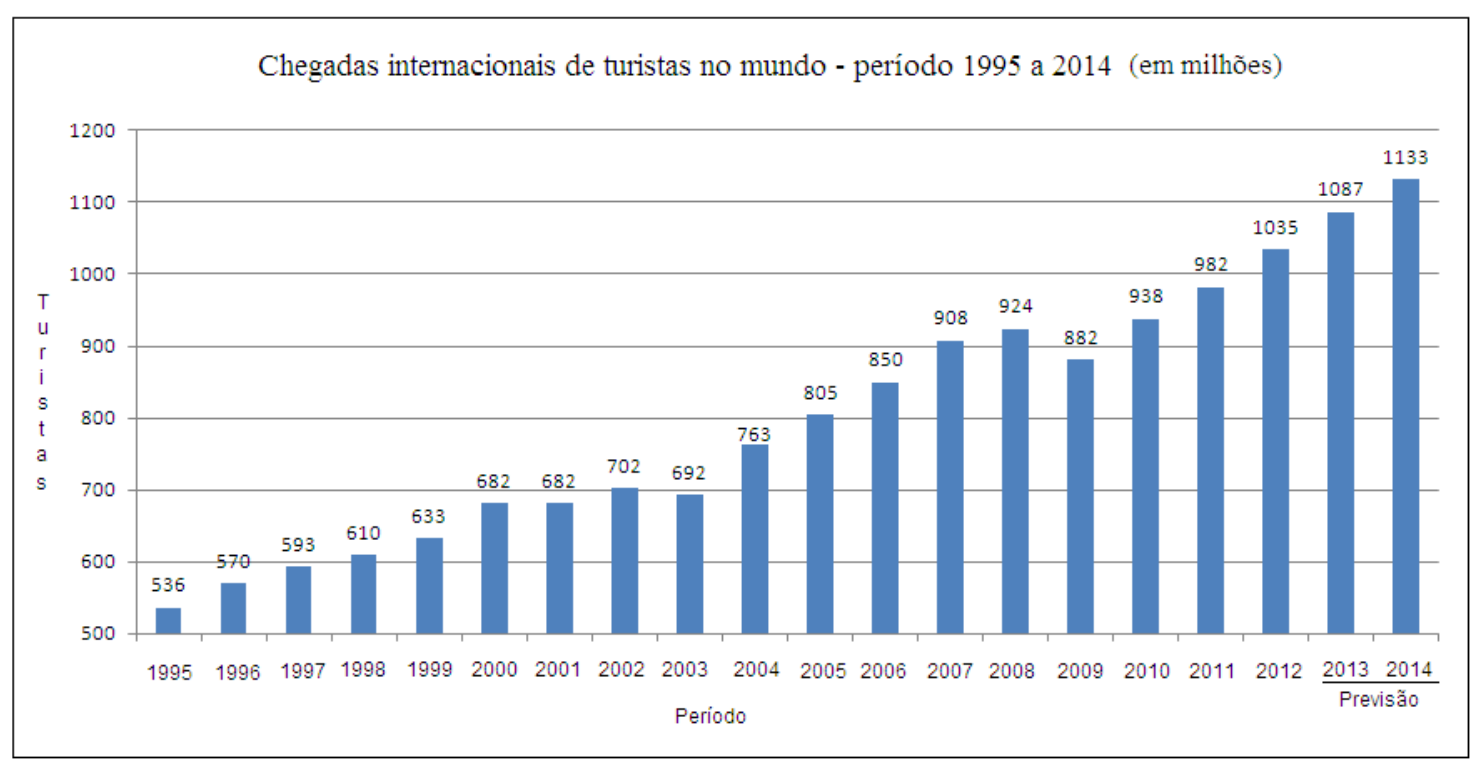

Gráfico 1 - Chegadas internacionais de turistas no mundo no período de 1995 a 2014. Fonte: Adaptado de OMT (2009), OMT (2013), BRASIL (2014).

A relevância financeira desta atividade em comparação com outros setores produtivos da economia mundial é demonstrada por Rabahy (2006), que comparou a receita gerada pelo turismo mundial com as receitas totais das exportações mundiais no período de 1990 a 2004 e verificou que, na maior parte deste período, as taxas anuais médias de crescimento das receitas de turismo equivaleram às das exportações.

Salienta o referido autor que, mesmo com oscilações econômicas causadas por acontecimentos sociais, políticos e econômicos, as chegadas de turistas internacionais evoluem a taxas de 4\% ao ano. Além disso, de acordo com Rabahy (2006), o número de chegadas é a variável que sofre menos interferências e variações anuais causadas por 
interferências econômicas, como variação de preços, inflação e cotação de dólar. Em contrapartida, a variável receitas das viagens sofre mais interferências e oscila com mais frequiência de acordo com o comportamento da economia mundial. Segundo o autor, um aumento ou manutenção das taxas anuais de fluxo turístico não necessariamente quer dizer manutenção ou aumento dos níveis das receitas provenientes das atividades ligadas ao turismo. Neste caso, pode haver "uma redução do fluxo turístico de maiores níveis de gastos em favor da expansão do turismo de menor gasto relativo" (RABAHY, 2006, p. 7).

De acordo com dados da Organização Mundial de Turismo (OMT, 2009), duas crises recentes geraram abalos na economia mundial, a crise de 2008 nos Estados Unidos, que ainda apresenta lenta recuperação, e a mais recente crise que causou indefinição da economia dos países da Zona do Euro. Mesmo assim, apesar de uma redução no número de chegadas de turistas no mundo no ano de 2009, causada provavelmente pela crise econômica dos EUA, vemos que estes números continuaram a crescer em 2010, ultrapassando um bilhão de turistas em 2012, como podemos ver no gráfico 1.

Dados do relatório Impacto Econômico de Viagens e Turismo (WTTC, 2014) apontam que, em 2013, a contribuição total do turismo para a economia alcançou 9,5\% do PIB global. O relatório demonstra que, não só houve uma contribuição maior do turismo para a economia global, mas também houve um crescimento mais rápido dos valores em relação a outros setores como, o financeiro, de serviços, de transportes e de produção.

Em vários trabalhos sobre o turismo, em especial aqueles de cunho mais econômico e quantitativo, é comum citarem duas categorias de análise, a contribuição direta e a contribuição total. Os dois termos tratam da questão da contribuição do turismo para a economia, mas apresentam significados bem diferentes, que se não estiverem bem claros, podem interferir e distorcer as conclusões acerca da realidade analisada. Sobre esta questão o World Travel \& Tourism Council (WTTC, 2012) afirma que, de maneira geral, as metodologias de cálculo dos impactos na economia consideram apenas as contribuições diretas da atividade turística. No entanto, o World Travel \& Tourism Council (WTTC), através de sua metodologia de pesquisa, propõe também a verificação da contribuição total das atividades turísticas, que é uma variável que possibilita uma amplitude maior, conseguindo capturar também os impactos indiretos e induzidos dessas 
atividades. A partir desta metodologia o WTTC apresenta duas novas variáveis, sendo a primeira a contribuição total do turismo para o PIB e a segunda, a contribuição total do turismo para a geração e manutenção do emprego. No cálculo desta contribuição total estariam incluídos gastos com investimentos, como aquisição de novas aeronaves e construção de novos hotéis; incluiria também gastos com investimentos públicos como, infraestrutura, saneamento, estradas, marketing e promoção do turismo, administração e serviços de segurança. Outros gastos indiretos também seriam considerados como, compras no mercado interno de bens e serviços por parte dos setores que lidam diretamente com os turistas, incluindo, por exemplo, as de alimentos e serviços de limpeza de hotéis, de combustível e de serviços de catering $^{7}$ por companhias aéreas e serviços de TI por agentes de viagens.

Em termos monetários a contribuição direta do turismo para o PIB mundial em 2013 foi de US\$2.155,4 bilhões (2,9 \% do PIB total), e está previsto um aumento de 4,3\% em 2014. As previsões para o período 2014-2024 também apontam um aumento de 4,2\% ao ano para US\$ 3.379,3 bilhões (3,1 \% do PIB total) em 2024. (WTTC, 2014).

Outro fator relevante para a afirmação da importância econômica do turismo é a geração e a manutenção de empregos no mundo. Em 2013 os números de empregos mantidos pelo turismo no mundo somam aproximados 266 milhões, ou seja, a cada onze empregos no mundo, um está ligado ao setor de turismo (WTTC, 2014). As previsões a longo prazo apontam um crescimento favorável para taxas superiores a $4 \%$ ao ano, que continuam a ser maiores que as taxas previstas para outros setores. Em 2013 o turismo contribuiu diretamente com 100.894.000 de empregos no mundo (3,4\% do emprego total). Previsões apontam para o período de 2014-2024 um aumento de 2,0\% ao ano para o número de empregos diretos, passando a ser responsável por 3,7 \% do total de empregos no mundo (WTTC, 2014).

\section{1 - O turismo no Brasil: entre a realidade e a ilusão dos discursos por trás dos dados}

\footnotetext{
${ }^{7}$ Serviço de fornecimento de alimentação em grande escala em lugares remotos
} 
A América do Sul, segundo a OMT, tem sido uma das regiões que vem apresentando melhor desempenho no quadro de previsões de chegadas de turistas internacionais, cujas projeções apontam uma movimentação de 1,6 bilhões de turistas pelo mundo em 2020 (PNT, 2013). O Brasil é apontado como principal destino turístico da região e responsável pelo crescimento e consolidação deste desempenho da América do Sul no contexto das previsões no âmbito mundial (Aquarela, 2020).

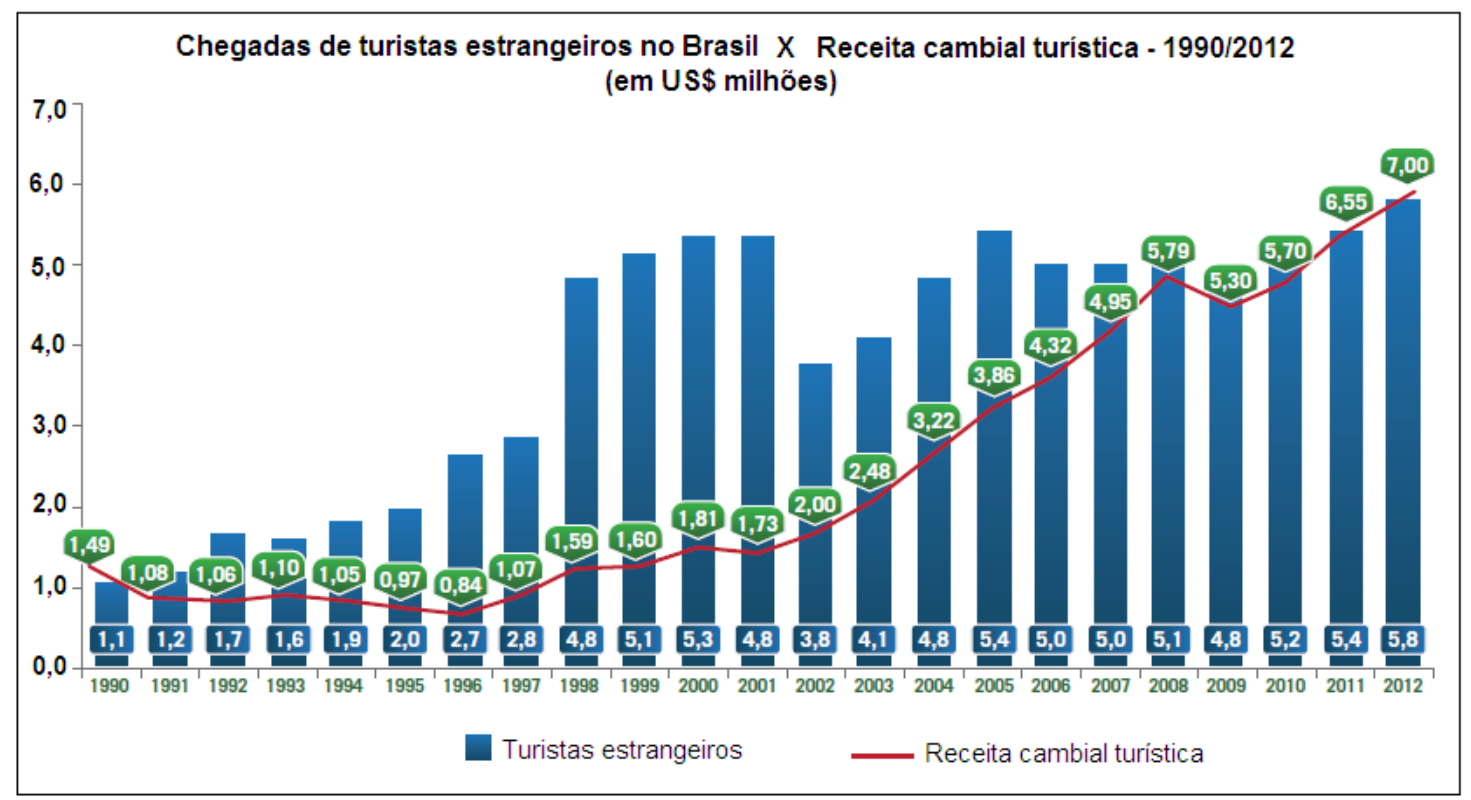

Gráfico 2 - Chegadas de turistas estrangeiros no Brasil X receita cambial turística. Fonte: (PNT, 2013).

Os dados dispostos no gráfico 2 (chegadas de turistas versus receita cambial) registram uma evolução positiva na chegada de turistas estrangeiros no Brasil até o ano de 2001. Para esta mesma variável observamos no período de 1990 a 1997 um número médio em torno de 1,8 milhões de turistas. Este valor se eleva abruptamente a partir de 1998, e se mantém no período de 1998 a 2001 com uma média de 5 milhões de turistas chegando no país.

A série de dados registra em 2002 uma queda nos valores provavelmente por causa da crise ocasionada pelos atentados de 11 de setembro 2001 nos Estados Unidos que afetou mundialmente o fluxo de turistas internacionais. É necessário observar que nestes dois períodos citados, que abrange os anos de 1990 a 2001, mesmo com um aumento progressivo em valores aproximados de 1 milhão para 5 milhões de turistas, não houve um aumento na mesma proporção das receitas que oscilaram em torno de 840 mil a 1,8 milhões de dólares. Confirmando em parte o que Rabahy (2006) argumenta que, o aumento do número de turistas não garante o aumento de receitas. 
A atividade turística tem sido responsável por uma importante parcela da renda gerada no Brasil. Segundo o World Travel \& Tourism Council (WTTC, 2011), em 2011 o setor de turismo foi responsável pelo faturamento, no país, de mais de 78 bilhões de dólares, posicionando o Brasil em $6^{\circ}$ lugar em geração de renda proveniente do turismo. Na tabela 1 estão dispostos os onze países que mais geram renda de atividades turísticas, com os Estados Unidos e a China, em primeiro e segundo lugares do ranking, respectivamente, e o Brasil na liderança entre os países da América Latina.

Tabela 1

Ranking dos 11 países que mais geram renda proveniente da atividade turística (2011)

\begin{tabular}{llr}
\hline Ranking & País & US\$ (Bilhões) \\
\hline $1^{\mathbf{o}}$ & Estados Unidos & 434.353 \\
$2^{\text {o }}$ & China & 181.619 \\
$3^{\text {o }}$ & Japão & 123.534 \\
$4^{\text {o }}$ & França & 102.769 \\
$5^{\mathbf{o}}$ & Espanha & 80.193 \\
$\mathbf{6}^{\mathbf{o}}$ & Brasil & $\mathbf{7 8 . 5 0 3}$ \\
$7^{\mathbf{o}}$ & Itália & 71.551 \\
$8^{\text {o }}$ & México & 63.734 \\
$9^{\mathbf{o}}$ & Alemanha & 58.276 \\
$1^{\circ}$ & Reino Unido & 56.155 \\
$11^{\mathbf{o}}$ & Índia & 36.192 \\
\hline
\end{tabular}

Fonte: WTTC (2011)

Sabe-se que a renda gerada pelo turismo está diretamente ligada aos gastos realizados pelos turistas. Parte dessa renda é gerada através de atividades como, hospedagem, alimentação, transportes e lazer, dentre outras. As empresas responsáveis por esses serviços são, dentro do setor, as mais numerosas, sendo as que mais dinamizam a atividade, movimentando divisas, gerando empregos, se constituíndo como a base dos serviços essenciais necessários aos turistas.

A geração de emprego e renda ligados às atividades de turismo também passa a ser uma contribuição importante deste setor para a economia do país. Além de possibilitar a fixação das pessoas em empregos nos seus lugares de origem, proporciona uma grande variedade de postos de trabalho com diversos níveis de formação, além de gerar demanda 
para prestação de serviços fomentando os pequenos investidores e trabalhadores freelance (PNT, 2013). Este é o discurso que está fortemente marcado nos documentos oficiais do governo que tratam da questão do turismo como atividade propulsora da economia do país. Através deste discurso se ocultam relações econômicas desiguais e onde se lê "postos de trabalho com diversos níveis de formação", leia-se, "muitos empregos sem exigência de qualificação profissional e que pagam baixos salários". E onde se lê "pequenos investidores e trabalhadores freelancer", leia-se, "muitos postos de trabalho informal".

Mesmo assim, não há como negar que, no Brasil, a contribuição direta do turismo para o PIB em 2011 foi de R \$ 131,5 bilhões (3,2\% do PIB) (WTTC, 2011). Este valor é reflexo direto de atividades econômicas geradas por hotéis, agências de viagens, companhias aéreas e outros serviços de transporte de passageiros. Incluindo também atividades de restaurantes e lazer, como também indústrias ligadas diretamente às necessidades e demandas do setor turístico.

\section{2 - Turismo brasileiro: o desequilíbrio na balança cambial e seu déficit histórico}

Os números da economia do turismo apontam para o Brasil um cenário positivo em relação ao PIB, à chegada de turistas estrangeiros, à geração de empregos, sendo essas as variáveis mais relevantes dentre inúmeras outras ligadas ao setor. No entanto, é fato que existe um problema muito preocupante na balança cambial do turismo e que merece atenção.

Apesar da relevância da questão do impacto do desequilíbrio do câmbio do turismo não há muitos trabalhos na linha do turismo discutindo estas questões. Compreender este impacto sobre o balanço de pagamentos e a entrada de divisas advindas do turismo é uma questão fundamental. Pois é preciso entender a importância da atividade para a economia levando em conta o que Rabahy (2006) alerta, sobre a necessidade de se observar não somente o fluxo de entradas e saídas de turistas no país, mas também a questão do montante de divisas deixadas por eles, tanto aqui no país pelos estrangeiros, como lá fora pelos brasileiros.

O impacto de um desequilíbrio entre receitas e despesas gera um problema na economia do turismo semelhante ao problema econômico do balanço de importações e 
exportações do país. Ou seja, quando há maior quantidade de importações e menor quantidade de produtos exportados, isso gera falta de divisas para saldar as dívidas e compromissos financeiros internacionais. Da mesma forma acontece na economia gerada pelo turismo, quando se verificam muitos turistas brasileiros saindo do país e gastando muito mais divisas estrangeiras, do que os turistas estrangeiros gastam quando chegam ao Brasil.

Desta forma, podemos perceber, através dos dados da tabela 2, o déficit histórico existente nas receitas e despesas das atividades turísticas do país, que acumulam no período de 1990 a 2012 o valor negativo de 135.207 bilhões de dólares. Apenas os anos de 2003 e 2004 apresentam valores positivos no balanço entre a receita e a despesa. Estes crescentes saldos negativos têm acontecido em função da crescente ascensão da renda interna e da valorização cambial da moeda nacional. O ano de 2012 apresentou um déficit de US\$ - 15.588 bilhões de dólares, aumento causado provavelmente pela desvalorização do Real em comparação ao Dólar americano (PNT, 2013) e pela desindustrialização verificada no país.

Uma melhora nesse balanço cambial turístico pode ser notada nos resultados da receita turística para o ano de 2012 que somaram US\$ 6.645 bi, sendo este o maior resultado histórico segundo dados da Tabela 2, apesar da pouca variação no número de turistas que chegaram ao país, sendo 5,2 milhões em 2010, 5,4 milhões em 2011 e 5,8 milhões em 2012.

Mesmo apresentando esse déficit histórico entre receitas e despesas, a atividade de turismo no Brasil tem sido cogitada como caminho para o desenvolvimento econômico. Nesse contexto, o Plano Nacional do Turismo (Brasil, 2013) afirma que o país tem se preparado, através de diversas políticas públicas, para ser capaz de competir no mercado do turismo e se tornar, em oito anos, no terceiro Produto Interno Bruto turístico do mundo, atrás apenas da China e dos Estados Unidos.

\section{Tabela 2}

Totais de receita e despesa cambial turística e superávit ou déficit do Brasil Período de 1990 a 2012 (Milhões US\$). 


\begin{tabular}{rrrr}
\hline Ano & Receita & Despesa & Déficit/Superávit \\
\hline 1990 & 1.489 & 1.579 & -90 \\
1991 & 1.076 & 1.315 & -239 \\
1992 & 1.064 & 1.402 & -338 \\
1993 & 1.096 & 1.890 & -794 \\
1994 & 1.048 & 2.230 & -1.182 \\
1995 & 972 & 3.391 & -2.419 \\
1996 & 840 & 4.438 & -3.598 \\
1997 & 1.069 & 5.446 & -4.377 \\
1998 & 1.586 & 5.732 & -4.146 \\
1999 & 1.628 & 3.085 & -1.457 \\
2000 & 1.810 & 3.894 & -2.084 \\
2001 & 1.731 & 3.199 & -1.468 \\
2002 & 1.998 & 2.396 & -398 \\
2003 & 2.479 & 2.261 & 218 \\
2004 & 3.222 & 2.871 & 351 \\
2005 & 3.861 & 4.720 & -859 \\
2006 & 4.316 & 5.764 & -1.448 \\
2007 & 4.953 & 8.211 & -3.258 \\
2008 & 5.785 & 10.962 & -5.177 \\
2009 & 5.305 & 10.898 & -5.593 \\
2010 & 5.702 & 16.420 & -10.718 \\
2011 & 6.555 & 21.264 & -14.709 \\
2012 & 6.645 & 22.233 & -15.588 \\
\hline Total & $\mathbf{3 5 . 7 3 6}$ & $\mathbf{1 7 0 . 9 4 3}$ & $\mathbf{- 1 3 5 . 2 0 7}$ \\
\hline
\end{tabular}

Fonte: BRASIL (2014)

Assim, de acordo com os direcionamentos do Plano Nacional do Turismo, a atividade tem sido vista pelo governo como uma via importante na expansão da economia local, na geração de divisas, empregos e renda e na movimentação de diversos segmentos de produtos e serviços. É considerada, inclusive, como uma atividade capaz de impulsionar o desenvolvimento econômico em diversas regiões do país possibilitando a diminuição das desigualdades entre regiões. Algumas projeções acerca do panorama do país dentro do contexto do turismo mundial têm sido apresentadas com números bastante positivos para o futuro (WTTC, 2011, 2012, 2014). Assim, percebemos que o discurso governamental, nos últimos anos, tem sido marcado por um otimismo acerca do poder do turismo para resolver questões complexas e historicamente constituídas (SANSOLO e CRUZ, 2003). 
No entanto, é preciso ponderar sobre a utilização de parâmetros numéricos para as análises das conjunturas do turismo em qualquer nível que seja, mundial, regional ou local. A mensuração dos aspectos da realidade é necessária, o problema é tomar como verdade absoluta essas dimensões sem buscar compreender as contradições existentes entre a realidade e os dados. É fato que muitos discursos presentes nos relatórios de pesquisas realizadas sobre o tema podem conter uma visão muito positiva ou um otimismo exacerbado sobre as possibilidades de retorno (econômico e social) das atividades turísticas. Muito além da capacidade que esta atividade teria para resolver questões e problemas cruciais gerados historicamente nos territórios turísticos.

Nesse sentido, Cazes (2001), mesmo fazendo uma crítica contundente acerca das estatísticas notadamente positivas, reconhece que é importante que se tome consciência da realidade da "amplitude econômica do turismo no mundo" (CAZES, 2001, p. 79) e, para isso, não há como deixar de lançar mão dos dados estatísticos. O cuidado, porém, deve estar nas análises, principalmente nas referentes às vantagens econômicas e ao retorno de divisas. $\mathrm{O}$ autor chama atenção para o aspecto ilusório das entradas de receitas referentes ao turismo.

Outra via que merece cuidado ao ser considerada são as estatísticas referentes ao número de empregos. No Brasil, em 2003, o IBGE contabilizou mais de 2 milhões de pessoas ocupadas em empresas pertencentes às Atividades Características do Turismo (IBGE, 2003). Neste levantamento foi registado um número expressivo de empresas do setor de alimentação $(81,49 \%)$ e, consequentemente, um grande número de pessoal ocupado neste setor $(65,37 \%)$. Merece destaque o fato de que, apesar do grande número de empresas do setor de alimentação e da significativa quantidade de pessoal ocupado, este setor apresentou os menores valores de remuneração média mensal do trabalhador para o grupo ${ }^{8}$. Esse baixo nível de salário é decorrente, dentre outros fatores, do baixo grau de qualificação que o pessoal ocupado apresenta.

\footnotetext{
${ }^{8}$ Este grupo é formado pelas empresas caracterizadas na pesquisa como Atividades Características do Turismo. Essas atividades são as seguintes: serviços de alimentação, transporte rodoviário, serviços desportivos e de lazer, aluguel de automóveis, transporte aquaviário, serviço de alojamento, agências de viagens, auxiliares dos transportes e transportes aéreos (IBGE, 2003).
} 
Levando em consideração todas as categorias de emprego relacionadas no grupo de Atividades Características do Turismo, o rendimento médio mensal das pessoas ocupadas neste setor, no ano de 2003, correspondeu a R\$577,00 ou seja, aproximadamente 2,5 salários mínimos ${ }^{9}$ (IBGE, 2003).

Considerando o número total de pessoas ocupadas em atividades do turismo ${ }^{10}$ no ano de 2003, estimado em 5.495.800 pessoas, o IBGE aponta um predomínio do gênero masculino com $63,63 \%$, em relação ao feminino com $36,37 \%$. Outro fator relevante a ser mencionado diz respeito à grande quantidade de pessoal ocupado sem carteira de trabalho assinada que ficou próximo aos 40\%, o que evidencia um grande número de trabalhadores ligados ao turismo trabalhando na informalidade (IBGE, 2003).

Deste modo, mesmo as estatísticas apresentando números positivos, é preciso que as análises sejam feitas levando em conta as especificidades de cada realidade, pois nem sempre um valor positivo garante uma situação vantajosa, principalmente no que diz respeito aos trabalhadores. No gráfico 3 vemos que existe uma grande quantidade de empresas de pequeno porte (dentre elas as do setor de alimentação) que empregam mais de $60 \%$ dos trabalhadores ligados ao turismo no Brasil. No entanto, essas empresas são as que geram menos receitas e as que pagam os menores salários aos trabalhadores. É visível a disparidade na distribuição de renda proveniente das atividades do turismo, que pode ser percebida. Poucas empresas geram as maiores receitas e pagam os maiores salários, em contrapartida elas empregam menos trabalhadores.

Segundo os dados do IBGE, podemos inferir que a maior parte do capital que gira no setor do turismo está concentrado em poucas empresas que, proporcionalmente, repassam os maiores salários a um número menor de trabalhadores. $\mathrm{O}$ turismo, portanto, (apesar de toda propaganda de suas vantagens econômicas) é uma atividade gerada pelo capitalismo, que se apropria em grande medida da mais-valia dos trabalhadores. Todos os trabalhadores inseridos no contexto do turismo contribuem com a sua mais-valia para que este setor econômico acumule capital. O trabalhador ligado diretamente ao setor contribui por meio de seu capital-trabalho, assim como o turista que contribui, cedendo o

\footnotetext{
${ }^{9}$ O valor do salário mínimo em 2003 era $\mathrm{R} \$ 240,00$.

${ }^{10}$ Referem-se ao trabalho exercido em qualquer tipo de estabelecimento tenha este registro formal ou não.
} 
que lhe restou de sua mais-valia, por meio do capital-dinheiro. Na realidade, o capital tem se apropriado até mesmo do tempo livre dos trabalhadores.

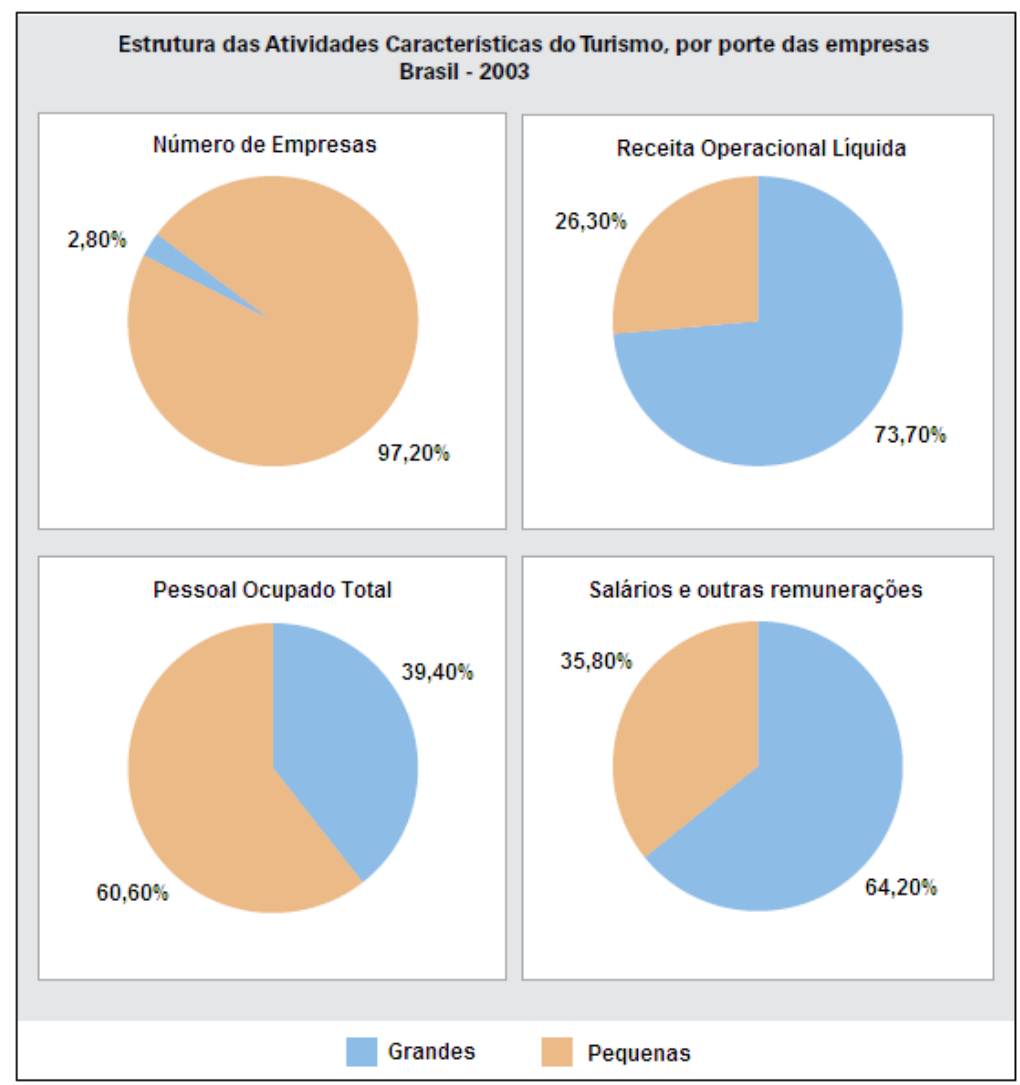

Gráfico 3 - Estrutura das Atividades Características do turismo, por porte das empresas, no Brasil no ano de 2003.

Fonte: IBGE, 2003.

Existe certo consenso geral quando se trata da relevância do papel que este setor pode exercer na geração de divisas e de empregos e com esta visão o turismo passa a ocupar um lugar de destaque no planejamento das políticas públicas de muitos países. Este fato tem se evidenciado, a partir do avanço do neoliberalismo que, segundo Cruz (2006, p. 347), mudou "o paradigma do desenvolvimento econômico até então vigente", colocando a geração de emprego e renda como "o grande desafio do final do século XX e início do século XXI”. No entanto, é necessário que se perceba algumas contradições quase imperceptíveis aos olhos menos atentos no que se refere ao papel do turismo como a tábua de salvação, ou "o último recurso ante as desilusões encontradas pelos outros setores econômicos" (CAZES, 2001, p. 80). Muito pertinente neste caso é a indagação de Cruz (2006) sobre as possibilidades reais de o turismo conseguir reverter desigualdades e injustiças sociais, sendo ele uma atividade cuja essência nasce num capitalismo altamente acumulador de riquezas e fomentador de injustiças sociais. Ainda Cruz (2005), 
sobre o discurso da possibilidade do turismo diminuir desigualdades regionais, argumenta:

\begin{abstract}
Soma-se à clara e inaceitável negligência com o território, o insustentável discurso da diminuição das desigualdades regionais, como se o turismo, uma atividade setorial, fosse capaz de reverter, por si, uma realidade histórica e estruturalmente concebida, expropriadora, excludente e espacialmente seletiva, típica do modo de produção a que estamos submetidos (CRUZ, 2005, p. 35).
\end{abstract}

Cruz (2006) destaca que esta compreensão do turismo como viabilizador de distribuição de riqueza também encontra esteio na compreensão desta atividade como viável em todos os lugares do planeta, ao contrário da indústria que se caracteriza por ser muito mais seletiva e concentrada espacialmente. No entanto, a autora chama a atenção para a diferença que existe entre distribuição espacial e distribuição estrutural da riqueza.

Além disso, outro elemento capaz de trazer à tona outras reflexões é a diferença estrutural entre as características das atividades da indústria e do turismo. A primeira apresenta, em sua estrutura produtiva, muito mais insumos de capital do que a segunda, cuja organização produtiva se baseia mais no insumo trabalho (COELHO, 2011).

Deste modo, é fato que, ao longo dos últimos anos, o turismo vem contribuindo fortemente com a economia mundial, se consolidando como uma atividade que participa de forma direta e efetiva na geração e na ampliação do PIB de inúmeras nações. Definitivamente o turismo reclama para si o seu papel de protagonista no campo comercial internacional, sendo percebido e considerado pelos administradores que se curvam ante as exigências de um mercado relativamente novo que exige adequações quase inegociáveis para levar às cidades seus "efeitos positivos". No entanto, é importante destacar que a participação do turismo vai além de meras estatísticas, em sua maioria positivas, na economia. É preciso que se tomem as precauções quanto à visão do turismo como tábua de salvação e meio de resolver todas as carências da economia dos lugares. O turismo, assim como outras atividades da economia, é passível de um planejamento que considere não apenas a dimensão econômica, mas principalmente a social. 


\section{3 - João Pessoa: ponto de referência para o turismo da Paraíba}

Apesar da importância que vem apresentando o setor de turismo na economia do país, de acordo com a FIPE (BRASIL, 2012), tem sido um desafio dimensionar o turismo doméstico no Brasil. A grande dimensão do território e as diversidades de contextos regionais tem tornado complicada a tarefa de mensuração de suas atividades. Várias instituições têm realizado estudos e pesquisas referentes ao turismo no âmbito brasileiro, como a FIPE (Fundação Instituto de Pesquisas Econômicas), a FGV (Fundação Getúlio Vargas) e o IBGE (Instituto Brasileiro de Geografia e Estatística) que muito tem ajudado na compreensão da realidade brasileira.

Se a realidade turística brasileira ainda carece de dados para a efetivação de análises bem estruturadas sobre o tema, o que dizer das realidades locais? No que diz respeito à Paraíba que é citada nos estudos e pesquisas a nível nacional, os dados relativos ao turismo do Estado muitas vezes aparecem de uma forma secundária, apenas citados através de porcentagens, em meio à análises cujos enfoques são direcionados para os principais centros turísticos de maior expressividade. No entanto, alguns órgãos locais ${ }^{11}$ ligados ao setor têm trabalhado no sentido de suprir essa carência de dados da realidade turística da Paraíba, cada um enfocando a temática sob um prisma específico de acordo com a natureza de seus objetivos.

No esforço de compreender a situação do turismo da Paraíba e de João Pessoa muitas vezes é necessário buscar referência nos dados relativos ao Brasil. Para tanto, apresentaremos um panorama geral das variáveis mais consideradas nos estudos ligados à temática, buscando sempre dar enfoque para a cidade de João Pessoa, até onde a natureza dos dados nos permitir.

O turismo movimenta a economia como um todo e não há como afirmar o contrário. No Nordeste, segundo dados do IPEA, o total de empregados formais ocupados em atividades características do turismo no ano de 2008 somou 165.181 milhões. Em destaque, na tabela 3, estão os Estado da Bahia e de Pernambuco, responsáveis juntos por mais da metade dos empregos formais. Se agruparmos os percentuais dos Estados da

\footnotetext{
${ }^{11}$ IFEP (Instituto Fecomércio de Pesquisas Econômicas e Sociais da Paraíba); PBTUR (Empresa Paraibana de Turismo).
} 
Bahia, Pernambuco, Ceará e Rio Grande do Norte esse valor chega a 73\%, o restante, ficaria distribuído entre os outros Estados do Nordeste. Na Paraíba este total foi equivalente a 8.738 , que representou 5,28\% do total do Nordeste (COELHO, 2011).

\section{Tabela 3}

\begin{tabular}{cc} 
Participação relativa das UFs no emprego formal das ACTs na Região \\
Nordeste - Dezembro de 2008 (em \%) \\
\hline UF & Formal \\
\hline BA & 30,6 \\
PE & 20,7 \\
CE & 12,1 \\
RN & 8,8 \\
MA & 7,0 \\
AL & 6,2 \\
PB & 5,3 \\
SE & 5,1 \\
PI & 4,2 \\
\hline Total & $\mathbf{1 0 0} \%$
\end{tabular}

Fonte: Coelho (2011)

O fluxo global de turistas na Paraíba, segundo dados da PBTUR, tem apresentado crescimento constante no período de 2003 a 2013, representando uma taxa de $8 \%$ de crescimento ao ano. O gráfico 4 apresenta a perspectiva deste crescimento para o período, onde percebemos que, apesar de uma queda de 16,5\% no fluxo de turistas do ano de 2002 para 2003, houve no ano seguinte uma recuperação de cerca de $25 \%$ neste fluxo.

O principal motivo de visita a João Pessoa de acordo com o IFEP foi turismo e lazer, com 56,48\%, seguido de visitas a parentes e amigos, com 36,05\%. Dos turistas em primeira visita à João Pessoa, 77,56\% estavam viajando a lazer, permanecendo um tempo médio de dez dias na cidade, sendo que, cerca de metade, permaneceram de três a oito dias (IFEP, 2014). 


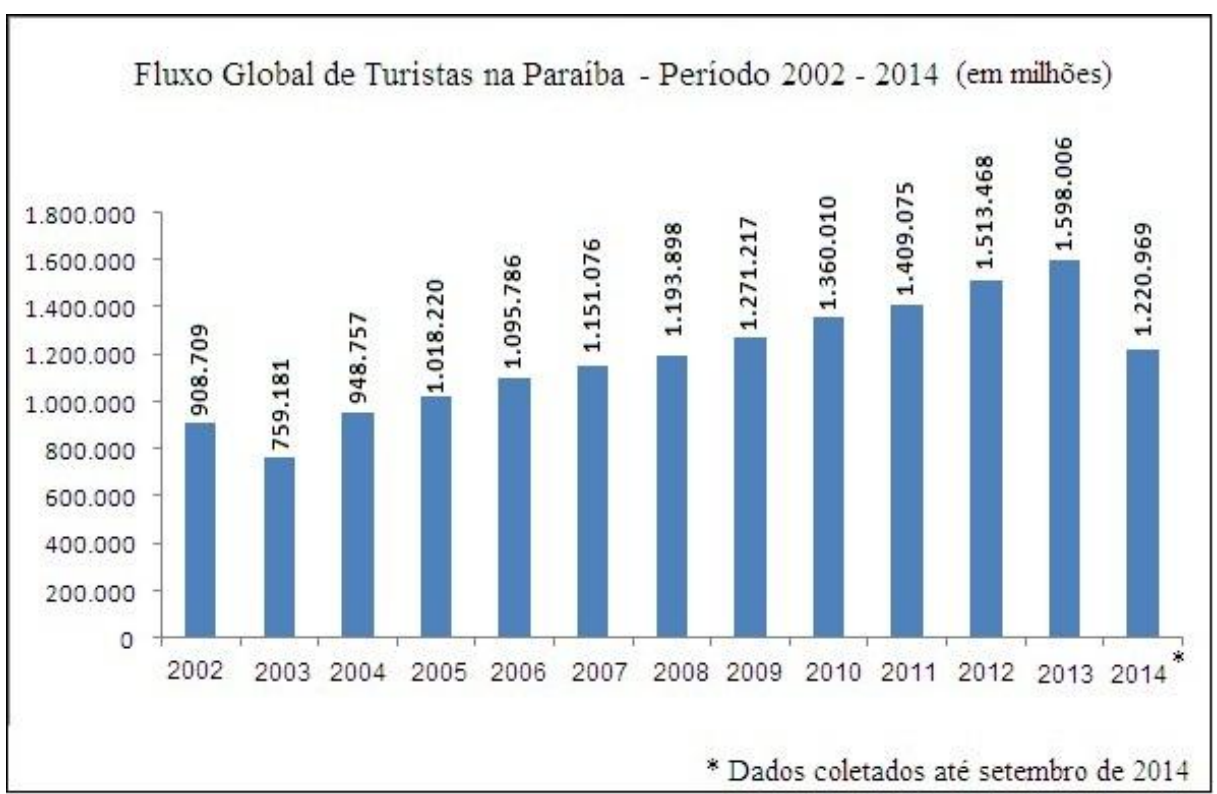

Gráfico 4 - Fluxo global de turistas na Paraíba no período de 2002 a 2014. Fonte: PBTUR

João Pessoa apresenta um panorama do fluxo de turistas bem semelhante ao do Estado para o mesmo período considerado, com uma média de crescimento de $6 \%$ ao ano. No gráfico 5 fica evidente que este percentual é muito significativo, tendo João Pessoa apresentado, por ano, uma média de $70 \%$ do total do fluxo de turistas do Estado. Considerando o intervalo de tempo entre 2003 e 2013, verificamos um aumento superior a $100 \%$ no fluxo de turistas na cidade.

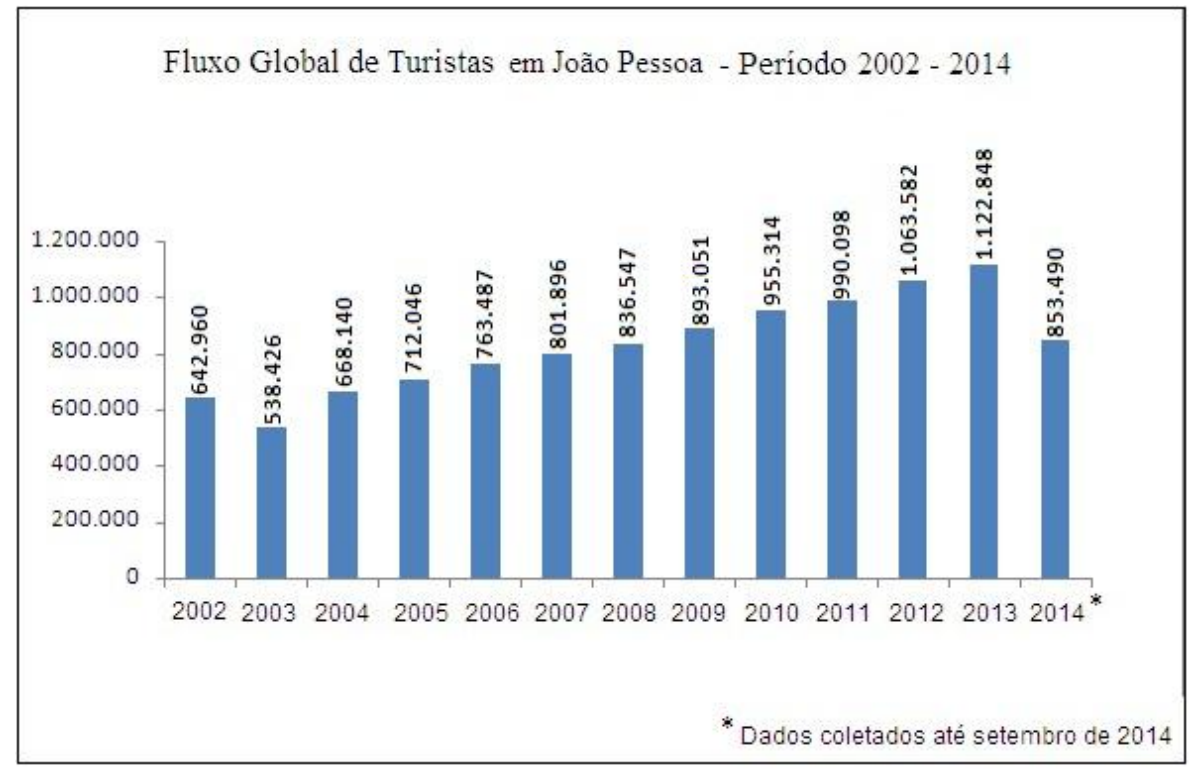

Gráfico 5 - Fluxo global de turistas em João Pessoa no período de 2002 a 2014. Fonte: PBTUR 
Esse percentual alto (70\%) do fluxo de turistas na cidade de João Pessoa em relação ao número total de turistas por ano para todo o Estado pode estar relacionado, em grande parte, à promoção intensiva do litoral que tem sido realizada para todo o Nordeste, principalmente desde o final da década de 1980. Esta iniciativa tomou impulso a partir de algumas políticas de desenvolvimento do turismo, como o PRODETUR-NE que, na Paraíba, centrou as suas prioridades no eixo do litoral, favorecendo, assim, oportunamente a capital por sua localização junto ao mar.

Dados apontam que, em 2014, dentre as três principais razões que levaram os turistas escolher João Pessoa como o destino de sua viagem, estão as belezas das praias, a visita a parentes e amigos e os atrativos naturais (IFEP, 2014). Na tabela 4 podemos visualizar as principais razões porque os turistas escolheram a Região Metropolitana de João Pessoa como destino turístico.

\section{Tabela 4}

Pesquisa Anual do Desempenho do Turismo na Região Metropolitana de João Pessoa Distribuição da amostra segundo a razão da RMJP como destino turístico Ano 2014

\begin{tabular}{l|c}
\hline RAZÃO DA ESCOLHA DA RMJP COMO DESTINO TURÍSTICO & PERCENTUAL \\
\hline As praias & 69,77 \\
\hline Visitar parentes ou amigos & 45,02 \\
\hline Atrativos naturais & 32,23 \\
\hline Indicação de parentes ou amigos & 23,59 \\
\hline Propaganda na internet & 13,62 \\
\hline O verde da cidade & 13,46 \\
\hline Pela proximidade do local de origem & 8,31 \\
\hline Propaganda em revistas/televisão & 7,97 \\
\hline Trabalho & 4,49 \\
\hline Preço da viagem mais adequado & 4,15 \\
\hline Indicação de agências de viagem & 3,82 \\
\hline Tranquilidade da cidade & 2,99 \\
\hline Gosta da cidade & 1,99 \\
\hline Programação cultural & 1,66 \\
\hline Eventos & 1,33 \\
\hline Conhecer o Nordeste & 0,83 \\
\hline Fest Verão Paraíba & 0,83 \\
\hline Residência própria & 0,83 \\
\hline Estudo & 0,66 \\
\hline Conhecer a Paraíba & 0,66 \\
\hline Tratamento de saúde & 0,50 \\
\hline Facilidade de locomoção & 0,50 \\
\hline Outros & 0,17 \\
\hline
\end{tabular}

Fonte: IFEP (2014) 
Claro que o fato de João Pessoa dispor das vantagens da infra estrutura de estradas e de contar com o principal aeroporto do Estado favorece o aumento desse fluxo de turistas. No entanto, na tabela 4 podemos perceber o item "conhecer a Paraíba", que apresentou o terceiro menor percentual de todos $(0,66 \%)$, confirmando que o turista prefere as praias e o litoral. Nesta pesquisa foi identificado que $63,03 \%$ de turistas já havia visitado a cidade pelo menos uma vez anteriormente. Isso indica uma grande porcentagem de turistas com intenção de voltar à cidade em outras viagens de turismo.

O grau de satisfação dos turistas foi alvo de investigação por parte da Pesquisa Anual do Desempenho Turístico da Região Metropolitana de João Pessoa (IFEP, 2014). Na pesquisa foi solicitado aos visitantes que classificassem os serviços por eles utilizados na ocasião da sua permanência de acordo com os seguintes níveis de satisfação: Ótimo/Bom, Regular e Ruim/Péssimo.

De acordo com os resultados, dispostos na tabela 5, os itens que apresentaram os maiores níveis de satisfação foram, a Receptividade do Paraibano com 96,32\%, seguida da Gastronomia com 95,21\%, as Instalações de Hospedagem com 90,04\%, o Guia de Turismo que obteve 88,57\%, o Atendimento no Aeroporto Castro Pinto com 88,52\%, a Diversão Noturna com $87,76 \%$ e o Comércio com 87,26\% (IFEP, 2014).

\section{Tabela 5}

Pesquisa Anual do Desempenho do Turismo na Região Metropolitana de João Pessoa 2014 Distribuição da amostra segundo classificação dos serviços turísticos na RMJP (\%)

\begin{tabular}{l|c|c|c|c}
\hline SERVIÇOS & Ótimo/Bom & Regular & Ruim/Péssimo & Ns/Nr \\
\hline Receptividade do paraibano & 96,32 & 3,01 & 0,50 & 0,17 \\
\hline Gastronomia & 95,21 & 4,11 & 0,34 & 0,34 \\
\hline Qualidade das instalações da Hospedagem & 90,04 & 8,66 & 1,30 & 0,00 \\
\hline Guia de Turismo & 88,57 & 4,29 & 4,29 & 2,85 \\
\hline Atendimento no aeroporto & 88,52 & 9,12 & 1,35 & 1,01 \\
\hline Diversão Noturna & 87,76 & 8,45 & 3,79 & 0,00 \\
\hline Comércio & 87,26 & 10,84 & 1,52 & 0,38 \\
\hline Satisfação custo x benefício da Hospedagem & 83,12 & 13,85 & 3,03 & 0,00 \\
\hline Qualidade atendimento dos Rest./Bares/Lanchonetes & 82,71 & 13,91 & 2,82 & 0,56 \\
\hline Sinalização Turística nas estradas da PB & 81,26 & 8,88 & 7,89 & 1,97 \\
\hline Sinalização Turística na RMJP & 79,33 & 12,02 & 7,21 & 1,44 \\
\hline Satisfação custoxbenefício dos Rest./Bares/Lanchonetes & 78,68 & 18,11 & 2,64 & 0,57 \\
\hline Informações Turísticas & 73,44 & 10,94 & 10,94 & 4,68 \\
\hline Atendimento na rodoviária & 61,17 & 26,06 & 9,58 & 3,19 \\
\hline
\end{tabular}

Fonte: IFEP (2014)

Os menores níveis de satisfação foram verificados para, a Informação Turística com 10,94\%, a Rodoviária com 9,58\%, a Sinalização Turística nas Estradas da Paraíba com 7,89\% e a Sinalização Turística na Região Metropolitana com 7,21\%. 
Durante a coleta dos dados dessa pesquisa foi solicitado também aos turistas que eles citassem livremente alguns "pontos positivos" ou "aspectos" de que mais gostaram na viagem. Nos dados da tabela 6 podemos ver que as praias foram citadas como o principal aspecto positivo e que o turista mais gostou ao ter visitado a Paraíba. O percentual para esse item ficou em $56,93 \%$ do total das respostas. A receptividade do povo paraibano também foi citada $(18,07 \%)$, juntamente com a gastronomia $(8,61 \%)$, a tranqüilidade $(6,25 \%)$ e as belezas naturais $(5,41 \%)$ (IFEP, 2014).

\section{Tabela 6}

Pesquisa Anual do Desempenho do Turismo na Região Metropolitana de João Pessoa 2014 Distribuição da amostra segundo os pontos positivos encontrados na Paraíba

\begin{tabular}{l|c}
\hline PONTOS POSITIVOS NA RMJP & PERCENTUL \\
\hline Praias & 56,93 \\
\hline Receptividade do povo paraibano & 18,07 \\
\hline Gastronomia & 6,61 \\
\hline Clima & 6,25 \\
\hline Tranquilidade da Cidade de João Pessoa & 5,41 \\
\hline Belezas naturais & 3,72 \\
\hline Pontos turísticos & 3,04 \\
\hline Praias do litoral sul & 2,53 \\
\hline Praia de Coqueirinho & 2,20 \\
\hline Programação cultural & 2,03 \\
\hline Organizaço da Cidade de João Pessoa & 1,86 \\
\hline Pôr do sol em Jacaré & 1,69 \\
\hline Praia de Tambaba & 1,52 \\
\hline Beleza da Cidade de João Pessoa & 1,18 \\
\hline Artesanato paraibano & 1,18 \\
\hline Rever amigos ou familiares & 0,84 \\
\hline Areia vermelha & 0,84 \\
\hline Segurança pública & 0,84 \\
\hline Orla de Tambaú & 0,51 \\
\hline Comércio & 0,51 \\
\hline Cultura regional & 0,51 \\
\hline Limpeza na cidade de João Pessoa & 0,51 \\
\hline Picãozinho das praias da RMJP & 0,51 \\
\hline Estrutura para receber o turista & 0,34 \\
\hline Ns/Nr & 0,84 \\
\hline Fonte: & \\
\hline
\end{tabular}

Fonte: IFEP (2014)

Quanto às praias preferidas pelos turistas e consideradas como o principal atrativo turístico da cidade foram citadas a Praia de Tambaú com 84,5\% da preferência, e o Cabo Branco com 78,83\%, e, na sequência, as praias de Manaíra (48,71\%), Coqueirinho (40,10\%), Bessa (35,97\%), Cabedelo (30,46\%) e Tambaba $(26,68 \%)$.

Por outro lado, foi solicitado também que os turistas citassem os "pontos negativos" ou os "aspectos" de que menos gostaram na viagem. Dentre os mais citados, elencados na tabela 7, estão a "Falta qualificação dos garçons" (22,63\%), a "Falta de 
campanha educativa para que as pessoas não joguem lixo nas areias das praias e no chão" $(18,54 \%)$, "Poucas placas de informação turística" (16,31\%), "Pouco policiamento nos pontos turísticos, praias do litoral sul, centro de João Pessoa e nos eventos da orla marítima" (15,55\%) e "Sinal fraco das operadoras de telefonia móvel" $(14,27 \%)$.

\section{Tabela 7}

Pesquisa Anual do Desempenho do Turismo na Região Metropolitana de João Pessoa 2014

Distribuição da amostra segundo os pontos negativos citados pelos turistas na Paraiba

\begin{tabular}{|c|c|}
\hline PONTOS NEGATIVOS CITADOS & PERCENTUAL \\
\hline A falta de qualificação dos garçons em alguns restaurantes e bares & 22,63 \\
\hline $\begin{array}{l}\text { Falta de campanha educativa para que as pessoas não joguem lixo nas areias das } \\
\text { praias e no chão, principalmente, em época de maior fluxo turístico }\end{array}$ & 18,54 \\
\hline Poucas placas de informação turística & 16,31 \\
\hline $\begin{array}{l}\text { Pouco policiamento nos pontos turísticos, praias do litoral sul, centro de JP e nos } \\
\text { eventos da orla marítima de acordo com a quantidade de pessoas }\end{array}$ & 15,55 \\
\hline Sinal fraco das operadoras de telefonia móvel & 14,27 \\
\hline Aeroporto pequeno para receber os turistas na alta estação & 12,94 \\
\hline Preços elevados cobrados aos turistas nos hotéis, bares, restaurantes, comércio e taxis & 10,58 \\
\hline Atendimento muito lento nos bares e restaurantes & 9,90 \\
\hline Pouca opção de diversão noturna & 9,30 \\
\hline $\begin{array}{l}\text { Sujeira em algumas ruas de João Pessoa, principalmente, na lagoa e próximo ao } \\
\text { terminal rodoviário de João Pessoa }\end{array}$ & 8,94 \\
\hline Lixo na areia das praias & 8,16 \\
\hline Transporte público lotado e tempo de espera longo nas paradas & 7,77 \\
\hline Número elevado de pedintes na Praia de Tambaú & 6,27 \\
\hline Falta placa de informação indicando a Praia de Jacaré & 6,23 \\
\hline Pouco estacionamento nas praias de João Pessoa e nos pontos turísticos & 6,16 \\
\hline Rodoviária precisando de reforma & 5,83 \\
\hline Atendimento demorado no aeroporto e na rodoviária, principalmente, para os idosos & 4,94 \\
\hline Falta de banheiros públicos nas praias de João Pessoa e do litoral sul & 3,97 \\
\hline Trânsito desorganizado & 2,52 \\
\hline Falta de respeito à faixa de pedestre & 2,33 \\
\hline Aumento da violência em João Pessoa & 2,14 \\
\hline Frota de táxi pequena para atender um maior número de turista na RMJP & 2,14 \\
\hline Falta diversão noturna durante a semana & 1,94 \\
\hline Falta de salva-vidas nas praias do litoral sul & 1,78 \\
\hline Pouca divulgação dos pontos turísticos do Estado da Paraíba em outros estados & 1,75 \\
\hline Melhorar sinalização urbana nos bairros & 1,75 \\
\hline Forte de Cabedelo abandonado & 1,55 \\
\hline Atendimento demorado no comércio & 1,36 \\
\hline Melhorar iluminação na rodoviária & 1,36 \\
\hline Falta de qualificação dos taxistas da RMJP & 0,97 \\
\hline Aumentar pontos de informação turística & 0,78 \\
\hline Clima quente & 0,78 \\
\hline Pouco investimento em segurança pública & 0,58 \\
\hline Falta salva-vidas nas praias da RMJP & 0,58 \\
\hline Falta de chuveiro nas praias da RMJP & 0,39 \\
\hline Ausência de placas informando nome das praias & 0,39 \\
\hline Melhorar a qualificação das pessoas que trabalham com o turismo & 0,39 \\
\hline Nenhum ponto negativo & 17,86 \\
\hline $\mathrm{Ns} / \mathrm{Nr}$ & 5,24 \\
\hline
\end{tabular}

Fonte: IFEP (2014) 
Além da Região Metropolitana de João Pessoa, os turistas visitaram também outras cidades do interior, sendo Campina Grande a mais visitada com 47,37\%, seguida de Patos $(9,77)$, Guarabira (7,52\%), Souza (6,02\%), Areia (5,26\%), Cajazeiras, Solânea e Bananeiras, cada uma com $4,51 \%$ de visitas.

Segundo estimativas e inferências sobre o turismo doméstico no Brasil, atualmente cerca de metade da população do país realizou pelo menos uma viagem em 2011. Este estudo inclui de forma direta a cidade de João Pessoa nas estimativas, pois foi realizado nas capitais e principais cidades do país. A mesma pesquisa revelou também que, a variável renda mensal interfere no número de pessoas que viajam por domicílio, ou seja, quanto maior a renda, maior é a porcentagem de viajantes por domicílio.

O Nordeste se apresenta em primeiro lugar como a Região possuidora dos principais destinos turísticos mais desejados (54,2\%), seguido pelo Sudeste com (20,4\%). A posição geográfica relativa entre o lugar de origem e o destino turístico é a variável que mais interfere na escolha do destino pelo turista, sendo que $70 \%$ dos fluxos ocorrem dentro das próprias Regiões. Isto explica o porquê das localidades apresentarem uma maior visitação de público local. Essa mesma predominância foi registrada também entre os Estados, com 51\% dos fluxos interno de turistas (BRASIL, 2012).

Analisando a Paraíba no contexto do turismo brasileiro, constatamos que, a mesma não se configura como um Estado que interfere de forma significativa nos dados e estatísticas ligadas ao turismo de outros Estados do Nordeste e de outras Regiões, nem no que diz respeito à variável "emissores de turistas", nem na variável "valor dos gastos/Receitas".

Percebemos que, para nenhum Estado das Regiões Sul e Sudeste, a Paraíba aparece entre os principais emissores de turistas, nem entre os principais geradores de receitas. Com exceção dos Estados do Nordeste, a Paraíba aparece no rol dos principais emissores de turistas e geradores de receitas apenas para o Pará e o Distrito Federal, como podemos visualizar nos gráficos 6 e 7 .

No gráfico 7, dos principais geradores de receitas para o Distrito Federal, podemos perceber que a Paraíba não aparece como um dos Estados que contribuem com receitas, apesar de ser um dos que contribuem com a emissão de turistas para o DF. 
No Nordeste a Paraíba é citada como um dos principais emissores de turistas e geradores de gastos apenas para os Estados do Ceará, Pernambuco, Rio Grande do Norte e para o próprio Estado da Paraíba, conforme os dados dos gráficos 8, 9 e 10 .

Confirmando a tendência ${ }^{12}$, a Paraíba se apresenta como o Estado que mais contribui com turistas para os dois Estados mais próximos geograficamente, Rio Grande do Norte e Pernambuco. O contrário também acontece quando consideramos a Paraíba, como percebemos no gráfico 11, onde os dois estados que mais contribuem com a emissão turistas para a Paraíba são, além de São Paulo, o Rio Grande do Norte e Pernambuco. Vale destacar que São Paulo só não aparece no rol dos principais emissores de turistas e geradores de receitas para os estados de Roraima, Amapá e Acre.

\footnotetext{
${ }^{12}$ A posição geográfica relativa entre o lugar de origem e o destino turístico é a variável que mais interfere na emissão de turistas.
} 


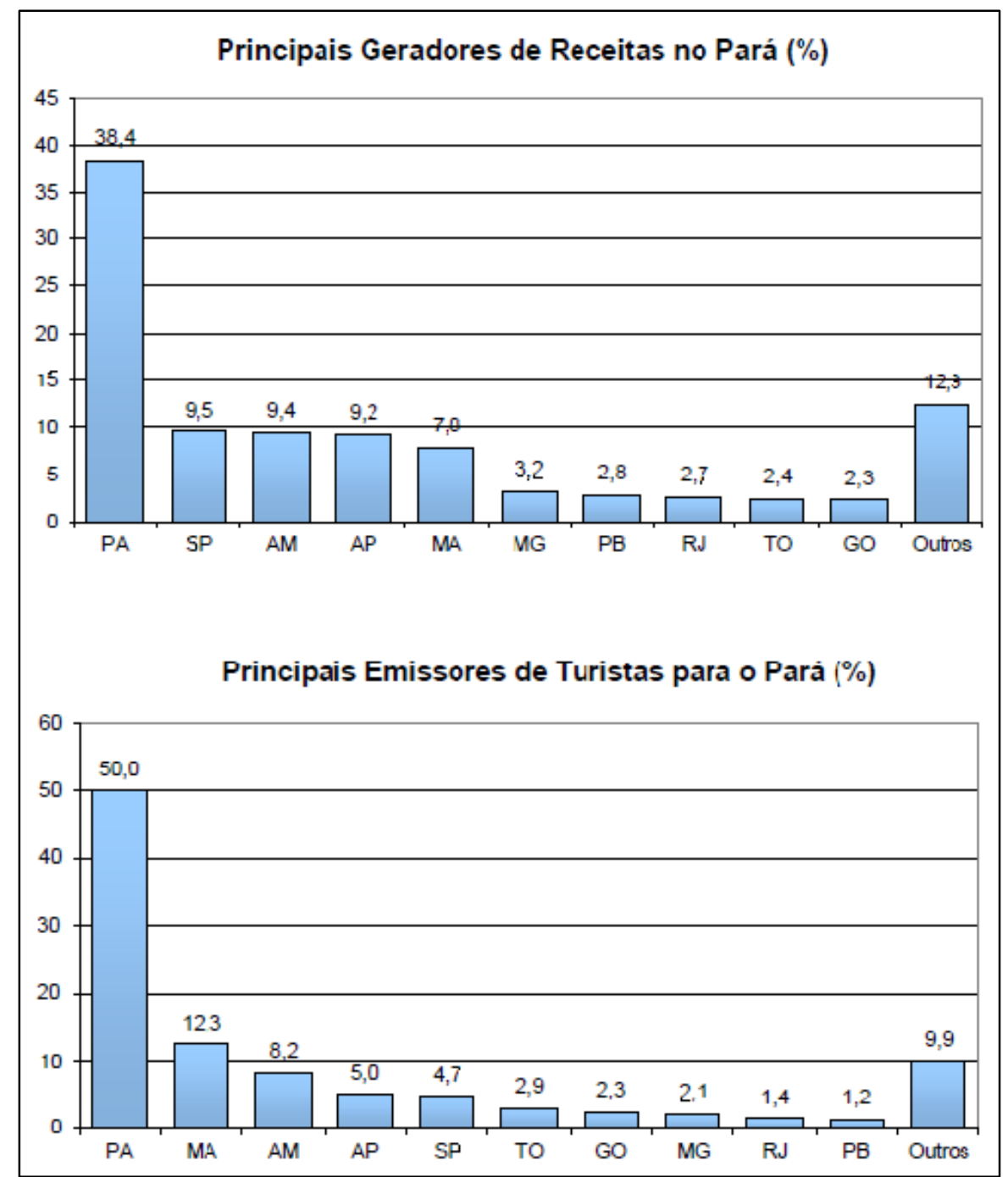

Gráfico 6 - Principais emissores de turistas e principais geradores de receitas no Pará.

Fonte: Ministério do Turismo (BRASIL, 2012) 


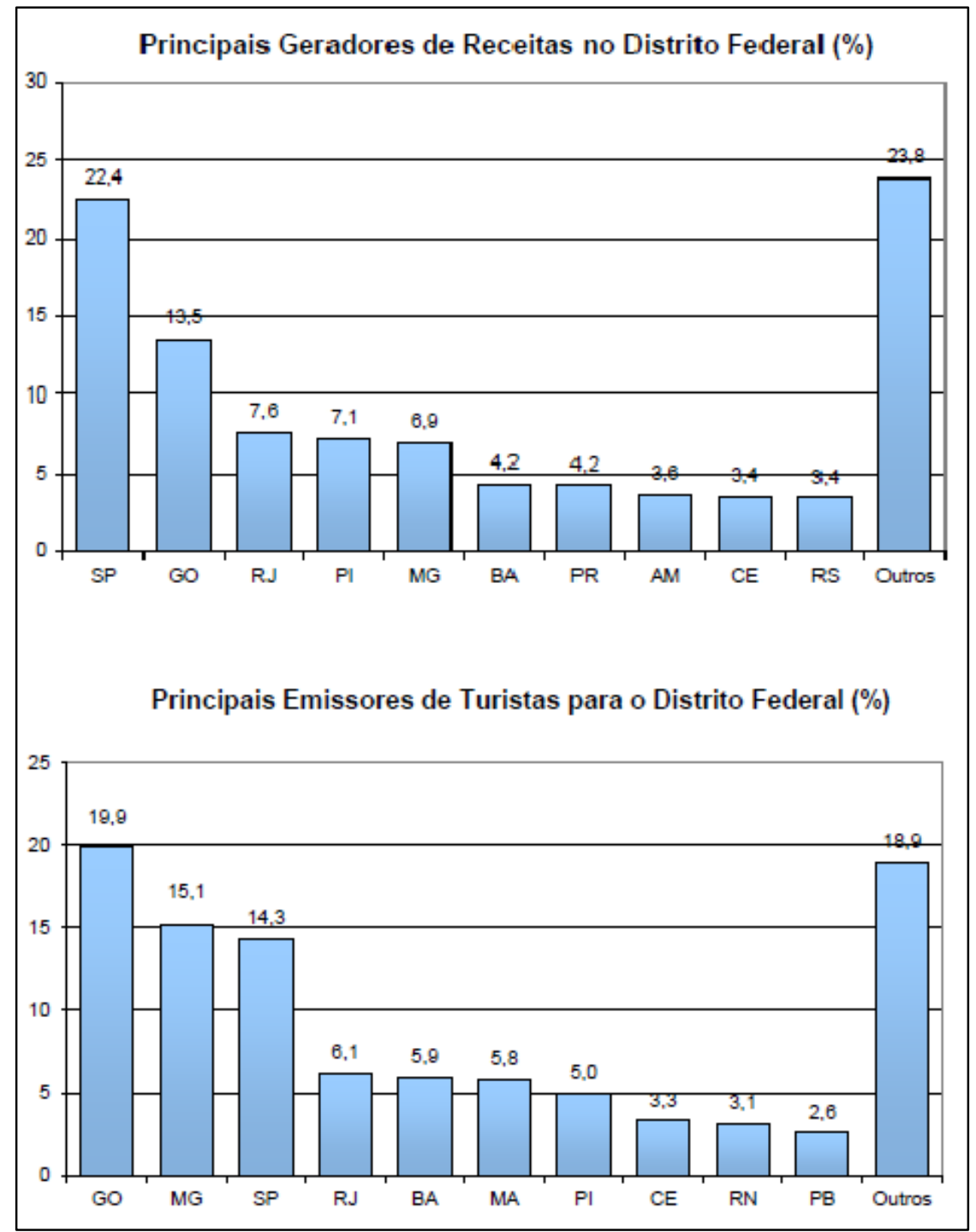

Gráfico 7 - Principais emissores de turistas e principais geradores de receitas para o Distrito Federal

Fonte: Ministério do Turismo (BRASIL, 2012) 


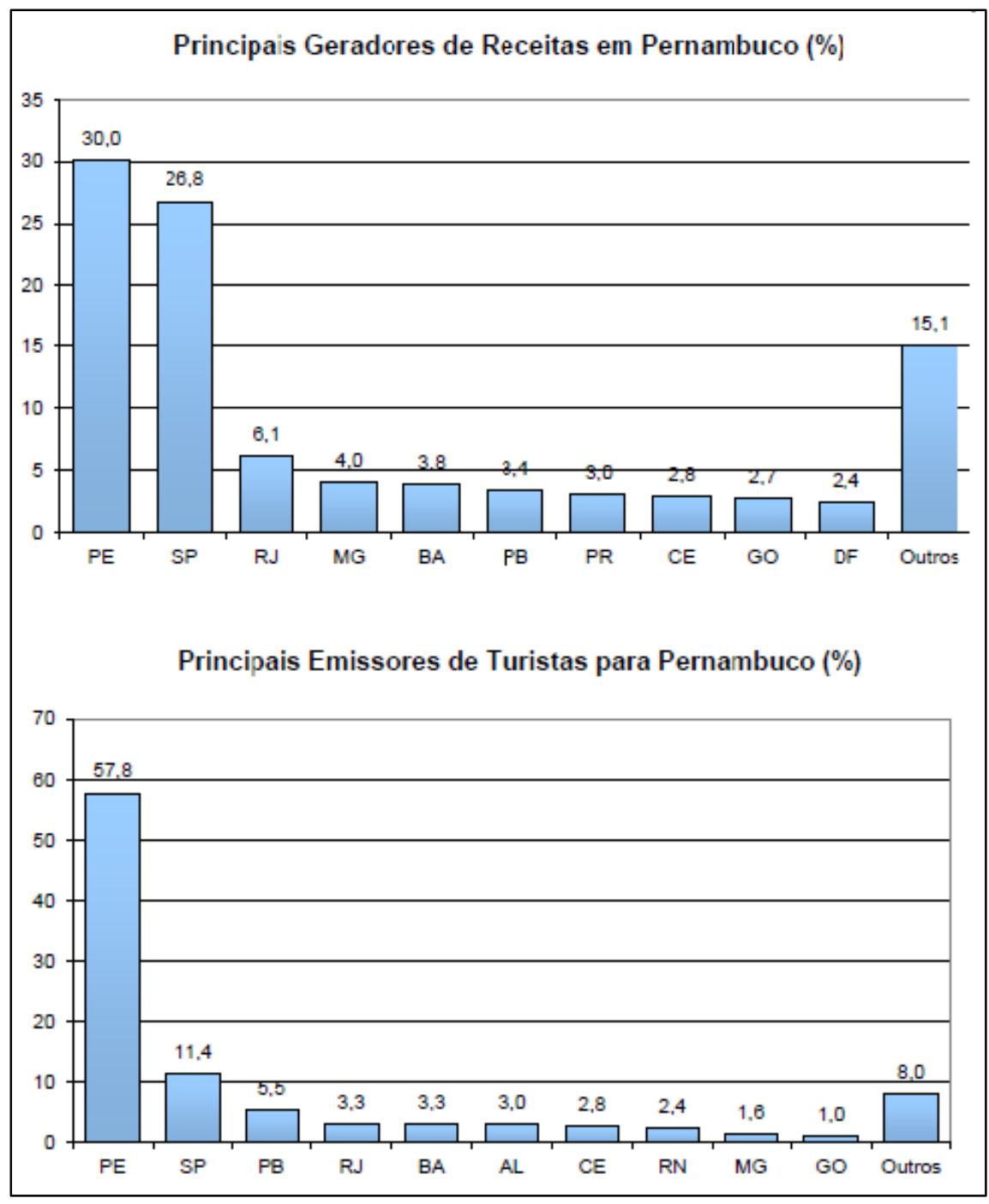

Gráfico 8 - Principais Emissores de Turistas e Principais Geradores de Receitas para Pernambuco.

Fonte: Ministério do Turismo (BRASIL, 2012) 
Principais Geradores de Receitas no R. G. do Norte (\%)

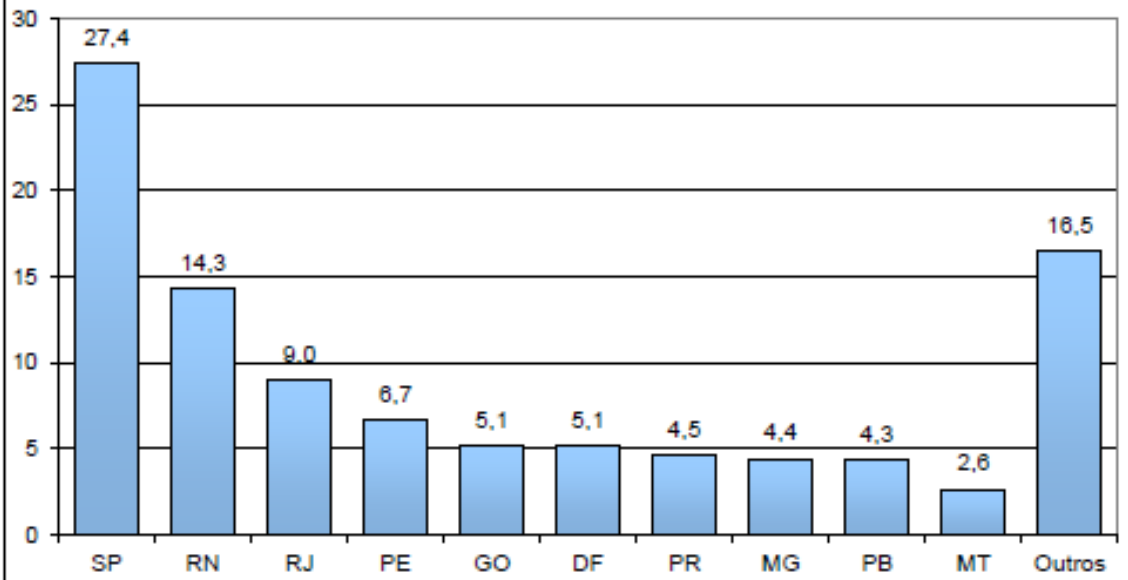

Principais Emissores de Turistas para o R. G. do Norte (\%)

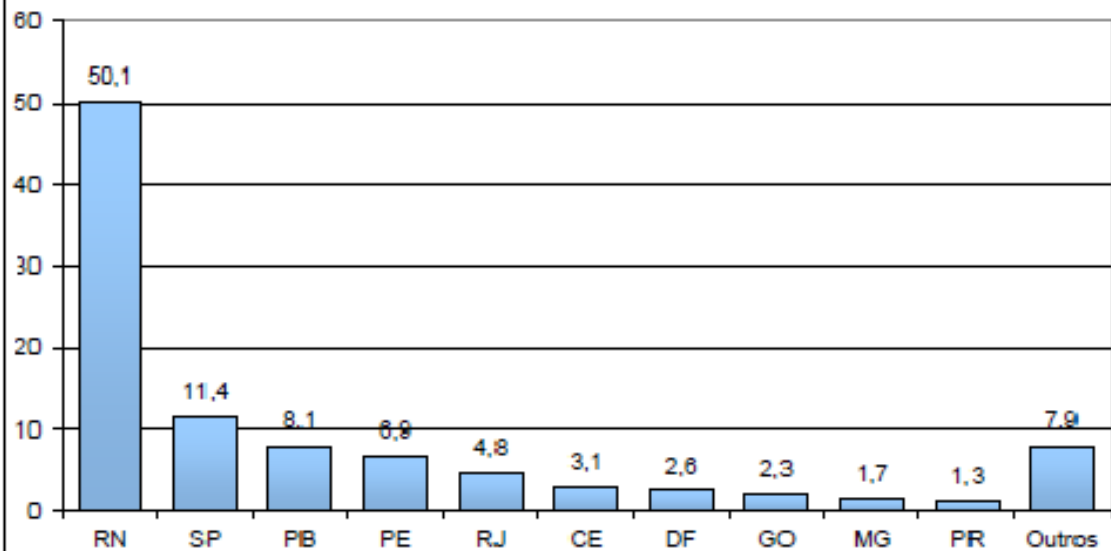

Gráfico 9 - Principais Emissores de Turistas e Principais Geradores de Receitas para o R. G. do Norte.

Fonte: Ministério do Turismo (BRASIL, 2012) 


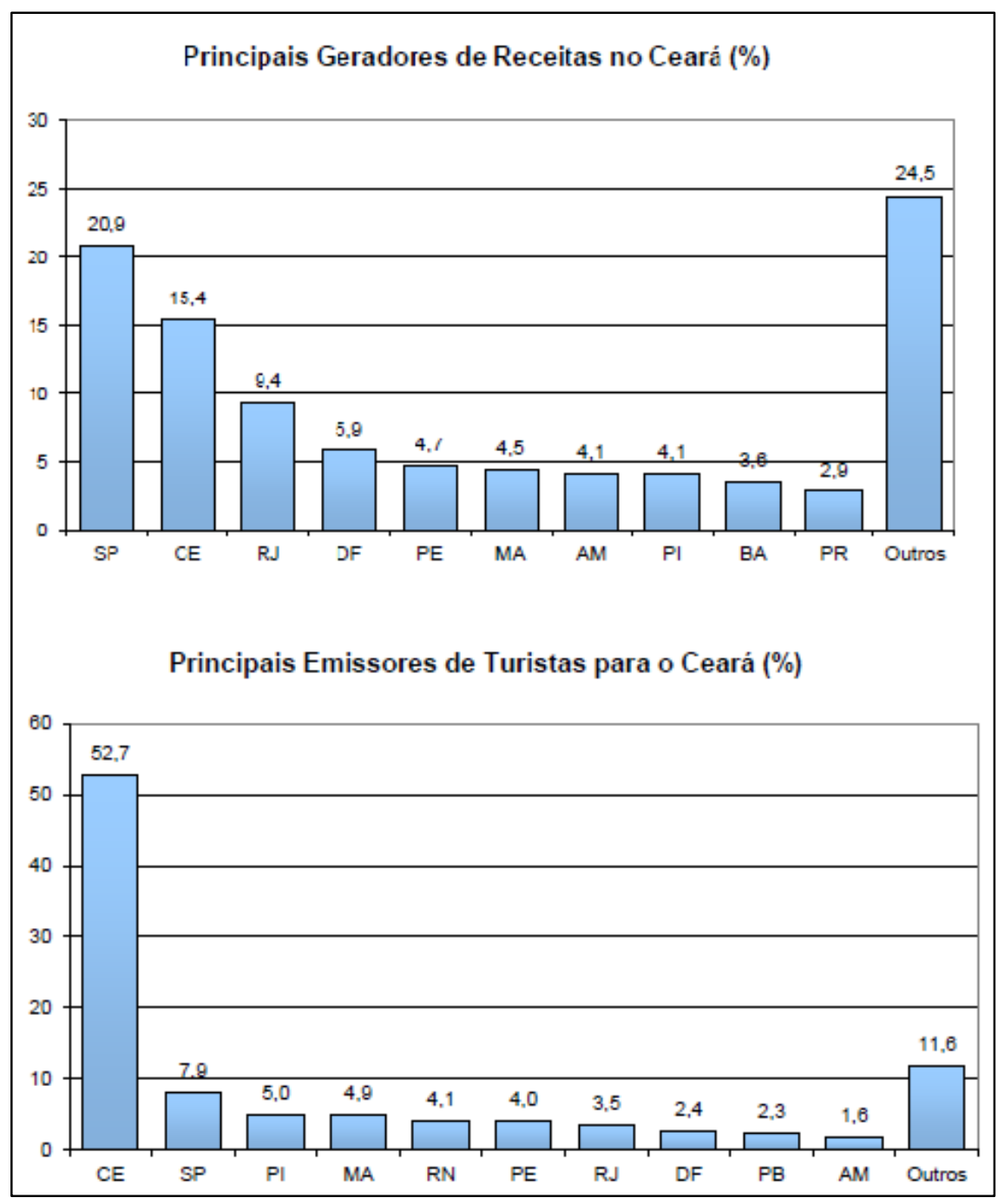

Gráfico 10 - Principais Emissores de Turistas e Principais Geradores de Receitas para o Ceará.

Fonte: Ministério do Turismo (BRASIL, 2012) 


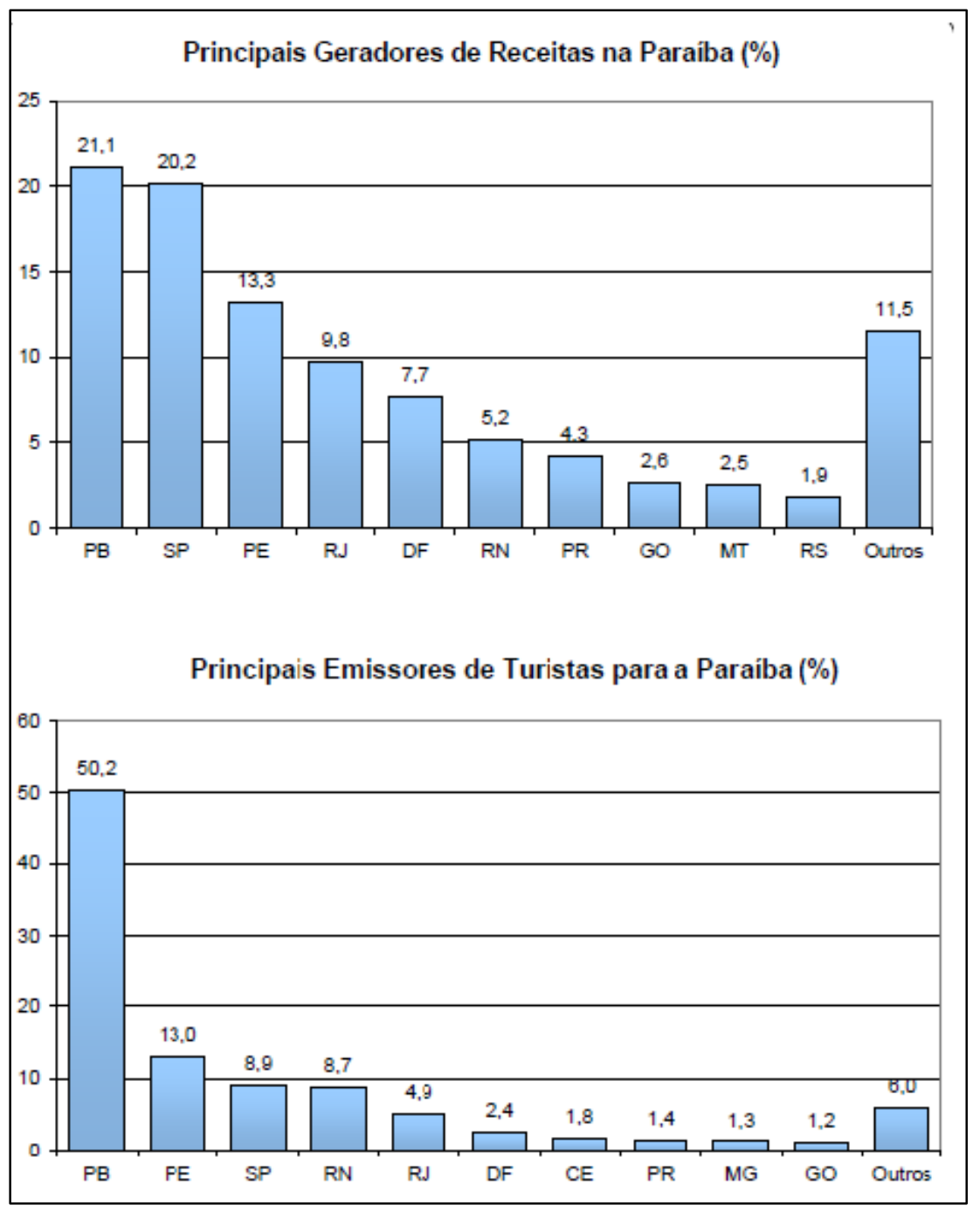

Gráfico 11 - Principais Emissores de Turistas e Principais Geradores de Receitas para a Paraíba.

Fonte: Ministério do Turismo (BRASIL, 2012) 


\section{4 - Turismo como influência na produção do espaço em João Pessoa}

Grandes transformações ocorridas na sociedade moderna ocasionaram avanços tecnológicos com o aumento da produção industrial e o crescimento econômico. O espaço como um todo sofreu transformações impulsionadas pelas novas tecnologias e pelas novidades informacionais. O mundo da mercadoria se ampliou de forma que modificou substancialmente as cidades através da industrialização e da circulação de seus produtos. Com isto, a cidade cresceu, se expandiu e iniciou um complexo processo de urbanização. Ao mesmo tempo em que a cidade se transforma, a sociedade também entra numa metamorfose que a torna cada vez mais urbana.

Dentro deste contexto, Lefebvre (1999) propõe, para esta sociedade, que nasce no período industrial e o sucede, a denominação de sociedade urbana, conceito que designaria um fato ainda não consumado enquanto realidade. Para o autor, a sociedade urbana seria mais uma tendência ou possibilidade futura. Para Lefebvre (1999) cada vez mais as transformações e avanços da sociedade atual a tem levado a se distanciar do mundo agrário e a se aproximar predominantemente das questões relativas à problemática urbana.

A atividade turística se enquadra como uma questão urbana a partir do momento em que é uma atividade econômica nascida no seio desta sociedade urbana proposta por

Lefebvre. É, portanto, uma prática social (CRUZ, 2003) constituída de forma complexa num novo contexto urbano, mas associando elementos herdados do período industrial. Estas considerações nos levam a inferir que, mesmo que a atividade turística seja realizada em espaços rurais ou onde predominam aspectos da natureza, como em atividades de turismo rural ou de aventura, o turismo é essencialmente urbano.

Como fenômeno essencialmente urbano, constituído num âmbito capitalista do mundo da mercadoria, a singularidade do turismo se concentra em seu objeto de consumo, o espaço geográfico. Este espaço não se constitui como mercadoria acabada e pronta, mas em constante produção e reprodução de acordo com a dinâmica social. Um espaço turístico é aquele em que a sua produção e reprodução se dão preponderantemente em função da atividade do turismo, sendo esta atividade a mais relevante dentre as outras na produção deste espaço. Moraes (1987) reitera que a produção do espaço é histórica e social e se dá através da realização do trabalho, bem como das múltiplas relações que se 
estabelecem entre os diversos atores sociais e dentro das condições do modo de produção vigente.

Mesmo sendo possível de ser produzido, o espaço não deve ser confundido com outros objetos comuns da produção material, pois, além de ser um produto resultante de trabalho social ele é também "uma condição geral da produção e da existência humana" (MORAES, 1987, p. 132). Portanto, o espaço pode ser considerado um objeto complexo e múltiplo e esta complexidade foi muito bem explicitada por Santos $(1993,1997)$ quando refletiu sobre a natureza deste espaço como sendo "um conjunto indissociável, solidário e também contraditório, de sistemas de objetos e sistemas de ações, não considerados isoladamente, mas como o quadro único no qual a história se dá” (SANTOS, 1997, p. 51).

Para a realização de suas necessidades, a atividade do turismo impõe a produção de um espaço destinado especificamente a um tipo de uso que é diferente do uso cotidiano das populações locais e, ao mesmo tempo em que se fala em produção, se fala também em um consumo deste espaço. O turista é o principal agente desta atividade, sem ele não há demanda para a produção e não há o consumo deste espaço. O turista seria o trabalhador que consome o seu tempo livre a serviço do capital, que vem cada vez mais produzindo e reproduzindo um espaço sob medida para a realização deste consumo.

Assim, a atividade turística promove a (re)produção de um espaço sob encomenda de acordo com um modelo idealizado. Os elementos já existentes neste espaço podem ser ressignificados para dar conta de uma nova demanda, agora dos novos usuários, os turistas. Os novos desejos e as novas expectativas do turista com relação ao espaço trazem também a refuncionalização de antigas estruturas

Esta reconstrução planejada de um espaço pré existente é agora a representação do espaço original. Espaço planejado e construído com forte apelo estético, artificialmente pensado como cenário de um espetáculo (a ser representado e não mais vivido pelas populações locais) a ser assistido pelos novos consumidores ávidos por consumir o mais novo produto deste, e neste espaço.

Ao mesmo tempo em que se fala em produção do espaço, traz-se à tona também a questão do consumo deste espaço como uma mercadoria carregada de um valor, que pode ser um valor material (do ponto de vista físico, arquitetônico ou natural) ou um valor 
simbólico (culinária, cultura, eventos, festas). Evidentemente que estes dois tipos de valores podem estar associados a um mesmo espaço.

Entretanto, para que se compreenda bem a questão é necessário diferenciar as duas categorias valorização e valoração. A valorização de um espaço está diretamente ligada ao seu valor material, cuja concepção de valor está explícita em Marx (MORAES, 1987). A valoração, por sua vez, está associada a uma noção psicológica e cultural de indivíduos e grupos de fazer juízo estético, ético e moral de algo. Neste mesmo raciocínio Rodrigues (2002, p. 56) entende que o turismo é uma atividade que produz um espaço, e mesmo quando não o modifica materialmente, valora este espaço através de "demarcações simbólicas" ou apropriações simbólicas e culturais. É importante que se compreenda também que, tanto a valorização, quanto a valoração dos espaços turísticos são categorias que estão ligadas diretamente à lógica do capital que induz e produz a atividade turística.

Com isso Moraes (1987) afirma que não existe espaço que esteja fora da lógica do capital, salientando que, em qualquer época e em qualquer lugar, todas as sociedades valorizam o espaço e a forma desta valorização é definida de acordo com o modo de produção vigente.

Fazendo uma reflexão acerca da concepção de Marx sobre o papel da determinação econômica no movimento da totalidade social o autor afirma que:

Para Marx, o valor é, antes de tudo, uma categoria social. Não há valor
sem trabalho. Concebe-o em seu duplo significado: valor de uso e valor
de troca. O primeiro expressa a substância mesma do valor, o seu
fundamento material. Ele exprime a utilidade dos produtos para a
satisfação das necessidades humanas, sendo a materialização mesma do
trabalho humano. [...] Neste sentido, a história humana, até o advento
do capitalismo, é marcada basicamente pela produção de valores de uso.
Com a intensificação do comércio e da produção de mercadorias, a
ênfase passará a ser a produção de valores de troca [...] este,
fundamenta-se na utilidade do produto para consumo alheio, o que o
torna apto à troca (MORAES, 1987, p. 110-111).

Na concepção marxista o valor de um produto se expressa pela quantidade de trabalho despendida na sua produção. O trabalho então passa a ser a medida real do valor, onde o espaço é, antes de tudo, o palco da realização do trabalho e da produção. Com isso, o processo de valorização do espaço não advém apenas de inerências do espaço, mas, é sempre a sociedade que o qualifica a partir de suas qualidades naturais (inerentes) e de qualidades artificiais resultantes do trabalho socialmente realizado. Sob o ponto de 
vista do capitalismo a valorização do espaço se dá através de uma composição feita com o valor intrínseco próprio da natureza do espaço e de seu valor agregado por obras do trabalho social realizado, materializado e acumulado sobre o espaço.

Desta maneira, a relação da sociedade com o espaço material é mediada pelo trabalho, pois, "não existe o ser social sem trabalho", assim como, "não existe trabalho sem criação de valor" (MORAES, 1987, p. 116). Desta forma, se o trabalho social cria valor e, segundo o autor, o espaço é a condição prévia necessária para a realização do trabalho, a apropriação deste espaço de produção precede a sua valorização. Portanto, podemos falar de uma territorialização do valor, a partir da apropriação do espaço e da espacialização do trabalho social.

O turismo, enquanto atividade social, produz, valora e valoriza o espaço que agora se torna um território turístico, sendo especialmente desejado como um destino a ser apropriado, tanto em sua forma física como simbólica. Esse processo ocorre dentro de um contexto social e cultural cujo alcance se dá do local ao global. Assim, criam-se e recriamse novos espaços sobre antigos espaços através da produção de novas mercadorias, mesmo que simbólicas. Como afirma Rodrigues (2002, p. 58), “se a atividade 'turismo' não é nova, a forma de produzir estes espaços é tecnologicamente mais arrojada e moderna".

Neste sentido, na produção deste novo espaço, modificado através de valores agregados e voltado às atividades de turismo, cria-se um espaço territorializado para o turismo. Quando se diz apropriação do espaço se pode falar também na apropriação de aspectos intangíveis ligados ao espaço como os bens culturais, que são transformados em mercadoria, podendo ser adaptados aos novos gostos e preferências. Becker (2002), neste sentido, fala de uma valorização seletiva de pontos do espaço em função de suas características (naturais ou artificiais) próprias.

Moraes (1987) fala em "colonização moderna" ao pensar nas novas formas de apropriação e produção do espaço. Essas novas formas se diferenciam das de antes, porque agora incorporam não mais espaços inexplorados, mas novos espaços ressignificados e refuncionalizados, ao circuito do capital. Esta nova forma de integração se faz "em termos da intensidade da valorização" (MORAES, 1987, p. 169). Essa forma diferenciada de produção do espaço potencializa a natureza conflituosa e contraditória do 
processo, pois age alterando o espaço natural ou construído, as relações de trabalho existentes e, consequentemente, as relações sociais já estabelecidas.

A partir do momento em que se fala de posse e apropriação é incorporado o conceito patrimônio nos processos referentes ao espaço, compreendendo-o como um complexo de bens, materiais ou não, direitos, ações, posse e tudo o mais que pertença a alguém ou a uma empresa e possa ser valorado. Toda a complexidade exposta acima para a composição de um patrimônio não poderia ocorrer fora de um contexto social de produção, portanto, "não há patrimônio, seja ele material ou imaterial, que não seja cultural" (CRUZ, 2012, p. 95). Um patrimônio cultural é, portanto, uma atribuição de valor conferida a algo, sendo que este valor é criado histórica e socialmente do acúmulo de vivências, experiências, contradições e conflitos. O valor é criado pela sociedade através do trabalho social realizado e parte destes valores vão ser agregados ao espaço, neste caso, formando um patrimônio.

Durante o processo de revalorização e refuncionalização de uma parcela do espaço, o valor de uso de um objeto é o que motiva a sua transformação em um patrimônio, mas seu valor de troca é o que o mantém como objeto carregado de valor e de importância. De acordo com a autora, muitos exemplos "ilustram o triunfo do valor de troca sobre o valor de uso no que diz respeito ao chamado "patrimônio cultural"” (CRUZ, 2012, p. 98).

O espaço, depois de apropriado, valorizado e valorado torna-se mercadoria pronta a ser comercializada, não sem antes ser reinventado de acordo com as especificações dos novos sujeitos interessados por consumir. Para o capitalismo o consumir está cada vez mais atrelado aos signos e significados que os objetos incorporam. Luchiari (2005), cita uma certa aceitação, para não dizer preferência, das pessoas pela artificialização da natureza e da cultura, onde a imitação e a simulação das coisas originais se tornam o espetáculo mais apreciado.

O projeto de captura da essência do lugar se dá através da reinvenção da vida deste lugar, reinventa-se a memória e o simbolismo transformando-os em capital cultural. $\mathrm{O}$ que antes era espontâneo e simples torna-se espetaculoso e padronizado, tudo "novo", "brilhoso" e "estilizado" como preferem os consumidores desta nova mercadoria turística. A produção da mais valia agora se dá através do resgate do trabalho morto, de um trabalho pretérito que serviu para acumular as riquezas materiais que agora geram o 
capital simbólico e cultural tão desejado. O trabalho vivo dá vida ao trabalho morto e o valoriza a partir de novas necessidades.

O turismo se apropria desse capital transformando-o em uma mercadoria, se beneficiando também dos recursos urbanos como base para a sua efetivação. Aos poucos, a memória das cidades passa a ser valorizada com a inclusão desses elementos, através de um resgate de sua historia, de seus lugares. Recriando-se partes desta cidade em um contexto totalmente diverso, no entanto, produtivo para o capital atual.

Em meio a uma crise generalizada que afetou as principais potencias mundiais, mais especificamente a crise do petróleo da década de 1970, verifica-se o início da decadência das cidades (CRUZ, 2012), sobretudo e primeiramente, as grandes, que passam a sofrer cortes de verbas e de investimentos públicos. A diminuição dos investimentos públicos causa uma mudança, rompendo o padrão de uma época de prosperidade das cidades que "vêem-se diante da necessidade de encontrar novos caminhos com vistas à sua manutenção no cada vez mais competitivo 'mercado de cidades"” (CRUZ, 2012, p. 101).

Esta retração de investimentos de capitais nas cidades também é discutida em Luchiari (2005) que cita a desindustrialização, a competitividade global e os recursos tecnológicos como elementos que influenciaram, em grande parte, as mudanças na organização, nos fluxos de produção e na infra-estrutura das cidades. Sobre esta crise geral Harvey (2005), cita uma erosão disseminada da base econômica e fiscal de muitas grandes cidades do mundo capitalista avançado. Fato que acaba por causar a transição do administrativismo urbano para o empreendedorismo urbano, em que a parceria públicoprivada é o elemento principal. Para o autor, "normalmente, o novo empreendedorismo urbano se apoia na parceria público-privada, enfocando o investimento e o desenvolvimento econômico, por meio da construção especulativa do lugar em vez da melhoria das condições num território específico, enquanto seu objetivo econômico imediato (ainda que não exclusivo)" (HARVEY, 2005, p. 174).

Todo este contexto de crise iniciado nas grandes cidades de capitalismo avançado se propaga e atinge as de capitalismo tardio, que passaram a ter que se adequar aos novos direcionamentos políticos e econômicos, como foi o caso das cidades brasileiras. Neste contexto, o turismo passa a ser considerado possibilidade promissora ocupando, a partir daí, um lugar de destaque nas políticas de geração de divisas de muitas cidades. Carvalho 
(2009) aborda a questão de uma disputa dentro do mercado turístico mundial, em que mais de 130 países se empenham em abarcar uma maior fatia deste mercado.

Tem se falado em mercados de cidades (CRUZ, 2012), consumo de cidades (LUCHIARI, 2005), consumo e venda do espaço (RODRIGUES, 2002) e tantas outras formas de pronunciar o espaço como produto. Não seria o caso de falar de uma hipoteca deste espaço? Já que, através do turismo, o espaço é colocado à venda, anunciado como oferta turística, mas sem a entrega definitiva de sua posse. Coloca-se o bem em questão, o espaço, à sujeição de uma transação de compra e venda em que não há transferência efetiva do bem ao comprador. O turista, como consumidor desse espaço, o concebe como um produto abstrato, como um direito de uso, ou usufruto. No turismo o espaço é vendido, mas não a sua estrutura física em si. O espaço é negociado através de um valor territorializado especialmente, mas não exclusivamente, para o turista.

Rodrigues (2002) aborda a venda do território sob duas perspectivas, a venda do natural (natureza) e a venda do passado histórico (arquitetura histórica, por exemplo). Na primeira, o espaço é vendido sob os argumentos de ser detentor de características naturais que o distinguem de outros e que são impossíveis de serem reproduzidas artificialmente. O frio, a neve, o sol, rios, o mar, lagos, relevos incomuns, montanhas, planaltos, cachoeiras, são alguns exemplos, mas as possibilidades são infinitas. A segunda perspectiva é a venda do espaço sob o pretexto de uma diferenciação histórica comumente ligada aos aspectos arquitetônicos e de patrimônio histórico e cultural. Em João Pessoa esses dois enfoques estão muito evidentes na concepção do turismo local, onde o espaço toma seu maior destaque em dois pólos principais de atuação turística, a faixa litorânea e o centro histórico.

$\mathrm{Na}$ cidade, o marco introdutório de um turismo empreendedor, de maior capacidade receptiva e voltado à transformação do espaço em função do capital, foi a construção do Hotel Tambaú ${ }^{13}$ em 1971. Sua construção à beira mar demarca simbolicamente a transferência da antiga referência de cidade colonial para uma cidade dos "novos tempos", eminentemente litorânea.

\footnotetext{
${ }^{13}$ Considerado até hoje como um símbolo do turismo na cidade, este hotel esteve vinculado inicialmente a um atrativo turístico que já foi muito importante na Paraíba nas décadas de 1960 e 1970, a pesca da baleia (LEAL, 2001).
} 
A partir de então iniciou-se em João Pessoa um lento processo de produção do espaço motivado essencialmente pelas novas perspectivas direcionadas à orla marítima da cidade. Neste momento outras intervenções afetaram sobremaneira o espaço da orla, que foi sendo induzido a manter-se com uma configuração horizontal, através da proibição de construções com mais de dois pavimentos. Esta restrição foi pensada e colocada em prática por meios legais ${ }^{14}$ para impedir que essas edificações interferissem na concepção paisagística do Hotel Tambaú (MOREIRA, 2006; LEAL, 2001).

Neste contexto no Brasil, diante das grandes transformações ocorridas entre as décadas de 1960 e 1970, de caráter político, econômico social e cultural, surge uma conjuntura que viabiliza a consolidação da atividade turística no país. No Brasil a criação da EMBRATUR, em 1966, inaugura a preocupação governamental com o desenvolvimento desta atividade econômica. Através da EMBRATUR desenvolve-se primeiro o turismo interno para, em seguida, o foco ser voltado para o turismo internacional (RODRIGUES, 2001). A política nacional do turismo foi pensada como um vetor de desenvolvimento e vem incidindo muito fortemente na zona costeira do país através de ações padrão consideradas estratégicas.

O Nordeste entra neste contexto como possibilidade de um fazer turístico que associa sol e mar, entretanto, a maioria dos estados costeiros desta região carece de um planejamento territorial voltado para suprir as necessidades da nova atividade. Os projetos turísticos como o PRODETUR e o PLANTUR foram instrumentos de desenvolvimento regional com a função principal de fazer a diversificação e a distribuição geográfica da infraestrutura necessária, até então concentrada no sul e sudeste do país. Ações como o desenvolvimento dos pólos de turismo integrados, que faziam verdadeiros corredores turísticos entre as cidades localizadas nas faixas litorâneas, integravam e incorporavam novas áreas aos roteiros turísticos, além da expansão da infraestrutura com novas estradas e aeroportos.

Estes projetos, parte integrante das políticas de turismo do país, foram, portanto, agentes importantes na mudança da feição urbana das cidades litorâneas nordestinas.

\footnotetext{
${ }^{14}$ Código Municipal de Urbanismo. Lei no 2.102 de 31 de dezembro de 1975.
} 
Transformou-se o espaço urbano nordestino com financiamentos do governo através de bancos como o Banco Interamericano de Desenvolvimento (BID) e o Banco Nacional de Desenvolvimento (BNDES) que viabilizaram créditos especiais para que a iniciativa privada investisse no setor.

Com o crescimento da atividade turística no Nordeste, impulsionada a partir das políticas de turismo para o país, aumenta a apropriação dos espaços pela atividade turística, principalmente os litorâneos, onde são construídas as infra estruturas necessárias à um público, agora consumidores, os turistas. $\mathrm{O}$ turismo passa a ser o principal agente de produção do espaço litorâneo regional e, consequentemente, também da cidade de João Pessoa, que por ter praias urbanas despoluídas, sol e calor o ano inteiro aumentava seu valor como um produto a ser consumido. A natureza da cidade, que há tempos proporcionava bons peixes, se converte agora de recurso à mercadoria. Cada vez mais se valorizam os espaços próximos à faixa litorânea para onde os empresários e as empresas turísticas têm voltado sua atenção incentivando uma valorização e uma valoração cada vez maior (MORAES, 2007).

O litoral também se particulariza, modernamente, por uma apropriação cultural que o identifica como um espaço de lazer, por excelência, e os espaços preservados são, hoje, ainda mais valorizados neste sentido. Isto sustenta uma das indústrias litorâneas de maior dinamismo na atualidade, qual seja a que serve às atividades turísticas e de veraneio. Identifica-se, assim, mais um campo onde a posição em tela apresenta, se não exclusividade, pelo menos uma grande favorabilidade locacional (MORAES, 2007).

Em João Pessoa a base necessária para a viabilização da produção do espaço nesta ótica foi implementada por ações coordenadas dos poderes públicos Federal, Estadual e Municipal, bem como da iniciativa privada, através dos empresários dos segmentos turístico, imobiliário e da construção civil. A produção deste espaço turístico tem como um dos principais efeitos na cidade o aumento dos preços da terra. Assim, terrenos que, em outras épocas, não eram de interesse para o turismo, passam a ter seu valor de troca aumentado. Este processo de valorização é fomentado por um forte apelo à imagem e à estética que transforma o espaço urbano litorâneo de João Pessoa em mercadoria de alto valor. 
Neste contexto, a capital paraibana se insere num modelo de produção do espaço para atender às demandas do turismo de sol e mar que predomina em toda área litorânea do nordeste. Segundo Barbosa (2005) muitas áreas que antes constituíam lugares de residência da população nativa passam a ser disputadas para a instalação de equipamentos turísticos. Ampliam-se, nos bairros privilegiados, próximo da orla marítima, a construção de prédios de alto padrão, hipermercados, shopping centers, e equipamentos para as necessidades dos turistas, como hotéis, restaurantes, locadoras de automóveis, agências de câmbio e de viagens.

Outras áreas menos urbanizadas da área litorânea da cidade também passam a ser incorporadas a esta lógica turística. Bairros como Altiplano Cabo Branco, Portal do Sol, Ponta do Seixas, Penha e Costa do Sol, localizados na parte sul do município, se configuram como área de expansão urbana bastante valorizada pela proximidade do mar. Vale salientar que são áreas que foram poupadas, durante a política habitacional efetivada entre o final dos anos de 1970 ao final dos anos de 1990, da construção dos conjuntos habitacionais de padrão mais popular, à exceção do conjunto habitacional do Altiplano Cabo Branco construído em 1978.

Barbosa (2005) estudou as transformações recentes que caracterizam a produção do espaço urbano no litoral sul de João Pessoa constatando a ocorrência de processos de segregação espacial e inclusão precária em grande parte desta área, gerando um processo de fragmentação essencialmente contraditória. Os condomínios fechados horizontais são os principais representantes das transformações que estão ocorrendo no litoral sul da cidade, que se caracteriza também por apresentar muitos fragmentos do seu espaço urbano constituídos por ocupações irregulares carentes de infra-estrutura e serviços urbanos básicos necessários para uma melhor qualidade de vida e maior eqüidade social.

Leandro (2006), ao estudar a construção da imagem da cidade de João Pessoa pelo enfoque das transformações urbanas viabilizadas pelo turismo, cita que

No primeiro mandato do governador Tarcísio Burity (1979-1982) foram realizadas importantes obras que atendem as atividades turísticas como o Espaço Cultural José Lins do Rego (1982) e a adoção de legislações direcionadas para áreas de interesse turístico. Por isso, valendo-se das prerrogativas da Constituição Estadual, Burity atribuiu poderes ao IPHAEP para disciplinar o uso do solo nas áreas de maior valor turístico: o Centro Histórico e a Orla Marítima. O Decreto 
Estadual 9.485 permitiu que o IPHAEP restringisse projetos de urbanização, construções e loteamentos realizados sem a autorização do órgão. Já o Decreto Estadual 9.484 instituiu o Centro Histórico de João Pessoa. (LEANDRO, 2006).

O Governo do Estado da Paraíba lança as bases legais para recebimento da infraestrutura dos mega projetos turísticos previstos para o Nordeste, que tinham como característica principal a participação efetiva do setor público evidenciada nos projetos estaduais como o Projeto Linha Verde (BA), o Prodeturis (CE), o Projeto Orla (SE), o Projeto Costa Dourada (PE-AL), O Projeto Parque das Dunas-Via costeira (RN), e o Projeto Cabo Branco (PB) (CRUZ, 1997).

Em João Pessoa, o Projeto Turístico do Cabo Branco teve como meta um complexo turístico e de lazer idealizado para uma área de 654 ha localizada entre a Praia da Penha e o Rio Cuiá, no litoral sul da cidade. Em sua infraestrutura está prevista a construção de 18 hotéis, unidades habitacionais, praças e áreas de lazer. No entanto, até o momento, desde a criação do projeto, a única ação realizada foi a construção do anel viário do Pólo Turístico.

Mesmo sem a continuidade do projeto esta mínima infraestrutura construída tem influenciado a urbanização turística do litoral sul da cidade. Com isto, facilitou-se o acesso às praias daquela área, aumentou o fluxo de veículos, houve uma expansão de loteamentos, residências, casas de veraneio, associações de lazer e condomínios horizontais fechados. Enfim, o litoral sul de João Pessoa, que se apresentava anteriormente como uma periferia urbana, ocupada por comunidades litorâneas pesqueiras (Penha e Jacarapé), é engolido pela lógica da especulação imobiliária por causa do processo de valorização acarretado pelas transformações.

O resultado tem sido uma crescente valorização do solo urbano causando novos padrões de uso e ocupação do solo e, com a instalação de residências de alto valor econômico nesta área da cidade. Barbosa (2005) demonstra uma valorização de 580\% em quatro anos, nos preços de lotes comercializados e localizados em bairros do litoral sul. Já em lotes localizados em condomínios fechados nesta mesma área, foi verificado um aumento de aproximadamente $1.500 \%$ quando comparado com o valor dos primeiros lotes comercializados na década de 1990 (BARBOSA, 2011). 
Atualmente esta valorização está sendo fomentada também pela construção do complexo da Estação Cabo Branco. Projetado por Oscar Niemayer, foi edificado pela Prefeitura Municipal em 2008, e se volta à realização de eventos artísticos, científicos e culturais. Está situado num local de grande referência simbólica para João Pessoa, a Ponta do Cabo Branco, próximo ao Farol do Cabo Branco e à Ponta do Seixas, como pode ser visto na Figura 1.

Outra intervenção estatal que vem se destacando no litoral sul da cidade é a construção do Centro de Convenções fazendo parte das ações que tentam deslanchar o Pólo Turístico do Cabo Branco, desta feita como estratégia para viabilizar o turismo de eventos na cidade.

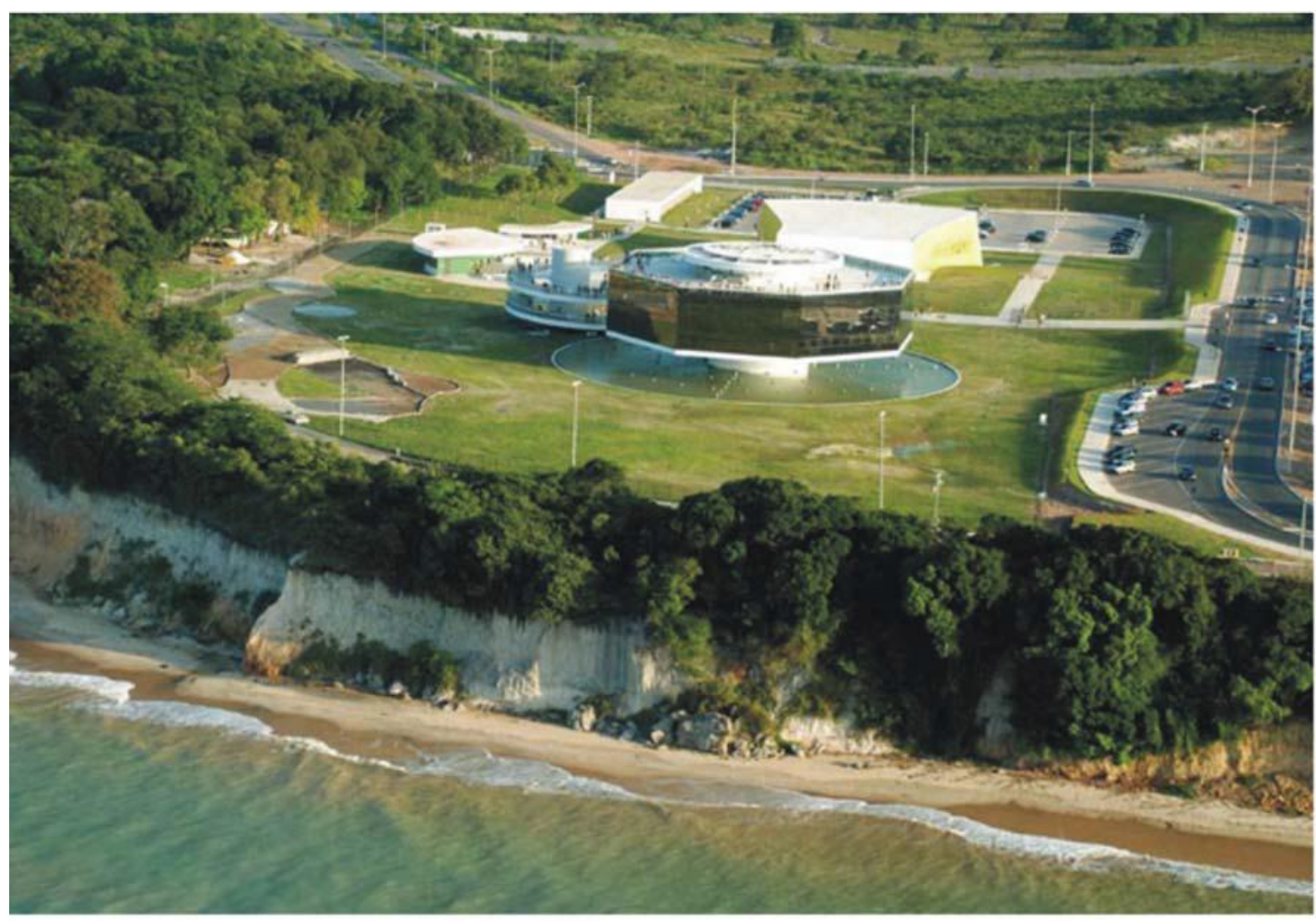

Figura 1 - Vista aérea da Estação Cabo Branco

Fonte: Prefeitura Municipal de João Pessoa, 2010.

A modernização do espaço turístico pessoense se efetiva através da construção de empreendimentos turísticos de natureza estatal, bem como de empreendimentos da iniciativa privada, especialmente de shoppings, hotéis e condomínios fechados de alto padrão. A construção da Estação Cabo Branco e do Centro de Convenções valoriza ainda mais este espaço no sentido de serem grandes construções de importância arquitetônica que o valorizam pelo forte apelo à imagem e à estética. Neste sentido, a capital paraibana vem mantendo o modelo de desenvolvimento do turismo de sol e mar. 
Contudo, tenta agregar valor ao espaço inovando o foco dos investimentos públicos agora para a vertente do turismo de eventos, o que sinaliza a manutenção da dependência das ações do Estado para construir e viabilizar as bases dos projetos de desenvolvimento do turismo. Para se enquadrar no modelo atual de turismo João Pessoa é chamada a se modernizar e a se adequar no novo modelo de mercado onde o seu espaço torna-se a principal mercadoria.

O modelo de turismo concebido para o Nordeste pelo governo seguiu a linha de "Turismo de sol e mar", voltado para grandes contingentes de turistas (turismo de massa), tendo como base de sua concepção os aspectos naturais dos espaços. O litoral foi o espaço privilegiado para implementação das ações do projeto.

Ao analisar o processo de viabilização dos Megaprojetos de João Pessoa (Cabo Branco), do Costa Dourada em Pernambuco e o projeto Parque das Dunas Via-costeira, em Natal, Souza Júnior e Ito (2005), identificaram grandes diferenciações em seus espaços resultantes do processo de implantação desses projetos.

Os autores destacam que, enquanto as outras duas capitais fizeram grandes investimentos na infraestrutura para viabilizar o turismo, em João Pessoa pouco se fez. O resultado é a manutenção, nesta cidade, de uma significativa parcela de aspectos naturais, como áreas verdes urbanas em forma de reservas em áreas próximas à orla, (principalmente próximas às praias de Cabo Branco e de Ponta de Seixas) com baixa densidade de ocupação, como pode ser visto na figura 2 .

Por outro lado, a sua atividade turística tem se mantido com pouca expressividade, tanto no que se refere à cidade como emissora/receptora de receitas, como emissora/receptora de turistas. 


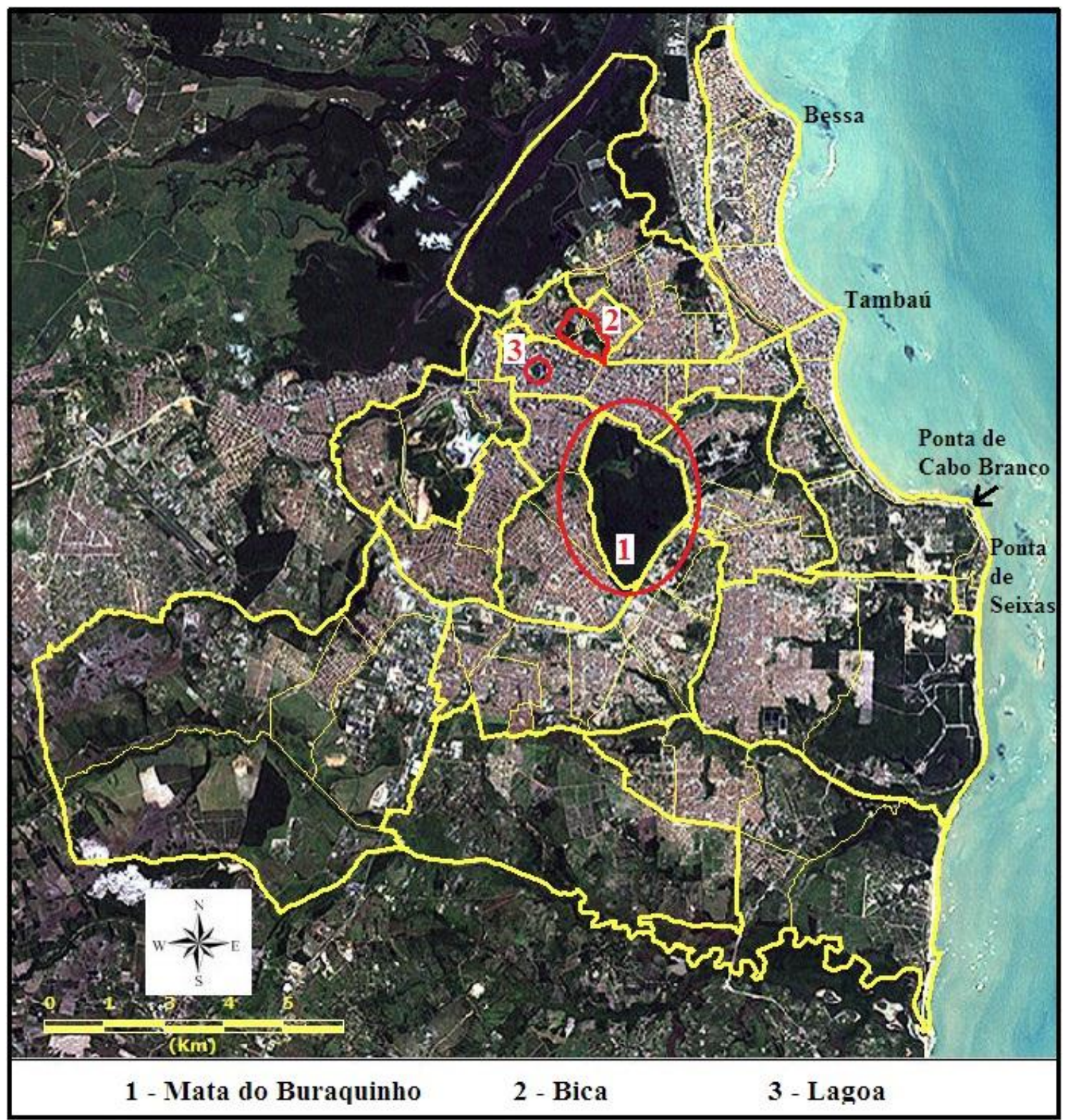

Figura 2 - Imagem de satélite da cidade de João Pessoa. Destaque para a Mata do Buraquinho, a Lagoa do Parque Sólon de Lucena e a o Parque Arruda Câmara, a Bica. Imagem ETM LANDSAT, bandas 3(R) 2 (G) 1 (B) e IHS ou banca 543 e 8. Fonte: SPOSATI (2009).

As contradições e conflitos de que falam vários autores (LUCHIARI, 2005; CRUZ, 2006, 2012; RODRIGUES, 2002) quando se referem ao processo de produção do espaço a partir do turismo se evidenciam na cidade de João Pessoa fortemente marcados por embates entre os mais diversos atores da sociedade (sociedade civil, administradores públicos, políticos, proprietários capitalistas).

As divergências entre os atores sociais reportam já à década de 1970, desde a primeira iniciativa de inclusão, no Código de Urbanismo da cidade, da restrição do 
gabarito urbano da orla, norma que, desde então tem sofrido, historicamente, diversas tentativas de eliminação.

Verificamos uma contradição posta, pois se pensarmos que um dos aspectos mais valorizados pelo turismo têm sido os aspectos ligados à natureza, então a cidade de João Pessoa e sua Região Metropolitana teria, de forma satisfatória, os principais requisitos necessários para um turismo mais expressivo em termos quantitativos. No entanto, o que temos visto é um turismo com pouca expressividade como já mencionado anteriormente. Assim, a reprodução do capital turístico na cidade de João Pessoa tem se dado de maneira incompleta, numa velocidade muito aquém das outras cidades de mesmo porte do litoral brasileiro, que apresentam processos de exploração turística num ritmo mais acelerado.

Casos como os de cidades vizinhas como Recife e Natal (com a forte presença de segregação, especulação e acumulação) nos fazem pensar sobre a realidade do espaço urbano de João Pessoa, que parece ser uma última fronteira de um espaço turístico possuidor de praias urbanas despoluídas e áreas verdes urbanas ainda preservadas. Um espaço que detém um caráter especial e raro com relação a algumas áreas próximas, que parece estar no aguardo de uma (possível) maior valorização futura. Um espaço em "pousio" como diria Moraes (2007, p. 212), uma reserva territorial mantida sob forma de especulação. Nesta dinâmica, o capital não perde por esperar.

O consumo de massa é incorporado à atividade de turismo que passa a conceber o espaço como mais uma mercadoria a ser consumida de forma rápida e passageira. Diante desse modelo de turismo, que privilegia o consumo de massa, a cidade de João Pessoa passou a sofrer transformações e interferências que mudaram a concepção de seu espaço. Este novo espaço mercadoria (idealizado) projeta-se agora repercutindo de forma concreta na cidade, dando-lhe novos aspectos na sua aparência com a finalidade de desenvolver e divulgar a imagem positiva do lugar.

Segundo Becker (2002, p. 184) “os territórios são valorizados em função da sua acessibilidade, às vezes em função do marketing, que vende a sua imagem, e em função da natureza também que se for bem vendida, digamos assim, é valorizada". Portanto, a produção de uma imagem urbana favorável ao consumo é prerrogativa de um sistema de produção de imagens ideológicas que tem no marketing seu principal realizador. As estratégias de marketing surgem como meios efetivos de proporcionar a formação de 
idéias favoráveis sobre lugares a serem vendidos como produtos turísticos, sendo capazes de atrair grande quantidade de consumidores (BECKER, 2002).

A partir dos projetos de desenvolvimento do turismo ocorre um acelerado aumento da propaganda voltada para o turismo, com uma expansão das mídias impressa, televisiva e na internet. Neste momento sair do lugar comum era, na verdade, movimentar-se por um espaço desconhecido, cidades desconhecidas nunca antes visitadas por turistas. O litoral paraibano, dentro desta política de turismo, entra na promoção como um importante produto turístico da região, vendido pelo exotismo das praias, belezas naturais e possibilidade de verão o ano inteiro.

O marketing e a propaganda são elementos importantes para a viabilização dos projetos de atuação sobre os espaços destinados ao turismo. Não basta só fazer os investimentos no espaço para a sua valorização, é preciso que ele seja valorado para que o retorno do capital investido esteja de certa forma garantido. Esta nova modalidade de marketing está diretamente relacionada ao processo da transformação do espaço em mercadoria, pois, dentro das relações capitalistas só se faz propaganda daquilo que se pretende "vender". Informar sobre este espaço redefinido sob esta nova ótica, e ainda desconhecido dos potenciais consumidores é extremamente necessário, no sentido de pôr em prática o seu processo de valoração. Afinal, só se valora aquilo que se "conhece".

No contexto do turismo nordestino os materiais publicitários exercem um importante papel de divulgadores de "maravilhas tropicais". Os mapas se inserem neste contexto como instrumentos eficazes na comunicação sobre o espaço turístico. Carregados de valores, os mapas também podem, assim como os materiais publicitários (folders, cartazes, revistas), promover um espaço idealizado, trabalhando para legitimar os discursos ditos sobre os lugares. Deste modo, nosso questionamento se estabelece no sentido de descobrir como a imagem da cidade de João Pessoa está refletida nos mapas turísticos. Quais os discursos e os valores sobre a cidade que estão sendo comunicados através desses mapas?

Mas, é necessário esclarecer que não consideramos os mapas turísticos apenas como materiais publicitários. Entendemos que, eles não somente informam sobre o espaço, eles são o espaço, que está sob a forma de um mapa que o turista pode levar consigo para onde for. Eles comunicam não apenas as informações relativas ao espaço como os materiais publicitários fazem. Os mapas turísticos comunicam o espaço. 
Os mapas em questão são mapas temáticos cujo tema é centrado na localização dos lugares de interesse do turista. Seu objetivo principal é apresentar a cidade de forma clara, facilitando a localização e o deslocamento dos turistas/visitantes por meio dos melhores caminhos ou rotas. Através deles os turistas viajam mais de uma vez pelo mesmo espaço, quando planejam e traçam os roteiros, e retornam aos mapas para confirmá-los. De posse de um mapa turístico as pessoas podem se deslocar pelo espaço turístico da cidade, adquirindo uma noção de localização e direção que as fazem se apropriar mais do conhecimento da geografia do lugar. Dessa forma, buscamos a compreensão da contribuição desses mapas na construção do ideário turístico da cidade de João Pessoa. 


\section{Capítulo 3}

\section{A cidade dos mapas turísticos: \\ linguagem, comunicação cartográfica, discurso e poder}

Desde há muito tempo o homem sente a necessidade de representar o mundo em que vive. Várias são as descobertas arqueológicas de inscrições rupestres que demonstram este fato. As primeiras inscrições se caracterizam por serem imagens, que na maioria das vezes são representações de cenas do cotidiano, com figuras do corpo humano, animais, o céu, o sol e as estrelas. Para Valente e Brosso (1999) o Homo sapiens utilizou primeiro a imagem, através de objeto-símbolo, para comunicar e guardar suas memórias, só depois foi criada a escrita. Neste processo de desenvolvimento da comunicação foi que a humanidade, para se comunicar, passou a atribuir conceitos às coisas, generalizando os fenômenos e representando-os através de símbolos e signos.

Diante da complexidade do mundo o homem se vê ante a necessidade de estabelecer estratégias para compreender e explicar a realidade, representando, simplificando e reduzindo-a à modelos de síntese. A realidade passa a ser codificada, modelada através de signos e símbolos de acordo com a necessidade de se compreender e se explicar o mundo em toda sua complexidade.

De acordo com Oliari (2004) na comunicação acontece uma interação entre o homem e os sinais ocorrendo transformações em sentido duplo, ou seja, a mensagem e o homem são transformados simultaneamente. Assim, a comunicação passa a acontecer através de métodos e processos tais como a linguagem. Esta, portanto, pode ser considerada como qualquer sistema de signos que sirva de meio de comunicação de informações entre indivíduos, podendo ser percebida pelos diversos órgãos dos sentidos, o que leva a distinguirem-se vários tipos de linguagens, visual, auditiva, tátil, etc., ou ainda, outras mais complexas, constituídas, ao mesmo tempo, de elementos diversos (HOLANDA, 1988). 
Toda linguagem humana é social, na medida em que apenas um ser social é capaz de dialogar. Não é fixa, nem absoluta, guarda traços de subjetividade - resultado de processos históricos e construções sociais - e está em constante processo de mudança. Sendo uma construção social a linguagem é formada num contexto de múltiplas relações, processo este fortemente permeado pelo poder. Neste sentido, Foucault (1967) nega a individualidade do homem quando diz que a produção de um discurso é um ato social. Sendo de natureza social o discurso se institui a partir de um jogo de forças, onde os mais fortes adquirem o direito sobre ele, fixando-se como uma imposição, um ato de violência, de força. Quem adquire os meios de proferir a verdade estabelece relações desiguais sobre aqueles que não os têm. Por isso existe uma luta pelo seu domínio, pois quem tem o direito sobre o discurso, tem o poder.

Quando se fala em poder associado à linguagem remete-se invariavelmente ao termo ideologia que, para Barthes (2003), é " [...] linguagem e nada mais que linguagem: é um discurso, um tipo de discurso". O discurso se torna ideológico a partir do momento em que não se diz tudo, quando há o implícito, quando a subjetividade é possível. Para Foucault

certamente os discursos são feitos de signos; mas o que fazem é mais que utilizar esses signos para designar coisas. É esse mais que os torna irredutível à língua e ao ato de fala. É esse "mais" que é preciso fazer aparecer e que é preciso descrever (FOUCAULT, 2005, p. 55).

A cartografia se expressa através de mapas representando os aspectos do mundo a partir da composição de signos convencionais organizados de forma que se obtenha uma imagem aproximada da realidade. Os mapas são objetos que se transformam numa versão reduzida da realidade, tornando possível transportá-la.

Um mapa pode levar os lugares a qualquer lugar. Foi o que aconteceu quando foram trazidos nos navios dos colonizadores os mapas e as plantas que foram modelos a partir dos quais se construíram cidades e vilas nos moldes dos traçados das portuguesas. Segundo Latour (2000, p. 363), a cartografia é um dos meios mais extraordinários de possibilitar uma atuação à distância "sobre eventos, lugares e pessoas". Ele explica que ela possibilita que a realidade se torne móvel (para ser transportada), se mantenha estável (para ser preservada) e que seja combinável de forma que os aspectos dessa realidade "possam ser acumulados, agregados ou embaralhados como um maço de cartas". 
Contudo, como em qualquer tipo de linguagem, através dos mapas também é possível expressar discursos que são permeados de ideologias e que se tornam fundamentais nas relações de poder, especialmente naquelas relacionada à apropriação do espaço.

Os mapas, elementos de comunicação do espaço, há muito tempo têm sido utilizados como instrumentos de apoio ao poder. Portanto, eles são uma junção de informações sobre um determinado espaço. Elaborados e constituídos socialmente, tem como uma de suas finalidades principais, comunicar informações sobre o espaço, expressando fortemente as vontades dos poderes políticos. Por sua vez, Lacoste (1993), já afirmava ser imprescindível saber pensar o espaço e analisá-lo de acordo com uma escala apropriada para poder nele agir da forma mais eficaz possível, tornando-se o conhecimento do espaço uma ferramenta poderosa para o seu domínio.

Cortesão (2009) também aponta os mapas como ferramentas de apoio ao sistema do poder político afirmando que são expressões das vontades políticas dos governantes, refletindo principalmente os propósitos daqueles que mandam. Para Cortesão (2009) há sempre uma busca do significado histórico e político do mapa, sendo eles documentos e imagens vivas do passado.

Esta concepção de cartografia está fundamentada numa visão crítica que considera a presença de uma ligação entre o conhecimento geográfico e o poder. Baseada no processo de renovação teórico metodológico por que passa a cartografia em meados dos anos 1980, essa concepção considera a cartografia uma expressão política, negando sua neutralidade científica. Ao traçar um panorama das contribuições metodológicas e epistemológicas da história da cartografia Gomes (2004), afirma que, entre as décadas de 1980 e 1990, pode ser claramente observado um processo de renovação, ou mais propriamente, um alargamento dos horizontes teóricos e metodológicos da história da cartografia.

Com este movimento a cartografia tornou-se indisciplinada, com tendências de liberdade das fronteiras rígidas do academicismo, se colocando como uma possibilidade de uso para as pessoas comuns (CRAMPTON e KRYGIER, 2006).

É sobre esta influência que este estudo, que tem como enfoque os mapas turísticos de João Pessoa, se baseia e terá como principal direcionamento teórico J. Brian Harley 
como um dos pioneiros do desenvolvimento de uma cartografia crítica, para fundamentar nossos esforços de compreensão sobre os mapas como textos históricos e seus discursos.

O seu corpo teórico se origina a partir da ruptura com a cartografia tradicional, de visão positivista e fundada sobre o mito da ciência objetiva e neutra. Em seus estudos fomentou o processo de renovação da cartografia questionando o conceito e a afirmação de objetividade dos mapas, convocando os teóricos para uma ampliação dos horizontes epistemológicos da disciplina, pregando que a cartografia deveria considerar também os elementos não positivistas em suas práticas. Este autor inaugura uma história da cartografia que passa a enxergar as realidades políticas e culturais embutidas nas informações dos mapas. Para ele, mais do que coordenadas geográficas e informações técnicas, os mapas descrevem muitos aspectos contraditórios da sociedade da época em que foi elaborado. Sua ideia era a de que os mapas seriam um tipo de linguagem gráfica que agrupava, entre suas informações técnicas, um conteúdo ideológico muito significativo, capaz de comunicar muito mais além do aparentemente posto. Com isso ele considerava que

los mapas son una parte de la familia más amplia de imágenes cargadas de valor. De este modo, he renunciado a entender los mapas como registros inertes de paisajes morfológicos o como reflexiones pasivas del mundo de los objetos; más bien los considero imágenes reflejadas que contribuyen a un diálogo en un mundo construido socialmente (HARLEY, 2005, p. 80).

Para Harley (2005) o mapa é uma construção social do mundo na medida em que é feito por profissionais formados no seio de uma sociedade e, portanto, influenciados por uma produção técnica e por uma produção cultural. Chamava atenção para o fato de que os mapas deveriam ser vistos mais como uma representação do poder do que apenas como uma representação de aspectos topográficos da paisagem. $\mathrm{O}$ mapa se torna instrumento de conhecimento e domínio do espaço, na medida em que o conhecimento é poder, pois viabiliza estratégias mais eficientes para apropriação e domínio, tanto físico como ideológico, do espaço. Um mapa é um tipo de linguagem cartográfica impregnada de ideologias, um tipo de imagem retórica que, como os livros, se tornaram uma força política na sociedade (HARLEY, 2005, p. 81).

A sua leitura deve ultrapassar o sentido literal, buscar o subjetivo dentro do discurso oculto, procurar ver para além do que está posto no mapa. Buscar enxergar 
aquele detalhe a mais que Foucault aponta como “esse 'mais' que é preciso fazer aparecer e que é preciso descrever" (FOUCAULT, 2005, p. 55). Harley afirma que, dentro de um mapa pode haver vários textos, uma intertextualidade que teria que ser descoberta no processo de interpretação. Suas concepções foram muito influenciadas pelos argumentos de Michel Foucault sobre o poder e sua relação com o conhecimento. Nesta compreensão, Crampton e Krygier (2006) destacam a sensibilidade de Foucault para aspectos geográficos e espaciais, na medida em que aquele autor considera que muitos problemas de natureza política requerem conhecimento espacial.

Desde o século XVII os cientistas têm produzido e divulgado um modelo científico de cartografia em que o mapeamento adquire o caráter de modelo correto; a expressão verdadeira da realidade reconstruída através da matemática. A tendência de concebê-los os mapas de acordo com regras que reafirmam apenas suas características técnicas tem levado muitos mapas do passado a serem desconsiderados como fontes documentais importantes (HARLEY, 1991). Assim como muitos mapas de culturas não ocidentais que não utilizavam as mesmas técnicas europeias de mapeamento, durante muito tempo, foram considerados apenas meras curiosidades etnográficas.

Los mapas de culturas no europeas únicamente recibían cierta atención por parte de los historiadores occidentales cuando presentaban alguna semejanza con los mapas europeos. [...] Así, los mapas trazados en la India antes de la ocupación británica, con sus signos desconocidos y su estilo pictórico, no sólo figuran recientemente en las descripciones convencionales de la historia de la cartografía. No se los reconocía como mapas o bien eran desechados como curiosidades peregrinas, dignas únicamente de engrosar las colecciones de objetos etnográficos diversos (HARLEY, 1991, p. 11).

$\mathrm{O}$ autor considera os mapas textos que devem ser lidos levando-se em conta o contexto da época em que foram feitos. São documentos históricos passíveis de serem lidos e interpretados através de uma visão crítica apoiada no método histórico. Portanto, os mapas não são apenas imagens que podem ser verdadeiras ou falsas, são textos escritos sobre um mundo social, composto a partir de relações de poder que geram forças desiguais, entre práticas e prioridades culturais diversas.

Mark Monmonier (1991) fez uma ampla abordagem teórica sobre a questão dos cuidados com a precisão cartográfica, considerando também os mapas como símbolos de poder estratégico e tomados por forte conteúdo ideológico. O autor concentra seus estudos 
de cartografia histórica no século XX, época em que há um grande avanço nas tecnologias de mapeamento e, com isso, maior possibilidade de ampliação do público de mapeadores. A sua concepção de cartografia está muito atrelada aos princípios notadamente científicos, com base na busca de um rigor técnico dos mapas. Um de seus enfoques, transformado em livro, trata especificamente sobre os erros e mentiras contidos nos mapas. Para Monmonier (1991), a rapidez no crescimento do uso de computadores e a democratização do acesso às publicações de materiais cartográficos, como imagens e mapas, tornou mais complexa a questão dos erros e mentiras cartográficas, pois o usuário poderá se enganar ou ser enganado sem nem mesmo perceber. Para este autor, atualmente com o avanço técnico qualquer um pode se tornar um "produtor de mapas", mesmo sem a capacitação técnica para tal. No setor do turismo estas facilidades técnicas relacionadas à cartografia, como também as relacionadas às técnicas gráficas, viabilizaram ainda mais a elaboração de mapas turísticos pelo marketing turístico. Para Momonmier (1991) esta realidade da expansão e democratização do fazer cartográfico via meio eletrônico torna ainda mais problemática a questão dos erros nos mapas.

Esta concepção de cartografia tende a considerar como mapa apenas aqueles que estiverem estritamente dentro das especificações técnicas da cartografia acadêmica. Com isto, termina sendo negado às pessoas comuns o seu conhecimento geográfico prévio adquirido com a vivência cotidiana com o seu espaço. Conhecimento que, por exemplo, faz as pessoas saberem o melhor trajeto para se chegar a um determinado lugar. Nega-se assim, das pessoas, um conhecimento básico para elaborar um roteiro através de mapas mentais. Nega-se delas o direito de solucionar questões geográficas simples como, por onde ir, como chegar, ou qual o melhor caminho para se chegar à um lugar. Saber traçar linhas e caminhos a partir de pontos de referências espaciais próprios, deve ser direito de todos, que mesmo sem possuir capacitação técnica ou científica, detém o seu próprio saber geográfico, a sua própria geografia. Para Harley

Los mapas dificultaron de manera invisible la vida cotidiana de la gente común. Así como un reloj, como símbolo gráfico de la autoridad política centralizada, trajo consigo la "disciplina del tiempo" al ritmo de los trabajadores industriales, las líneas de los mapas, dictadoras de una nueva topografia agraria, introdujeron una dimensión de "disciplina del espacio" (HARLEY, 2005, p. 90-91). 
Neste sentido, a consequência da popularização das técnicas de cartografar o espaço e a ampliação das possibilidades de fontes abertas de mapeamento como os mapas interativos foi que a exclusividade do mapeamento não está mais nas mãos dos técnicos e cartógrafos. A tecnologia facilitou o procedimento até que qualquer usuário atualmente seja capaz de mapear, tenha a liberdade de fazer seus próprios caminhos e representar seu espaço. Os mapas são dinâmicos e interagem com as pessoas de uma forma significativa atuando muito fortemente no processo de construção do conhecimento sobre a realidade, tornando-se um poderoso meio capaz de promover mudanças sociais. Tem-se, portanto, duas vertentes: de um lado, o domínio aparentemente neutro do mapeamento científico atrelado ao poder do estado versus as distorções e possíveis erros contidos nos mapas dos mapeadores amadores.

Neste trabalho escolhemos não trabalhar com a questão da dicotomia certo-errado por optar em considerar uma concepção mais ampla do que venha a ser um mapa. De acordo com Harley (2005), consideramos que os mapas são perspectivas do mundo no momento em que foram feitos.

Quanto à questão da omissão na cartografia compreende-se que muita coisa referente ao mundo que vivemos não é cartografada, da mesma forma como muitos temas têm sido deixados de lado pelas companhias editoriais e pela mídia em geral. No entanto, para a cartografia histórica é possível, através de seu método de leitura do mundo, fazer uma leitura através dos mapas ou para além dos mapas. Para isso, deve-se realizar uma análise utilizando todos os elementos indicativos possíveis e relacionando-os uns com os outros. Podemos citar alguns elementos materiais, ou internos aos mapas, como tipo de papel, tamanho, as cores, o tipo de publicação (se é encarte de publicação de textos escritos, se é encarte publicitário ou mapa avulso). Podem ser considerados também, neste grupo de elementos, os simbólicos, onde entram os detalhes decorativos, os tipos de letras, seus tamanhos e cores, os cabeçalhos, as dedicatórias e os adornos.

No método de análise histórica de mapas a decoração cartográfica não é considerada apenas um exercício estético e secundário, mas um reforço ideológico forte e eficiente. Os elementos externos aos mapas também devem ser levados em consideração, como o contexto histórico do mapa, o contexto do cartógrafo (social, político, profissional), como também o mapa analisado deve ser relacionado ao contexto de outros mapas. 
Os mapas turísticos, objetos desta análise, estão longe de serem considerados pelos cartógrafos como modelos científicos e objetivos de representação do espaço. Os cartógrafos tendem a diferenciar os mapas imparciais ou objetivos dos mapas usados com finalidade de propaganda ou publicidade (HARLEY, 2005). Os mapas turísticos são mapas temáticos, direcionados a um público específico e apresentam a característica de serem especialmente retóricos. Eles fazem parte de um discurso de convencimento acerca de uma idéia central, possuindo uma credibilidade capaz de tornar verdade uma retórica. Neste sentido, não são neutros e possuem um conteúdo ideológico muito forte, estando muito frequentemente a serviço dos grupos que detém o poder econômico. Portanto, estes mapas fazem parte de um complicado jogo em que o espaço se torna moeda de alto valor.

O mapa pode ser pensado como uma imagem carregada de valores, na medida em que apresenta uma série de informações através da combinação de símbolos e signos, que juntos sintetizam informações sobre um determinado lugar. Um mapa, de início, apresenta um objetivo declarado de acordo com aquilo que propõe representar, mas além dessas mensagens previstas acaba por expressar muito mais do que o proposto. A leitura de um mapa deve ser feita a partir de uma visão crítica, de forma ampla e transparente, procurando a compreensão da realidade posta através de vários ângulos e levando em conta a multiplicidade de visões existentes. Numa interpretação histórica é necessário levar em conta três aspectos que influem na leitura dos mapas como textos: o contexto do cartógrafo, o contexto de outros mapas e o contexto da sociedade. Consideramos que estes três aspectos guardam uma relação intrínseca entre si, tornando parte da mesma realidade social repleta de subjetividades e contradições, as quais a cartografia tradicional não alcança (HARLEY, 2005). 


\section{1 - A análise dos mapas: o desvendar dos discursos sobre o espaço turístico da cidade}

É comum encontrar pela cidade, principalmente em pontos de atração turística, muitos materiais publicitários com enfoque na temática. Os mapas, dentre eles, são muito procurados. Possuidor de uma linguagem visual bastante agradável e acessível, esses mapas muitas vezes lembram livros de histórias infantis que remetem as pessoas a identificar o espaço cartografado como um espaço lúdico. Esta identificação é muito oportuna a partir do momento em que a atividade do turismo tem o lazer, a diversão e o prazer como alguns de seus pré requisitos fundamentais. Os mapas são textos culturais e, a partir do momento que aceitamos a sua textualidade, lançamos mão de diversas possibilidades interpretativas. É possível com isso que, ao invés de percebermos apenas a sua transparência, possamos perceber também as suas opacidades e, ao invés de percebermos apenas a sua aparente inocência, possamos despertar para as suas dualidades (HARLEY, 2005).

Dentro da mídia impressa os mapas são importantes canais de veiculação do produto turístico indicando os hot points e sendo instrumento de orientação dos roteiros dos turistas. Juntamente com outros tipos de materiais publicitários, como cartazes, revistas, folders, etc., os mapas promovem o espaço turístico construindo um discurso permanente sobre ele que termina por cristalizar uma imagem positiva que muito interessa ao mercado.

Para este trabalho optamos em fazer uma leitura dos mapas turísticos que foram distribuídos na cidade, buscando identificar qual é a imagem síntese que aparece impressa nesses mapas. Com esta análise buscamos identificar o que está expresso numa série de mapas investigados, levando em consideração também o contexto das transformações ocorridas no espaço da cidade.

O desafio colocado nesta proposta de trabalho é como ser capaz de ler, através dos mapas turísticos, a imagem da cidade à luz da cartografia histórica, levando em conta $\mathrm{o}$ processo de formação da cidade e seu desenvolvimento dentro do contexto do capitalismo, procurando evidenciar as desigualdades geradas neste processo e refletidas ou ocultadas nos mapas. 
A perspectiva deste estudo foi fundamentada na cartografia histórica, que orientou a investigação dos mapas como elementos de comunicação de informações sobre o espaço geográfico. Esta concepção de cartografia se baseia na crença de que há ligação entre o mapa e o poder especialmente o político e o econômico, relação esta que reflete nos discursos e interfere diretamente na produção social do espaço. Sob este enfoque os mapas são elementos capazes de transmitir discursos e ideologias acerca do mundo cujos propósitos estão centrados na consolidação dos objetivos dos que detém o poder, inclusive o de comunicar. Consideramos que os mapas turísticos refletem um discurso acerca do espaço da cidade que se fundamenta numa ideia central, adquirindo uma credibilidade capaz de tornar verdade uma retórica. $\mathrm{Na}$ leitura proposta serão levados em conta aspectos contraditórios e relações de forças opostas que, na maioria das vezes, não aparecem de forma clara na composição dos mapas, mas de forma disfarçada e subliminar.

Para analisar os discursos contidos nos mapas turísticos da cidade a proposta se coloca no sentido de desconstruir estes discursos identificando com isso os elementos relacionados à segregação espacial que estão diretamente vinculados à apropriação financeira do espaço turístico. Nesta desconstrução é necessária uma leitura mais detalhada e aprofundada do mapa para perceber pistas importantes para elucidação dos fatos pertencentes ao espaço cartografado. Deve-se ir além de uma leitura literal do mapa, de uma localização de lugares, considerando-os menos como uma sequência de processos técnicos e mais como um texto cultural capaz de dizer muito sobre o jogo de forças sociais que constroem e reconstroem a realidade representada.

João Pessoa se apresenta dentro do cenário turístico nacional como uma cidade possuidora de duas vocações distintas, mas muito importantes para o turismo nordestino. Por sua localização a cidade possui uma orla marítima que é um aspecto fundamental para o turismo de "sol e mar" e um Centro Histórico que contempla características necessárias para o tipo de turismo cultural que ressalta o patrimônio como interesse turístico. Essas duas áreas se configuram dentro da atividade como um locus privilegiado para as ações do Estado como principal provedor de benefícios de infra-estrutura.

Os mapas analisados foram consultados na biblioteca da PBTUR, em João Pessoa, onde existe, além de um acervo de mapas turísticos da cidade, um conjunto de material publicitário voltado ao turismo. Selecionamos para a análise 67 mapas turísticos da 
Região Metropolitana de João Pessoa desde o ano de 1979 até os dias atuais. Este recorte temporal foi o estabelecido de acordo com o material disponível, levando em conta que o acervo não se apresentava de forma organizada e preservada, contendo poucos exemplares das décadas de 1980 e 1990.

Foi realizada uma análise detalhada em cada mapa, detendo-se em seus aspectos internos (como tipo de papel, tamanho, cores, letra, etc.) e em seus aspectos externos (relacionados ao contexto histórico e social). Através da análise destes aspectos foi possível identificar o que estes mapas, em seu conjunto, expressam sobre a história do espaço turístico da cidade de João Pessoa. Todos os detalhes aparentes foram levados em conta nas análises que buscaram a desconstrução de cada mapa. Cada detalhe revelado serviu de elemento fundamental para a identificação dos discursos e ideologias que se escondem por detrás das imagens dos mapas turísticos, em cuja retórica pode se desvendar traços da história territorial de João Pessoa.

As questões fundamentais que aqui se colocam e que nos interessam descobrir são: como os mapas turísticos da cidade de João Pessoa expressam o processo de transformação de seu espaço e das apropriações deste espaço? De que forma eles colaboram no discurso da necessidade de um espaço cada vez mais voltado aos prérequisitos das atividades turísticas? Procuramos enfim, identificar quais as histórias sobre o espaço da cidade que são contadas, ou ocultadas, através das imagens destes mapas

\section{2 - João Pessoa: um produto turístico no mercado de cidades}

No turismo o produto principal a ser vendido é o espaço que recebe as interferências necessárias para que se transforme numa imagem que seja ao mesmo tempo mítica, sedutora e persuasiva. Uma imagem que ative diretamente o campo psíquico, influenciando o sentimento e o desejo das pessoas. Todo este processo é socialmente construído a partir de ações e representações geradas coletivamente, onde as ideias e as motivações são transmitidas e reforçadas através das práticas e dos discursos.

Neste processo de compra e venda é comum perceber que o espaço das cidades tem sido apresentado de formas muito semelhantes, apesar de possuírem, cada um, características culturais, políticas e urbanísticas próprias. Isso é reflexo de uma organização capitalista do consumo que submete e fragmenta o espaço transformando-o 
em uma coleção de mercadorias, dispostas a uma contemplação e a um consumo quase inevitável. A ideologia fortemente se instala através da composição de uma imagem que tem o poder de sintetizar todas as melhores características possíveis de serem incorporadas a este espaço, tornando-o alvo de desejo. Sobre esta "uniformização do cenário" do espaço, Lefebvre (1999, p. 31) afirma tratar-se de "uma aparência caricata de apropriação e de reapropriação do espaço [...]", onde esta uniformização reserva aos objetos (mercadorias) os efeitos de cores e formas que os tornam atraentes, não necessariamente pelo que são, mas por aquilo que representam.

As cidades, dentro de um panorama de competição, tentam se superar e acabam tornando-se o espelho umas das outras. Temos, então, projetos de cidades que são apresentados através de imagens tão semelhantes entre si, que nos levam a pensar "por que se vendem cidades e o que efetivamente se vende ao vendê-las" (SANCHEZ, 2010, p. 15). Isto se dá no contexto atual, que surge depois da crise mundial que gerou um novo modelo para as cidades (Harvey, 2005), demandando com isso, uma corrida para adequação de seus espaços que, cada vez mais abstratos, se transformam em mercadorias.

Para se adequar a esta nova realidade a cidade adquire a personalidade que lhe é atribuída pelos agentes públicos, promotores do espaço e pela sociedade e, neste movimento, vai se apagando aos poucos a sua imagem social original. Sobre esta dinâmica de construção, reconstrução e mediação do espaço, Lefebvre (1969) afirma ser a cidade como uma obra de arte, produzida e reproduzida através de relações sociais; assim, mais do que uma produção de um objeto, ela é o resultado de um processo de construção histórica de uma sociedade. É dessa integração entre agentes históricos e sociais e sua obra, e de uma impossibilidade de separação entre eles, que surge a realidade urbana como uma obra social, construída a partir de mediações entre processos econômicos, sociais, políticos, culturais.

Nesse movimento, o status do espaço se transforma de um valor ligado à sua imagem social original, para outro, que é vendido através de sua imagem artificialmente elaborada. No entanto, esta síntese abstrata do espaço, na verdade, muito pouco diz sobre a sua essência social. O importante no mundo da produção em massa e da uniformização de tudo é vender em grosso, tudo aquilo o que for possível de ser transformado em valor de troca. 
Nesse contexto, as propagandas têm o papel fundamental de interferir nos aspectos cognitivos, afetivos e comportamentais das pessoas, fazendo com que o espaçomercadoria seja produzido a partir de um modelo pré-idealizado, primeiramente pelos agentes do marketing e, posteriormente, adquirindo as características que os novos consumidores desejam. É essa mediação, entre o que se tem e o que se quer, que faz a realidade social uma prática cotidiana que se repete e se renova num movimento constante. Assim, para o turismo, as estratégias de marketing para a viabilização do espaço-mercadoria se tornam a espinha dorsal da atividade, na medida em que, tem a capacidade de mudar a percepção das pessoas sobre os lugares.

Considerando especialmente os mapas turísticos, é de interesse para este trabalho perceber como a imagem da cidade de João pessoa tem sido apresentada. De que forma esta imagem síntese está sendo construída e veiculada através desses mapas? Que tipos de discursos sobre a cidade são transmitidos por eles para que o seu espaço seja transformado num valor de troca cada vez mais viável para o capital?

Ao se observar qualquer cidade sob o ponto de vista do turismo é possível perceber a presença de uma estratégia de marketing pensada por trás das ações de publicidade. $\mathrm{O}$ marketing relacionado ao turismo é o responsável pela criação da ideia que se quer transmitir sobre um produto que, quando definida e difundida, se transforma automaticamente em uma imagem mental. O processo de criação dessa imagem se dá com foco centrado em dois aspectos: a intenção e o público alvo. A construção desta ideia ou imagem-síntese faz parte da dinâmica dos processos políticos, econômicos e culturais que ocorrem na estruturação e na produção do espaço do turismo atual. O marketing neste processo pode ser capaz de criar, além de novos produtos, novas necessidades.

A publicidade e a promoção turística da cidade de João Pessoa antes da década de 1970 já existiam, apesar de pouca difusão fora do Estado. De acordo com Leal (2001), algumas publicações ${ }^{15}$ de caráter turístico foram editadas até o final da década de 1970

\footnotetext{
${ }^{15}$ Guia da Cidade de João Pessoa (Autoria de Celso Mariz, 1939); Guia da Paraíba (Autoria de Ademar Vidal, 1943); Guia Informático de João Pessoa (Autoria de José Leal, 1967); Jornal A União (várias matérias sobre a temática na Coluna "Relações Públicas e Turismo", 1960); Primeiro Guia Turístico (Editado pela PROPAN, 1968); Revista Edição Extra (Década de 1970); Guia Tourinho (Autoria de H. Tourinho, Sd); Guia dos Monumentos Históricos de João Pessoa (Autoria de Evandro Nóbrega); Revista
} 
por diversos autores, antes de serem centralizadas pela PBTUR. A partir da década de 1980, já com o direcionamento da Embratur no que dizia respeito à propaganda para o turismo, a PBTUR foi responsável pela maioria das publicações acerca do tema. Diversas publicações sobre a temática foram lançadas, entre folhetos, folders, mapas e revistas, num esforço de fomentar as atrações da cidade e do Estado no entanto, a grande maioria teve vida curta, como é o caso da revista Alternativa que circulou apenas com três edições.

No conjunto dessas publicações é possível perceber o desenvolvimento de uma imagem renovada da cidade que, aos poucos, vai apagando qualquer vestígio da sua imagem original (aquela desenvolvida a partir dos processos sociais locais). Através de seus textos e fotografias podemos perceber uma construção efetiva de discursos acerca de seu espaço, cuja finalidade se concretiza na sua transformação em valor de troca, inserindo a cidade de João Pessoa no circuito turístico do capital. Vários desses discursos apontam para uma obediência aos direcionamentos das políticas de turismo para o país que inseriu as cidades litorâneas do Nordeste no modelo de turismo de sol e mar.

Ao analisar a propaganda turística veiculada sobre João Pessoa, Leandro (2006, p. 164) identificou vários discursos repassados através de slogans e frases que reforçam aspectos positivos da cidade turística: "João Pessoa, cidade verde”, “João Pessoa, ponto extremo oriental das Américas", João Pessoa, cidade de se viver" e "João Pessoa, uma cidade de quatro séculos". Sobre a presença de $\operatorname{slogans}^{16}$ destacando as qualidades, ora

Paraíba Turística e o Novo Guia de Turismo (Editados especialmente para a festa de inauguração do Tropical Hotel Tambaú, 1971).

${ }^{16} \mathrm{O}$ autor identifica mais de cinqüenta slogans: "Pequenina e heróica"; "Paraíba mulher macho"; "Pode vir que tem hotel"; "Paraíba, Sempre verão"; "Descubra a Paraíba"; "Terra gotosa, sim senhor"; "A Paraíba espera por você"; "Paraíba, o melhor do Nordeste"; "Viva a Paraíba"; "Paraíba quatrocentona”; "Paraíba 4 séculos de história"; "Descubra este paraíso"; "Paraíba, sim senhor"; "Paraíba, seu novo amor"; "A Paraíba está no ponto"; "O ponto extremo mais oriental das Américas"; "Onde o sol chega primeiro"; "Onde o sol nasce primeiro"; "O primeiro sol das Américas"; "Paraíba - Turismo o ano inteiro"; "É tempo de vir"; "Alto astral"; "Sol e mar pra você"; "Um pedacinho do Brasil repleto de emoções"; "O recanto mais bonito do Brasil"; "Sol o ano inteiro"; "12 meses de sol"; "Venha ser nosso hóspede"; "Esse é um bom lugar"; "Temperatura máxima"; "A Paraíba se liga"; "Pecado é não provar"; "O centro do Nordeste”; "Sol e mar"; "A tranqüilidade existe"; "Viva João Pessoa"; "A capital das acácias"; "Cidade de se morar e visitar"; "É toda sua"; "Capital do sol e do verde"; "Viva essa emoção"; "Descubra João Pessoa"; "João Pessoa quer conhecer você"; "A segunda cidade mais arborizada do mundo"; "Inclua no seu roteiro esse cenário de emoções"; "Nossa indústria produz sonhos"; "Uma cidade verde a sua espera"; "De bem com a natureza"; "Já nascemos cidade"; "Paraíso Barroco"; "Cidade de rio, sal e mar". "Terceira cidade mais antiga do Brasil"; "Capital natural". 
do Estado, ora de sua capital, Leal (2001) destaca que os mesmos podem ser identificados desde a década de 1930 em meio a discursos de políticos, notícias de jornais, versos de poetas e letras de músicas. Percebem-se, nesse momento, os agentes públicos, os promotores do espaço e a sociedade, eis a dinâmica e o processo de construção, reconstrução e mediação. Assim começa a surgir a cidade idealizada, que posteriormente resultará na mercadoria que hoje ocupa lugar no competitivo mercado das cidades.

Nesse processo de transformação do espaço em mercadoria, que tem um de seus principais mediadores a atividade turística, a mídia se insere como excelente facilitador da divulgação das imagens tendo um papel importante na promoção desse espaço. No contexto atual a internet vem ampliar sobremaneira esse espaço de negociação por meios dos novos canais virtuais de promoção, venda, troca e divulgação dos espaços como produtos.

Apesar deste amplo alcance e das facilidades que a mídia virtual apresenta ainda se verifica muita propaganda e publicidade sobre destinos turísticos veiculadas nas mídias tradicionais impressas, como revistas, catálogos, encartes, folhetos e guias turísticos. Neste raciocínio, podemos dizer que, da mesma forma que a mídia impressa ainda se apresenta como importante recurso do processo de produção e promoção do turismo, os slogans também se mantêm como uma estratégia muito utilizada que, juntamente com as imagens e fotografias dos lugares, ajudam a compor a imagem-síntese de uma cidade.

Essa composição de uma imagem-síntese promovida por um conjunto de estratégias, que tem no marketing o principal agente direcionador, parece ter, por finalidade, fazer saltar aos olhos aquilo que o visitante deve apreender sobre a cidade. É um exercício poderoso de convencimento que impõe o que deve ser lembrado acerca daquele espaço. Pois, o que deve ser lembrado normalmente é apresentado, não apenas enquanto peculiaridades do lugar, mas como atributos inegociáveis através dos quais a cidade escolhida é efemeramente apropriada.

Os slogans, assim como as outras estratégias de marketing, trazem ao primeiro plano da percepção uma cidade que certamente não é aquela possuidora de um cotidiano marcado pelos problemas comuns a outras como, a insuficiência de infra-estrutura, desigualdades sociais, problemas de trânsito, violência e inúmeros outros que são recorrentes. Não se trata apenas de uma promoção das possíveis qualidades pertencentes ao lugar, as frases de efeito podem atuar de forma caricata e exagerada, enaltecendo uma 
suposta peculiaridade de um destino turístico, fazendo com que este lugar se destaque por atributos forçadamente construídos ou exageradamente exaltados.

Dentro desta perspectiva, ao analisar os mapas turísticos de João Pessoa identificamos vários discursos acerca do espaço da cidade que se repetem em muitos momentos. Elegemos três discursos dentre eles, por considerá-los os mais importantes e significativos, principalmente por sua recorrência nos mapas. O primeiro é um discurso geográfico, que se caracteriza por evidenciar atributos de localização geográfica da cidade, como por exemplo, a proximidade do mar. Outro identificado é o discurso da natureza que está relacionado aos aspectos naturais/ambientais do espaço da cidade, muito ligado aos discursos ecológico, sustentável e de preservação da natureza. O terceiro é o discurso histórico, que diz respeito aos aspectos ligados à história da formação da cidade e a riqueza de seu patrimônio arquitetônico.

O discurso considerado geográfico se torna muito enfático nos mapas especialmente através dos citados slogans que estão presentes na grande maioria ${ }^{17}$ deles. Uma das idéias mais divulgadas sobre a cidade de João Pessoa é referente à sua localização como "o ponto extremo oriental das Américas". As frases que divulgam esta idéia se modificam em sua forma de escrita, no entanto, todas elas guardam a mesma pretensão do discurso. As variações encontradas nos mapas, mas que guardam o mesmo significado são: "O ponto mais oriental do continente" e a "Cidade onde o sol nasce primeiro".

A origem deste discurso está provavelmente no texto de José Américo de Almeida, escrito em 1969, que teve como finalidade a apresentação da cidade de João Pessoa na versão local da publicação das Listas Telefônicas Brasileiras ${ }^{18}$. O referido autor descreve a cidade como se estivesse caminhando por suas ruas e, na parte em que trata da sua localização geográfica, escreve que, "Perto do Cabo Branco, jaz a Praia do Seixas,

\footnotetext{
${ }^{17}$ Do total de sessenta e sete mapas analisados apenas em onze mapas não consta nenhum slogan ou frase de efeito.

${ }^{18}$ Outros autores ilustres escreveram os textos das publicações desta série de Listas Telefônicas Brasileiras (LTB) referentes à outras capitais, como Recife, escrito por Gilberto Freyre; Fortaleza, Escrito por Rachel de Queiroz e Natal, por Câmara Cascudo.
} 
extremo oriental do continente sul americano com a longitude de 34, 47' 38'”' (Almeida, 2005, p. 23).

Esta ideia tem estado muito presente no imaginário turístico da cidade circulando em todos os meios de divulgação. De caráter essencialmente geográfico, esse discurso, traz os requisitos de localização para o somatório das qualidades da cidade, fazendo com que ela se destaque de outras cidades litorâneas a partir de um atributo que a faz especialmente diferente.

No mapa 3 podemos observar um quadro (em destaque) onde foram colocados, em espaço privilegiado, os três principais discursos sobre a cidade com as seguintes frases:

"O ponto mais oriental das Américas está situado em João Pessoa, é por isso que aqui o sol nasce primeiro";

"João Pessoa é a terceira capital mais antiga do país, com um acervo histórico e cultural que vale a pena ser conhecido";

"João Pessoa é a segunda cidade mais verde do mundo, perdendo apenas para a cidade de Paris." 


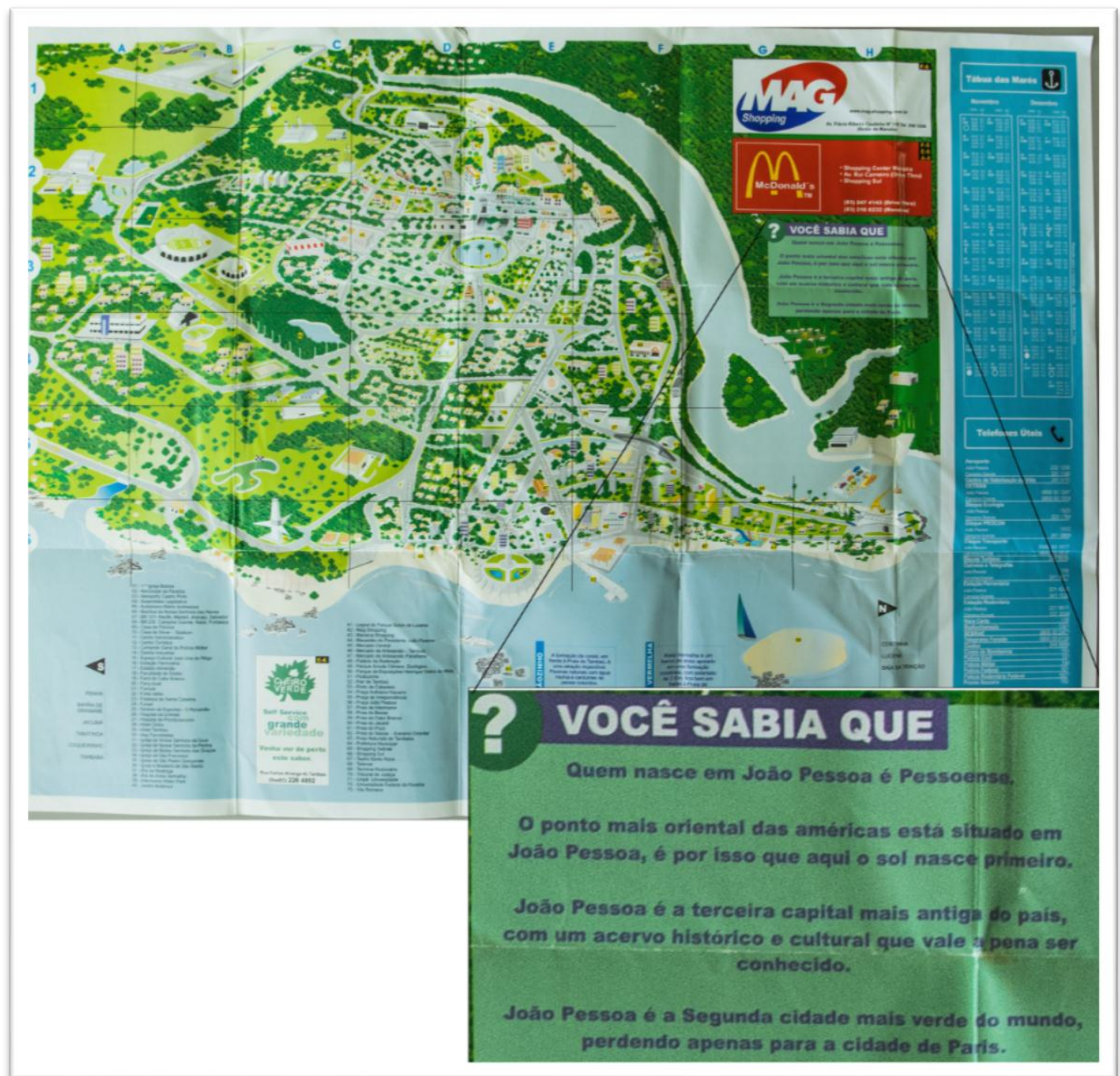

Mapa 3 - Mapa turístico de João Pessoa, com destaque para um quadro onde se lê as frases de efeito referentes aos três discursos identificados para a cidade. Data: 1999.

Compreendemos que o mapa não deve ser considerado apenas pelo conteúdo que está dentro das linhas de sua moldura, ou pela representação do espaço em si. Ele deve ser considerado como um todo, incluindo, além do traçado do espaço representado, a sua iconografia e todos os detalhes escritos. Muitos mapas vêm acompanhados de textos explicativos ou históricos sobre a área mapeada dependendo da natureza de sua temática. Nos mapas turísticos em geral esses textos são muito comuns e servem de complemento da informação que se quer passar sobre o lugar. Os textos dos mapas agregam as informações sobre o espaço que escaparam aos mapeadores. Uma espécie de garantia de que a mensagem transmitida na imagem do espaço seja compreendida. Às vezes são 
informações complementares adicionadas por aqueles que encomendam ${ }^{19}$ os mapas e servem de reforço ideológico que convence e legitima o discurso veiculado. Harley (2005) enfatiza que, nos mapas, a ideologia se encontra por toda parte, em todos os detalhes, nas dedicatórias, nas toponímias, nas cores, nas decorações, nas imagens agregadas, desenhos, os textos são a sua forma mais declarada.

Dentro da série de mapas analisados muitos contêm textos explicativos e de apresentação da cidade. A presença dos slogans é muito marcante na composição da idéia central dos textos. Os discursos identificados como, geográfico, da natureza e histórico, aparecem por vezes todos juntos em um único exemplar da cartografia turística da cidade. O mapa 4 é muito representativo no sentido de conter um texto de apresentação da cidade bem extenso.

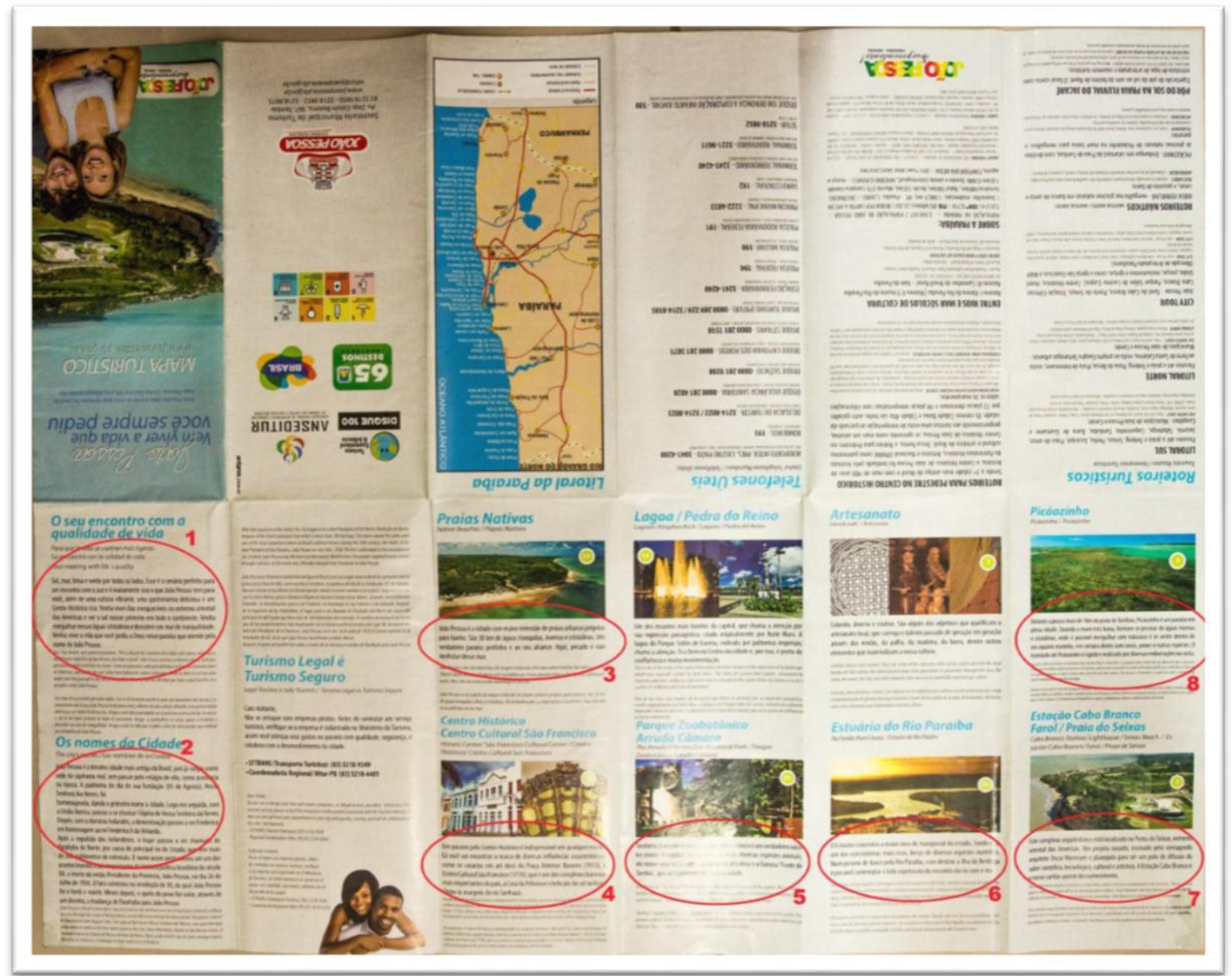

Mapa 4 -Mapa turístico de João Pessoa, com destaque para os três discursos identificados para a cidade. Data: 2010.

19 “Ahora quien solicita los mapas es un público más grande o, quizá, un grupo de interés especial, como los consumidores de mapas de carreteras, que vigilan al cartógrafo para influir sobre lo que se está registrando en el mapa" (HARLEY, 2005, p. 68). 
Neste mapa o apelo de venda da cidade abarca todas as possibilidades de representação de seu espaço através de suas três principais características, geográfica, natural e histórica. No texto de apresentação da cidade os três discursos aparecem muito fortemente. Muitas vezes com as frases de efeito repetidas em diferentes lugares. No mapa 4 destacamos com círculos vermelhos numerados algumas partes do texto de apresentação da cidade que deixam clara a presença desses discursos.

Os fragmentos do texto foram transcritos para possibilitar uma melhor visualização e compreensão do conteúdo veiculado sobre a cidade.

Fragmento do texto 1: O seu encontro com a qualidade de vida - Sol, mar, brisa e verde ${ }^{20}$ por todos os lados. Esse é o cenário perfeito para o encontro com a paz e é exatamente isso que João Pessoa tem para você, além de uma cultura vibrante, uma gastronomia deliciosa e um Centro Histórico rico. Venha viver dias inesquecíveis no extremo oriental das Américas e ver o sol nascer primeiro em todo o continente.

Fragmento do texto 2: Os nomes da cidade - João Pessoa é a terceira cidade mais antiga do Brasil, pois já surgiu como sede da capitania real, sem passar pelo estágio de vila, como acontecia na época.

Fragmento do texto 3: Praias Nativas - João Pessoa é a cidade com maior extensão de praias urbanas próprias para banho. São $30 \mathrm{~km}$ de águas tranquilas, mornas e cristalinas. Um verdadeiro paraíso pertinho e ao seu alcance. Aqui, pecado é não desfrutar desse mar.

Fragmento do texto 4: Centro Histórico - Um passeio pelo Centro Histórico é indispensável em qualquer roteiro. Lá você vai encontrar a marca de diversas influências arquitetônicas, como os casarios em art decó da Praça Antenor Navarro (1933), o Centro Cultural São Francisco (1770), que é um dos complexos barrocos mais importantes do país, a Casa da Pólvora e o belo pôr do sol no Hotel Globo às margens do rio Sanhauá.

\footnotetext{
${ }^{20}$ Grifo nosso (os destaques verificados em todos os oito fragmentos dos textos dos mapas são nossos).
} 
Fragmento do texto 5: Parque Zoobotânico Arruda Câmara - Também chamado de Bica, o parque zoobotânico é um verdadeiro oásis no centro da capital. Isso porque, além de diversas espécies animais, ele reúne uma vasta extensão de mata atlântica e a famosa "Fonte de Tambiá", que antigamente abastecia a cidade.

Fragmento do texto 6: Estuário do rio Paraíba - O estuário concentra a maior área de manguezal do estado. Sendo este um dos ecossistemas mais ricos, berço de diversas espécies marinhas. Num passeio de barco pelo Rio Paraíba, com destino a Ilha da Restinga é possível contemplar o belo espetáculo do encontro do rio com o mar.

Fragmento do texto 7: Estação Cabo Branco - Farol-Praia do Seixas Este complexo arquitetônico está localizado na Ponta do Seixas, extremo oriental das Américas. Um projeto ousado, assinado pelo consagrado arquiteto Oscar Niemeyer e planejado para ser um polo de difusão do saber científico, tecnológico, cultural e artístico. A Estação Cabo Branco é o nosso cartão-postal do conhecimento.

Fragmento do texto 8: Picãozinho - Distante a pouco mais de $1 \mathrm{~km} \mathrm{da}$ praia de Tambaú, Picãozinho é um paraíso em plena cidade. Quando a maré baixa, formam-se piscinas de águas mornas e cristalinas, onde é possível mergulhar com máscaras e se sentir dentro de um aquário marinho, em contato direto com corais, peixes e outras espécies. $O$ translado até Picãozinho é rápido e realizado por diversas embarcações na costa.

Verificamos que a mesma idéia é reproduzida entre os mapas e repetida como se fosse uma espécie de eco que se propaga através das publicações. Em muitos mapas a idéia se repete várias vezes, numa espécie de reforço ideológico que tenta, de forma persistente, reafirmar a veracidade da informação. Este fato pode ser verificado no mapa 4, especificamente nos trechos transcritos nos fragmentos 1 e 7 nos quais aparece mais de uma vez o discurso geográfico do "extremo oriental das Américas".

Além da repetição dos discursos muito presente nos mapas analisados, foi possível perceber que, ao longo das publicações, algumas frases de efeito foram confundidas e 
reproduzidas erroneamente. Em um dos mapas analisados ${ }^{21}$, por exemplo, aparece o slogan “... a segunda capital mais verde do Brasil”. Da mesma forma, em outro mapa também ocorre um equívoco semelhante quando a frase afirma ser João Pessoa "Acidade mais verde do Brasil e a segunda mais verde do mundo". No entanto, o equívoco mais marcante, foi identificado em um mapa ${ }^{22}$ em que o slogan apresenta João Pessoa como "a cidade mais verde das Américas". Cabe lembrar que a origem desse discurso apresenta a cidade como "a segunda cidade mais verde do mundo...".

Outros equívocos são comuns como, por exemplo, localizar de forma errada "o ponto mais oriental das Américas" como sendo na Ponta do Cabo Branco. Leandro (2006) demonstrou, em algumas matérias de revistas, esta mesma confusão entre a Ponta do Seixas e a Ponta do Cabo Branco. Alguns materiais publicitários citam a Ponta do Seixas como "o ponto mais oriental", no entanto apresentam uma fotografia da Ponta do Cabo Branco.

A ideia de João Pessoa como uma "cidade verde" tem estado bastante presente no imaginário dos paraibanos desde o início da década de 1990, quando, durante a ECO 92, o Governo do Estado divulgou a cidade como a "segunda cidade mais verde do mundo". Este discurso, da mesma forma que o discurso do ponto mais oriental das Américas, também está presente no texto de José Américo de Almeida e, provavelmente é possível que também esteja aí a sua origem. Em suas palavras José Américo de Almeida destacou uma predominância, na época, de áreas verdes na cidade, afirmando que "vista do alto, João Pessoa aparece mergulhada num bosque. A presença da árvore nas praças, nas ruas, nos jardins e nos quintais dá-lhe uma aparência mais vegetal do que urbana. O verde está espalhado em toda parte; a folhagem é sua melhor pintura" (Almeida, 2005, p. 11).

Analisando ainda os discursos do mapa 4, podemos verificar, nos fragmentos destacados do texto que, além de apresentar os três discursos principais (geográfico, natural e histórico), vários outros podem ser identificados por meio de palavras ou de frases. Percebemos neste caso, os discursos da paz da tranqüilidade e da sedução também identificados na concepção geral do marketing turístico da cidade.

\footnotetext{
${ }^{21}$ Mapa disponível nos apêndices - Ficha 44.

${ }^{22}$ Mapa disponível nos apêndices - Ficha 16.
} 
O discurso da paz e da tranqüilidade esteve presente nas propagandas da cidade e foi derivado das políticas de desenvolvimento do turismo vinculadas ao Plano Amanhecer, cujas estratégias de marketing para a promoção da cidade centravam-se nas ideias de tranqüilidade e segurança (LEANDRO, 2006, p. 151), diferencial muito desejado para pessoas provenientes de grandes cidades.

Percebe-se que, em muitos momentos, o marketing turístico de João Pessoa e do litoral se confunde com o do restante do Estado muito em decorrência dos dois terem sido elaborados de forma articulada pela mesma equipe e na mesma época (LEANDRO, 2006). No entanto, ao observar o que está expresso nos mapas sobre esta situação, é notória a ênfase dada à cidade de João Pessoa e ao litoral, apesar de existirem no interior do Estado vários lugares de importância histórica, natural e arqueológica.

Considerando a cidade de João Pessoa como o destino inicial de quem chega à Paraíba, observamos poucos mapas turísticos do Estado como um todo, sendo a maioria desses mapas colocados como figura anexa do mapa principal, em tamanho menor, disposta em lugar desprivilegiado da publicação cartográfica como um todo. Este fato pode ser percebido em diversos mapas da série analisada, como no mapa 5 que serve de exemplo e apresenta bem claramente essa tendência.

Este material, apresentado no mapa 5, trata-se de um folder dobrável e impresso em dois lados. Na parte superior da figura está o mapa principal que, mesmo apresentando o título "A Paraíba e seus encantos", representa apenas cidade de João Pessoa. Na parte inferior da figura está o lado oposto do folder, no qual visualizamos o mapa do Estado em meio a diversas informações e propagandas de estabelecimentos do comércio da cidade. 


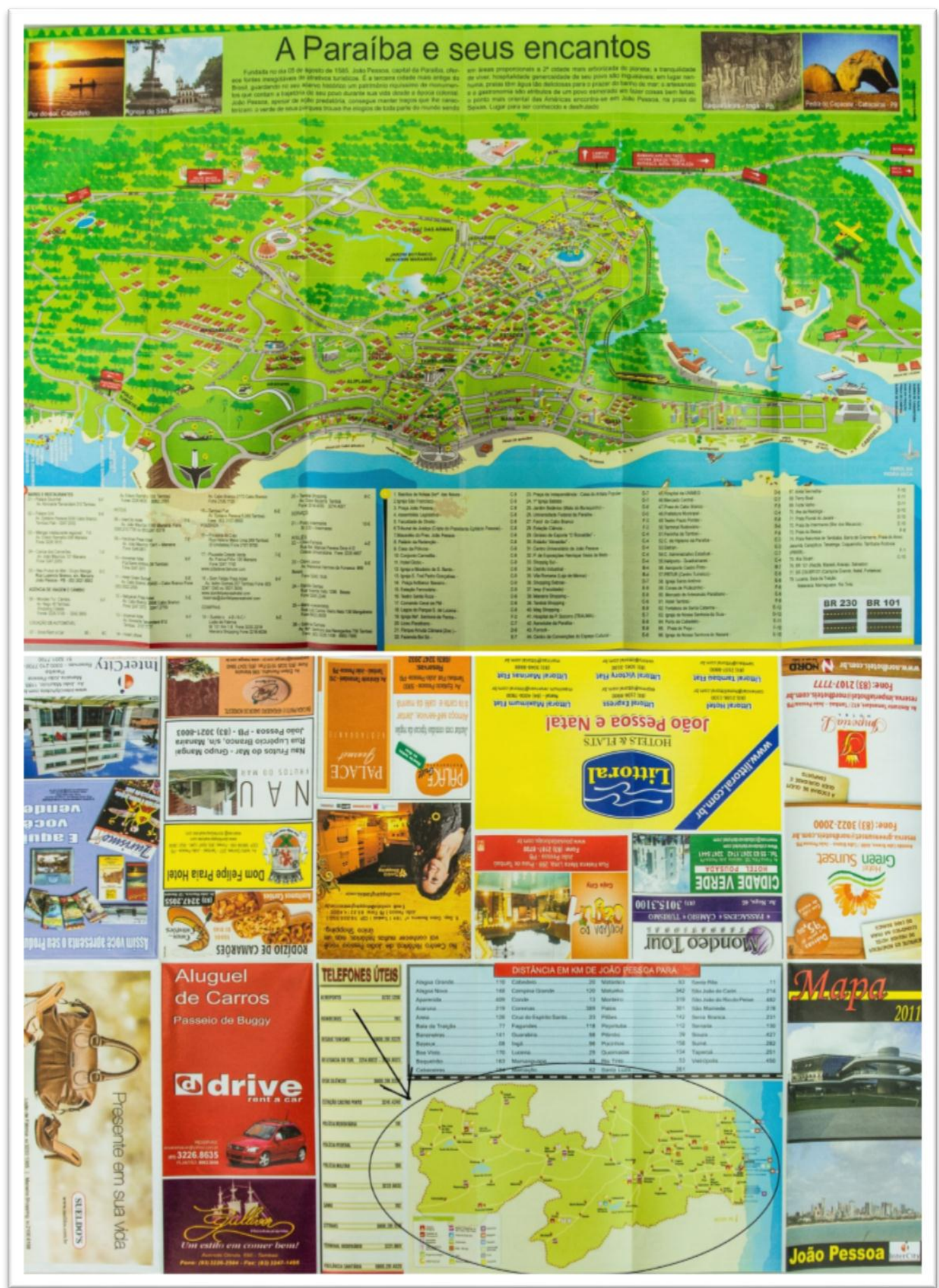

Mapa 5 - Mapa "A Paraíba e seus encantos". Material impresso em formato de folder dobrável. A parte superior da ilustração acima apresenta o mapa principal e a parte inferior apresenta o lado oposto onde fica a capa do folder e outras informações. Data: 2011. 
Outros mapas também são ilustrativos dessa questão, como o mapa 6 que faz a divulgação turística da Paraíba numa revista de circulação nacional. O referido mapa apresenta o título "Descubra a Paraíba", no entanto, a área representada se restringe apenas ao litoral do Estado.

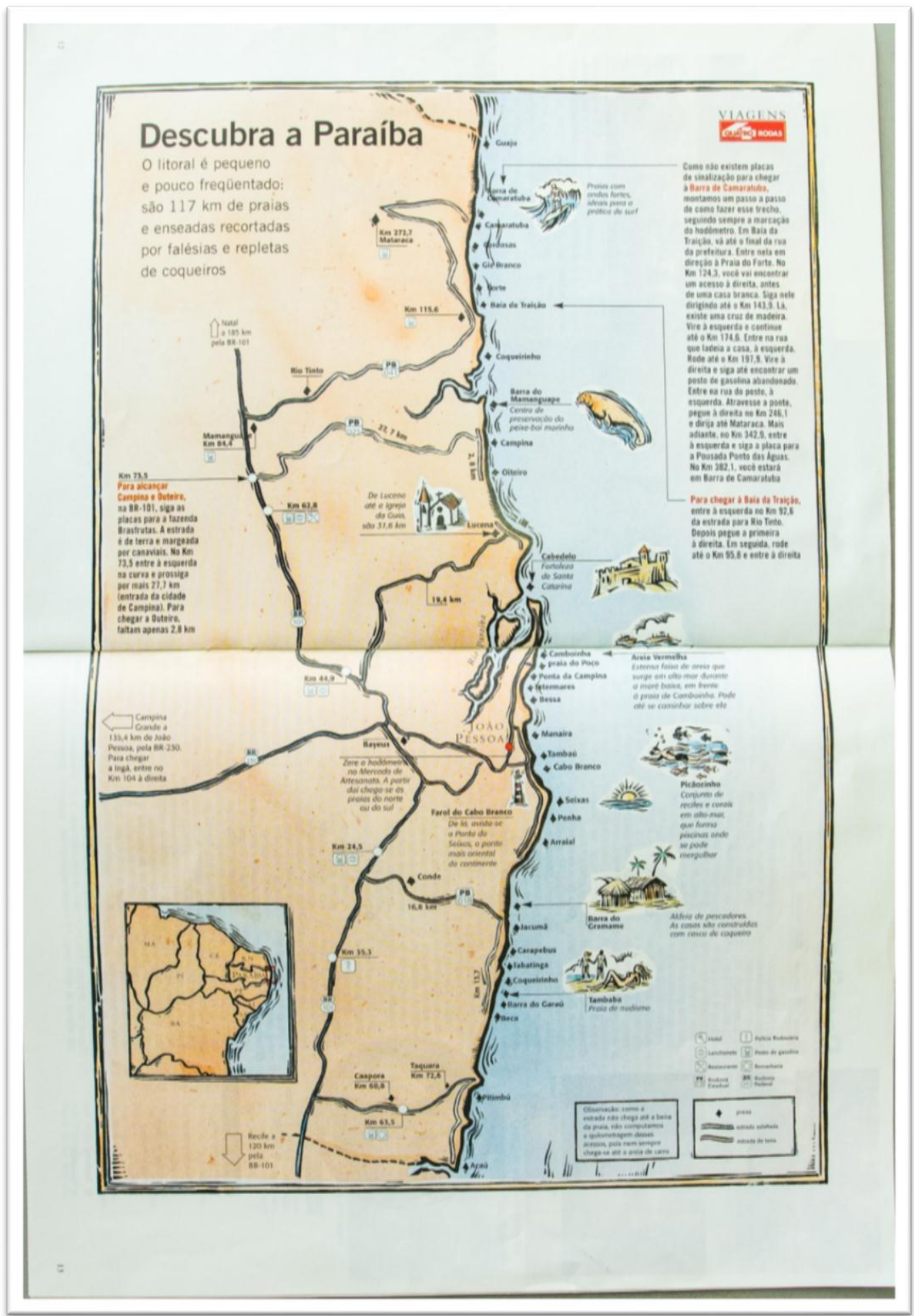

Mapa 6 - Mapa Descubra a Paraíba. Encarte extraído da revista Quatro Rodas de maio de 1996. 
Neste sentido, o mapa 7 é bem interessante, pois, mesmo contendo um espaço amplo no interior do folder para a disposição de um mapa do Estado com um bom tamanho e numa escala apropriada, a opção foi a de colocar um mapa ilustrativo, pequeno, sem detalhes e sem nenhum atrativo para o turista. Carente até mesmo das informações básicas necessárias para guiar um visitante num percurso pelo Estado. Neste folder, a cidade de João Pessoa, apesar de não ter um mapa de sua área, aparece na capa, em local privilegiado, sendo destaque através de fotografias de seus principais locais de interesse para os turistas.
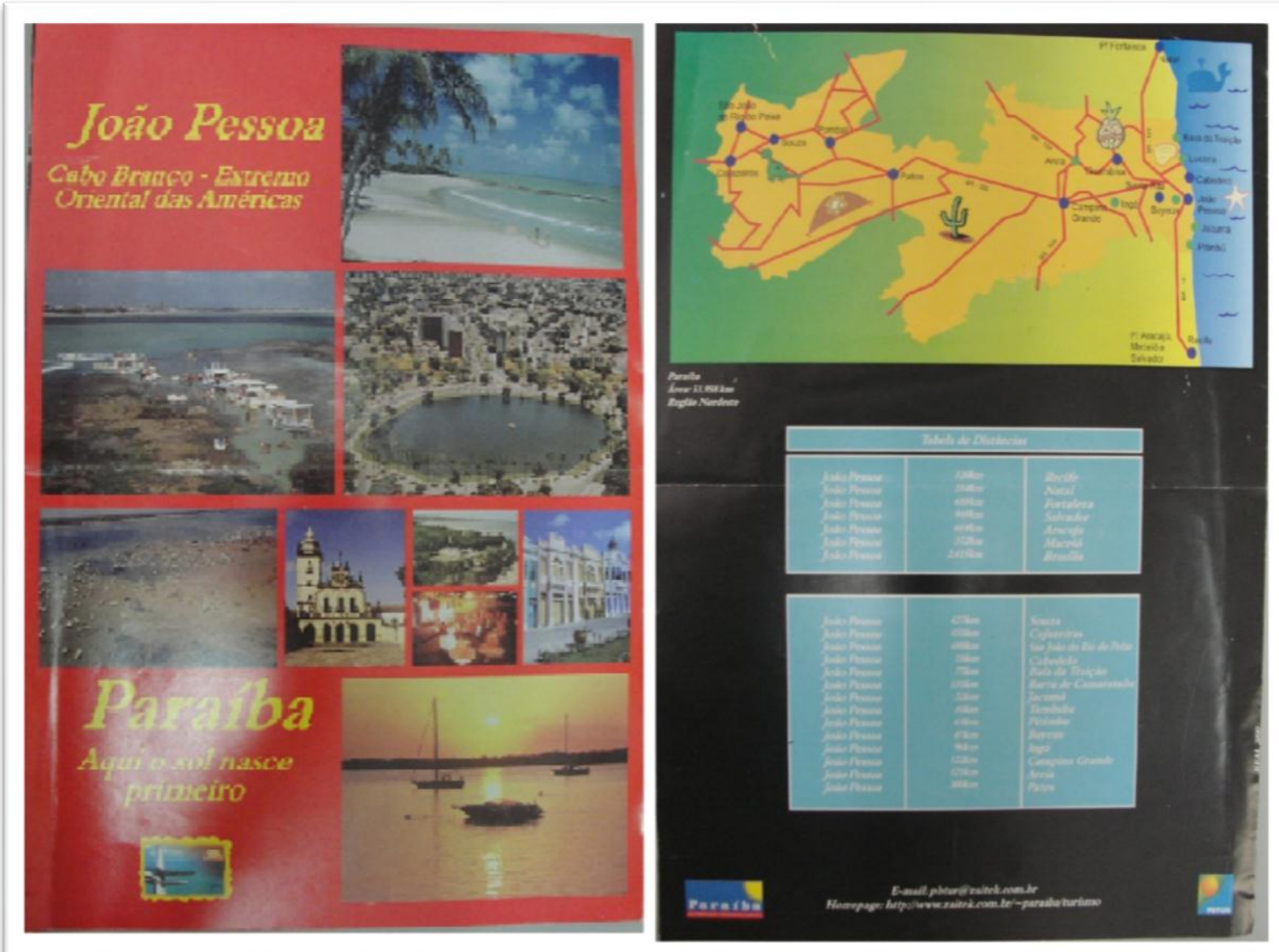

Mapa 7 - Mapa Paraíba aqui o sol nasce primeiro. Material impresso em formato de folder dobrado ao meio. No lado direito da ilustração pode ser vista a parte interior do folder onde consta um mapa do Estado em tamanho reduzido e sem muito detalhamento de seus atrativos turísticos. Na capa, vista do lado direito da ilustração, vê-se várias fotografias da cidade de João Pessoa. Data: 1996. 


\section{3 - O Parque Sólon de Lucena e o Hotel Tambaú: símbolos materiais do discurso turístico da cidade}

Os mapas turísticos são uma boa fonte de investigação de mensagens subliminares ou mesmo declaradas, na medida em que, são fortemente marcados por cores, imagens e muitas decorações. De uma forma aparentemente despretensiosa, esses mapas são capazes de legitimar discursos que, muitas vezes, representam relações territoriais de poder muito desiguais. Percebemos que a força política, financeira e de status quo de capital do Estado da Paraíba faz com que João Pessoa esteja muito presente nos discursos, nas publicidades e divulgações turísticas. Assim, outras cidades do Estado, com locais de potencial interesse turístico, acabam sendo esquecidas e quase eliminadas totalmente do marketing turístico do Estado, bem como dos materiais publicitários e de outras mídias ligadas ao setor.

Os mapas da mesma maneira que outra forma discursiva, como os livros, por exemplo, se tornaram uma força política com alto poder de atuar de forma eficiente no nível simbólico da realidade. A partir do momento em que a mensagem cartográfica se impregna de poder, ela passa a operar tanto em nível consciente, quanto inconsciente. De acordo com o autor, frequentemente neste nível abstrato o poder político se reproduz, comunica e atua de forma mais eficaz (HARLEY, 2005, p. 85).

O capitalismo se utiliza de todos os meios mais eficientes para apropriação de tudo o que for possível, inventando e reinventando o mundo de acordo com seus interesses. $\mathrm{O}$ capital atribui valor a praticamente tudo. E isso é possível por meio das preferências estéticas (gosto) derivadas de relações entre os diversos grupos sociais. Cada grupo valora coisas diferentes e tem seus estilos e preferências próprias. Estes aspectos de caráter essencialmente psicológicos levam as pessoas a realizar manifestações simbólicas que terminam por influenciar suas condutas com relação ao consumo e outras práticas.

As representações simbólicas estão cada dia mais poderosas e determinantes nas escolhas e nos comportamentos das pessoas. Os signos passam a substituir a realidade, representando-a em seu lugar. Neste caso, os ícones encontrados nos espaços são exemplos contundentes de como as construções simbólicas são poderosos elementos que demarcam a presença do poder estabelecido. Nos mapas, assim como no espaço real, 
esses ícones que são "[...] valorizados na paisagem urbana contemporânea parecem ganhar esta autonomia de estátuas que nos vigiam para sermos reproduzidos por elas" (LUCHIARI, 2005, p. 96).

Em João Pessoa podemos apontar alguns símbolos muito presentes no imaginário da população: a Lagoa do Parque Solon de Lucena, o Hotel Tambaú, o Farol do Cabo Branco, a Igreja de São Francisco, o Hotel Globo e o mais novo, ainda em processo de construção simbólica, mas já muito presente no imaginário local, a Estação Ciências. Vamos considerar, para esta análise, a Lagoa do Parque Solon de Lucena e o Hotel Tambaú por ser, dentre os citados, os dois mais significativos, o primeiro pelo tempo de existência simbólica e de aparições em cartografias antigas ${ }^{23}$ da cidade, e o segundo pela estreita ligação com o turismo da cidade.

Em João Pessoa esses símbolos aparecem de forma marcante por toda a cidade, atuando como centralizadores de reafirmação do poder sobre o espaço. O Parque Solon de Lucena (Lagoa) é uma das principais referências da cidade atualmente. No passado já foi empecilho ao crescimento da cidade, mas depois de urbanizada se transformou em centro de articulação entre a cidade antiga e a cidade "futura" (ALMEIDA, 2006). Até hoje a Lagoa atrai grande parte do fluxo diário da cidade, a vitalidade de João Pessoa se reflete naquele espaço. A Lagoa já foi considerada também como o ponto central da cidade, e realmente o foi até aproximadamente o anos de 1972 (ver mapa 2), quando a cidade ainda apresentava um tímido crescimento de seu tecido urbano. Com o crescimento mais acelerado, notadamente a partir da década de 1980, iniciaram-se as transformações que engendraram novas centralidades em outras áreas da cidade como, Mangabeira, Manaíra, Cristo e Cruz das Armas, para citar apenas alguns bairros. No entanto, o centro de João Pessoa, simbolicamente marcado pela conhecida Lagoa do Parque Sólon de Lucena continua a manter seus aspectos de centralidade urbana (SALES, 2009).

Nos mapas turísticos verificados a Lagoa ainda permanece como o ponto central da cidade (no que se refere à sua posição relativa no espaço da cidade). Elegemos o mapa 8 para demonstrar este fato, onde visualizamos a Lagoa bem no centro do mapa. Outro

\footnotetext{
${ }^{23}$ A Lagoa já era representada desde o século XVII na cartografia constante em Barleus (1647) e em J. Vingboons (1660 e 1665) (ALMEIDA, 2006).
} 
fato que merece destaque é que a Lagoa está representada através de um símbolo com uma proporção muito exagerada em relação à Mata do Buraquinho ${ }^{24}$ e à Bica $^{25}$, que possuem 515 e 26,4 hectares respectivamente.

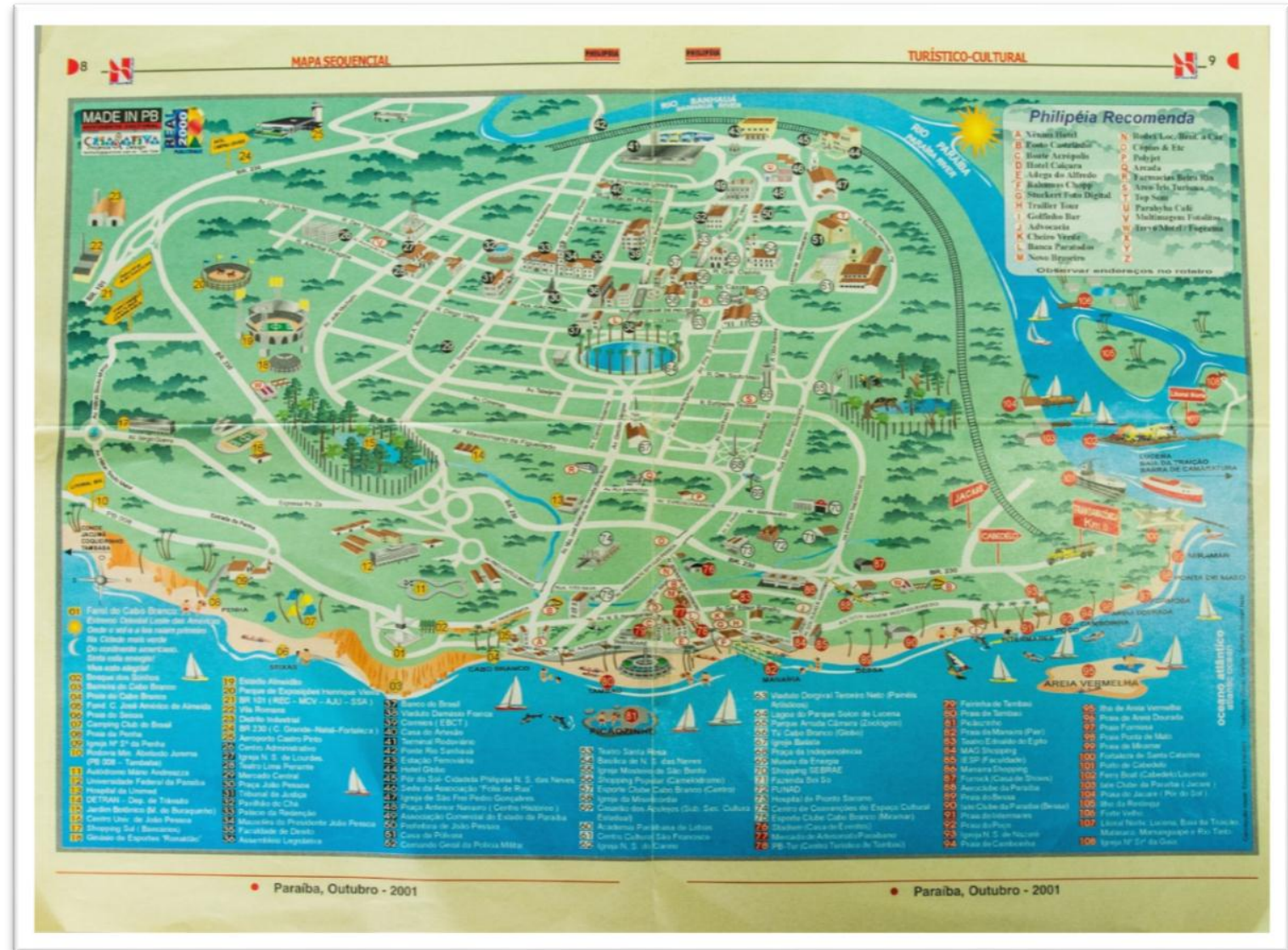

Mapa 8 - Mapa-encarte da Revista PHILIPÉIA. Data: 2001. Acervo: PBTUR.

Na imagem de satélite da figura 2 (página 105), podemos fazer uma comparação dos tamanhos relativos desses três locais da cidade, e perceber a dimensão do exagero. Claro que as distorções e os exageros são comuns em mapas deste tipo, mas essa tendência foi muito recorrente na série de mapas e verificada em 22 deles.

${ }^{24}$ O Jardim Botânico, também conhecido como Mata do Buraquinho, é uma área remanescente de mata atlântica localizada em meio à área urbana da cidade.

${ }^{25}$ O Parque Zoobotânico Arruda Câmara, conhecido como Bica, foi tombado em 1941 pelo Instituto do Patrimônio Histórico e Artístico Nacional (IPHAN) e, em 1980, foi tombado pelo Instituto do Patrimônio Histórico e Artístico do Estado da Paraíba (IPHAEP). 
A figura 3 apresenta algumas capas de mapas em formato de folders dobráveis em que a Lagoa é o destaque.
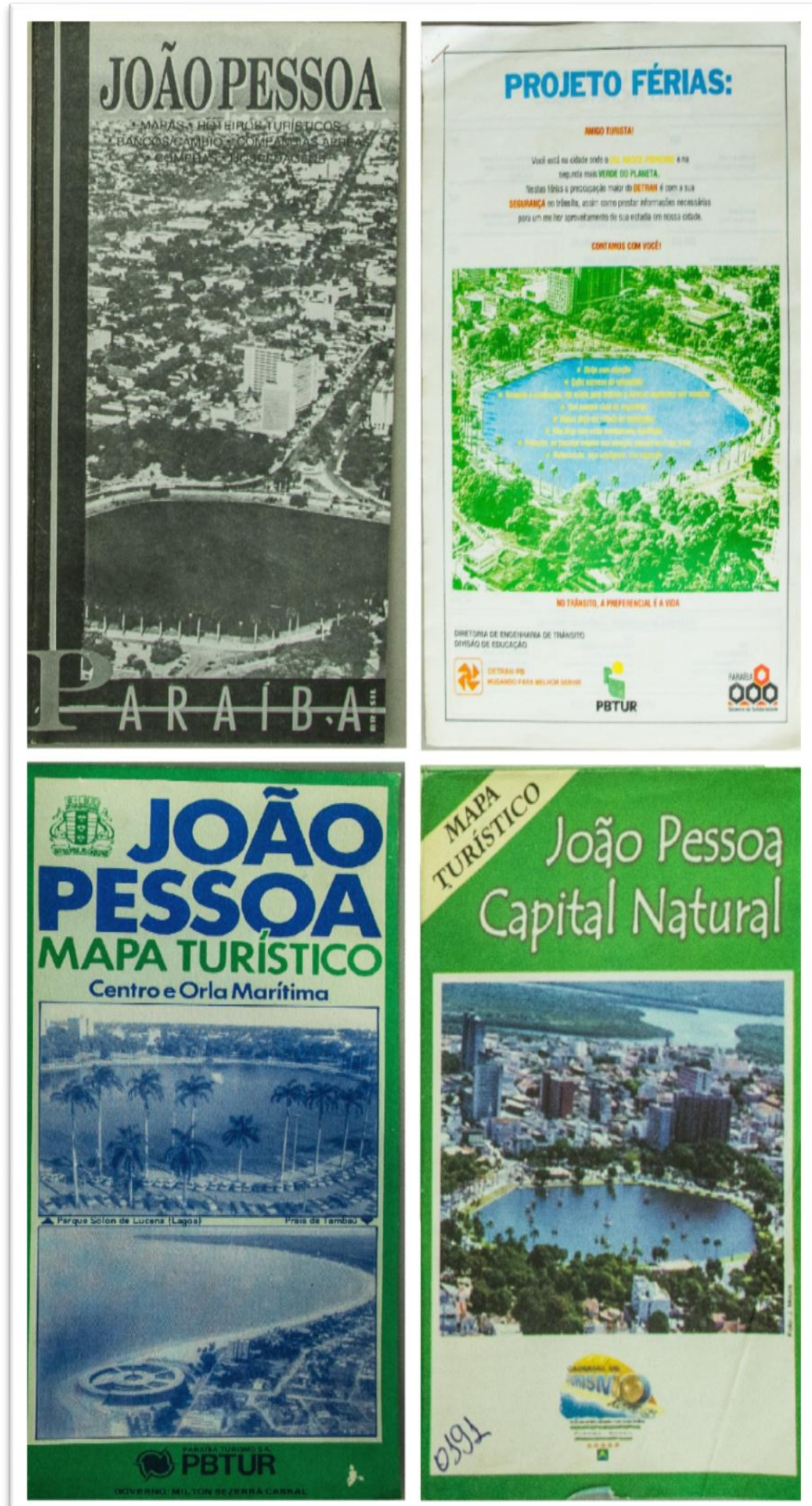

Figura 3 - Capas de mapas com fotografias em que a Lagoa é colocada como destaque principal. 
A importância simbólica ${ }^{26}$ da Lagoa do Parque Solon de Lucena talvez esteja no fato de que ela representa um dos primeiros passos para passagem da cidade tradicional e antiga (MAIA, 2000) para uma cidade renovada. Este parque representa o marco desse momento em que a cidade se insere nos preceitos de modernidade e salubridade, se tornando, então, uma representação do êxito de um conjunto de reformulações urbanas postas em prática na mesma. $\mathrm{O}$ poder sobre o espaço naquele momento teve respaldo através das ciências que legitimaram as ações de disciplinamento e urbanização, com a atuação de alguns urbanistas que deixaram contribuições por todo o país. Dois importantes nomes estão vinculados à história desse espaço, Saturnino de Brito, engenheiro que foi responsável pelas obras de saneamento, e Burle Marx, responsável pelo paisagismo do parque.

Essa hierarquia visual dos símbolos tem sido uma prática muito utilizada historicamente pela igreja e pelo Estado no mundo todo. Os monumentos religiosos são um dos exemplos reais da expressão no espaço desta demarcação do poder instituído, onde a grandiosidade reafirma uma capacidade infinita e sagrada de impor e influenciar decisões.

O papel dos mapas como proclamadores do status quo do poder pode ser reforçado pelos sistemas de classificação e pelos signos estabelecidos ou convencionais da cartografia. Muitos mapas apresentam uma hierarquia visual muito perversa de seus símbolos, demarcando áreas ou cidades de acordo com uma classificação de importância econômica ou política que afeta a percepção das pessoas sobre o espaço. Os mapas de hierarquia de cidades utilizados nos livros escolares são exemplo deste fato, em que os signos maiores reafirmam o poder hegemônico de algumas áreas, como se as outras representadas por signos de menor tamanho ou valor não tivessem nenhuma importância dentro do contexto dessas cidades. Historicamente essas práticas foram muito freqüentes entre antigos cartógrafos que atribuíam signos tão grandes para os castelos que muitas vezes eram maiores que povoados inteiros (HARLEY, 2005, p. 98).

\footnotetext{
26 A Lagoa foi escolhida como cartão postal da cidade pela população através de um concurso realizado na passagem de seu $422^{\circ}$ aniversário tendo concorrido com o Farol do Cabo Branco, o Hotel Tambaú, a Orla do Cabo Branco e a Igreja de São Francisco (PAULINO, 2010).
} 
Outro símbolo muito presente no imaginário da cidade, e que tem lugar privilegiado nos mapas turísticos, é o Hotel Tambaú, construído com a função de fomentar o turismo na cidade que ainda não contava com uma estrutura receptiva para um público que começava a chegar, principalmente atraído pela pesca e pelo corte das baleias, que ainda eram muito numerosas no litoral da Paraíba.

Na visão do conjunto dos mapas percebemos que o Hotel Tambaú tem sido apresentado como um dos principais pontos turísticos dentro da hierarquia das representações sobre a cidade turística a ser mostrada. O mapa 9 é bem apropriado para demonstrar isso. Percebemos que o ponto de vista de quem está olhando o mapa é no sentido de oeste para leste, como se a pessoa estivesse de costas para a cidade antiga e para o centro da cidade, com a visão voltada para a área da orla marítima. O destaque é o Hotel que foi colocado no centro do mapa, numa posição privilegiada que dá a impressão que o mesmo se encontra no centro de tudo e em um nível acima dos outros elementos mapeados.

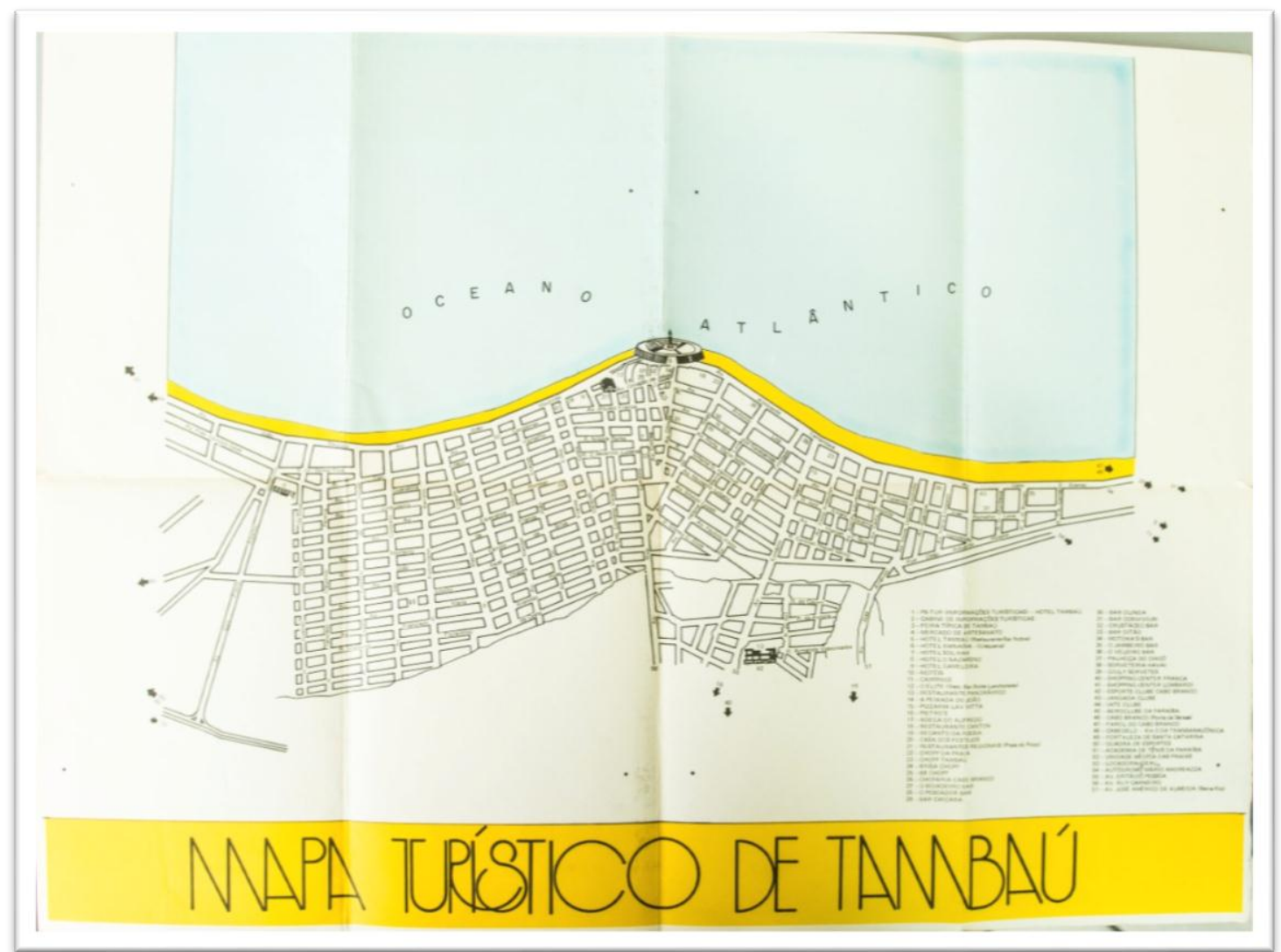

Mapa 9 - Mapa Turístico de Tambaú. Acervo: PBTUR. Data: período aproximado de 1987 a 1991. 
A ênfase da informação deste mapa se concentra no hotel que provavelmente à época era a principal estrutura turística da cidade. É clara a intenção de colocar a representação de um poder econômico ligado ao turismo ocupando uma posição central. O centro do mundo sempre foi uma localização muito disputada no contexto simbólico do poder, assim, o centro do mapa se transforma no lugar da mais alta importância para a hierarquia dos lugares mapeados.

De modo geral, na cidade de João Pessoa poucas mudanças ocorreram do ponto de vista turístico até 1970, época em que a atividade se confundia, em grande parte, com "serviço de hotelaria"27. A criação da Embratur, em 1966, trouxe a possibilidade de mudanças estruturais com grandes financiamentos voltados para a atividade nas cidades brasileiras. Na Paraíba a obra que inaugurou este período foi a construção deste hotel, o Tropical Hotel Tambaú, que foi erguido à beira mar na praia de Tambaú. Projetado pelo arquiteto Sérgio Bernardes, com uma arquitetura arrojada para a época, esta obra se caracterizou por uma interferência grandiosa e isolada dentro do contexto do fomento ao turismo. Depois de pronto e inaugurado, em 1971, Leal (2001) cita uma grande dificuldade que os administradores tiveram de encontrar mão de obra qualificada para o seu funcionamento. Faltaram outras ações conjuntas que melhorassem o desempenho e a oferta do turismo na cidade, principalmente ligadas à infra-estrutura e capacitação de pessoal.

Percebemos para o Hotel Tambaú as mesmas estratégias que foram utilizadas no caso da Lagoa do Parque Solon de Lucena de exagerar nos tamanhos dos signos de representação. Os mapas 10 e 11 são exemplos do uso de hierarquias de signos para reafirmação de um nível de importância que um lugar ou um monumento apresenta dentro do contexto simbólico dos discursos. Percebemos em ambos os mapas que o tamanho do signo que representa o hotel é excessivamente desproporcional ao seu tamanho real.

\footnotetext{
${ }^{27}$ Segundo Leal (2001) na década de 1950 todos os hotéis, pensões, dormitórios, pensionatos, hospedarias estavam localizados na área próxima ao centro da cidade, ou na parte mais antiga da cidade. Portanto, não existia nenhum hotel que hospedasse turista em nenhuma praia da orla da cidade. $\mathrm{O}$ autor cita que vinte e oito hotéis funcionavam na cidade em 1976 e destes apenas dois estavam instalados na orla marítima.
} 


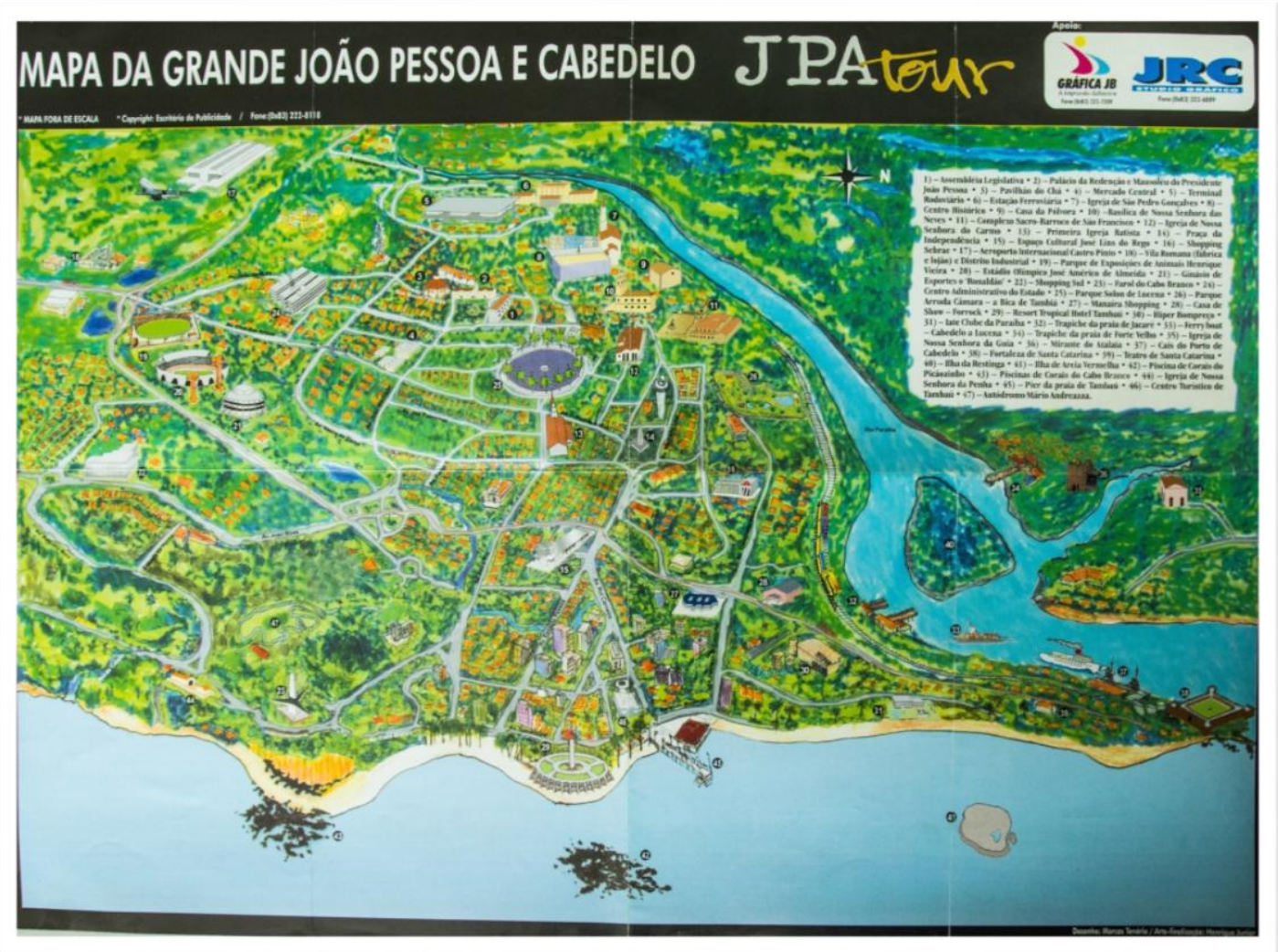

Mapa 10 - Mapa da Grande João Pessoa e Cabedelo. Em destaque o Hotel Tambaú e a Lagoa do Parque Sólon de Lucena. Data: 1990. Acervo: PBTUR.

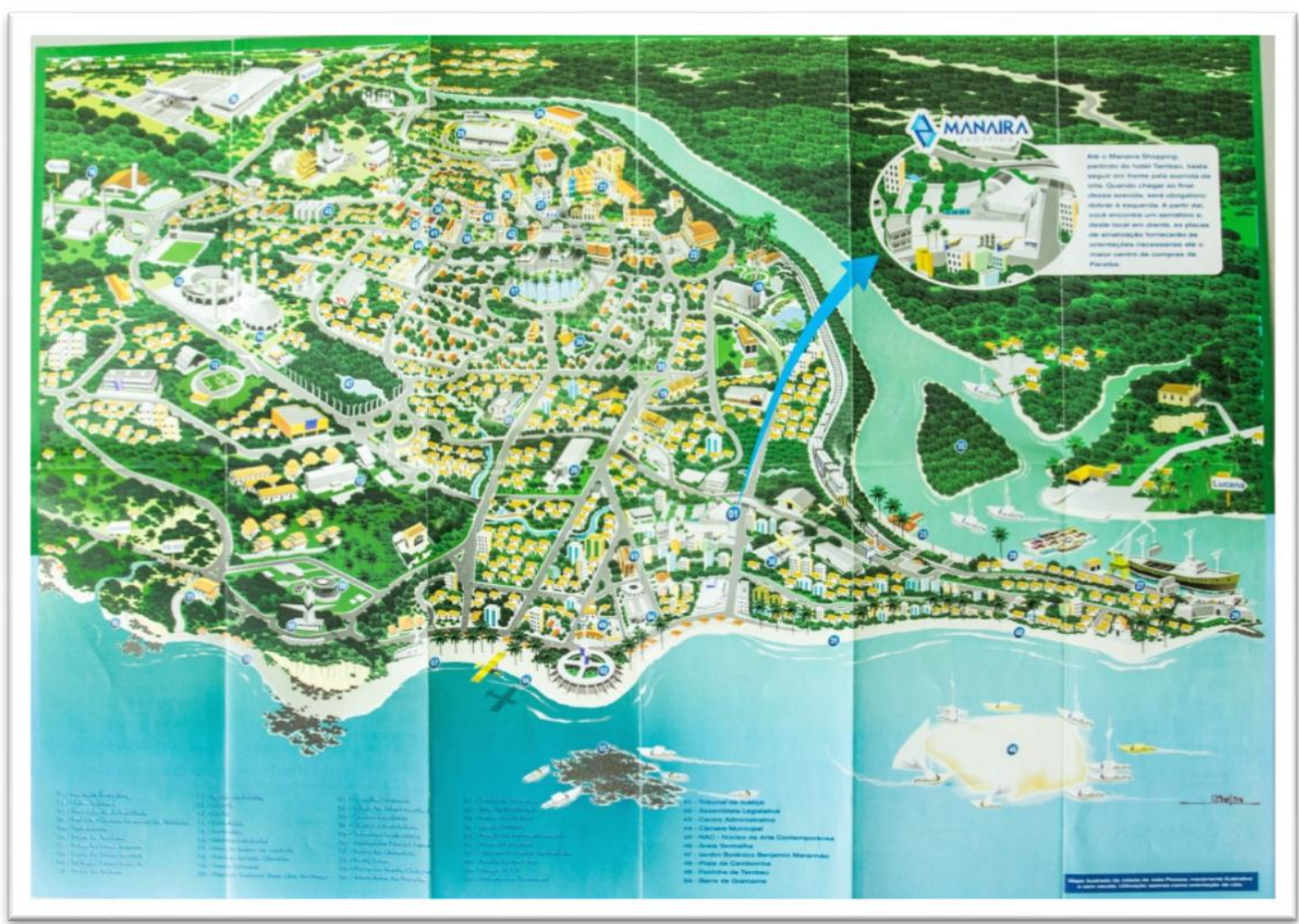

Mapa 11 - Material publicitário do Manaíra Shopping em formato de folder com um mapa turístico de João Pessoa. Data: 2009. Acervo: PBTUR. 


\section{4 - O lugar das propagandas nos mapas}

Levando em conta uma certa linearidade no tempo das publicações pode ser percebida uma evolução da qualidade gráfica destes mapas no decorrer de alguns anos, com a presença de mais cores, a introdução de fotografias, a melhoria da qualidade do papel e das impressões. Podemos inferir que essas mudanças são decorrentes de progressos técnicos verificados no setor gráfico de um modo geral, além do aumento no nível de capacitação dos designers gráficos. No que se refere ao contexto do cartógrafo de mapas turísticos na atualidade, Uller (2010) se refere ao setor de marketing como principal agente na sua produção, cuja demanda é amplamente voltada para os interesses do mercado turístico.

Para os mapas considerados neste estudo podemos destacar a falta de aspectos técnicos da cartografia como algumas normas cartográficas básicas. Dentre os mapas observados apenas três apresentaram a escala, que é um requisito básico e essencial para qualquer tipo de representação que leve em conta uma referência de localização e tamanho de um objeto ou espaço. Sobre os mapeadores dos mapas turísticos da cidade de João Pessoa, apenas em um consta a indicação de ter sido elaborado por geógrafos. Os demais mapas, ou não apresentaram os responsáveis pela criação, ou foram criados por designers gráficos ligados às empresas de publicidade e de promoção cultural da cidade.

Os mapas não são apenas o traçado da cidade, a topografia, ou outra característica física do espaço, eles agregam em si diversas outras dimensões abstratas do espaço, os fluxos, as idéias, os conflitos, as convergências, aspectos que terminam por fazer parte, de alguma forma, do seu produto final. Os mapas são uma síntese simbólica de um complexo de idéias, ações e situações ligadas ao espaço, eles são um resumo imagético e gráfico do poder social e econômico. Nas suas representações os mapas sempre utilizaram de elementos decorativos para compor a sua imagem e repassar a mensagem, mas é bom lembrar que nenhum elemento no mapa está posto por acaso, até mesmo os seus adornos ou enfeites (Harley, 2005).

Os mapas turísticos de João Pessoa há tempos já incorporaram outras informações além da representação do traçado da cidade. É perceptível uma apropriação gradativa dos espaços dos mapas por propagandas de produtos e serviços ligados ao mercado do turismo. O capital invade até os espaços virtuais se apropriando deles e os transformando 
também em mercadoria. Percebemos que, em algum momento, o espaço do mapa também passou a ser "loteado" e vendido, sendo valorizado de acordo com o tamanho e a localização do "lote".

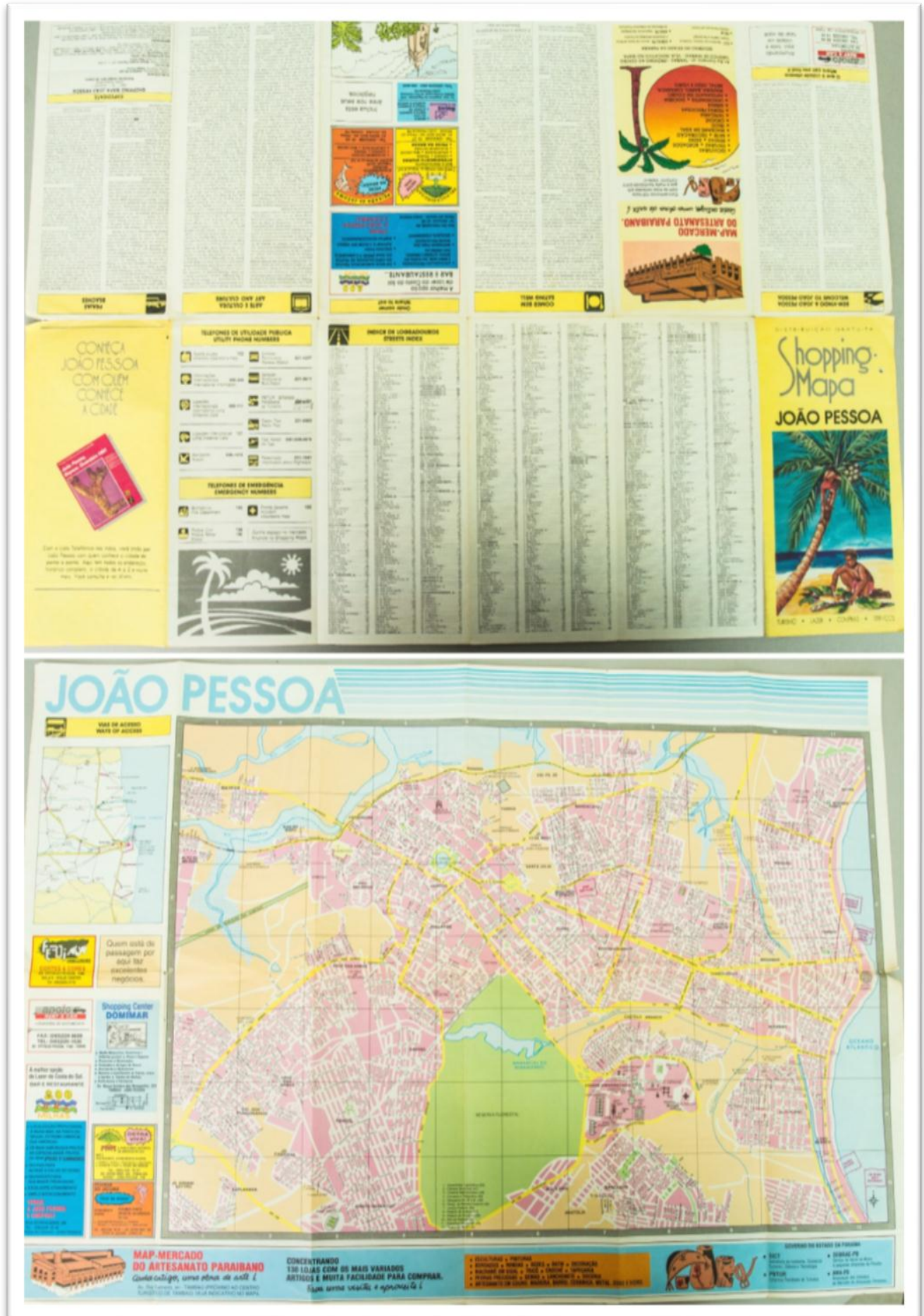

Mapa 12 - Shopping Mapa João Pessoa. Material impresso em formato de folder, contendo um mapa com publicidades nas margens. A parte superior da figura demonstra o lado onde constam informações turísticas, algumas propagandas e a capa do folder e na parte inferior está o mapa. Data: 1991. Acervo: PBTUR 
Os espaços desses mapas começam a ser ocupados por propagandas a partir da década de 1990, quando aparecem as primeiras publicidades de empresas que iniciam a divulgação de suas marcas no interior dos mapas. O mais antigo encontrado com essa característica data de 1991 e podemos observá-lo no mapa 12, que se apresenta em formato de folder dobrável, constando em um dos lados um mapa da cidade e, do outro lado, informações turísticas e publicidades. Percebemos que neste mapa da cidade a borda inferior e a lateral esquerda estão preenchidas com publicidades. No entanto, são poucas empresas anunciantes, além do Shopping Manaíra, MAP (Mercado de Artesanato da Paraíba), Rent a car (Locadora de automóveis), Roccas (Bar e restaurante), Peixada do Jacumã (Restaurante), Palhoça do Seixas (Restaurante) e 200 Milhas (Bar e restaurante).

A partir dos anos de 2000 as propagandas se multiplicam gradativamente nos mapas. Afinal a valorização do espaço se dá tanto pela sua produção material, através de um conjunto de benfeitorias construídas que lhe agrega valor monetário, como também por uma valoração que consiste na formação de uma imagem simbólica positiva deste espaço (MORAES, 2007). Aos mapas cabe, também, além de veicular as qualidades do espaço a ser consumido pelo turista, atestar a presença desses valores agregados a esse espaço. Torna-se necessário agora informar as facilidades comerciais desta área, bancos, hotéis, restaurantes, locadoras de automóveis, bares, shoppings, dentre outros serviços facilitam a vida do turista durante a estada na cidade.

$\mathrm{Na}$ série de mapas analisados identificamos um aumento significativo na quantidade de propagandas, principalmente a partir do ano 2000. De forma que, em muitos mapas, a grande quantidade de anúncios publicitários acaba por ofuscar o mapa e o espaço da cidade representada, chegando ao ponto de "invadir" o espaço virtual da cidade no mapa (ver mapa 13).

A decoração nos mapas antigos que, antes, era marcada por "emblemas, escudos e armas", atualmente se transforma em acúmulo de propagandas que chamam os leitores a consumir o espaço e as coisas no espaço. Os mapas turísticos de João Pessoa passaram a fazer parte, de forma mais efetiva, de uma rede organizada para o consumo em que o turismo é o mote principal. 


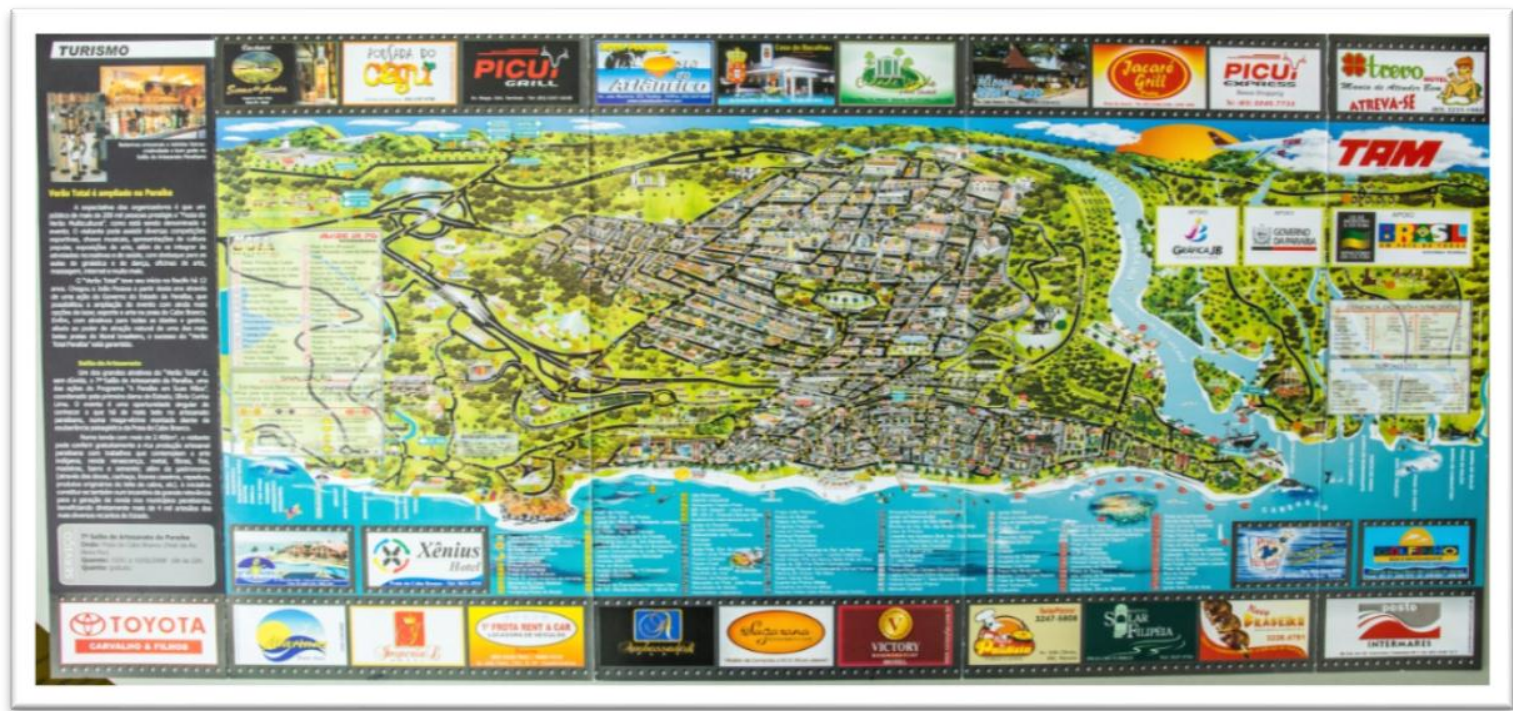

Mapa 13 - Mapa-Guia turístico de João Pessoa. Toda a moldura do mapa composta de propagandas. Data: 2008. Acervo: PBTUR.

\section{5 - João Pessoa: a cidade invisível}

Sobre o silêncio Harley (2005) afirma que, em qualquer tipo de expressão, seja por signos, sons, gestos ou marcas, está contido um silêncio que oculta as coisas. Os mais óbvios são os que ocorrem no discurso e na música, mas também se dão nas artes em que não se atuam como na pintura e na escultura e semelhantemente ocorre nos mapas. Tudo aquilo que não está posto no mapa deve ser considerado tanto quanto aquilo que está. $\mathrm{O}$ silêncio é um dos veículos do discurso e pode ser realizado, tanto pelo opressor, como pelo oprimido, guardando, claro, as especificidades de cada caso (ORLANDI, 1997).

Em nossa perspectiva, mesmo as características menos importantes de uma imagem cartográfica, devem consideradas como poderosos meios de transferência de mensagens carregadas de ideologias. As decorações, os tipos de letras, os tamanhos dos signos, as cores, os textos dentro dos mapas, todos esses elementos são tão importantes para o processo da comunicação cartográfica, quanto os traçados de ruas, as quadrículas e coordenadas, cotas, e todas as medições que determinam distâncias entre lugares no espaço. Até mesmo o que não está contido nas mensagens do mapa deve ser identificado através de sua ausência. 
Um silenciar cartográfico é uma prática muito ligada à questão das escolhas de quem elabora os mapas e de quem os encomenda. Omitir uma informação "não importante" depende, em grande parte, do interesse de quem comanda o processo de feitura do mapa. De forma semelhante ao segmento da literatura escrita ou da mídia falada, consideramos de suma importância tudo aquilo que é silenciado. A questão dos silêncios nos mapas também é de grande relevância a partir do momento em que os consideramos como veículos de mensagens políticas dissimuladas. Capaz de ser utilizado como filtro ideológico, o silêncio cartográfico tem sido eficiente como modo de discriminação contra os povos nativos, crenças, religiões e culturas. Uma estratégia muito utilizada para destacar áreas em detrimento de outras, fazendo parte também das formas de hierarquização dos lugares e das demarcações espaciais do poder.

Para Monmonier (1991) os mapas mentem no momento em que a verdade é suprimida na intenção de fazer o usuário do mapa ler o que precisa ser lido. Segundo este autor um erro se diferencia de uma mentira, pois o erro é uma falha relativa à capacidade técnica do mapeador, enquanto a mentira diz respeito à seleção daquilo que deve ou não ser dito sobre o espaço de acordo com as intenções.

Para Harley (2005, p. 114), o silêncio deve ser considerado não como ausência de informação, mas como declarações ativas dentro do processo da comunicação das informações sobre o espaço. Há três aspectos que caracterizam a presença de um silêncio em um mapa: a ignorância (quando o cartógrafo registra a sua ignorância por meio de um vazio), o espaço negativo (que expressa por meio de um vazio aquilo o que não é) e o ocultamento intencional (omissão da informação).

Portanto, consideramos também interessante destacar alguns silêncios identificados nos mapas turísticos da cidade. Antes de tudo, queremos afirmar que os mapas turísticos são mapas temáticos e que, portanto, apenas expressam o que de mais relevante existe para o turista. Logicamente muita coisa tem que ser deixada de fora destes mapas, assim como acontece com outros tipos de mapas com temáticas específicas. No entanto, mesmo tendo consciência dessa seletividade dos elementos que devem constar nos mapas turísticos, alguns descuidos e contradições podem ser identificados, como por exemplo, o fato de quase $100 \%$ dos mapas terem "esquecido" de citar uma determinada área de muita importância histórica e econômica para João Pessoa. Deste modo, queremos destacar três silêncios que mais consideramos relevantes para o conjunto dos mapas. 
O primeiro diz respeito a dois símbolos de relevância religiosa na cidade, a Igreja da Penha, localizada na praia de mesmo nome e vizinha ao Farol do Cabo Branco e a Praça de Iemanjá, localizada bem no início da ladeira que dá acesso ao referido Farol. Os dois lugares estão relacionados a dois eventos religiosos de grande porte: a Procissão da Penha - ligada a religião católica e a Festa de Iemanjá - ligada às religiões de origens africanas.

Os dois eventos fazem parte de um calendário permanente na cidade e acontecem um uma vez por ano, atraindo uma grande quantidade de pessoas. No entanto, existe um silenciar no contexto dos mapas que quase apaga a Praça de Iemanjá das imagens dos mapas, ao contrário do que ocorre com a Igreja da Penha. Verificamos que em poucos exemplares de mapas existe a representação da referida praça. Dos 67 mapas considerados (excetuando-se 16 mapas que não abrangem a área de localização da igreja e da praça), 51 mapas representam a Igreja da Penha, desses em apenas 18 aparece a Praça de Iemanjá. O apagamento parcial da informação, neste caso, indica a presença de um filtro ideológico no sentido de ofuscar a grandiosidade e a importância que a Festa de Iemanjá vem tomando desde o seu início em 1965. A mensagem dos mapas, neste caso, deixou claro que o poder simbólico mais relevante é o da igreja católica, que possui a mais alta patente da hierarquia das representações simbólicas nesses mapas. Essas declarações ditas através de silêncios têm a intenção de prolongar, preservar e desenvolver as "verdades" estabelecidas de valores religiosos já fortemente enraizados. Os silêncios são responsáveis também por uma espécie de "ênfase ao contrário" a través de uma seleção de informações que devem ser ocultadas ou evitadas.

Os silêncios toponímicos são um tipo de silêncio que tem relação estreita com o espaço. A nomeação de lugares indica o poder que o nomeador tem sobre o espaço. No nível simbólico este fato é muito importante e serve de atestado para confirmar a posse real ou simbólica de determinado espaço. De maneira contrária, o esvaziamento toponímico do espaço de um mapa elimina simbolicamente aquele lugar, pois, se o lugar não está no mapa, é como se ele não existisse.

O segundo silêncio identificado na cartografia analisada foi o silêncio toponímico referente ao bairro de São José. Este bairro, mesmo estando localizado numa área contígua ao principal Shopping da cidade, o Manaíra, e sendo vizinho do bairro de mesmo 
nome, considerado um dos bairros com população de maior poder aquisitivo ${ }^{28}$ da cidade, é simplesmente ignorado pelos mapas turísticos ao longo do tempo. Este silêncio se verifica mesmo nos mapas recentes, como o mapa 14 que foi produzido em 2011.

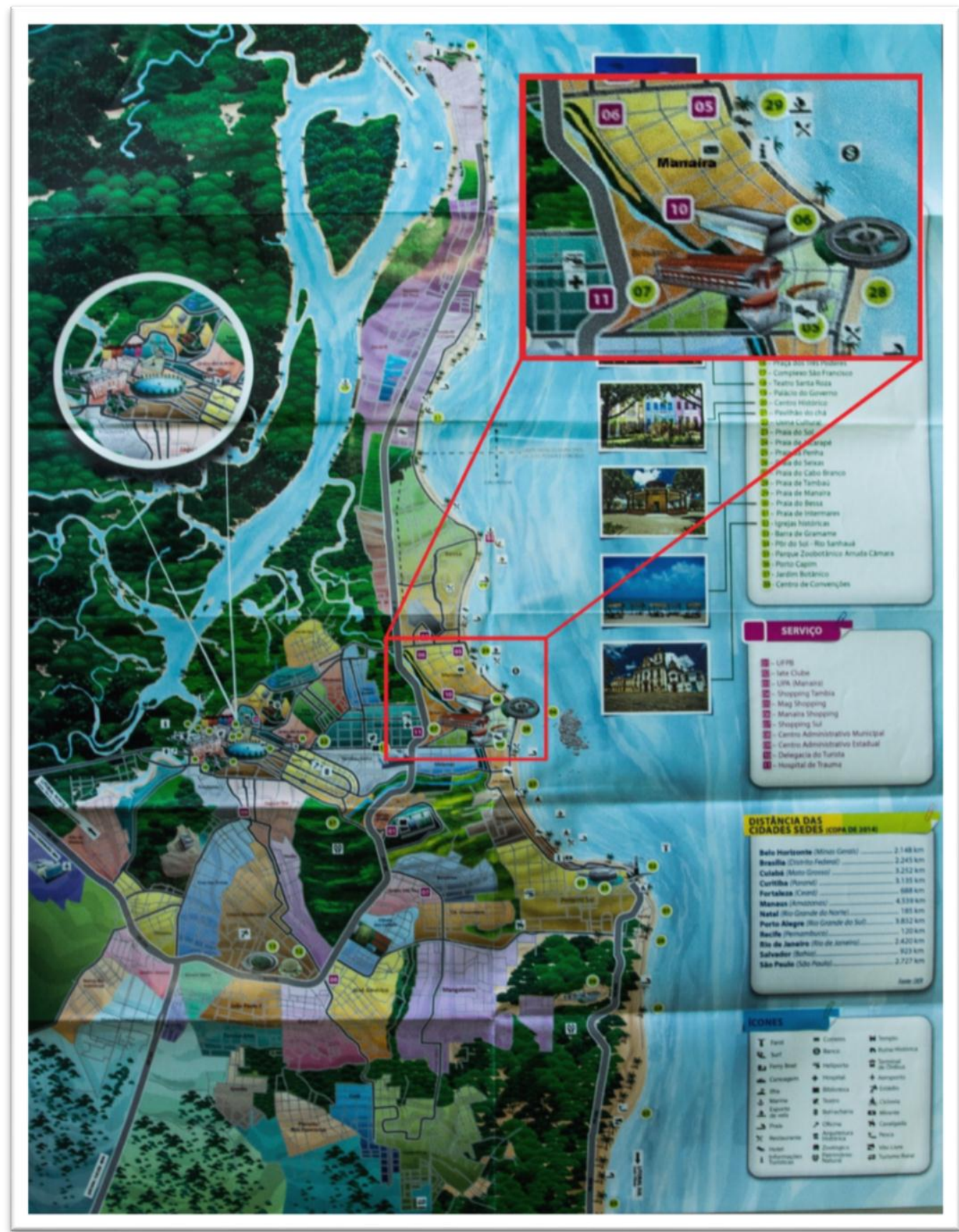

Mapa 14 - Mapa turístico de João Pessoa do ano de 2011. No mapa original consta a área da Lagoa em destaque no círculo branco. No retângulo vermelho destacamos a área referente aos dois bairros citados, com a ausência da toponímia do São José.

\footnotetext{
${ }^{28}$ Topografia Social de João Pessoa (SPOSATI, 2009).
} 
Neste caso, a continuidade deste silêncio toponímico talvez indique a negação do reconhecimento recente feito pela Prefeitura Municipal, que considerou a antiga comunidade São José (que foi resultado de uma ocupação irregular da margem direita do rio Jaguaribe) como um bairro legalizado. Este discurso não está posto nos mapas de uma forma explícita, mas com uma análise mais cuidadosa fica evidente que, em todos os mapas, verificamos a supressão total da toponímia do bairro de São José.

É importante ressaltar que o contexto de formação das ocupações irregulares na cidade de João Pessoa resulta de um complexo processo de crescimento da cidade. Enquanto uma parte da cidade cresce incentivada pelas ações do governo e pelo mercado imobiliário especulativo, outra parte se forma pela via da irregularidade, ilegalidade e carência de condições básicas de infraestrutura. Esta é a realidade de parte da população da cidade moradora da periferia ou de áreas de vales de rios, encostas e leitos de manguezais (como é o caso do São José), aonde quase nunca chegam melhorias de infraestrutura, equipamentos e serviços urbanos.

O fato do não registro do nome do bairro de São José nos mapas se configura como um ato de segregação, tanto econômica, quanto social. A sua presença contígua ao bairro de Manaíra, classificado como um dos mais bem colocados no índice de inclusão social e econômica (SPOSATI, 2009), torna-se um incômodo que, pelo menos nos mapas, é possível de eliminar. A tendência da cartografia turística da cidade de João Pessoa tem sido a de tentar erradicar a geografia da pobreza e de todos os incômodos possíveis, sejam eles sociais, econômicos ou ambientais.

O terceiro silêncio se refere ao exemplo de Bayeux, cidade que faz conurbação com João Pessoa no sentido oeste. Esta cidade faz parte da Região Metropolitana e é caminho de passagem obrigatória ${ }^{29}$ para a maioria dos destinos turísticos vinculados aos pacotes que incluem João Pessoa, pois abriga o aeroporto Castro Pinto e é cortada por duas importantes rodovias federais a BR 230 e a BR 101.

A situação da presença da toponímia desse município nos mapas turísticos é intrigante, pois apenas três mapas fazem discretas alusões à cidade de Bayeux através da indicação de sua toponímia, sendo que apenas um mapa faz a representação espacial da

\footnotetext{
${ }^{29}$ Até o ano de 1990 este município consistia de passagem quase obrigatória por ser o principal acesso de quem chegava à cidade de João Pessoa vindo do interior (MARTINS JÚNIOR, 2006).
} 
cidade através de símbolos que identificam a presença de área habitada. Na maioria dos mapas o seu sítio urbano é representado por um vazio, algumas vezes preenchido pela representação de uma vegetação mais densa do que a das outras áreas. Outras estratégias de silenciamento mais intensas são utilizadas em alguns mapas, pois não basta apenas deixar o espaço vazio, é necessário que ele seja ocupado com qualquer outro tipo de informação, para não dar nenhuma margem a uma possível identificação do lugar.

Esta estratégia foi utilizada em alguns mapas, como vemos no mapa 15 que tenta negar a existência daquela cidade colocando placas enormes indicando os sentidos de vários outros municípios exatamente no lugar onde deveria estar a representação simbólica de Bayeux.

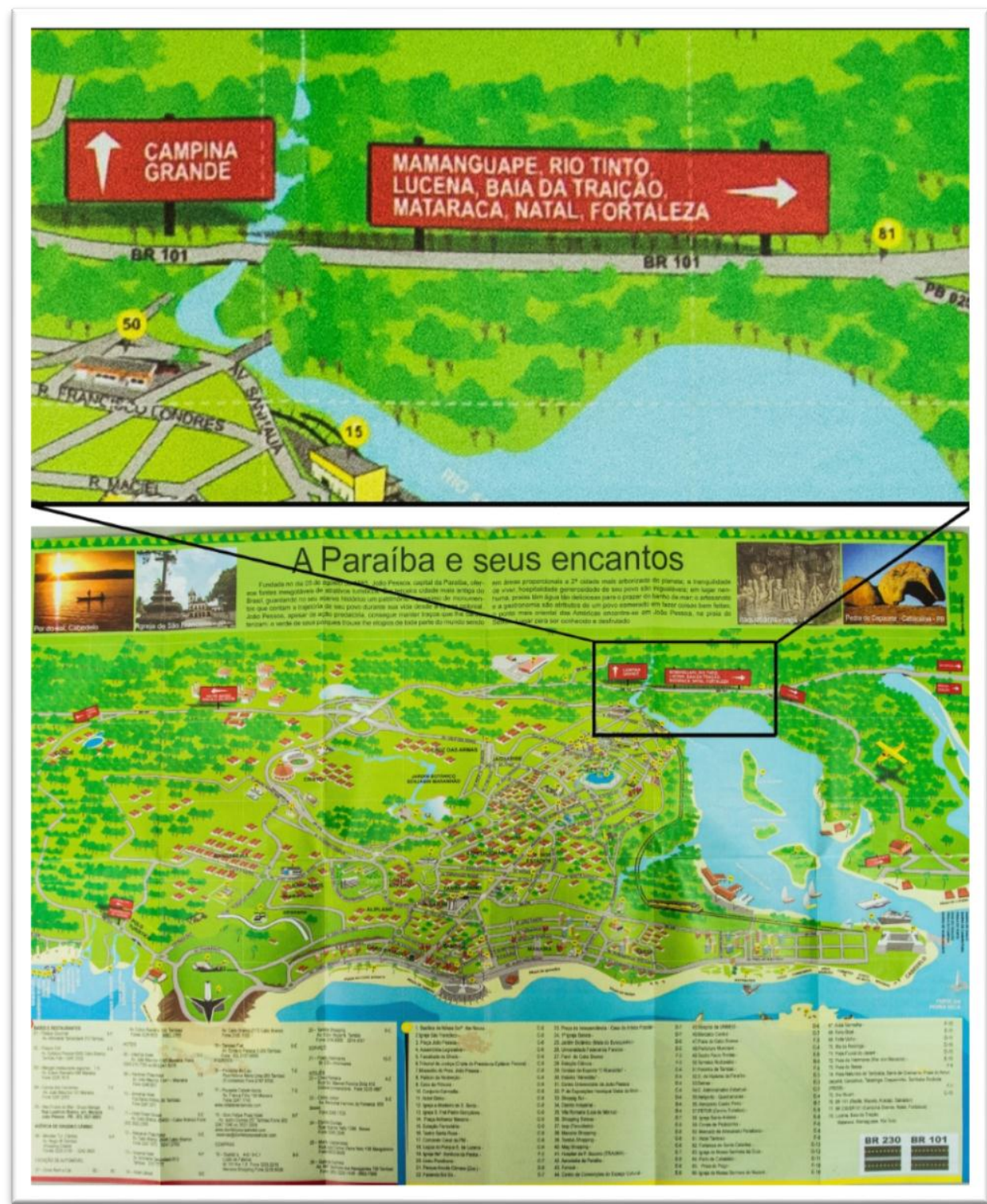

Mapa 15 - Mapa turístico de João Pessoa com detalhe da área do município de Bayeux ocupada por sinalização turística. Data: 2011. 
A exclusão de Bayeux da cartografia turística da cidade se configura num ato deliberado de apagamento de uma população inteira. Um silenciar que evidencia uma luta tácita pela ocupação e posse do poder simbólico da cidade dos mapas turísticos. Uma luta que tem sido fundamentada através das percepções das diferenças de classe e de origens étnicas das populações locais.

Vale ressaltar que o processo da formação inicial de Bayeux se deu historicamente pela ocupação de suas terras por trabalhadores, primeiramente por pescadores e trabalhadores da estiva do Porto do Capim quando do seu auge econômico e, em seguida, pelos trabalhadores já ligados à produção industrial (MARTINS JÚNIOR, 2006). A escolha de parte de sua área, em 1941, para a construção do leprosário do Estado (época em que a lepra era considerada uma doença contagiosa e necessitava de um espaço externo e afastado da população) é outro indício que atesta os preconceitos ocultos e externalizados sutilmente pelas práticas sociais, como por exemplo, na negação de seu espaço nos mapas.

Ao turismo interessa um espaço cuja imagem seja símbolo de modernidade e beleza. Aos mapas cabe trabalhar a imagem de João Pessoa como cidade turística, através do realce dos pontos positivos e da negação das contradições de ordem social através de estratégias como o silêncio cartográfico. O silenciamento de bairros e/ou cidades inteiras é uma forma de negar a pobreza existente na cidade, pois não se mostram os aspectos incômodos de um espaço que se quer vender. Afinal não há simbologia simpática que represente a pobreza, ou a realidade da classe trabalhadora na sua luta diária. 


\section{Conclusões}

\section{Em tempo, reflexões acerca do fato apreendido}

Porto do Capim ${ }^{30}$

a cidade de joão pessoa nunca olha de frente para o rio sanhauá talvez por ter vergonha das suas margens a cidade não veste a pele dos que encharcam os pés nas beiradas do porto do capim

onde as chuvas aniquilam o pouco dos que pouco possuem

onde os barcos atracam no assoreamento e no abandono

onde um estupro urbanístico é prometido pelos que mandam e fazem

pelos que arrancam as árvores porque acreditam não precisar dos pássaros

a cidade de joão pessoa esqueceu do seu nascedouro

virou as costas para onde a verdade maior é o reflexo da lua nas águas do rio

um lugar onde o esquecimento solidifica o barro no tempo e a beleza é o alimento de cada manhã

suas mulheres transformaram a luta num lugar de morada

(Lau Siqueira)

Como disse Latour (2000) no fazer científico comumente conteúdo, contexto, pesquisador, pesquisa se confundem. Na metáfora de Latour a pesquisa seria um sistema complexo, uma espécie de caixa preta de Pandora a respeito da qual nada interessa ou é necessário saber a não ser o que nela entra e o que dela sai. Para o autor a ciência teria dessas contradições, semelhante às duas faces de Jano, a ciência em muitos momentos,

${ }^{30}$ Poema dedicado às mulheres da comunidade do Porto do Capim, localizada no bairro do Varadouro em João Pessoa, que resistem com garra aos desejos ilimitados da especulação capitalismo. 
diz ao mesmo tempo coisas completamente diferentes. Ele afirma que, muitas vezes, olhando-se bem nas caixas pretas pode-se ler o aviso, "Perigo: não abra", e ver que "paixões, prazos finais e decisões são coisas que escapam por todos os lados da caixa que permanece aberta.

Tecer os fios de uma pesquisa e conseguir materializá-la numa síntese é um trabalho árduo onde, apesar do esforço para a sua efetivação, frequentemente alguns pontos ficam soltos ou muita coisa pode deixar de ser dita.

Lefebvre (1969) já afirmava que a combinação de elementos separados não é nunca uma síntese. Que não se recompõe uma cidade a partir de seus signos, pois ela não se restringe a uma linguagem. Mais que uma linguagem, a cidade seria uma prática e ninguém estaria habilitado a pronunciá-la ou anunciá-la como uma síntese.

O trabalho aqui em questão abordou o discurso expresso nos mapas turísticos acerca dos espaços de interesse para o turismo da cidade de João Pessoa. O foco foi direcionado para a percepção de como a cartografia turística que tem sido produzida para a cidade tem expressado a história da construção de um espaço-mercadoria destinado ao consumo pelo turismo.

Para compreender a constituição do caráter urbano de João Pessoa consideramos importante tomar como ponto de partida a história de sua formação urbana. Buscamos compreender, em bases gerais, as características de seu desenvolvimento dentro do quadro geral das cidades do Nordeste e como a cidade hoje se configura dentro do contexto turístico atual.

A opção em tomar a via histórica teve como base a compreensão de que uma cidade se constitui, inevitavelmente, de relações complexas entre seus diversos elementos, poderes, instituições e sociedade. Como diria Lefebvre (1969), a cidade é mais que uma materialidade apenas, sendo o resultado da mediação entre as suas infraestrutura e superestrutura. Ela seria constituída através de uma história social viabilizada pelas relações de classe e propriedade, cheias de contradições e embates, avanços e recuos no tempo e no espaço, tendo a dinâmica como a sua característica mais autêntica.

A fundação da cidade de Nossa Senhora das Neves, atualmente cidade de João Pessoa, guarda consigo toda essa riqueza de uma história social permeada de lutas e 
contradições. Dentro de um histórico de longos anos de batalhas entre portugueses, índios e franceses pela posse das terras que viriam a ser o Nordeste e o Norte.

Assim, foi sendo inaugurado o seu caráter urbano, em meio à conjuntura da colonização luso-hispânica, foi uma cidade inventada e constituída de acordo com necessidades específicas próprias do contexto da época. Daquele modo, vão aparecendo os contornos do que seriam os primeiros traçados do seu formato urbano, cuja instalação se deu sobre um sítio favorável, tanto para o escoamento de mercadorias, quanto para a sua defesa. Nada muito original que a diferisse, nesse sentido, de diversas outras cidades do Nordeste, a não ser o fato de que ela nasce de olhos voltados para o rio e de costas para o mar. Mar este que só viria a fazer parte do cotidiano da cidade muitos séculos depois.

A ela atribui-se a função primordial de cidade administrativa e, mesmo a Parahyba possuindo uma produção própria e diversificada de mercadorias de grande interesse na época, a sua capital não se desenvolve como um pólo importante de escoamento de produtos. A subordinação financeira e alfandegária com relação à Recife a situou historicamente num lugar periférico dentro do contexto econômico, político e social. Como consequência, a cidade adquire uma monotonia econômica e social que será a tônica a refletir por longo tempo nos seus aspectos urbanos. De tal modo que, mesmo com a chegada do século XIX, caracterizado por mudanças estruturais por todos os segmentos da sociedade ocidental, até meados de 1850 a cidade pouco se expandiu além de seu núcleo urbano original.

A morosidade no seu crescimento e no seu desenvolvimento se manteve como uma marca presente na história de João Pessoa, desde seu lento crescimento urbano e populacional, às precariedades relativas aos serviços básicos de saneamento e iluminação. Os anseios de progresso e higiene, aliados à intenção de tornar a cidade moderna, com a implantação dos serviços básicos de saneamento, iluminação e transporte só foram atendidos nas primeiras décadas do século XX.

$\mathrm{Na}$ cidade as modernizações urbanas acontecem sempre depois que já aconteceram praticamente em todos os lugares. Há um caráter na cidade que pode ser apontado por uma idéia de lentidão, onde tudo demora a ser implementado e, mesmo quando acontece, se faz de forma incompleta. A iluminação à gás, a energia elétrica, a água encanada, os bondes puxados à animais, ou seja, todas as melhorias consideradas 
modernas na virada do século XX, aconteceram em João Pessoa depois de já serem realidade há anos na maioria das outras cidades do país.

Neste caminho, a cidade tem sido, o tempo todo, a expressão de modernizações tardias e incompletas, com a particularidade de que, boa parte do capital investido para a aquisição das melhorias na cidade foi oriundo do capital rural e advindo principalmente das famílias dos antigos senhores de engenho, denominados posteriormente de usineiros.

Podemos afirmar que o capital industrial não esteve presente em praticamente nenhuma das lentas transformações que ocorreram na cidade, onde nunca se pôde falar da presença de uma industrialização. Neste sentido, ela foge a uma regra muito comum, que é a de se considerar o mundo um meio homogêneo, como se, as coisas e os fenômenos ocorressem em todos os lugares da mesma forma e intensidade.

Aqui o fenômeno urbano carece de outra lógica para a análise. Não há como pensar a cidade considerando o quadro sincrônico proposto por Lefebvre (1999), onde as fases rural, industrial e urbana sucedem-se. Afinal, a industrialização aqui não teve um papel marcante na transformação do espaço urbano.

Seguimos por outra via proposta por Lefebvre (1999) evitando as interpretações ideológicas totalizadoras, que acabam por reduzir as características específicas de muitos espaços urbanos, quando os compreendem apenas através da ótica industrial. Por este caminho, a cidade de João Pessoa, considerando as suas especificidades - no que se refere à ausência de industrialização e à manutenção de características rurais e ritmo lento das mudanças - se configura, de acordo com Lefebvre, como um espaço diferencial do urbano.

O que aconteceu foi que, a cidade, mesmo apresentando-se como capital do Estado e estando inserida no contexto do mundo global, ainda vem preservando ao longo dos tempos um caráter de rurbanidade muito marcante, os denominados tempos lentos de que tratou Maia (2000) em sua pesquisa sobre a permanência dos costumes rurais nesta cidade.

Este caráter de rurbanidade ainda presente em João Pessoa, ao mesmo tempo que, sob alguns aspectos, tem atuado como freio para o desenvolvimento do capital local, possibilitou que a cidade se constituísse como uma das últimas fronteiras de um espaço urbano ainda possuidor de características naturais. Desse modo, contraditoriamente, a 
cidade não só é a expressão desse lugar do atraso, mas a possibilidade de um capital de realização futura na forma de raridades cada vez mais valorizadas.

O modelo adotado para a produção do espaço urbano-turístico de João Pessoa parece ter sido o da "não produção" de seu espaço. Ou seja, a lógica seria a de interferir o mínimo possível em parte do espaço, usando para isso barreiras legais como leis estaduais elou municipais que restrinjam a ocupação e o uso do solo para fins diferentes daqueles permitidos.

Deste modo, além da lentidão das mudanças urbanas, a seletividade espacial foi sendo uma conseqüência desta forma de produzir o espaço da cidade. A década de 1970 foi marcante neste sentido, pois delimita o início do aumento da política de habitação popular do Governo Federal que, aqui em João Pessoa, impeliu as populações mais pobres para áreas cada vez mais distantes da orla marítima, ao mesmo tempo em que financiamentos de casas de padrão mais alto eram oferecidos em bairros próximos da praia e da avenida Epitácio Pessoa.

No entanto, a produção desse espaço da cidade não se verificou apenas na dimensão do concreto, onde a cidade torna-se um fato material palpável. Essa produção também foi trabalhada e realizada no campo das representações e das idéias através de construções simbólicas desse espaço. A cidade passa a ser moldada para o turismo, tornase espetáculo e, como afirma Debord (1997), o espetáculo é a ideologia por excelência.

A promoção dessa cidade espetáculo através de discursos se tornou um dos modos de venda de seu espaço turístico, tendo nos mapas turísticos importantes veículos de transmissão dessas mensagens. O discurso geográfico, o discurso da cidade natureza e o da cidade histórica, atribuem à cidade aspectos de raridades e diferenciações que a torna um destino procurado e valorizado.

Outros discursos foram identificados sob a forma de símbolos materiais ou ícones que demarcam a presença do poder estabelecido, como o Hotel Tambaú e a Lagoa que são frequentemente representados nos mapas numa hierarquia visual bem favorável.

A cidade negada ou silenciada também faz parte desse discurso, a partir do momento em que essa ausência da informação torna-se uma declaração ativa. O caso da cidade de Bayeux e do bairro de São José evidencia um discurso da negação ou da 
omissão da informação, pois são informações sobre o espaço que não somam positivamente na contabilidade da sua valorização.

Assim, sob a forma de mercadoria, produz-se um simulacro da cidade, onde ela perde qualquer vestígio de sua personalidade autêntica. Essas representações terminam por criar uma "pseudo cidade" produzida sob encomenda para o consumo, que precisa, repetidamente, reafirmar o seu caráter através de discursos, que devem ser frequentemente pronunciados para não perder o seu sentido nem a sua veracidade.

Essa é a João Pessoa que tem sido expressa na sua cartografia turística. Uma cidade espetáculo criada para o consumo, que nega a si própria, abrindo mão de sua autenticidade para se tornar uma imitação de si mesma. Essa é a cidade dos mapas turísticos muito bem definida nas palavras de Debord (1997), as quais transcrevo abaixo:

O urbanismo que destrói as cidades, reconstrói um pseudocampo, no qual estão perdidas tanto as relações naturais do antigo campo como as relações sociais diretas da cidade histórica, diretamente postas em questão. É um novo campesinato fictício, recriado pelas condições de habitat e de controle espetacular no atual "território ordenado": a dispersão no espaço e a mentalidade acanhada, que sempre impediram o campesinato de empreender uma ação independente e de se afirmar como potência histórica criadora, retornando à condição de produtores -- o movimento de um mundo que eles próprios fabricam, ficando tão completamente fora do seu alcance como quanto o ritmo natural dos trabalhos para a sociedade agrária. Mas este campesinato, outrora a inabalável base do "despotismo oriental", cujo próprio estilhaçamento provocou a centralização burocrática, reaparece como resultado das condições de aumento da burocratizarão estatal moderna, a sua apatia teve de ser agora historicamente fabricada e alimentada; a ignorância natural cedeu o lugar ao espetáculo organizado do erro. As "cidades novas" do pseudocampesinato tecnológico inscrevem claramente a ruptura com o tempo histórico sobre o qual são construídas; seu lema bem que podia ser: "Aqui não aconteceu nada, nem nunca acontecerá". Porque a história da necessidade de libertar as cidades ainda não foi desencadeada. As forças da ausência histórica começam a compor a sua própria e exclusiva paisagem (DEBORD, 1997, p. 137).

A exemplo de Debord e, para além dele, quiçá pudéssemos dizer que muitas coisas acontecem na cidade plasmadas em seus mapas que anunciam a mercadoria turística. Uma cidade para os outros, mas, sobretudo, para o capital, que no processo de universalização 
encontra suas singularidades. Ali, onde a diferença aparente dos fenômenos é parte da totalidade dos processos, dando, às vezes, no próprio espetáculo, essa impressão de que nada aconteceu e de que nada acontecerá. Os ritmos lentos da cidade encontram a velocidade brutal dos processos de apropriação capitalista dos espaços históricos e da natureza.

Olhar a cidade em que se habita a partir dos seus mapas turísticos é como ver a vitrine onde ela é disposta à venda. O fio com que se tece uma tese é parte desse labirinto de possibilidades onde se misturam, se confundem (como já dissera Latour sobre o fazer científico), comumente conteúdo, contexto, pesquisador e pesquisa 


\section{REFERÊNCIAS BIBLIOGRÁFICAS}

AGUIAR, Wellington Hermes Vasconcelos de. A velha Paraíba nas páginas de jornais. João Pessoa: A União, 1999.

AGUIAR, Wellington Hermes Vasconcelos de. Cidade de João Pessoa: a memória do tempo. João Pessoa: GRAFSET, 1993.

AGUIAR, Wellington Hermes Vasconcelos de; MELLO, José Octavio de Arruda. Uma cidade de quatro séculos: evolução e roteiro. João Pessoa: FUNCEP, 1989.

ALMEIDA, Horácio de. História da Paraíba. João Pessoa: Editora Universitária/UFPB, 1997.

ALMEIDA, José Américo de. Cidade de João Pessoa: roteiro de ontem e hoje. João Pessoa: Gráfica Santa Marta, 2005.

ALMEIDA, Maria Cecília Fernandes de. Espaços públicos em João Pessoa (1889 1940): formas, usos e nomes. 2006. 255 f. Dissertação (Mestrado em Arquitetura e Urbanismo) - Universidade de São Paulo, PPGAU/Escola de Engenharia de São Carlos. São Carlos, SP, 2006

BARBOSA, Adauto Gomes. Produção do espaço e transformações urbanas no litoral sul de João Pessoa-PB. 2005. Dissertação (Mestrado em Geografia) - Universidade Federal do Rio Grande do Norte, DGeo-PPGe, Natal, 2005.

BARBOSA, Adauto Gomes. Turismo e produção do espaço litorâneo: Modernização e contradições socioespaciais Em João Pessoa - PB. Cadernos do Logepa v. 6, n. 1, p. 58 75, jan./jun. 2011.

BARTHES, Roland. O neutro. São Paulo: Martins Fontes, 2003.

BECKER, Bertha. Políticas e planejamento do turismo no Brasil. In: YÁZIGI, Eduardo; CARLOS, Ana Fani Alessandri; CRUZ, Rita de Cássia Ariza da. Turismo: espaço, paisagem e cultura. São Paulo: Hucitec, 2002, p. 181-192.

BRASIL, Ministério do Turismo. Plano Aquarela: marketing turístico internacional do Brasil - 2007 - 2010. Brasília: Ministério do Turismo, 2007. Disponível em:

<www.turismo.gov.br/export/sites/default/turismo/o_ministerio/publicacoes/downloads _publicacoes/Plano_Aquarela_2007_a_2010.pdf>.>. Acesso em: 1 mai. 2014.

BRASIL. Ministério do Turismo. Caracterização e dimensionamento do turismo doméstico no Brasil - 2010/2011. Relatório executivo - produto 6. Brasília: Ministério do Turismo, 2012.

BRASIL. Ministério do Turismo. Embratur. Dados e fatos: estudos, pesquisas e dados sobre o setor de turismo. Brasília: Ministério do Turismo/Embratur, 2014. Disponível em: $<$ WWW.dadosefatos.turismo.gov.br/export/sites/default/dadosefatos/estatisticas_indica dores/receita_cambial/downloads_receita/Receita_e_Despesa_Turxstica_Cambial__Serie_Histxrica_-_Ano_Mes_-_1990-Mar2014.pdf> Acesso em: 27 jun. 2014. 
BRASIL. Ministério do Turismo. Fundação Getulio Vargas. Boletim de Desempenho Econômico do Turismo. Ano XI, n. 41, jan. 2014. Rio de Janeiro: FGV/ Ministério do Turismo, 2014.

BRASIL. Ministério do Turismo. Plano Nacional do Turismo 2013 - 2016. Brasília: Ministério do Turismo, 2013. Disponível em: <WWW.turismo.gov.br/turismo/o_ministerio/publicacoes/cadernos_publicacoes/03plan os_nacionais.html>. Acesso em: 27 jun. 2014.

CARVALHO, Caio Luiz de. Políticas públicas no turismo brasileiro: a cidade de São Paulo e a construção de sua identidade turística. Tese (Doutorado). Universidade de São Paulo, São Paulo, 2009.

CAZES, George. Turismo e subdesenvolvimento: tendências recentes. In: RODRIGUES, Adyr Balastreri (org.). Turismo e Geografia: reflexões teóricas e enfoques regionais. São Paulo: HUCITEC, 2001.

CHAGAS, Waldeci Ferreira. As singularidades da modernização na Cidade da Parahyba, nas décadas de 1910 a 1930. 2004. 281 f. Tese (Doutorado em História)Universidade Federal de Pernambuco, Recife, 2004.

CHAGAS, Waldeci Ferreira. Um novo olhar sobre a Parahyba. SHCU, 1990, Seminário de História da Cidade e do Urbanismo. v. 6, n. 1, 2000. Disponível em: <www.anpur.org.br/revista/rbeur/index.php/shcu/issue/view/44>. Acesso em: 21 set. 2013.

COELHO, Margarida Hatem Pinto. Ocupação do setor de turismo no Brasil: análise da ocupação nas principais ACTs. Brasília: IPEA, 2011.

CORTESÃO, Jaime. História do Brasil nos velhos mapas. Tomo I. Lisboa: Imprensa Nacional - Casa da Moeda, 2009. 469p.

COUTINHO, Marco Antônio Farias. Evolução urbana e qualidade de vida: o caso da Avenida Epitácio Pessoa. 2004. 220 f. Dissertação (Mestrado em desenvolvimento e meio ambiente. PRODEMA) - Universidade Federal da Paraíba, João Pessoa, 2004.

CRAMPTON, Jeremy; W; KRYGIER, John. An Introduction to Critical Cartography. ACME: An International E-Journal for Critical Geographies, v. 4, n. 1, p. 11 - 33, 2006. Disponível em: http://www.acme-journal.org/vol4/JWCJK.pdf.

CRUZ, Rita de Cássia Ariza da. "Patrimonialização do patrimônio": ensaio sobre a relação entre o turismo, "patrimônio cultural" e produção do espaço. In. GEOUSP Espaço e Tempo, São Paulo, n. 31, p. 95 - 104, 2012.

CRUZ, Rita de Cássia Ariza da. Introdução à geografia do turismo. São Paulo: Roca, 2003. $125 \mathrm{p}$.

CRUZ, Rita de Cássia Ariza da. Megaprojetos do Nordeste: reflexões acerca de um modelo internacional de urbanização turística do litoral. In, Encontro Regional de Estudos Geográficos, 6., 1997, João Pewssoa/Recife. Anais... João Pessoa/Recife: Associação dos Geógrafos Brasileiros, 1997. 
CRUZ, Rita de Cássia Ariza da. Planejamento governamental do turismo: convergências e contradições na produção do espaço. In: América Latina: cidade, campo e turismo. São Paulo: 2006. Disponível em: WWW.bibliotecavitual.clacso.org.ar/ar/libros/edicion/lemos/19cruz.pdf. Acesso em 11 out. 2013.

CRUZ, Rita de Cássia Ariza da. Políticas públicas de turismo no Brasil: território usado, território negligenciado. In. Geosul, Florianópolis, v. 20, n. 40, p. 27-43, jul./dez. 2005.

DEBORD, Guy. A sociedade do espetáculo. Rio de Janeiro: Contraponto, 1997.

FERNANDES, Ocione do Nascimento. A produção e a comercialização de mercadorias no Brejo da Parahyba do Norte (1793 - 1883). - João Pessoa, 2008. 116p. Dissertação (mestrado) UFPB/CCEN.

FOUCAULT, Michel. Arqueologia do Saber. Rio de Janeiro: Forense Universitária, 2005.

FOUCAULT, Michel. As palavras e as coisas. Lisboa: Portugália, 1967.

GINZBURG, Carlo. Os Andarilhos do Bem. São Paulo: Cia das Letras, 1988.

GODOY, Paulo R. T. de; BRAY, Silvio C. Considerações sobre o espaço urbano no Brasil. In: GERARDI, Lucia Helena (org.). Ambientes: Estudos Geográficos. Rio Claro: Programa de Pós-Graduação em Geografia - UNESP - Associação de Geografia Teorética - AGETEO, 2003. p. 185-200. Disponível em: <http://www.rc.unesp.br/igce/geografia/pos/downloads/2003/livro_completo.pdf>.

Acesso em 17 dez. 2013.

GOMES, Maria do Carmo Andrade. Velhos mapas, novas leituras: revisitando a história da cartografia. In. GEOUSP - Espaço e Tempo, São Paulo, n. 16, p. 67 - 79, 2004.

GONÇALVES, Regina Célia. "Guerras e Açúcares: a formação da elite política na Capitania da Parayba (séculos XVI e XVII)". In: OLIVEIRA, Carla Mary da Silva; MEDEIROS, Ricardo Pinto de. Novos Olhares sobre as Capitanias do Norte do Estado do Brasil. João Pessoa: UFPB, 2007. p. 23-65.

GONÇALVES, Regina Célia. Guerras e Açúcares: política e economia na Capitania da Parayba (1585-1630). Bauru: Edusc, 2007, 329 p.

HARLEY. J. Brian. La nueva naturaleza de los mapas. Ensayos sobre La historia de La cartografia. Mexico: Fondo de Cultura Económica, 2005. 398 p.

HARLEY. J. Brian. Un cambio de perspectiva. EI Correo de la Unesco. Paris, n. 6, p. $10-15,1991$.

HARVEY, David. A produção capitalista do espaço. São Paulo: Annablume, 2005. 252 p.

HOLANDA, Sérgio Buarque de. (et al). História Geral da Civilização Brasileira. vol. 1. $8^{a}$ ed. Rio de Janeiro: Bertrand Brasil, 1989. 
IBGE. Instituto Brasileiro de Geografia e Estatística. Economia do turismo: Análise das atividades características do turismo 2003. Disponível em: <www.ibge.gov.br/home/estatistica/economia/industria/economia_turismo/comentarios. pdf $>$. Acesso em: 7 de nov. 2014.

IFEP - Instituto Fecomércio de Pesquisas Econômicas e Sociais da Paraíba. Pesquisa anual do desempenho do turismo na Região Metropolitana de João Pessoa. João Pessoa: IFEP, 2014.

IHGP. Anais do Ciclo de Debates sobre a Paraíba na Participação dos 500 anos de Brasil. João Pessoa: Secretaria de Educação e Cultura do Estado, 2000. 414p. Capítulo: a Paraíba e a primeira República. Disponível em: <www.ihgp.net/pb500f.htm> .

KANTOR, Iris. Cartografia e diplomacia: usos geopolíticos da informação toponímica (1750-1850). Anais do Museu Paulista. São Paulo, v.17. n. 2. p. 39-61 jul/dez. 2009.

LACOSTE, Yves. Geografia: isso serve, em primeiro lugar, para fazer a guerra. Campinas, SP: Papirus, 1993.

LAFUENTE, Antonio. La ciencia periférica y su especialidad historiográfica. In: SALDAÑA, Juan José (editor). Actas del Simposio - Historia y Filosofia en la Ciencia en America do XI Congreso Interamericano de Filosofía, Cuadernos de Quipu, Guadalajara, n. 01, p. 31-40, 1986.

LATOUR, Bruno. Ciência em ação: como seguir cientistas e engenheiros sociedade afora. São Paulo: UNESP, 2000.

LAVIERI, João Roberto; LAVIERI, Maria Beatriz Ferreira. Evolução da estrutura urbana recente de João Pessoa - 1960/1986. Textos UFPB/NDIHR, n. 29, jul. 1992.

LE GOFF, Jacques. História e memória. Campinas: Editora da UNICAMP, 2003.

LEAL, Wills. O real e o virtual no turismo da Paraíba: a História do Turismo Paraibano. João Pessoa: Arpoador, 2001.

LEANDRO, Aldo Gomes. A orla marítima de João Pessoa: da apropriação urbana à (re)apropriação turística. $6^{\circ}$ Encontro dos Geógrafos da América Latina. Buenos Aires, 1997. 01 cd-rom.

LEANDRO, Aldo Gomes. O turismo em João Pessoa e a construção da imagen da cidade. 2006. Dissertação (Mestrado em Geografia) - UFPB/CCEN, Universidade Federal da Paraíba, João Pessoa, 2006.

LEFEBVRE, Henri. A revolução urbana. Belo Horizonte: UFMG, 1999. 178 p.

LEFEBVRE, Henri. O direito à cidade. São Paulo: Documentos, 1969.

LEITÃO, Deusdedit de Vasconcelos. Ruas de Tambaú. João Pessoa: DPGISecretaria da Educação e Cultura, 1998. 51p. 
LINHARES, Maria Yedda. História Geral do Brasil. Rio de Janeiro: Elsevier, 2000. Lisboa, 2 a 5 de Nov. 2005. FCSH/UNL. Disponível em: < http://cvc.institutocamoes.pt/eaar/coloquio/comunicacoes/serioja_cordeiro_mariano.pdf $>$. Acesso em: 25 nov. 2013.

LUCHIARI, Maria Tereza Duarte Paes. A reinvenção do patrimônio arquitetônico no consumo das cidades. In. Geousp. Espaço e tempo, São Paulo, n. 17, p. 95-105, 2005.

MADRUGA, Antônio Moacyr. Litoralização: da fantasia de liberdade à modernidade autofágica. 1992. Dissertação (Mestrado em Geografia) - Universidade de São Paulo, 1992.

MAIA, Doralice Sátyro. Notas sobre o crescimento de João Pessoa. Revista Conhecendo a Paraíba. Ano 1. n. 1. João Pessoa: UFPB/LOGEPA, 2002.

MAIA, Doralice Sátyro. Tempos lentos na cidade: permanências e transformações dos costumes rurais na cidade de João Pessoa - PB. 2000. Tese (Doutorado em Geografia) Faculdade de Filosofia, Letras e Ciências Humanas, Universidade de São Paulo, São Paulo, 2000.

MARCELLINO, Nelson Carvalho. Estudos do Lazer - uma introdução, Campinas: Autores Associados, 1996. 99 p.

MARIANO, Serioja Rodrigues Cordeiro; MARIANO, Nayana R. C. O medo anunciado: a febre amarela e o cólera na província da paraíba (1850-1860). Revista de Historia e Estudos Culturais. Set. out. nov, dez 2012. Vol. 9, ano IX, n. 3. Disponível em:<www.revistafenix.pro.br/pdf30/dossie_artigo_5_serioja_rodrigues_cordeiro_mariano_e_n ayana_r_c_mariano_fenix_set_out_nov_dez_2012.pdf $>$. acesso em 25 nov. 2013.

MARIANO. Serioja Rodrigues Cordeiro. Família e Relações de Poder na Capitania da Paraíba: O Governo de Jerônimo de Melo e Castro (1764 a 1797). In Actas do Congresso Internacional Espaço Atlântico de Antigo Regime: poderes e sociedades, Lisboa, 2005 .

MARQUES, Amanda Christinne Nascimento. Território de Memória e Territorialidades da Vitória dos Potiguara da aldeia Três Rios/ Amanda Marques João Pessoa, 2009. 217f. : il. Dissertação (Mestrado) - UFPB/ CCEN/ PPGG

MARTINS JÚNIOR, Everaldo Virgínio. O processo de ocupação e as questões sociais no bairro de São Bento em Bayeux - PB. 2006. 130 f. Dissertação (Mestrado em Geografia) - UFPB/CCEN, Universidade Federal da Paraíba, João Pessoa, 2006.

MARTINS, Dayse Luckwü. A paisagem da antiga Paraíba através dos mapas. In: 1 Simpósio Brasileiro de Cartografia Histórica, Paraty, 10 a 13 de maio de 2011.

MEDEIROS, Coriolano de. O Tambiá da minha infância. João Pessoa: A União, 1994.

MELLO, José Octávio de Arruda (org). Capítulos de história da Paraíba. João Pessoa: O NORTE, 1987. 
MELLO, José Octávio de Arruda. Capítulos de História da Paraíba. Campina Grande: Grafset, 1978.

MELLO, José Octávio de Arruda. História da Paraíba: lutas e resistências. João Pessoa: Ed. Universitária/UFPB, 1995.

MELLO, José Octávio de Arruda; COSTA, Iveraldo Lucena da. A Paraíba no século XX: oligarquias, açudagem e resistência. João Pessoa : Fundação Ulisses Guimarães, 2002.

MONMONIER, Mark. How to lie with maps. Chicago and London: The University of Chicago Press, 1991.

MOONEN, Frans; MAIA, Luciano Mariz Maia. (orgs). História dos índios Potiguara: 1500 - 1983 (Relatórios e Documentos). 2a ed. Digital. Recife: 2008.

MORAES, Antonio Carlos Robert de; COSTA, Wanderley Messias da. A valorização do espaço. São Paulo: HUCITEC, 1987.

MORAES, Antonio Carlos Robert de. Bases da formação territorial do Brasil. Geografares. n. 2. Vitória, jun. 2001.

MORAES, Antônio Carlos Robert. Bases da formação territorial do Brasil: o território colonial brasileiro no "longo" século XVI. São Paulo: Hucitec, 2000.

MORAES, Antonio Carlos Robert. Contribuições para a gestão da zona costeira do Brasil: elementos para uma geografia do litoral brasileiro. São Paulo: Annablume, 2007.

MOREIRA, Raphaela Cristhina Claudino. A questão do gabarito na orla marítima de João Pessoa (bairro de Manaíra, Tambaú e do Cabo Branco). 2006. 125 p. Dissertação (Mestrado em Engenharia Urbana) - Universidade Federal da Paraíba, João Pessoa, 2006.

NOGUEIRA, Helena de Cássia. As primeiras décadas da eletricidade e do saneamento básico na capital paraibana, 1900 - 1940. 2005. 111 f. Dissertação (Mestrado em Engenharia Urbana)- Universidade Federal da Paraíba, João Pessoa, 2005.

OLIARI, Deivi Eduardo. A semiótica: a base para a linguagem visual. In: Intercom 2004. XXVII Congresso Brasileiro de Ciências da Comunicação, 2004, Porto Alegre. Intercom, 2004.

OLIVEIRA, José Luciano Agra de. Uma Contribuição aos Estudos Sobre a Relação Transporte e Crescimento Urbano: O Caso de João Pessoa. 2006. 195 f. Dissertação (Mestrado em engenharia Urbana)- Universidade Federal da Paraíba, João Pessoa, 2006.

OMT. Organização Mundial do Turismo. El turismo internacional mantendrá um crecimiento fuerte em 2013. Madrid: OMT, 2013. Disponível em: <WWW.media.unwto.org/es/press-release/2013-01-29/el-turismo-internacionalmantendra-uncrecimiento-fuerte-en-2013>. Acesso em: 25 jun. 2014. 
OMT/UNWTO. Organização Mundial do Turismo. World Tourism Barometer. v. 7, n. 1, jan. 2009. Disponível em: <www.tourlib.net/wto/UNWTO_Barometer_2009_01.pdf>. Acesso em: 25 jun. 2014.

ORLANDI, Eni Puccinelli. As formas do silêncio: no movimento dos sentidos. Campinas: UNICAMP, 1997.

PAESE, Joel. Fim da sociedade do trabalho ou imprecisão no debate? Revista Mediações. Londrina, v. 7, n. 1, p. 183-196, jan. /jul., 2002.

PALMEIRA, Balila; DIAS, Messina Palmeira. Bairro do Miramar: sua história, seus moradores. João Pessoa: Grafset, 1997.

PAUliNO, Maria da Conceição Pereira. História e urbanização: liminaridades no Parque Sólon de Lucena, João Pessoa-PB. In: ENCONTRO NACIONAL DA ASSOCIAÇÃO NACIONAL DE PESQUISA E PÓS-GRADUAÇÃO EM ARQUITETURA E URBANISMO, 1, 2010, Rio de Janeiro, 2010.

PINTO, Irineu Ferreira. Dados e Notas de para a História da Paraíba . João Pessoa: Editora Universitária / UFPB, 1977, p. 101. Vol. II.

RABAHY, Wilson Abrahão. Aspectos do turismo mundial, situação e perspectivas desta atividade no Brasil. Observatório de Inovação do Turismo - Revista Acadêmica. vol. 1, n. 1, 2006.

RODRIGUES, Arlete Moisés. A produção e o consumo do espaço para o turismo e a problemática ambiental. In: YÁZIGI, Eduardo; CARLOS, Ana Fani Alessandri; CRUZ, Rita de Cássia Ariza da. Turismo: espaço, paisagem e cultura. São Paulo: Hucitec, 2002, p. 55-62.

RODRIGUEZ, Janete Lins. Acumulação de capital e produção do espaço: o caso da grande João Pessoa. João Pessoa: Editora Universitária/UFPB, 1980.

RODRIGUEZ, Janete Lins; DROULERS, Martine. João Pessoa, crescimento de uma capital. João Pessoa: Fundação Casa de José Américo, 1981.

SÁ, Nirvana Lígia Albino Rafael de. A cidade no despertar da era higiênica: A Cidade da Parahyba e o Movimento Higienista (1854-1912). 2009. 154 f. Dissertação (Mestrado em Geografia)- Universidade Federal da Paraíba, João Pessoa, 2009.

SALES, Andréa Leandro Porto. O centro principal de João Pessoa: espacialidade, historicidade e centralidades. 2009. 141 f. Dissertação (Mestrado em Geografia) Universidade Federal da Paraíba-PPGG/CCEN. 2006.

SANCHEZ, Fernanda. A reinvenção das cidades para um mercado mundial. Chapecó, SC: Argos, 2010. 555 p.

SANSOLO, Davis Gruber; CRUZ, Rita de Cássia Ariza da. Plano Nacional do Turismo: uma análise crítica. In. Caderno Virtual de Turismo, v. 3, n. 4, 2003. 
SANTOS, Carlos Nelson F. dos. A cidade como um jogo de cartas. Niterói: EDUFF, 1988. $192 \mathrm{p}$.

SANTOS, Milton. A natureza do espaço: Técnica e tempo. Razão e emoção. São Paulo: HUCITEC, 1997.

SANTOS, Milton. A urbanização brasileira. São Paulo: HUCITEC, 1993.

SANTOS, Milton. Ensaios sobre a urbanização latino-americana. São Paulo: HUCITEC, 1982. 194 p.

SIQUEIRA, Kênia Mara de Freitas. Estudo toponímico: âmbitos e perspectivas de análises. REVEL, v. 9, n. 17, 2011 [www.revel.inf.br]

SOARES, Maria Simone Morais; MAIA, Doralice Satyro; MOURA FILHA, Maria Berthilde de Barros Lima. As transformações do uso do solo da avenida João Machado em João Pessoa - PB. In: SEMINÁRIO INTERNACIONAL URBICENTROS, 3., Salvador. Anais eletrônicos... Salvador: UFBA, 2012. Disponível em: <www.ppgau.ufba.br/urbicentros/2012/ST166.pdf>. Acesso em: 19 dez. 2013.

SOUZA JÚNIOR, Xisto Serafim de Santana de; ITO, Claudemira Azevedo. Turismo e espaço: uma leitura geográfica da interferência da atividade turística no processo de (re)organização sócio-espacial do município de João Pessoa-PB. Scripta Nova, Revista Electrónica de Geografía y Ciencias Sociales. Barcelona, v. 9, n. 194 (116), ago. 2005.

SPOSATI, Aldaíza (coord.); RAMOS, Frederico; KOGA, Dirce; CONSERVA, Marinalva; SILVEIRA JR., Constantino; GAMBARDELLA, Alice. Topografia Social de João Pessoa. João Pessoa: Cedest/IEE/PUCSP, 2009.

TAVARES, João de Lira. Apontamentos para a história territorial da Parahyba. Edição Fac-similar. Coleção Mossoroense. vol. CCXLV, 1982.

ULLER, Adriana Salviato. Cartografia Turística: uma leitura dos mapas temáticos de uso do turista em Ponta Grossa - Paraná. Tese (Doutorado em Geografia Física) Universidade de São Paulo, São Paulo, 2010.

VALENTE, Nelson; BROSSO, Rubens. Elementos de semiótica: comunicação verbal e alfabeto visual. São Paulo: Panorama, 1999.

VIDAL, Wylnna Carlos Lima. Transformações urbanas: a modernização da capital Paraibana e o desenho da cidade, 1910- 1940. 2004. 131 f. Dissertação (Mestrado em urbanismo)- Universidade Federal da Paraíba, João Pessoa, 2004.

VITTE, Claudete de Castro Silva. Inovações e permanências na gestão de cidades e na gestão do desenvolvimento local no Brasil: novas contradições, novos conteúdos? In: CARLOS, Ana Fani; LEMOS, Amália Inês Geraiges Lemos (orgs) Dilemas urbanos: novas abordagens sobre a cidade. São Paulo: Contexto, 2003. 430 p.

WTTC - World Travel \& Tourism Council. Travel \& Tourism Economic Impact 2012 Brazil. London: $2012 . \quad$ WTTC, Disponível em: 
<www.wttc.org/site_media/uploads/downloads/brazil2012.pdf $>$. Acesso em: 25 jun. 2014

WTTC - World Travel \& Tourism Council. Travel \& Tourism Economic Impact 2014 World. London: WTTC, $2014 . \quad$ Disponível em: <www.wttc.org/site_media/uploads/downloads/world2014.pdf>. Acesso em: 25 jun. 2014.

WTTC. World Travel \& Tourism Council. The Travel \& Tourism Competitiveness Report 2011: Beyond the Downturn. 2011. Disponível em: <http://www3.weforum.org/docs/WEF_TravelTourismCompetitiveness_Report_2011.p df>. Acesso em: 25 jun. 2014. 


\section{APÊNDICE - MAPAS}

Este apêndice trata-se de um fichário elaborado com anotações sobre os mapas analisados, incluindo a ilustração de cada mapa. Neste fichário constam organizados cronologicamente, 48 mapas, do universo de 67 mapas analisados nesta pesquisa. 


\section{Ficha 1}

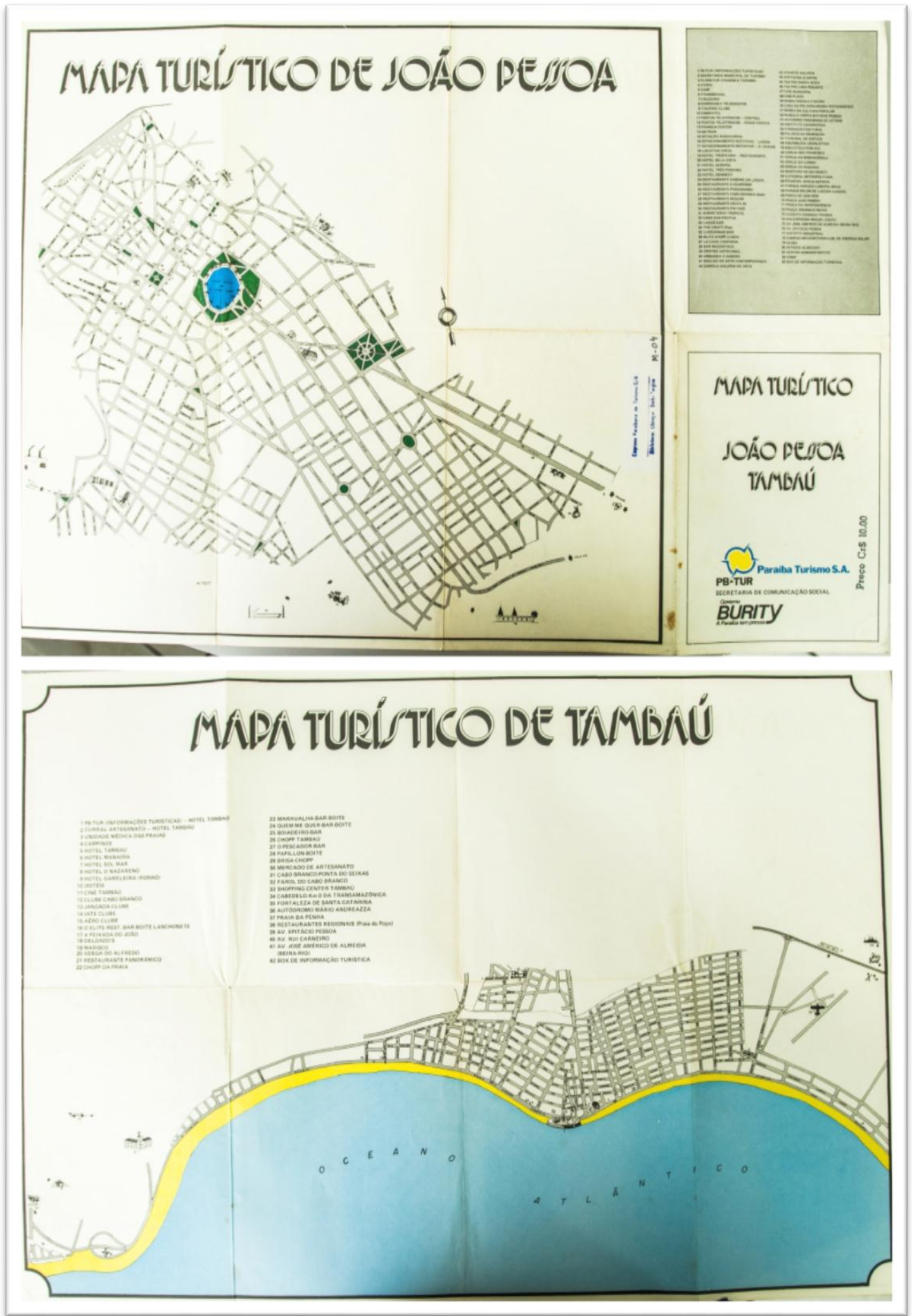

Mapa-Ficha 1 - Mapa turístico em formato de folder dobrável com o título "Mapa Turístico - João Pessoa - Tambaú”. Data aproximada: 1979-1982. 
Ficha 1 - Período/Ano de publicação: Data aproximada 1979 - 1982

Observações: O período de publicação foi presumido a partir do preço do mapa que aparece na capa, CR \$10,00 - Dez Cruzeiros - Moeda usada neste período, que coincide também com o período do governo de Tarcísio de Miranda Burity, que também aparece no folder)

Breve descrição: Material impresso em formato de folder dobrável, com dois mapas, dispostos um em cada lado. Apresenta a cidade como se a mesma possísse duas partes separadas, o centro da cidade e a orla de CaboBranco, Tambaú e Manaíra.

Tipo de suporte (folder, encarte, para parede, etc): Folder

Título do folder: Mapa Turístico - João Pessoa - Tambaú

Título do mapa: Mapa1: Mapa turístico de Tambaú. Mapa 2: Mapa turístico de João Pessoa.

Ponto de vista do observador: Vista vertical, característica de planta urbana

Foto da capa: Não consta

Escala: Não consta

Rosa dos ventos: Sim

Os limites representados (as bordas do espaço representado): $\mathrm{Na}$ borda inferior o mapa limita-se pelos bairros de Jaguaribe e Torre; Na borda esquerda o bairro de Jaguaribe e Centro; Na borda superior o Varadouro e na borda direita o bairro da Torre e as proximidades da avenida Epitácio Pessoa.

Público alvo: Turistas em geral

Slogans e/ou frases de efeito: "Governo Burity, a Paraíba tem pressa"

Principais pontos ou locais destacados: A Lagoa e o Hotel Tambaú

Topônimos citados: Nome das ruas. Cabo Branco, Ponta do Seixas, Fortaleza de Santa Catarina, Cabedelo Km 0 da Transamazônica, Farol do Cabo Branco, Praia da Penha,

Instituição responsável por propor ou encomendar o mapa: Governo do Estado/PBTUR

Empresa responsável pela execução do projeto, impressão do mapa: Não consta

Governador da época: Tarcísio de Miranda Burity

Autor do mapa: Não identificado. 


\section{Ficha 2}

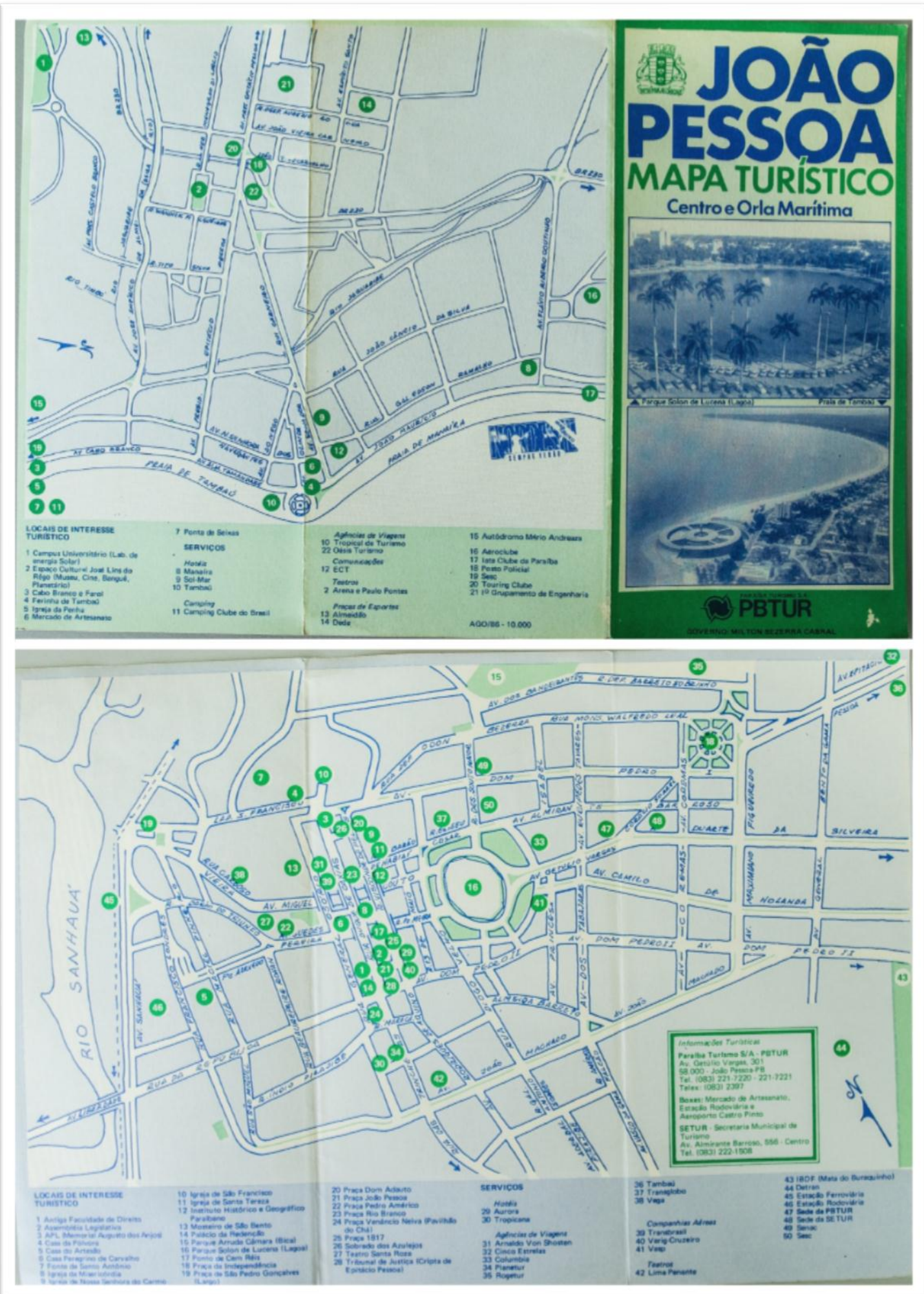

Mapa-Ficha 2 - Mapa impresso em formato de folder dobrável com o título "João Pessoa - Mapa Turístico - Centro e Orla Marítima". A figura superior ilustra o lado em que consta a capa e o mapa da orla marítima. A figura inferior ilustra o mapa do Centro da cidade. Data: 1986 
Ficha 2 - Período/ano da publicação: Agosto de 1986

Breve descrição: Mapa turístico em formato de folder dobrável e impresso em frente e verso. Apresenta dois mapas, um representa a área litorânea da cidade e o outro o centro da cidade.

Tipo de suporte (folder, encarte, para parede, etc.): Folder impresso e dobrável.

Título do folder: João Pessoa - Mapa Turístico - Centro e Orla Maritma

Título do mapa: Os mapas não apresentam títulos.

Ponto de vista do observador (ou usuário do mapa): Vista vertical característica de planta urbana.

Foto da capa do folder: A capa ilustra uma dualidade de setores turísticos na cidade, o centro e a orla marítima. Duas fotos ilustram a capa, uma foto da Lagoa do Parque Solon de Lucena e a foto da praia de Tambaú, tendo como destaque o Hotel Tambaú.

Escala: Não consta

Rosa dos Ventos: Sim

Os limites representados (ou as bordas do espaço representado pelo mapa):

O mapa do centro da cidade representa exclusivamente esta área, tendo como ponto central a Lagoa do Parque Solón de Lucena. O mapa da orla marítima tem como limites, ao norte a praia de Manaíra, ao sul a praia de Tambaú. Este mapa representa cerca de 2 $\mathrm{Km}$ em linha reta na direção Leste-Oeste, ou no sentido do Mar para o Centro da cidade, tomando como ponto inicial o Hotel Tambaú.

Público alvo: Turistas em geral.

Slogans e/ou frases de efeito: Não constam.

Principais pontos ou locais destacados: No mapa da orla o ponto em destaque é o Hotel Tambaú. No mapa do Centro da cidade o destaque é a Lagoa do Parque Solón de Lucena.

Topônimos citados: Nos dois mapas são citados apenas os nomes de alguns rios, os nomes das principais ruas e os nomes das duas praias representadas, Tambaú e Manaíra.

Instituição responsável por propor ou encomendar o mapa: Governo do Estado / PBTUR

Empresa responsável pela execução do projeto, impressão do mapa: Não identificada.

Governador da época: Milton Bezerra Cabral

Autor do mapa: Não identificado. 


\section{Ficha 3}

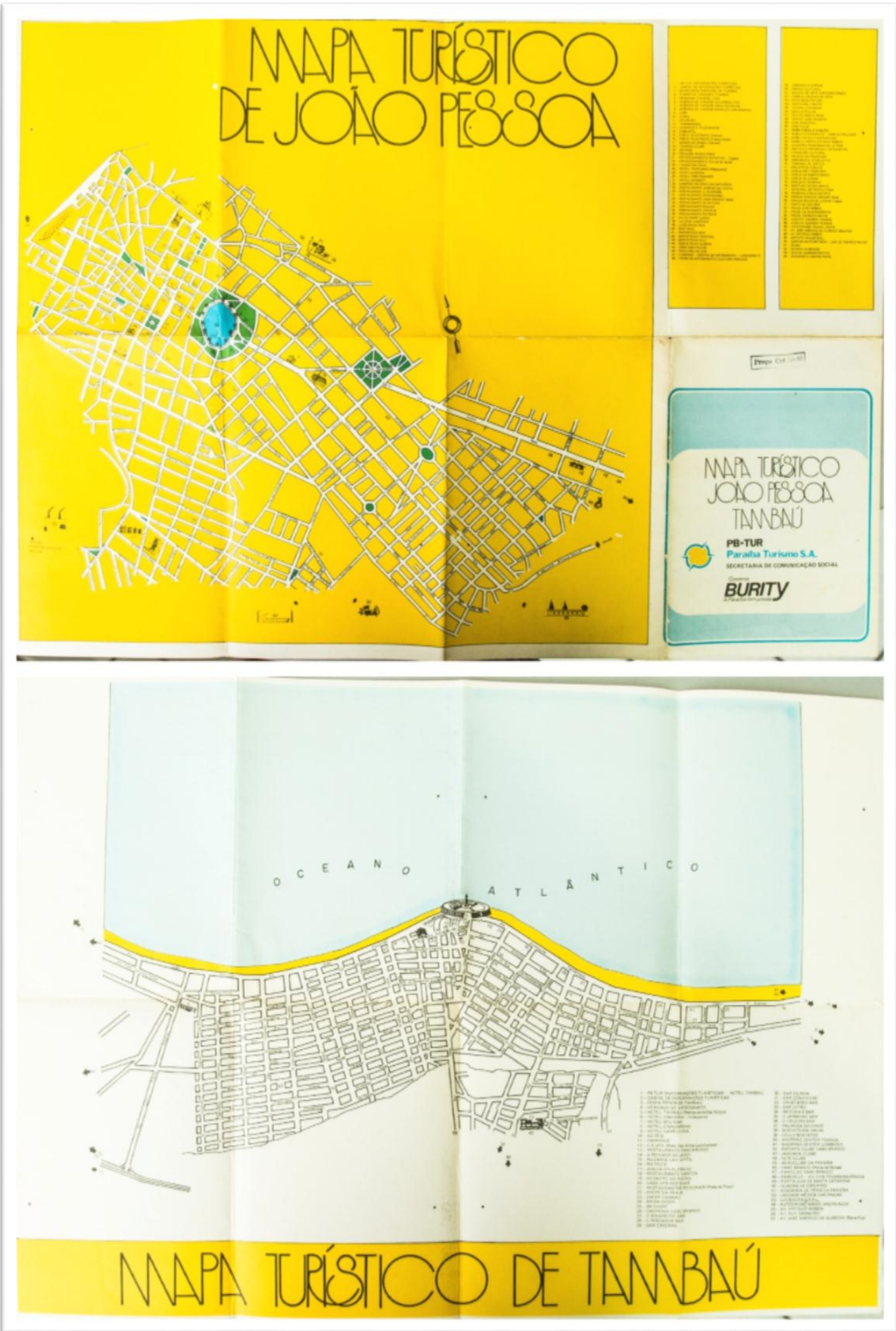

Mapa-Ficha 3 - Mapa impresso em fortato de folder dobrável de título "Mapa Turístico - João Pessoa - Tambaú”. Data aproximada: 1987 a 1991. 
Ficha 3 - Período/ano da publicação: Período aproximado 1987-1991.

Observações: A data do mapa foi estimada pela indicação da gestão do Governo do Estado de Tarcísio de Miranda Burity (que governou em dois períodos: de 1979 a 1982 e posteriormente de 1987 a 1991);

Dá para perceber, no mapa, uma separação entre a praia de Tambaú e a outra parte da cidade, como se houvesse uma separação entre as duas áreas.

Breve descrição: Folder, exclusivamente com os dois mapas. Não consta nenhuma publicidade nem texto sobre a cidade ou a Paraíba.

Tipo de Suporte (folder, encarte, para parede, etc): Folder.

Título Folder: Mapa Turístico - João Pessoa - Tambaú

Título do Mapa: Título do mapa do Centro: Mapa Turístico de João Pessoa; Título do mapa da orla: Mapa Turístico de Tambaú.

Ponto de vista do observador(ou usuário do mapa): Vista vertical característica de planta urbana.

Foto da capa: Não há foto na capa. A capa apresenta apenas um título para o mapa e o órgão responsável.

Destaque principal: Na capa o destaque está no nome do governador.

Escala: Não consta.

Rosa dos ventos: Sim

Os limites representados (as bordas do espaço representado): $\underline{O}$ mapa do centro limita o espaço da cidade que compreende a área conhecida como o centro da cidade. Ao norte o limite é Parque Arruda Câmara, a Bica. Ao sul o mapa tem limite na Ceasa e no Estádio Almeidão. A leste tem limite na Av. Epitácio Pessoa próximo aos Bairros dos Estados e Expedicionários, e a oeste os limites são o Rio Sanhauá e o Distrito industrial. O mapa da orla limita-se a representar os bairros de Manaíra, Tambaú e Cabo Branco.

Público Alvo: Turistas em geral

Slogans e/ou frases de efeito: "A Paraíba tem pressa".

Principais pontos ou locais destacados: No mapa do centro da cidade o destaque é a Lagoa do Parque Solon de Lucena. No mapa de Tambaú o destaque é o hotel Tambaú, localizado no centro do mapa de uma forma que o desenho dá a impressão que o hotel de encontra num ponto elevado.

Topônimos citados: Nomes de ruas e o Oceano Atlântico

Instituição responsável por propor ou encomendar o mapa: Governo do Estado / PBTUR.

Empresa responsável pela execução do projeto, impressão do mapa: Não identificada. Governador da época: Tarcísio de Miranda Burity

Autor do mapa: Não identificado. 


\section{Ficha 4}

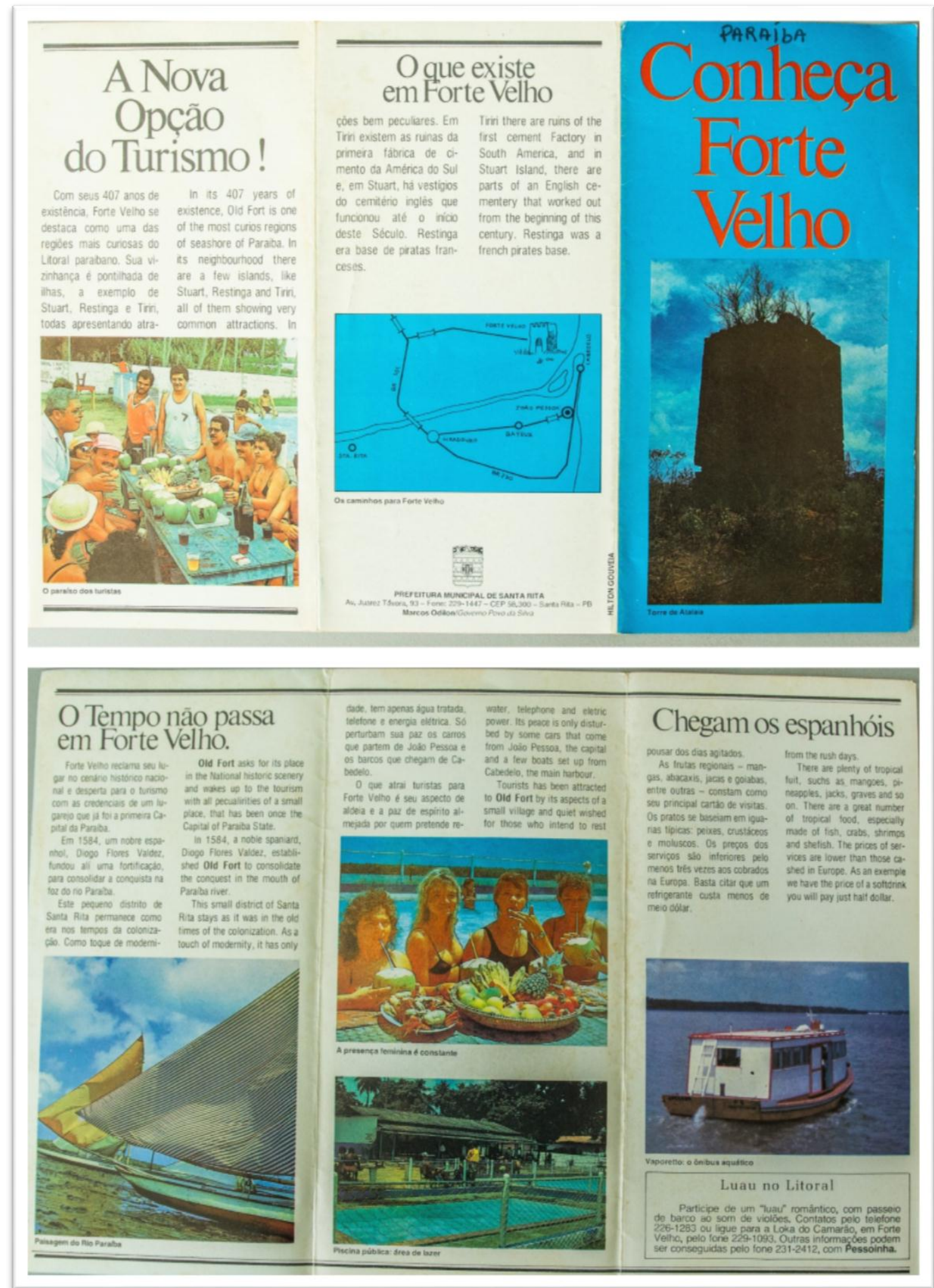

Mapa-Ficha 4 - Mapa turístico em formato de folder com o título "Conheça Forte Velho". Data: 1989. 
Ficha 4 - Período/Ano de publicação do mapa: 1989.

Observações: ano presumido através da informação do nome do prefeito da época.

Breve descrição: Folder turístico voltado à localidade conhecida como Forte Velho.

Consta um mapa dos caminhos para se chegar à Forte Velho, sem escala e sem indicação do Norte.

Observação: a frase "a presença feminina é constante" faz uma propaganda velada da prostituição feminina.

Tipo de suporte (folder, encarte, para parede, etc): Folder

Título do Folder: Conheça Forte Velho.

Foto da capa: Fotografia das ruínas de Atalaia.

Título do Mapa: Os caminhos para Forte Velho

Ponto de vista do observador (ou usuário do mapa): Mapa de vista vertical.

Foto da capa: Foto da Torre de Atalaia.

Escala: Não consta

Rosa dos ventos: Não consta.

Os limites representados (as bordas do espaço representado): A área de Bayeux, Santa Rita, Cabedelo e Forte Velho.

Publico alvo: Turistas

Slogans e/ou frases de efeito: "A nova opção do turismo" "O tempo não passa em Forte Velho".

Topônimos citados: Forte Velho, Ilha da Restinga, Ilha do Stuart, Ilha de Tiriri.

Instituição responsável por propor ou encomendar o mapa: Prefeitura da cidade de Santa Rita.

Empresa responsável pela execução do projeto, impressão do mapa: Não consta.

Prefeito da época: Marcos Odilon

Autor do mapa: Não consta. 


\section{Ficha 5}

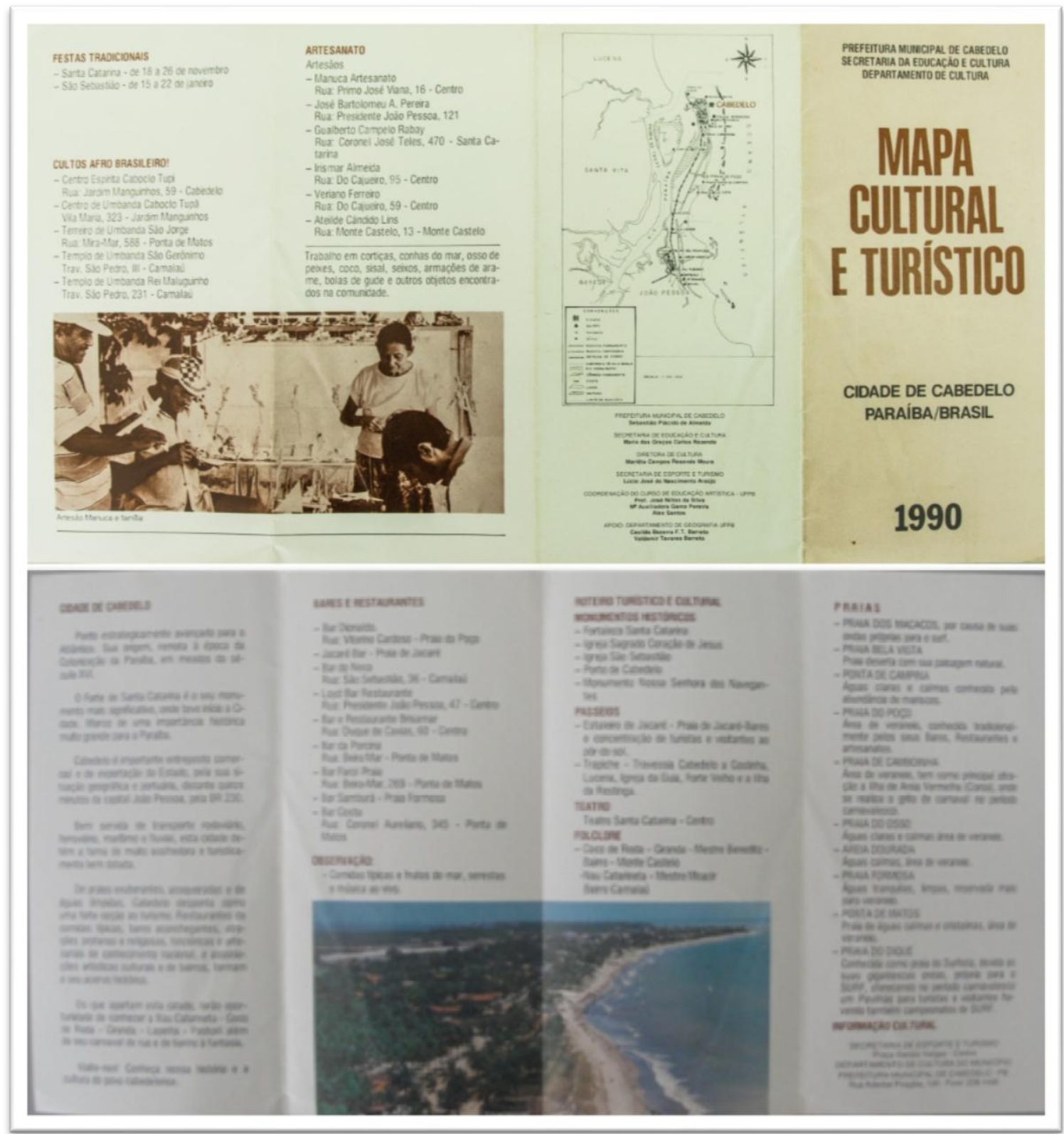

Mapa-Ficha 5 - Mapa Cultural e Artístico - Cidade de Cabedelo/Paraíba- Brasil.

Data: 1990. 
Ficha 5 - Período/ano da publicação: Ano de 1990

Breve descrição: Folder dobrável, impresso em frente e verso. Apresenta a Cidade de Cabedelo com enfoque principal na cultura local. Apresenta dois lados com indicação dos principais pontos de interesse turístico e cultural da cidade, incluindo um pequeno mapa. Nota-se que o folder como um todo e as informações escritas contidas nele são as principais fontes de informação, o mapa é apenas uma pequena parte do folder.

Tipo de suporte (folder, encarte, para parede, etc): Folder

Título do folder: Mapa Cultural e Artístico - Cidade de Cabedelo/Paraíba/Brasil

Título do mapa: Não consta título

Ponto de vista do observador (ou usuário do mapa): Visão vertical.

Foto da capa: A capa do folder não apresenta foto.

Escala: 1:100.000

Rosa dos ventos: Sim.

Os limites representados (ou as bordas do espaço representado pelo mapa): O limite do mapa concentra o município em sua totalidade. Consideramos a escala não apropriada para o detalhamento necessário às necessidades do turista.

Público alvo: Turistas interessados em aspectos culturais de populações locais.

Slogans e/ou frases de efeito: Não identificado.

Topônimos citados: Os municípios de Lucena, Santa Rita, Bayeux, João Pessoa e Cabedelo. Os rios Canal da Ribeira e Paraíba. Praias: Praia do Dique, Praia de Matos, Praia Formosa, Areia dourada, Praia do Osso, Praia de Camboinha, Praia do Poço, Ponta de Campina, Bela Vista. A Ilha da Restinga. Praia do Jacaré. Os Bairros de Camalaú, Vila Leonor, Salina São Francisco, Jardim América, Salina Ribamar, Bairro Gonçalo, Intermares na cidade de Cabedelo e o Bairro do Bessa em João Pessoa.

Instituição responsável por propor ou encomendar o mapa: Prefeitura Municipal da Cidade de Cabedelo.

Empresa responsável pela execução do projeto, impressão do mapa: Não identificada Prefeito da época: Sebastião Plácido de Almeida (prefeito de Cabedelo)

Autor do mapa: Equipe de geógrafos da UFPB - Cacilda Bezerra T. Barreto e Waldemir Tavares. Barreto 


\section{Ficha 6}

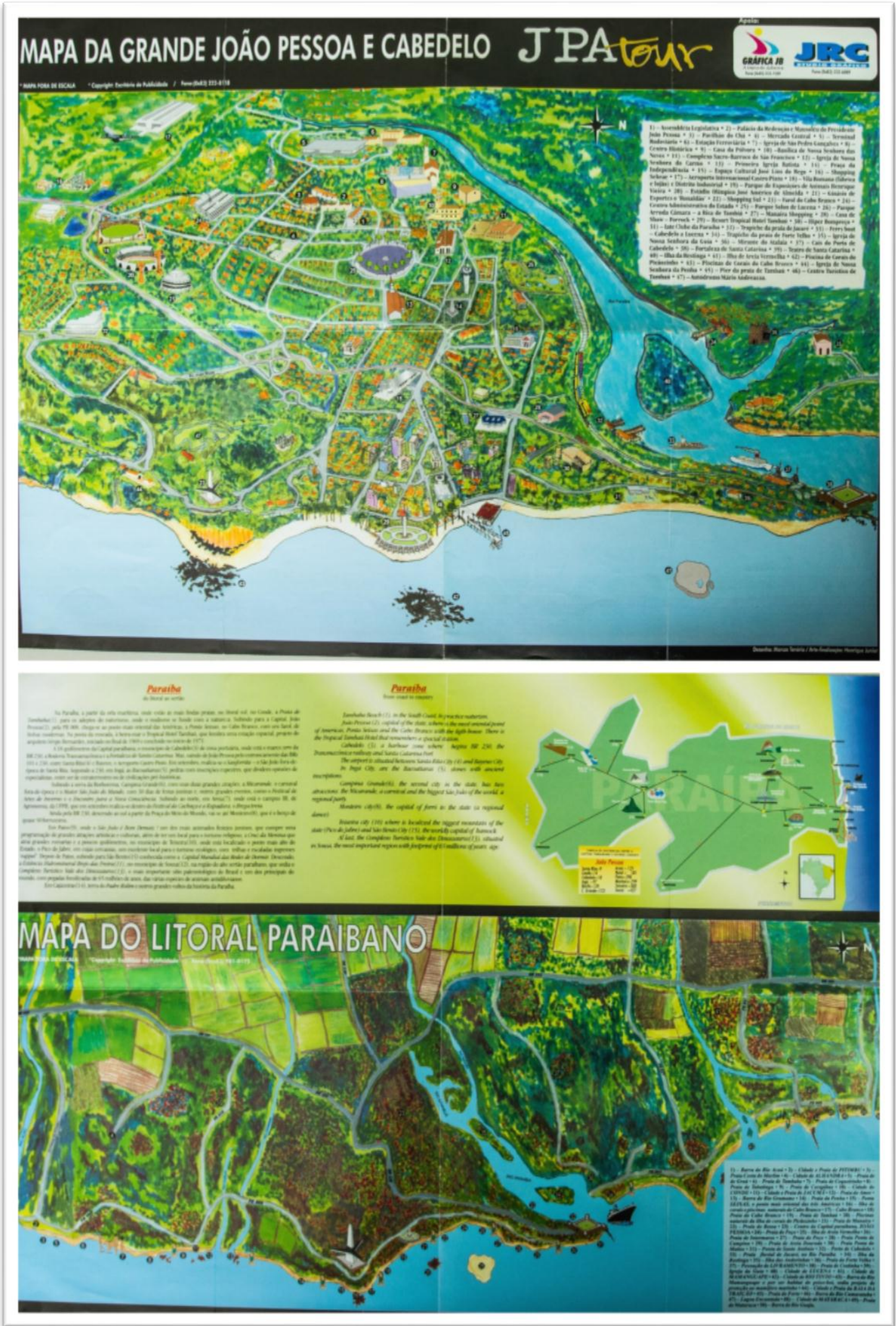

Mapa-Ficha 6 - Material impresso em frente e verso contendo dois mapas: Mapa da Grande João Pessoa e Cabedelo e Mapa do litoral paraibano. Década de 1990. 
Ficha 6 - Período/ano da publicação: Década de 1990.

Breve descrição: Folha única, com dois mapas turísticos, cada mapa impresso em um dos lados da folha. Existe um texto no mapa de título, "Mapa do Litoral Paraibano", que faz uma apresentação rápida de todo o Estado, considerando algumas cidades como, João Pessoa, Cabedelo, Bayeux, Sta Rita, Campina Grande, Ingá, Areia, Monteiro, Patos, Teixeira, São Bento, Souza e Cajazeiras. Existe também, neste mesmo mapa, um texto de orientação para os turistas escrito em inglês.

Tipo de suporte (folder, encarte, para parede, etc): Mapa avulso

Títulos dos mapas: Mapa da Grande João Pessoa e Cabedelo.

Mapa do litoral paraibano

Ponto de vista do observador (ou usuário do mapa): visão de leste para oeste.

Foto da capa: Não consta capa.

Escala: Não consta.

Rosa dos ventos: Sim

Os limites representados (ou as bordas do espaço representado pelo mapa):

No mapa intitulado "Mapa da Grande João Pessoa e Cabedelo": na borda do lado direito do mapa, estão o Forte de Santa Catarina localizado no município de Cabedelo e a Igreja da Guia localizada no município de Lucena.

Na borda esquerda do mapa, ao sul do município, os limites são o bairro de Mangabeira e as proximidades do Viaduto das Três Lagoas. Não consta nenhuma toponímia dos bairros, os limites foram identificados através de pontos turísticos destacados, numerados e organizados em legenda.

Na borda inferior do mapa (a leste) está a orla marítima compreendida entre o Forte de Santa Catarina e o Rio do Cabelo, localizado próximo à Praia da Penha.

Na borda superior do mapa (a oeste) os limites são o Rio Sanhauá, o terminal rodoviário e a estação ferroviária.

No mapa intitulado "Mapa do litoral paraibano": Este mapa representa apenas uma estreita faixa do litoral do Estado. Os limites ao sul são a Praia de Mataraca e ao norte a Barra do Rio Acaú e a cidade de Pitimbu.

Público alvo: Turistas nacionais e estrangeiros.

Slogans e/ou frases de efeito: "Paraíba: do litoral ao sertão".

Principais pontos ou locais destacados:

Topônimos citados: Rio Paraíba e Rio do Cabelo. Constam também os nomes das principais ruas e avenidas.

Instituição responsável por propor ou encomendar o mapa: Não identificada.

Empresa responsável pela execução do projeto, impressão do mapa: Gráfica JB / JRC Studio gráfico

Autor do mapa: Desenho: Marcos Tenório. Arte-finalização: Henrique Júnior 


\section{Ficha 7}

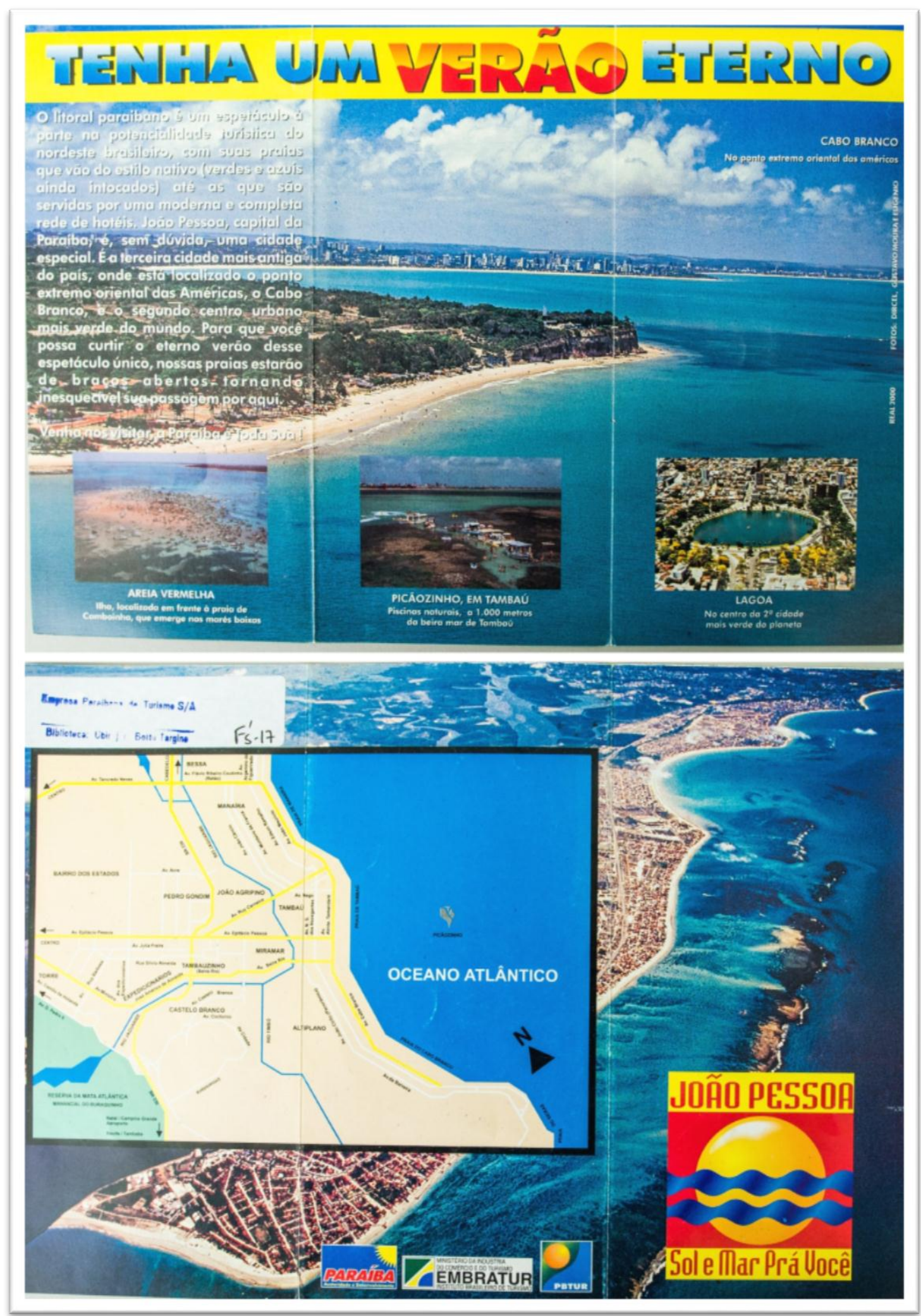

Mapa-Ficha 7 - Mapa impresso em formato de folder com o título "João Pessoa - Sol e Mar prá você”. Data da publicação: Final da década de 1990. 
Ficha 7 - Período/Ano de publicação: Final dos anos 1990

Breve descrição: Folder institucional dobrável com dois lados, em um dos lados consta um mapa de parte da cidade de João Pessoa; do outro lado destaca-se a Praia do Seixas, a Ponta do Cabo Branco e o farol. Constam também deste lado três fotos menores: da Lagoa do Parque Solon de Lucena, dos corais de Picãozinho e da Ilha de Areia Vermelha. Tipo de suporte (folder, encarte, para parede, etc): Folder

Título do folder: JOÃO PESSOA - Sol e Mar prá você

Título do mapa: Não consta.

Ponto de vista do observador (ou usuário do mapa): Vista vertical característica de planta urbana.

Foto da capa: Fotografia aérea de parte do litoral do Estado. (Foto: Dirceu, Gustavo Moura e Eugênio.)

Escala: Não consta

Rosa dos ventos: Sim.

Os limites representados (as bordas do espaço representado):

Borda do lado direito (leste) a faixa litorânea.

Borda do lado inferior (Sul) a Praia do Seixas e a Mata do Buraquinho.

Borda lateral esquerda (oeste) a Mata do Buraquinho, a Av. Camilo de Holanda e o Bairro dos Estados.

Borda superior (norte) as avenidas Tancredo Neves e Flávio Ribeiro Coutinho.

Público alvo: Turistas em geral.

Slogans e/ou frases de efeito: "Sol e Mar Prá Você"

"Tenha um verão eterno"

"... segunda cidade mais verde do planeta"

"... ponto extremo oriental das Américas"

"É a terceira cidade mais antiga do país"

Principais pontos ou locais destacados: Areia Vermelha, Picaozinho, Lagoa do Parque Solon de Lucena, Ponta do Cabo Branco.

Topônimos citados: Praias: Manaíra, Tambaú, Cabo Branco e Seixas. Os Corais de Picãozinho, Principais avenidas. Os bairros: Bessa, Manaíra, Tambaú, Miramar, Altiplano, Castelo Branco, Expedicionários, Tambauzinho, Torre, Bairro dos Estados, Pedro Gondim, João Agripino, Manancial do Buraquinho, Rios: Jaguaribe e Timbó.

Instituição responsável por propor ou encomendar o mapa: Governo do Estado / PBTUR

Empresa responsável pela execução do projeto, impressão do mapa: REAL 2000

Governador da época: José Targino Maranhão

Autor do mapa: Não identificado. 


\section{Ficha 8}

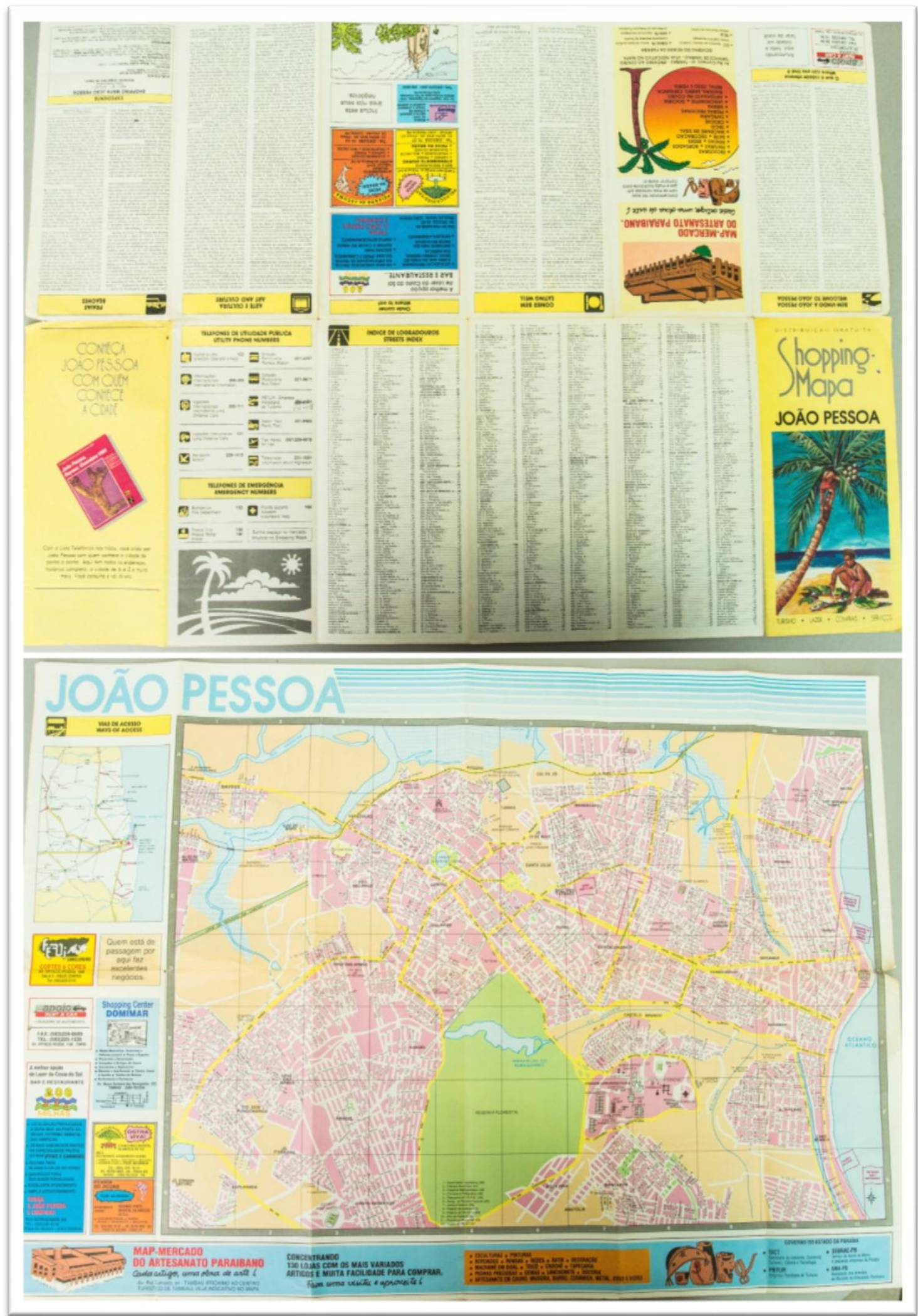

Mapa-Ficha 8 - Material de publicidade do Shopping Manaíra contendo um mapa da cidade. Título do folder: "Shopping Mapa - João Pessoa - Turismo - Lazer - Compras - Serviços”. Título do mapa: João Pessoa. Data: 1991. 
Ficha 8 - Período/ano de publicação: 1991

Breve descrição: Folder publicitário contendo, de um lado, um mapa-planta de parte da cidade e do outro, várias informações turísticas, como: textos de apresentação da cidade com aspectos da culinária, artes, e praias/Telefones úteis/um índice de logradouros e ruas. Quanto ao mapa é o mesmo mapa utilizado nas antigas listas telefônicas da Listel que eram distribuídas gratuitamente por toda a cidade. Do lado direito deste mapa-planta da cidade consta outro mapa menor apenas com as principais vias de acesso dos municípios do litoral do Estado. Logo abaixo deste mapa menor, estão anúncios publicitários de diversas empresas. Por toda a borda inferior do mapa está preenchida com a publicidade do MAP - Mercado de Artesanato da Paraíba. Poucas empresas (cinco), além do Shopping Manaíra aparecem fazendo publicidade: Rent a car - Locadora de automóveis/ Roccas - Bar e restaurante / Peixada do Jacumã- Restaurante / Palhoça do Seixas Restaurante / 200 Milhas - Bar e restaurante.

Tipo de suporte (folder, encarte, para aprede, etc): Folder publicitário do Manaíra Shopping.

Título do folder: Shopping Mapa - João Pessoa - Turismo - Lazer - Compras - Serviços

Título do mapa: João Pessoa.

Ponto de vista do observador (ou usuário do mapa): Perspectiva de sul para norte.

Foto da capa: A capa é um desenho de um coqueiro à beira mar com um "tirador de côco" subindo no coqueiro. Sob o coqueiro outro homem com uma faca na mão, prepara um peixe que está colocado ao chão sobre umas folhas parecidas com folhas de palmeiras. Imagem que remete à um tempo primitivo.

Escala: Não consta.

Rosa dos Ventos: Consta.

Os limites representados (as bordas do espaço representado):

$\mathrm{Na}$ borda inferior (sul) os limites são os bairros: Bancários, Anatólia, Cristo Redentor, Esplanada e Ernani Sátiro, além da Mata do Buraquinho.

$\mathrm{Na}$ borda lateral esquerda (norte) os limites são os bairros Ernani Sátiro e Alto do Mateus e o município de Bayeux.

Na borda superior (norte) os limites são os rios Sanhauá e Paroeira, os Bairros Varadouro, Rogers e Padre Zé.

$\mathrm{Na}$ borda lateral direita (leste) está a faixa do litoral com as praias do Bessa, Manaíra, Tambaú e Cabo Branco.

Público Alvo: Turistas nacionais e estrangeiros.

Slogans e/ou frases de efeito: “... o ponto extremo oriental das Américas”.

Principais pontos ou locais destacados: As cinco empresas que aparecem fazendo publicidade: Rent a car - Locadora de automóveis/ Roccas - Bar e restaurante / Peixada do Jacumã- Restaurante / Palhoça do Seixas - Restaurante / 200 Milhas - Bar e restaurante.

Topônimos citados: Todas as ruas da cidade e todos os bairros. Hotel Tambaú, $1^{\circ}$ Grupamento de Engenharia, Esp. Cultural, Penitenciária Modelo do Estado, Igreja São Francisco, Parque Solon de Lucena, Praça A. Navarro, Parque Arruda Câmara, Praça João Vinagre, Estádio José Américo, Estádio Robson Espínola, Estádio Olímpico, Estádio H. Henrique, Cemitério São José, $15^{\circ}$ Reg. De Infantaria, Manancial do Buraquinho, Rio 
Paroeiras, Rio Sanhauá, Rio Jaguaribe, Aeroporto Presidente Castro Pinto, Escola Técnica Federal, DETRAN, Centro Administrativo, Clube dos Oficiais, Aeroclube da Paraíba, Bayeux.

Instituição responsável por propor ou encomendar o mapa: Manaíra Shopping.

Empresa responsável pela execução do projeto, impressão do mapa: Divisão gráfica da Editora Abril S.A. /Publicação da LISTEL - Listas Telefônicas S.A. Editor responsável Wanderley Gregoriano de Castro. (Ano 1. Edição 1. №1)

Governador da época: Tarcísio de Miranda Burity.

Prefeito da época: Carlos Mangueira.

Autor do mapa: Não consta. 


\section{Ficha 9}

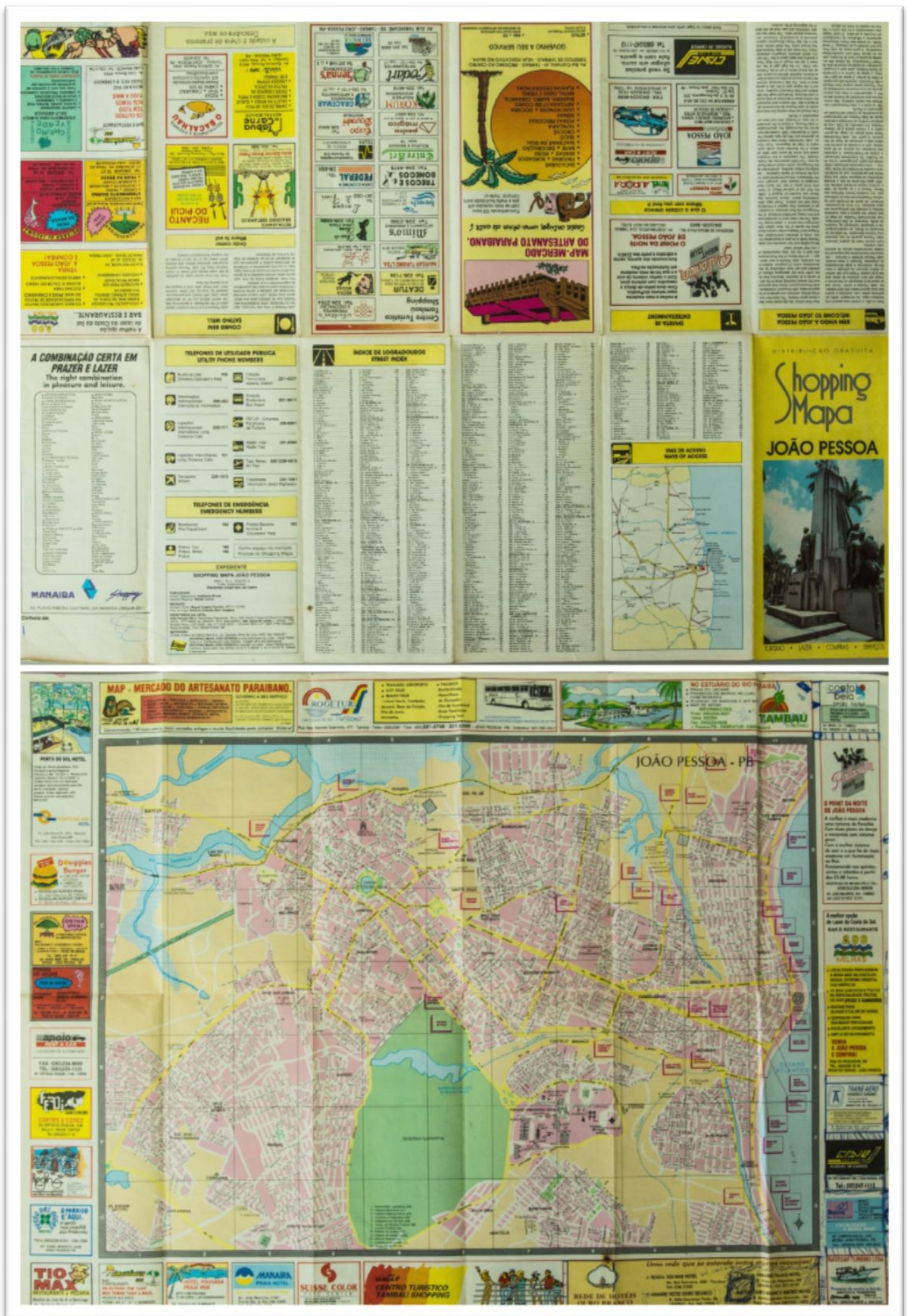

Mapa-Ficha 9 - Material de publicidade do Shopping Manaíra contendo um mapa da cidade. Título do folder: "Shopping Mapa - João Pessoa - Turismo - Lazer - Compras - Serviços". Data: provavelmente 1992. 
Ficha 9 - Período/Ano de publicação: Data provável: 1992.

Observação: Não apresenta claramente o ano da publicação, mas pode-se presumir que sua data seja da década de 1990, pois apresenta publicidade do Shopping Manaíra que foi inaugurado em 1989. No texto consta a frase “Espaço cultural inaugurado há dez anos...". A inauguração deste espaço foi realizada no dia 13 de abril de 1982. Além disso, este mapa possui uma numeração subsequênte à outro mapa de uma série semelhante.

Breve descrição: Folder publicitário contendo um mapa-planta de parte da cidade. $\mathrm{O}$ mapa é o mesmo mapa utilizado nas antigas listas telefônicas da Listel que eram distribuídas gratuitamente por toda a cidade. Ao redor do mapa, como uma borda, encontram-se diversos anúncios publicitários.

No interior do mapa estão indicados, indexados, os anunciantes exatamente no local do endereço do ponto comercial.

No lado oposto do mapa estão outras publicidades. Existem também, um texto sobre a cidade e algumas informações de utilidade pública.

Tipo de Suporte (folder, encarte, para parede, etc): Folder publicitário do Shopping Manaíra (outras empresas também fazem anúncios neste folder)

Título do folder: SHOPPING MAPA JOÃO PESSOA - Turismo - Lazer - Compras Serviços.

Título do mapa: Não consta.

Ponto de vista do observador (ou usuário do mapa): Vista vertical característica de planta urbana.

Foto da capa: Fotografia do Monumento a João Pessoa que se encontra na Praça João Pessoa, localizada no Centro da cidade.

Escala: Não consta.

Rosa dos ventos: Sim.

Os limites representados (as bordas do espaço representado): Borda superior Norte: Rio Paraíba, Bairros do Roger e Padre Zé, e para a direita o Bessa. Borda Lateral direitaLeste: Praia do Bessa ao norte, Manaíra, Tambaú e Cabo Branco ao sul. Borda inferior sul: Bancários, Anatólia, Água Fria, Cristo, Estádio Almeidão, Bairro Ernani Sátiro e Esplanada. Borda lateral oeste: Ernani Sátiro, Alto do Mateus e Bayeux.

Público alvo: Turistas, Possíveis clientes dos anunciantes. Consumidores em geral

Slogans e/ou frases de efeito: Não identificados.

Principais pontos ou locais destacados: os 34 estabelecimentos comerciais que constam localizados através de uma "placa" indicativa em seus respectivos endereços.

Topônimos citados: Nomes das ruas, Hotel Tambaú, Bairros, Cidade Universitária, 
Todas as ruas da cidade e todos os bairros. Hotel Tambaú, $1^{\circ}$ Grupamento de Engenharia, Esp. Cultural, Penitenciária Modelo do Estado, Igreja São Francisco, Parque Solon de Lucena, Praça A. Navarro, Parque Arruda Câmara, Praça João Vinagre, Estádio José Américo, Estádio Robson Espínola, Estádio Olímpico, Estádio H. Henrique, Cemitério São José, $15^{\circ}$ Reg. De Infantaria, Manancial do Buraquinho, Rio Paroeiras, Rio Sanhauá, Rio Jaguaribe, Aeroporto Presidente Castro Pinto, Escola Técnica Federal, DETRAN, Centro Administrativo, Clube dos Oficiais, Aeroclube da Paraíba, Bayeux

Instituição responsável por propor ou encomendar o mapa: Manaíra Shopping

Empresa responsável pela execução do projeto, impressão do mapa: Divisão gráfica da Editora Abril S.A. /Publicação da LISTEL - Listas Telefônicas S.A. Editor responsável Wanderley Gregoriano de Castro. (Ano 1. Nº 2. Edição 2).

Autor do mapa: Não identificado. 
Ficha 10

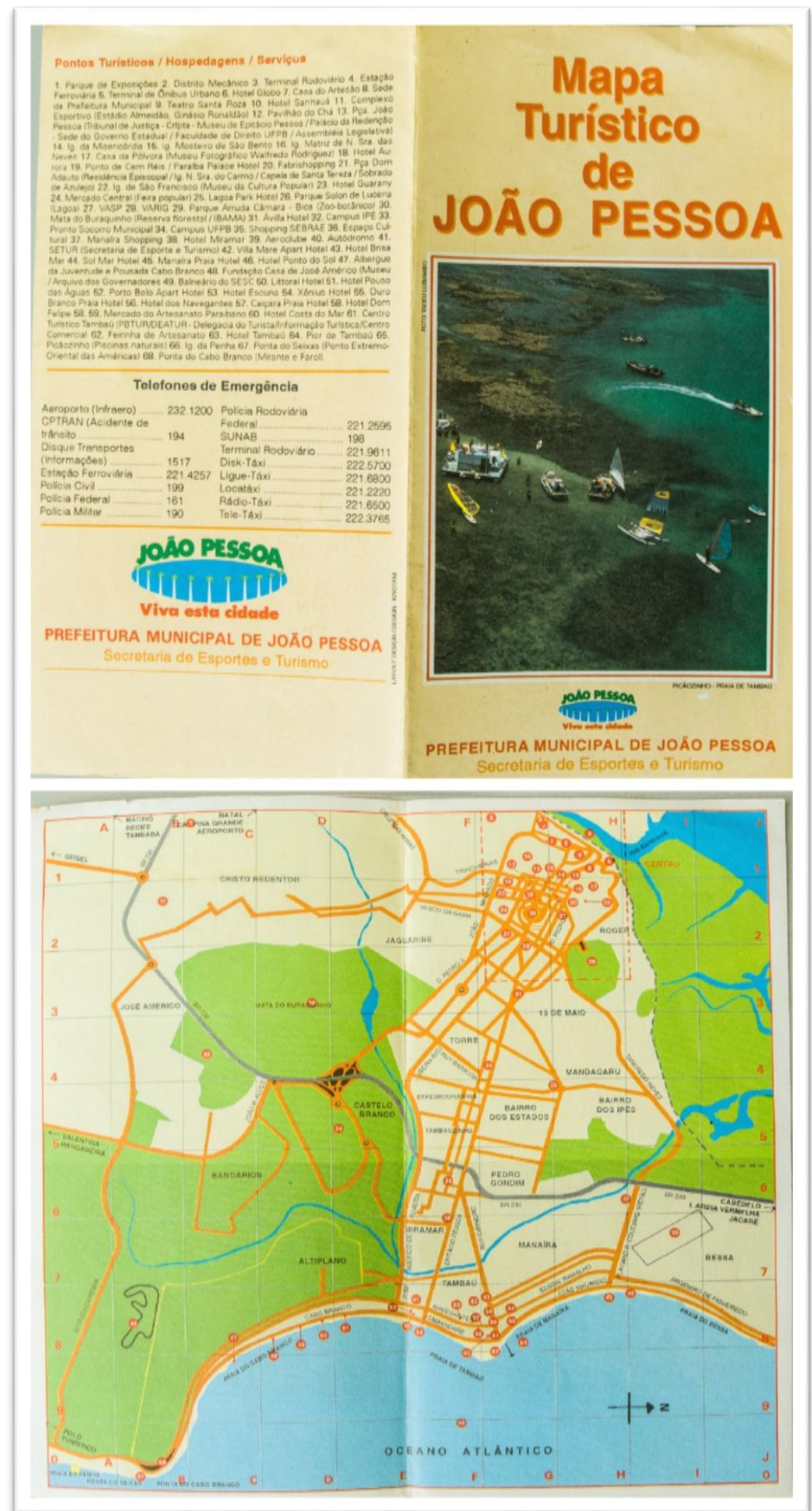

Mapa-Ficha 10 - Mapa turístico de João Pessoa elaborado pela Prefeitura Municipal de João Pessoa. Data: aproximadamente 1994. 
Ficha 10 - Período/ano de publicação: Aproximadamente 1994.

Observações: Não consta a avenida que liga a avenida da barreira do Altiplano ao Bairro dos Bancários e Timbó, nem a avenida que liga ao conjunto Quadramares. Ainda consta a SUNAB que foi extinta em 24 de julho de 1997.

Breve descrição: Folder dobrável com um mapa de parte da cidade de João Pessoa em um dos lados. Do outro lado consta uma legenda com os pontos turísticos numerados e uma lista de telefones úteis.

Tipo de suporte: (folder, encarte, para parede, etc): Folder.

Título do Folder: Mapa turístico de João Pessoa

Título do mapa: Não consta.

Ponto de vista do observador (ou usuário do mapa):: Perspectiva de visão: vertical.

Planta de parte da cidade.

Foto da capa: Fotografia aérea de Picãozinho. Fotógrafo: Tadeu Lubambo.

Escala: Não consta.

Rosa dos ventos: Sim.

Os limites representados (as bordas do espaço representado): Na borda inferior (leste): o limite é a faixa costeira com as praias, desde a praia do Bessa até a praia da Penha. Na borda lateral esquerda (Sul): o limite é a estrada da Penha, o contorno de Mangabeira, O Bairro do José Américo até o contorno da entrada do bairro do Geisel. Na borda superior (oeste): estão no limite os bairros do Cristo, Cruz das Armas e o rio Sanhauá. Na borda lateral (sul): neste limite estão o bairro do Roger, a Avenida Tancredo Neves e o bairro do Bessa.

Público Alvo: Turistas em geral.

Slogans e/ou frases de efeito: "Ponto extremo oriental das Américas".

Principais pontos ou locais destacados: Picãozinho.

Topônimos citados: Ruas e avenidas: Av Cruz das Armas, Rua das Trincheiras, Av Vasco da Gama, Av João Machado, Av Pedro II, Av D. Pedro I, Av Rui Barbosa, Av Beira Rio, Av Tancredo Neves, Av José Américo de Almeida, Av Cabo Branco, Av Tamandaré, Av João Maurício, Av Argemiro de Figueiredo, Av Flaviano R. Coutinho, Av Edson Ramalho, Av dos Navegantes, Av Epitácio Pessoa, Av Rui Carneiro, Estrada da Penha, Av João Rodrigues Alves, BR 230, Av Vasco da Gama. Bairros: Jaguaribe, Centro, Roger, Treze de Maio, Mandacaru, Ipês, Bairro dos Estados, Tambauzinho, Expedicionários, Castelo Branco, Torre, Pedro Gondim, Miramar, Altiplano, Manaíra, Tambaú, Bessa, Bancários, José Américo, Cristo Redentor, Jaguaribe, Rios: Sanhauá. Praias: Praia da Penha, Ponta do Seixas, Ponta do Cabo Branco, Praia do Cabo Branco, Praia de Tambaú, Praia de Manaíra, Praia do Bessa. Setas indicativas para: Cabedelo, Areia Vermelha, Jacaré, Valentina, Mangabeira, Geisel, Maceió, Recife, Tambaba, Natal, Campina Grande, Aeroporto. Outros: Mata do Buraquinho.

Instituição responsável por propor ou encomendar o mapa: Prefeitura Municipal de João Pessoa.

Empresa responsável pela execução do projeto, impressão do mapa: Layout Design - Design Kiyotani

Prefeito da época: Nenhuma pista que indique qual o gestor da época deste mapa.

Autor do mapa: Não identificado. 


\section{Ficha 11}

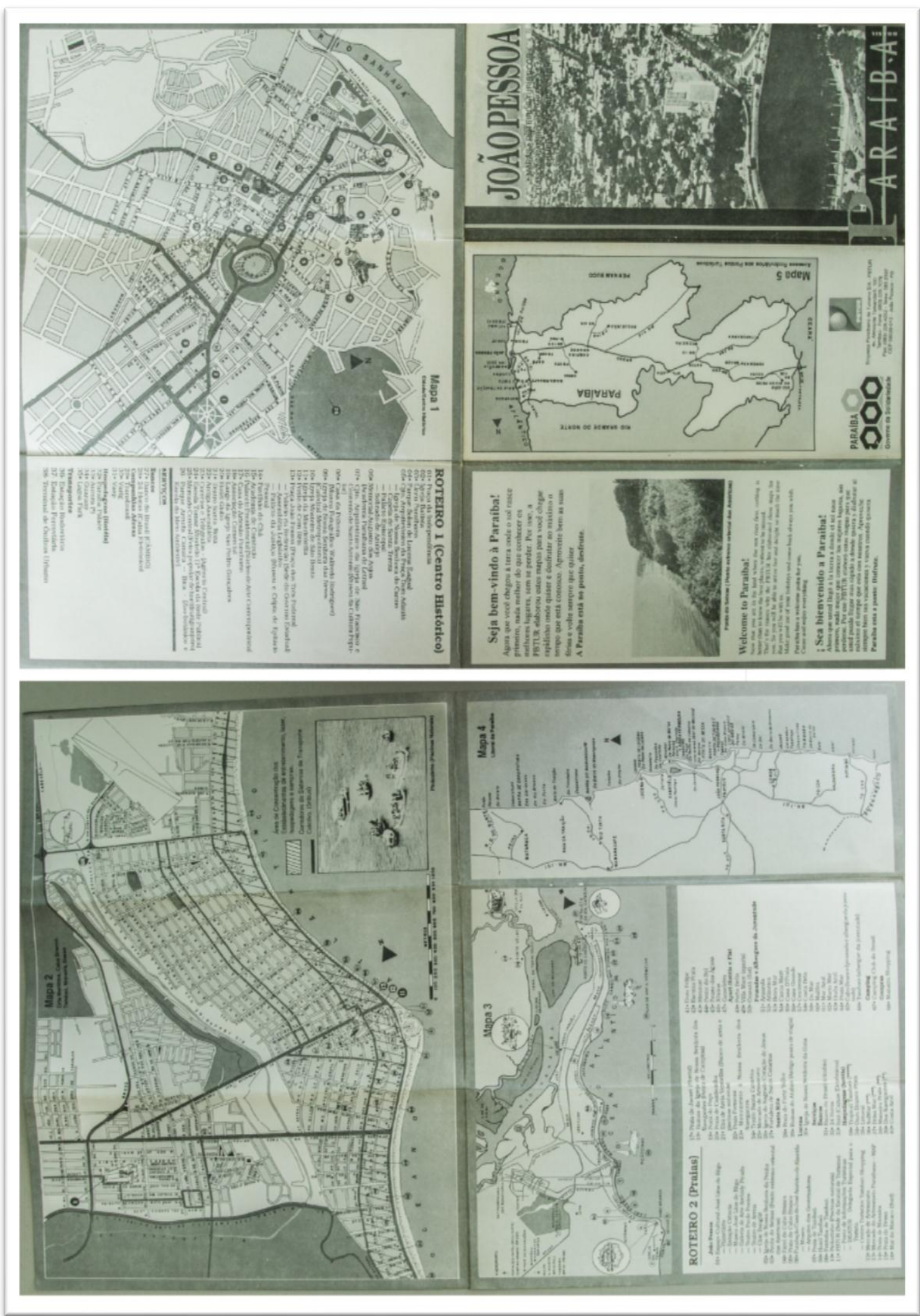

Mapa-Ficha 11 - Folder turístico com vários mapas. Título do Folder: João Pessoa Paraíba - Brasil. Data: 1995. 
Ficha 11- Período/ano de publicação: Ano: 1995

Breve descrição: Mapa institucional em formato de folder dobrável, em preto e branco, ausente de publicidade comercial. Neste mapa se repete a dualidade de setores turísticos na cidade, o centro e a orla marítima, representado pelo Setor 1 - Centro Histórico e Setor 2 - Praias. Destaque principal a Lagoa do Parque Solon de Lucena.

O folder apresenta 5 mapas: Mapa 1 - Cidade/Centro histórico. Mapa 2 - Orla marítima, Cabo Branco, Tambaú, Manaíra, Bessa. Mapa 3 - Praias. Mapa 4 - Litoral da Paraíba. Mapa 5 - Acessos rodoviários aos pontos turísticos do Estado.

Tipo de suporte (folder, encarte, para parede, etc): Folder

Título do folder: JOÃO PESSOA - PARAÍBA - BRASIL.

Título dos mapas:

Mapa 1 - Cidade/Centro histórico.

Mapa 2 - Orla marítima, Cabo Branco, Tambaú, Manaíra, Bessa.

Mapa 3 - Praias.

Mapa 4 - Litoral da Paraíba.

Mapa 5 - Acessos rodoviários aos pontos turísticos do Estado.

Ponto de vista do observador (ou usuário do mapa): Vista vertical característica de planta urbana.

Foto da capa: Fotografia aérea panorâmica em preto e branco, visão tomada da Lagoa do Parque Solon de Lucena em direção ao mar.

Escala: Apresenta Escala Gráfica

Rosa dos ventos: Apresenta a indicação do Norte

Os limites representados (as bordas do espaço representado):

Mapa 1 - limita o espaço da cidade que compreende a área conhecida como o centro da cidade. A leste tem limite na Pça da Independência, a oeste tem o rio Sanhauá como limite, a norte o Centro Histórico e o Parque Arruda Câmara (A Bica) e ao sul o limite é o bairro de Jaguaribe.

Mapa 2 - Ao sul o limite é a praia de Manaíra, ao norte tem o limite na praia de Tambaú, a leste o limite é o mar e, tomando uma linha reta de leste para oeste o mapa representa cerca de $2 \mathrm{Km}$.

Mapa 3 - Representa a faixa do litoral da Grande João Pessoa, tendo ao sul o município de Cabedelo e a praia de Lucena, ao norte nas bordas do mapa vê-se a praia da Penha, A leste tem-se o mar como limite e a oeste o estuário do rio Sanhauá.

Mapa 4 - O mapa 4 ilustra todo o litoral do Estado. Na borda norte o limite do estado do Rio Grande do Norte, no lado sul o limite é o estado de Pernambuco, A leste tem-se o mar e a oeste na borda está a BR 101.

Mapa 5 - Este mapa representa o Estado da Paraíba até os limites dos estados vizinhos.

Público alvo: Turistas em geral.

Slogans e/ou frases de efeito: "A Paraíba está no ponto, desfrute".

"Ponta do Seixas (ponto extremo oriental das Américas)".

"Paraíba - Governo da Solidariedade"

Principais pontos ou locais destacados: Picãozinho (Piscinas naturais) - apresenta fotografia em destaque.

Instituição responsável por propor ou encomendar o mapa: Governo do Estado / PBTUR

Empresa responsável pela execução do projeto, impressão do mapa: Não identificada. Governador da época: Antônio Marques da Silva Mariz

Autor do mapa: Não identificado.

Ficha 12 

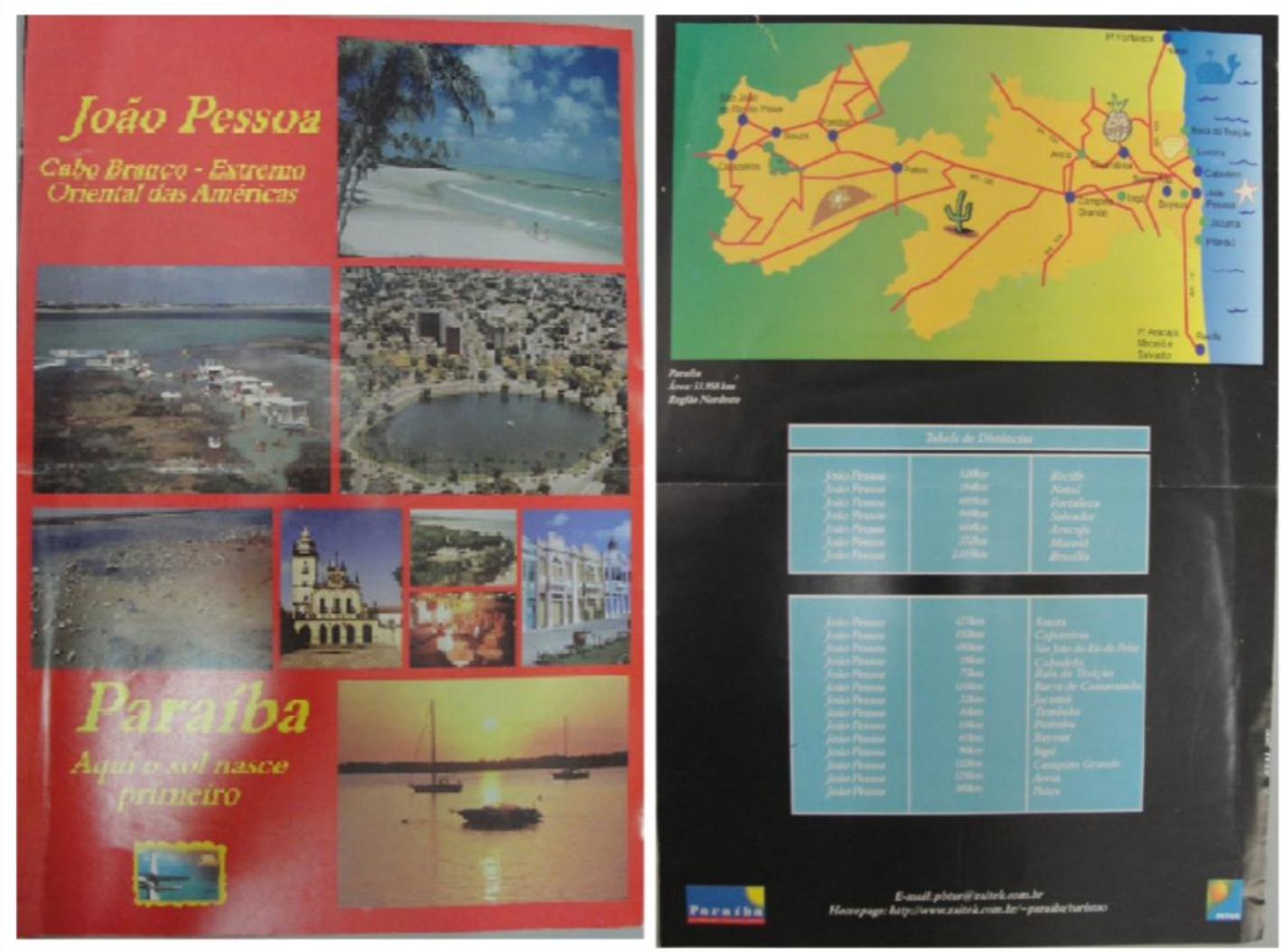

Mapa-Ficha 12 - Material publicitário turístico com um mapa do Estado da Paraíba 
Ficha 12 - Período/Ano de publicação: 1996 aproximadamente

Breve descrição: Folder institucional. Consta mapa da Paraíba sem escala nem legenda, com as principais cidades do Estado e com o litoral. Consta tabela de distâncias entre João Pessoa e outras cidades.

Tipo de suporte: (folder, encarte, para parede, etc): Folder.

Título do folder: JOÃO PESSOA - Cabo Branco - Extremo oriental das Américas

Título do mapa: Não consta.

Ponto de vista do observador (ou usuário do mapa): Visão vertical.

Foto da capa: Capa com várias fotografias de lugares turísticos: praias, Areia Vermelha, Picãozinho, Lagoa do Parque Solon de Lucena, Centro Histórico, Igreja de São Francisco, Quadrilhas, Farol do Cabo Branco.

Escala: Não consta

Rosa dos ventos: não consta

Os limites representados (as bordas do espaço representado): O estado da Paraíba Público Alvo: Turistas em geral

Slogans e/ou frases de efeito: "Extremo oriental das Américas". "Paraíba: Aqui o sol nasce primeiro". "Austeridade é desenvolvimento".

Principais pontos ou locais destacados:

Topônimos citados: Nomes das principais cidades do estado, bem como todas as cidades do litoral.

Instituição responsável por propor ou encomendar o mapa: Governo do Estado Empresa responsável pela execução do projeto, impressão do mapa: Real 2000 Governador da época: José Targino Maranhão Autor do mapa: Não identificado. 


\section{Ficha 13}

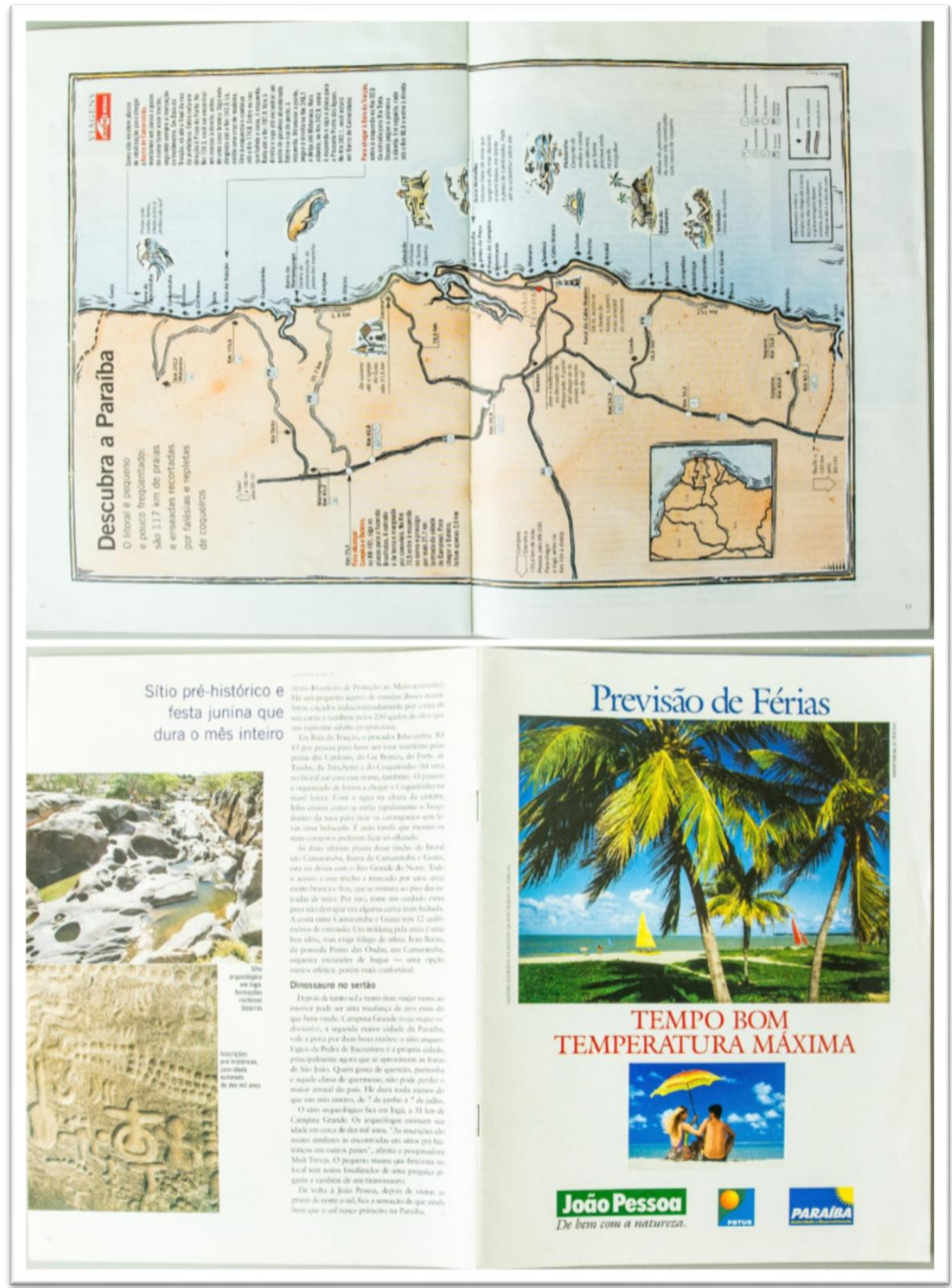

Mapa-Ficha 13 - Mapa do litoral da Paraíba. Encarte da revista Quatro Rodas. Data: 1996. 
Ficha 13 - Período/Ano de publicação:1996.

Breve descrição: Encarte dobrável ao meio com um mapa do litoral da Paraíba em um dos lados. Material extraído da revista Quatro Rodas de maio de 1996. Consta logomarcas do Governo do Estado da Paraíba e da PBTUR.

Tipo de suporte (folder, encarte, para parede, etc): Encarte da revista Quatro Rodas de maio de 1996.

Título dofolder: Previsão de Férias - Tempo Bom, Temperatura Máxima

Título do mapa: Descubra a Paraíba.

Ponto de vista do observador (ou usuário do mapa): Vista vertical.

Foto da capa: Foto principal: tirada entre os coqueiros da praia de Tambaú com vista ao longe da Ponta do Cabo Branco. Foto menor: casal na beira mar sentado sob um guarda sol.

Escala: Não consta

Rosa dos ventos: Não consta.

Os limites representados (as bordas do espaço representado):

No sentido Leste-Oeste, representa a faixa do litoral do estado partindo do oceano até a BR 101.

No sentido Sul norte, representa as praias da faixa litorânea desde A praia de Acaú no município de Pitimbu, na divisa com Pernambuco, até a praia de Guajú, próximo à divisa com o Rio Grande do Norte.

Público Alvo: Leitores da Revista Quatro Rodas.

Slogans e/ou frases de efeito: "Tempo Bom, Temperatura Máxima"

Principais pontos ou locais destacados: Alguns pontos têm destaque com ícones/desenhos como a Igreja da Guia (em Lucena), Tambaba (Praia de naturismo), Barra de Gramame, Picãozinho, Praia do Seixas, o Farol do Cabo Branco, Areia Vermelha, A Fortaleza de Santa Catarina, A Barra de Mamanguape e a Barra de Camaratuba.

Topônimos citados: Todas as praias do litoral da Paraíba. Cidades: Caaporã, Taquara, Conde, Bayeux, Lucena, Mamanguape, Rio Tinto, Mataraca. Praias: Tambaba, Barra de Gramame, Picãozinho, Areia Vermelha, Barra de Camaratuba.

Instituição responsável por propor ou encomendar o mapa: Consta logomarcas do Governo do Estado da Paraíba e da PBTUR / Material extraído da revista Quatro Rodas de maio de 1996.

Empresa responsável pela execução do projeto, impressão do mapa: Oficina de Propaganda

Governador da época: José Targino Maranhão

Autor do mapa: Não identificado. 


\section{Ficha 14}

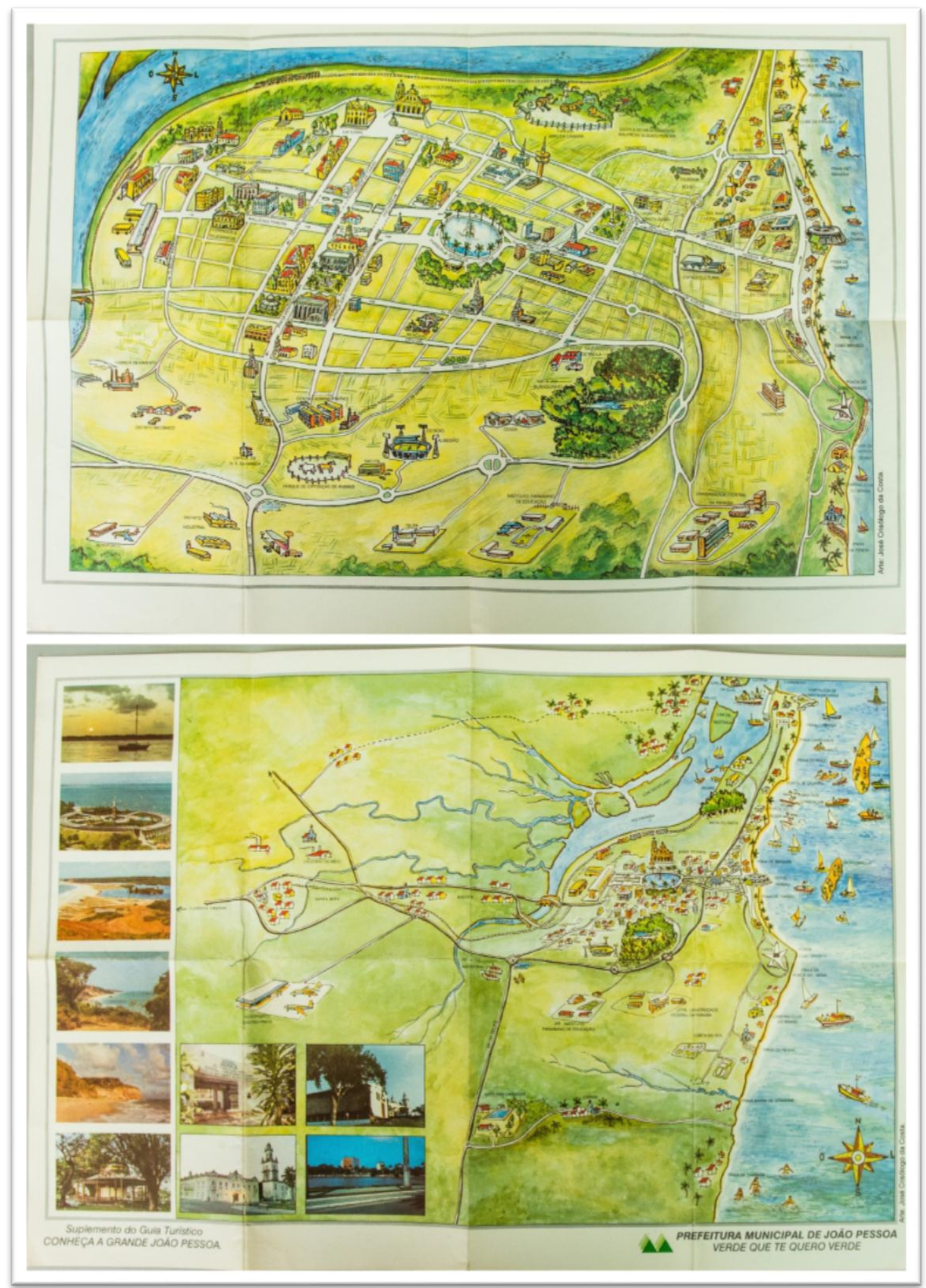

Mapa-Ficha 14 - Mapa "Conheça a Grande João Pessoa". Material pertencente à publicação "Guia Turístico Conheça a Grande João Pessoa". Data: Período aproximado 1997-1998. 
Ficha 14 - Período/ano de publicação: Data aproximada do mapa 1997-1998 (Consta no mapa a SAELPA que foi privatizada e mudou de nome em 2000, e a TELPA, que funcionou com este nome até 1998).

Breve descrição: Encarte da publicação "Guia Turístico: Conheça a Grande João Pessoa". Encarte dobrado ao meio. Apresenta a referência da Prefeitura Municipal de João Pessoa, mas sem logomarca, nem nada que indique a época do mapa. Em cada lado existe um mapa.

O primeiro mapa que será considerado o mapa principal (aquele que tem um título e está no lado do encarte em que constam informações) representa uma área bem extensa, englobando desde a cidade de Lucena (ao norte) até a praia de Tambaba (ao sul), incluindo também as cidades de Santa Rita e Bayeux que raramente aparecem nos mapas turísticos estudados.

No segundo mapa, localizado no lado oposto do encarte, a área representada fica mais restrita, destacando ao centro do mapa a Lagoa do Parque Solon de Lucena, a área representada inicia no bairro do Bessa (ao norte) até a praia da Penha (ao sul), o Distrito Industrial, o bairro do Varadouro e o bairro do Róger.

Tipo de suporte (folder, encarte, para parede, etc): Encarte

Título do Encarte: Conheça a Grande João Pessoa (Suplemento do Guia Turístico)

Título do mapa: Conheça a Grande João Pessoa

Ponto de vista do observador (ou usuário do mapa): De sul para norte

Foto da capa: Não apresenta capa.

Escala: Não consta.

Rosa dos ventos: Sim.

Os limites representados (as bordas do espaço representado): $\mathrm{O}$ primeiro mapa: os limites da borda superior (norte) são as cidades de Lucena e Cabedelo e a Igreja da Guia. $\mathrm{Na}$ borda inferior (sul) está a praia de Tambaba. Na borda Lateral direita (leste) está a faixa costeira com as praias. Na borda lateral esquerda (oeste) o limite é o município de Santa Rita. O segundo mapa: os limites da borda superior (norte) são a Ponta do Bessa e o Mar dos Macacos, o Parque Arruda Câmara e a Igreja de São Francisco. Os limites da borda inferior (sul) são a Praia da Penha, a UFPB e o Distrito Industrial. Na borda lateral direita (leste) está a faixa costeira com as praias. Na borda lateral esquerda (oeste) está o bairro do varadouro, as estações rodoviária e ferroviária, a Fábrica de Cimento e o Distrito dos mecânicos.

Público Alvo: Turistas em geral.

Slogans e/ou frases de efeito: "Verde que te quero Verde"

Topônimos citados:

No primeiro mapa: Igreja da Guia, Forte Velho, Forte de Santa Catarina, Camping Clube do Brasil, Hotel Tambaú, Mata do Amém, UFPB (Universidade Federal da Paraíba), Costa do sol, Vale das Cascatas, IPÊ (Instituto Paraibano de Educação), BR 101 (Recife), Mata do Buraquinho, Aeroporto Castro Pinto, Engenho do Meio, Distrito Industrial, Ilhas: Areia Vermelha, Ilha da Restinga, Ilha do Stuart,

Municípios: Cabedelo, Lucena, Conde, Bayeux, Santa Rita, Campina Grande, Natal. 
Praias: Formosa, Camboinha, Poço, Ponta de Campina, Mar dos Macacos, Jacaré, Bessa, Manaíra, Tambaú, Ponta do Cabo Branco, Ponta do Seixas, Penha, Barra de Gramame, Tambaba.

Rios: Paraíba e Sanhauá.

No segundo mapa: Escola do Meio Ambiente Walfredo Guedes Pereira, Parque Arruda Câmara, Fazenda Boi Só, Hospital Santa Isabel, Iate Clube da Paraíba, Ponta do Cabo Branco, Camping Clube da Paraíba, Universidade Federal da Paraíba, Instituto Paraibano de Educação, Nazareno, Fundação Casa de José Américo, Clube Cabo Branco, Espaço Cultural, Centro Turístico, Elite Bar e Restaurante, Shopping Manaíra, Sol Mar Hotel, Hospital São Vicente de Paula, Mata do Buraquinho, CEASA, Estádio Almeidão, TELPA, SAELPA, Igreja do Rosário, Parque Solon de Lucena, Centro Cultural São Francisco, Catedral, Casa da Pólvora, Igreja São Pedro Gonçalves, Hotel Globo, TV o Norte, Capela Nossa Senhora das Graças, Distrito Industrial, Distrito dos Mecânicos, Fábrica de Cimento, Aeroporto, estação ferroviária, estação rodoviária,

Praias: Mar dos Macacos, Ponta do Bessa, Manaíra, Tambaú, Cabo Branco, Ponta do Seixas, Penha.

Praças: Venâncio Neiva, João Pessoa, Praça 1817, Praça da Independência,

Ruas e Avenidas: Av. Argemiro de Figueiredo, Av. Flávio R. Coutinho, Av. Senador Rui Carneiro, Av. Presidente Epitácio Pessoa, Av. José Américo de Almeida (Beira Rio), Av. Nossa Senhora de Fátima, Via Expressa Tancredo Neves, Av. Panorâmica, BR 230, BR 101, Av Pedro II, Av. João Machado, Av. Camilo de Hollanda, Av. Maximiniano Figueiredo, Av. Getúlio Vargas, Rua Mons. Walfredo Leal, Av. Getúlio Vargas, Rua Odon Bezerra, Rua Visconde de Pelotas, Av. Duque de Caxias, Rua General Osório, Rua Guedes Pereira, Av. Vasco da Gama, Rua Maciel Pinheiro,

Instituição responsável por propor ou encomendar o mapa: Prefeitura Municipal de João Pessoa

Empresa responsável pela execução do projeto, impressão do mapa: Não identificada.

Prefeito da época: Cícero Lucena.

Autor do mapa: Arte: José Crisólogo da Costa 


\section{Ficha 15}
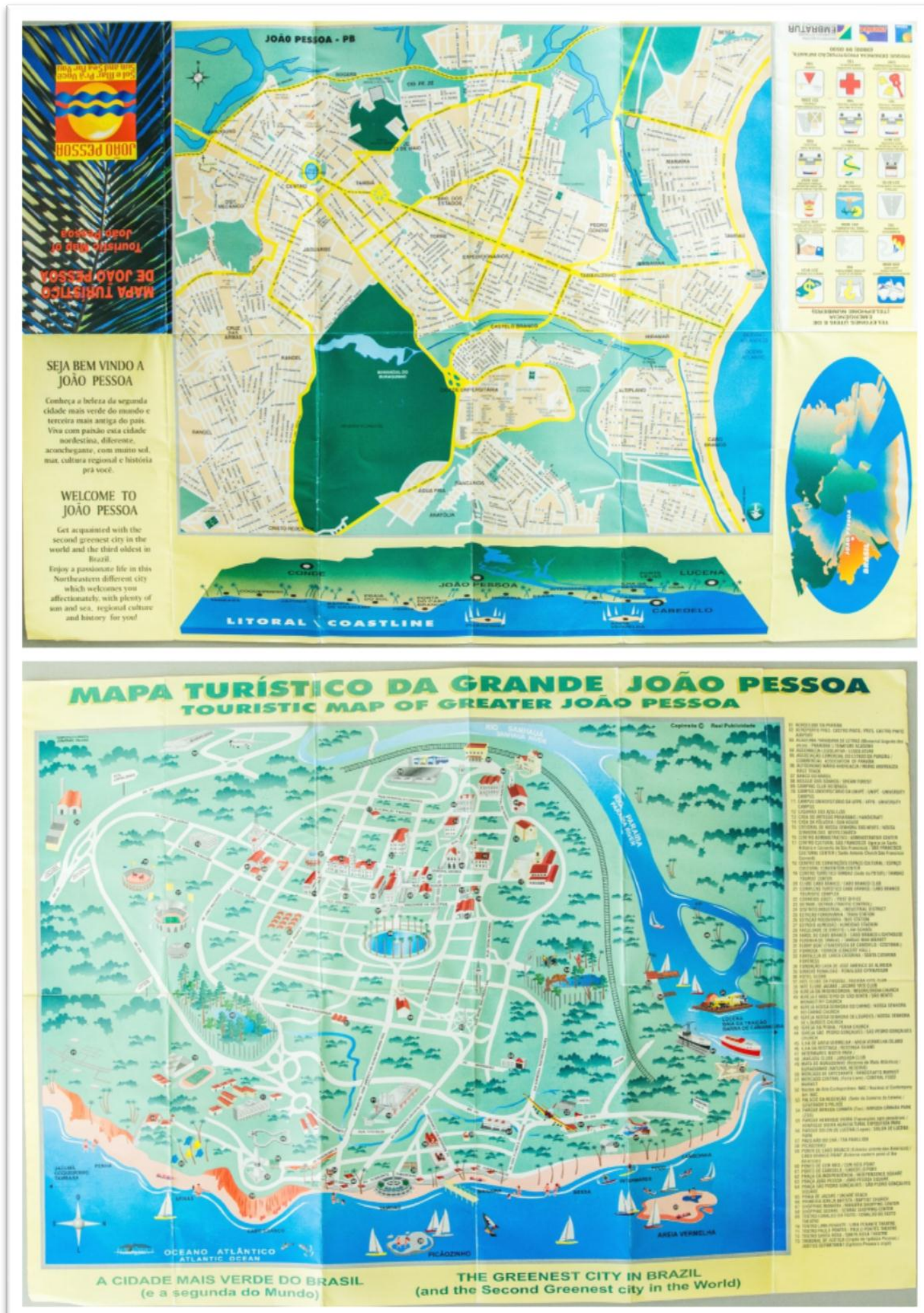

Mapa-Ficha 15 - Mapa turístico da grande João Pessoa.

Data: período de 1998 a 1999. 
Ficha 15 - Período/Ano de publicação: Data aproximada 1998 a 1999.

Observação: os indícios são a presença do Intermares Water Park que encerrou as atividades no ano de 2000.

Breve descrição: Folder com dois mapas. O primeiro é um mapa pictórico, sem escala, com detalhes das praias e pontos turísticos. Os pontos turísticos são numerados indexados no mapa e listados em ordem alfabética do lado direito do mapa. Apresenta partes do texto em inglês.

O segundo mapa é derivado dos mapas das listas telefônicas e apresenta a nomenclatura Tipo de suporte: (folder, encarte, para parede, etc): Folder

Título do Folder: Mapa Turístico de João Pessoa - Touristic map of João Pessoa.

Título do Mapa: Mapa Turístico da Grande João Pessoa - Touristic map of greater João Pessoa.

Ponto de vista do observador (ou usuário do mapa): O primeiro mapa apresenta perspectiva de Leste para Oeste. O segundo mapa apresenta vista vertical da cidade e das ruas.

Foto da capa: Foto de uma palha de coqueiro

Escala: Não consta.

Rosa dos ventos: $\operatorname{sim}$

Os limites representados (as bordas do espaço representado):

O primeiro mapa: no lado leste apresenta todo o litoral da cidade, parte da Foz do Rio

Paraíba até a praia da Penha. Contornando pelo lado sul tem a $\mathrm{Br} 230$ e o Distrito industrial. A borda oeste do mapa apresenta o Rio Sanhauá e a borda norte é toda contornada pelo rio Paraíba.

O segundo mapa: é uma planta urbana utilizada comumente pela LISTEL nas listas telefônicas distribuídas anteriormente. A borda direita do mapa diz respeito à área litorânea da cidade que vai do bairro do Bessa até o Cabo Branco. Na parte inferior do mapa visualizamos os bairros dos Bancários, Anatólia, Água Fria e o Cristo Redentor, além da mata do Buraquinho. No lado esquerdo (oeste da cidade) visualizamos o bairro do Rangel, Distrito dos mecânicos. E no lado superior do mapa (norte da cidade) visualizamos o Padre Zé, Rogers e a Bica.

Público alvo: Turistas nacionais e internacionais.

Slogans e/ou frases de efeito:

"A CIDADE MAIS VERDE DO BRASIL, e a segunda do mundo"

"... terceira mais antiga do país".

"Viva com paixão esta cidade nordestina, diferente, aconchegante, com muito sol, mar, cultura regional e muito sol prá você".

Topônimos citados: O primeiro mapa apresenta as Principais avenidas, as praias, os pontos turísticos: Picãozinho e Areia Vermelha e os rios Paraíba e Sanhauá.

Instituição responsável por propor ou encomendar o mapa: Governo do Estado / PBTUR

Empresa responsável pela execução do projeto, impressão do mapa: Real Publicidade Governador da época: José Targino Maranhão (1995 - 1999) (Reeleito: 1999 - 2002)

Autor do mapa: Responsável pela reprodução em computação gráfica: Jonathas Falcão 


\section{Ficha 16}

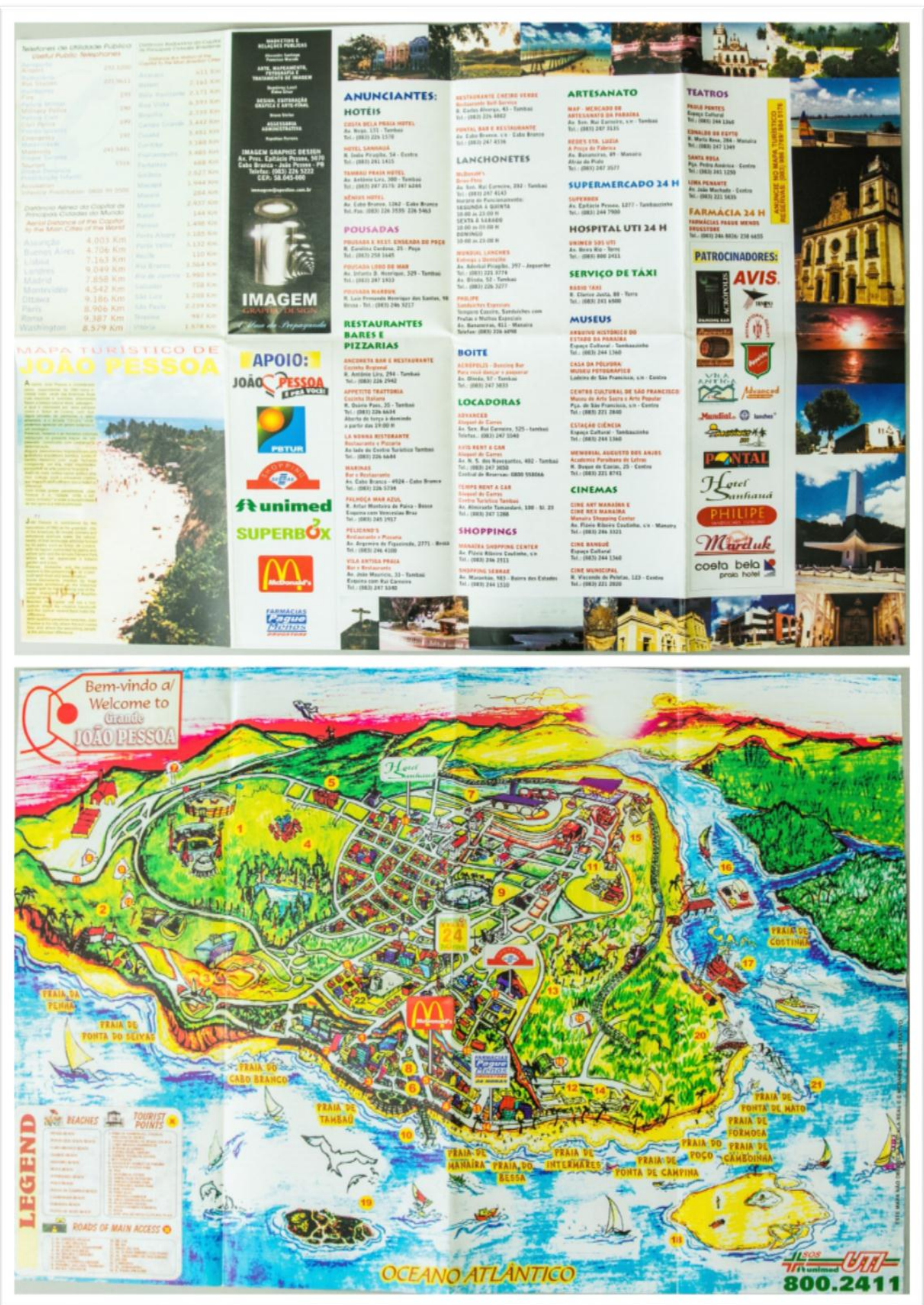

Mapa-Ficha 16 - Mapa Turístico de João Pessoa. Data: 1998. 
Ficha 16 - Período/ano de publicação: Aproximadamente 1998

Breve descrição: Folder dobrável, com uma capa onde aparece a foto da praia do Seixas. Diversas empresas aparecem representadas em seus respectivos endereços através de suas marcas. Empresas: MacDonalds, Supermercados Superbox, Hotel Sanhauá, Farmácias Pague Menos, SOS UTI Unimed, Shopping Sebrae. Apresenta legenda em inglês.

Tipo de suporte (folder, encarte, para parede, etc): Folder mapa dobrável.

Título do folder: $\mathrm{O}$ folder apresenta o título: Mapa turístico de João Pessoa.

Título do mapa: O mapa não apresenta um título de forma direta, consta uma "etiqueta" como a frase: "Bem-vindo à/Welcome to Grande João Pessoa".

Ponto de vista do observador (ou usuário do map): Perspectiva de visão com sentido de Leste para Oeste

Foto da capa: Foto da praia de Ponta de Seixas vista de cima da Barreira do Cabo

Escala: Não consta.

Rosa dos ventos: Não consta.

Os limites representados (as bordas do espaço representado):

Na borda direita do mapa (norte) o limite é o município de Cabedelo.

Na borda do lado esquerdo (Sul) está a praia da Penha e mais acima as proximidades do Distrito Industrial.

$\mathrm{Na}$ borda inferior (leste) o limite é a faixa costeira e as praias.

$\mathrm{Na}$ borda superior, oeste e a noroeste do mapa o rio Sanhauá é o limite.

Público Alvo: Turistas estrangeiros.

Slogans e/ou frases de efeito: “... a cidade mais verde das Américas”. "... a cidade onde o sol nasce primeiro"

Principais pontos ou locais destacados: MacDonalds, Supermercados Superbox, Hotel Sanhauá, Farmácias Pague Menos, SOS UTI Unimed, Shopping Sebrae.

Topônimos citados: Praias: Costinha, Ponta de Mato, Formosa, Camboinha, Poço, Ponta de Campina, Intermares, Bessa, Manaíra, Tambaú, Cabo Branco, Penha.

Instituição responsável por propor ou encomendar o mapa: Prefeitura Municipal de João Pessoa.

Empresa responsável pela execução do projeto, impressão do mapa: Imagem Graphic Design.

Prefeito da época: Cícero Lucena Filho

Autor do mapa: Demetrius Lacet e Eldno César. 


\section{Ficha 17}

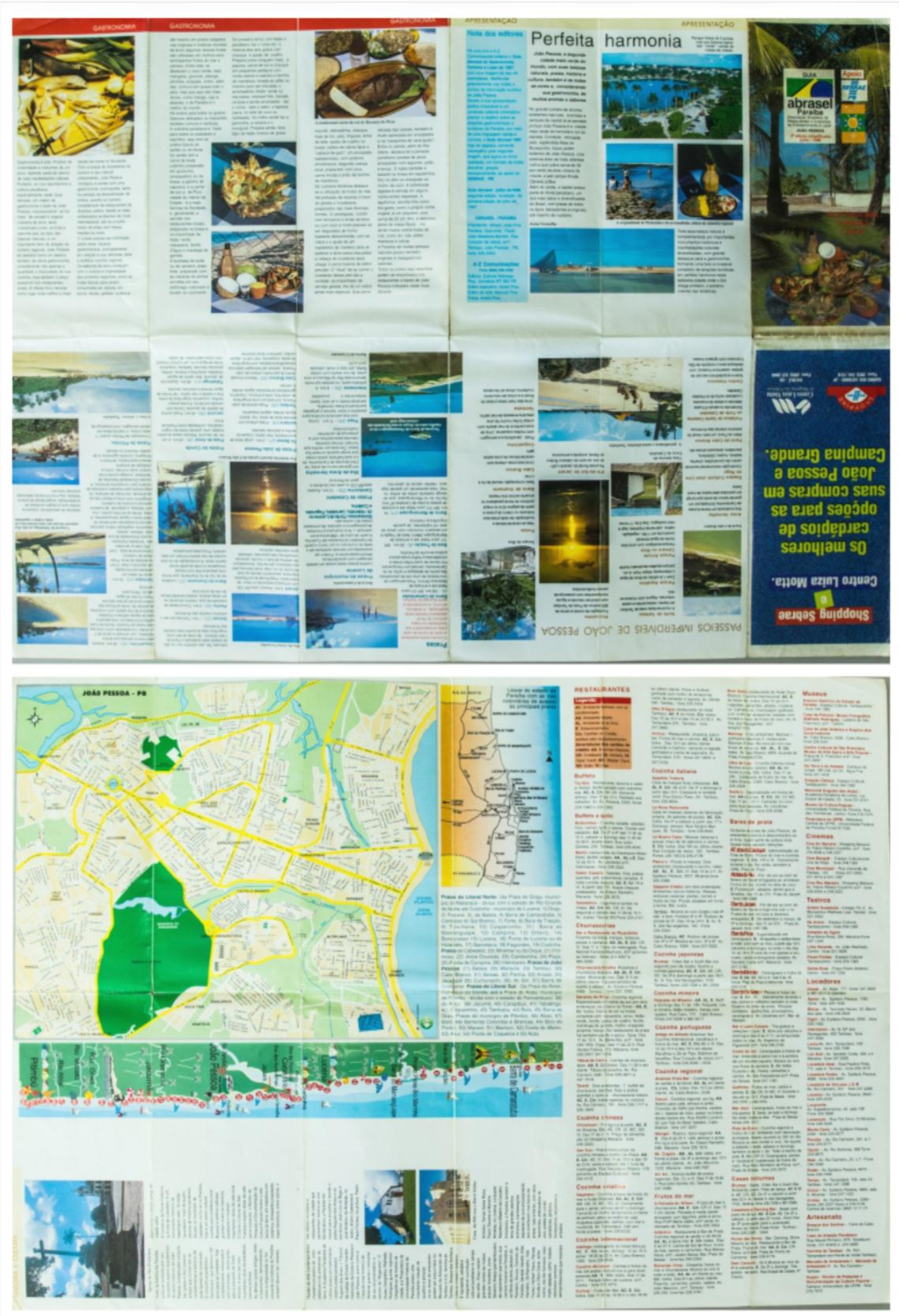

Mapa-Ficha 17 - Material de divulgação turística em formato de folder com temática gastronômica. Apresenta mapas da cidade de João Pessoa e do Estado. Data: 1998. 
Ficha 17 - Período/ano da publicação: Ano de 1998

Breve descrição: Folder dobrável de divulgação turística. Depois de aberto verificam-se nos dois lados informações diversas. Num dos lados do folder constam dois mapas, um de parte da cidade de João Pessoa e outro, de tamanho menor, do litoral do Estado, além de informações e endereços de vários restaurantes. No lado oposto dos mapas aparecem várias fotografias de praias, lugares turísticos e pratos culinários, além de texto com breve descrição de passeios e locais de visitação como praias, Centro Histórico, Bica, Espaço Cultural, Areia Vermelha, Pôr do Sol do Jacaré, entre outros.

Tipo de suporte (folder, encarte, para parede, etc): Folder.

Título do folder: Gastronomia Turismo e Lazer

Título do mapa: Não consta.

Ponto de vista do observador (usuário do mapas): Vista vertical característica de planta urbana.

Foto da capa: Mesa com pratos de frutos do mar posta num jardim à beira mar.

Escala: Não consta

Rosa dos ventos: $\mathrm{Sim}$

Os limites representados (as bordas do espaço representado):

Borda superior do mapa (norte da cidade) os limites são o Rio Paraíba, os Bairros do Roger e Padre Zé, e o Bairro do Bessa.

Borda Lateral direita (leste) está a faixa litorânea com as praias do Bessa, Tambaú e Cabo Branco.

Os limites da borda inferior do mapa (sul da cidade) estão os bairros dos Bancários, Anatólia, Água Fria, Cristo, o Estádio Almeidão e a Mata do Buraquinho.

$\mathrm{Na}$ borda lateral esquerda do mapa (oeste) estão os bairros do Rangel, Cruz das Armas, Distrito dos mecânicos e Varadouro.

Público alvo: Turistas em geral.

Slogans e/ou frases de efeito: "Segunda cidade mais verde do mundo".

Principais pontos ou locais destacados:

Topônimos citados: Bairros e ruas, as praias do Bessa, Tambaú e Cabo Branco. A Mata do Buraquinho. A Lagoa do Parque Solón de Lucena e o Hotel Tambaú.

Instituição responsável por propor ou encomendar o mapa: ABRASEL (Associação Brasileira de Restaurantes e Empresas de Entretenimento e Lazer), com apoio do SEBRAE-PB.

Empresa responsável pela execução do projeto, impressão do mapa: A-Z Comunicações.

Governador da época: José Targino Maranhão [1995 - 1999] [1999 - 2002 - reeleito]

Autor do mapa: Não identificado. 
Ficha 18

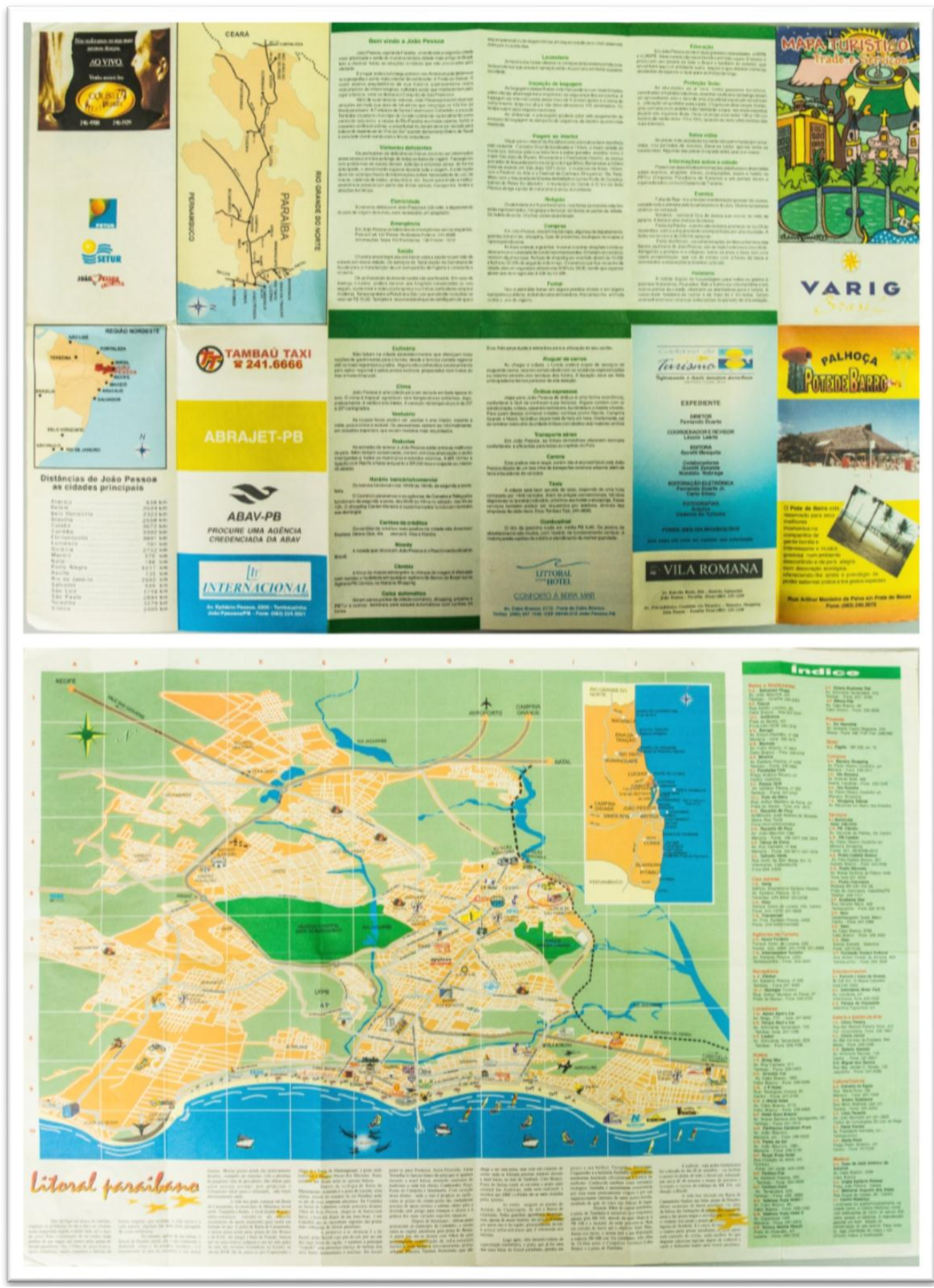

Mapa-Ficha 18 - Mapa na forma de folder de divulgação turística com muitas propagandas, apesar de ser da Prefeitura Municipal. Data: 1998. 
Ficha 18 - Período/ano de publicação: Ano de 1998.

Observações: o folder não apresenta data de publicação e esta informação foi identificada através da presença da logomarca indicativa do Governo Municipal: Coração e slogan: "É prá você" que identifica o governo municipal de Cícero Lucena. O folder apresenta também uma arte de Clóvis Jr. datada de 1998. Outra informação que indica o ano de publicação são os números de telefones com 3 dígitos iniciais e a ausência total de números de celulares. Além disso tem a presença do Intermares Water Park que encerrou as atividades no ano de 2000.

Breve descrição: Folder institucional, dobrável de divulgação turística. Apresenta conteúdo informativo nos dois lados. Em um dos lados existe um mapa da cidade. No lado superior direito deste mapa consta, em detalhe, um mapa menor representando o litoral da Paraíba. Neste mesmo lado do folder, como se fosse uma borda localizada na parte inferior do mapa, existe um texto de apresentação das praias de todo o litoral da Paraíba. Apesar de ser um material turístico institucional com a logomarca da Prefeitura municipal e da Secretaria de Turismo, tem um conteúdo publicitário muito grande, com as logomarcas de empresas dispostas no mapa indicando a localização das mesmas por toda cidade.

Tipo de suporte (folder, encarte, para parede, etc): Folder institucional com muitas publicidades de empresas privadas.

Título do Folder: Mapa Turístico - Trade e Serviços

Título do Mapa: Não apresenta um título

Ponto de vista do observador (ou usuário do mapa): Perspectiva de visão no sentido de leste para oeste.

Foto da capa: Ilustração do artista plástico Clóvis Júnior.

Escala: Não consta

Rosa dos ventos: $\mathrm{Sim}$

Os limites representados (as bordas do espaço representado): Na borda inferior, do lado leste da cidade, está o litoral iniciando do lado direito pela ponta de Cabedelo indo até a praia da Penha. Os limites da borda esquerda do mapa (sul da cidade) são os bairros de Mangabeira, Geisel e Funcionários. Na borda superior do mapa (oeste) estão o Distrito Industrial e a BR 101 e na extremidade Norte está o Rio Sanhauá e Cabedelo.

Público Alvo: Turistas em geral

Slogans e/ou frases de efeito:

"[...] segunda cidade mais arborizada e verde do mundo"

"[...] é o lugar onde o sol chega primeiro nas Américas..."

"[...] Detém em sua geografia o ponto mais oriental do continente: A Ponta de Seixas".

Topônimos citados: Aparecem apenas alguns bairros e algumas ruas da cidade. Estão nomeados o Farol do Cabo Branco e a Ponta de Seixas, o Campus da UFPB e da UNIPÊ, a Galeria Chico Ferreira, a Galeria Miguel dos Santos, a Galeria Clóvis Júnior, o estádio Almeidão e o Ronaldão, o Rio Jaguaribe, o Centro Histórico, a Igreja de São Francisco, o Parque Arruda Câmara, o Aeroclube, Picãozinho e a Reserva Florestal da Mata do Buraquinho.

Instituição responsável por propor ou encomendar o mapa: Prefeitura Municipal. Empresa responsável pela execução do projeto, impressão do mapa: Caderno de Turismo [8 Anos]. Diretor: Fernando Duarte. Coordenador e Revisor: Léucio Laerte. Editora: Goretti Mesquita. Colaboradores: Goretti Zenaide e Ronaldo Nóbrega. Editoração Eletrônica: Fernando D. Júnior e Carlo Irineu.

Prefeito da época: Cícero Lucena Filho

Autor do mapa: Não identificado. 


\section{Ficha 19}
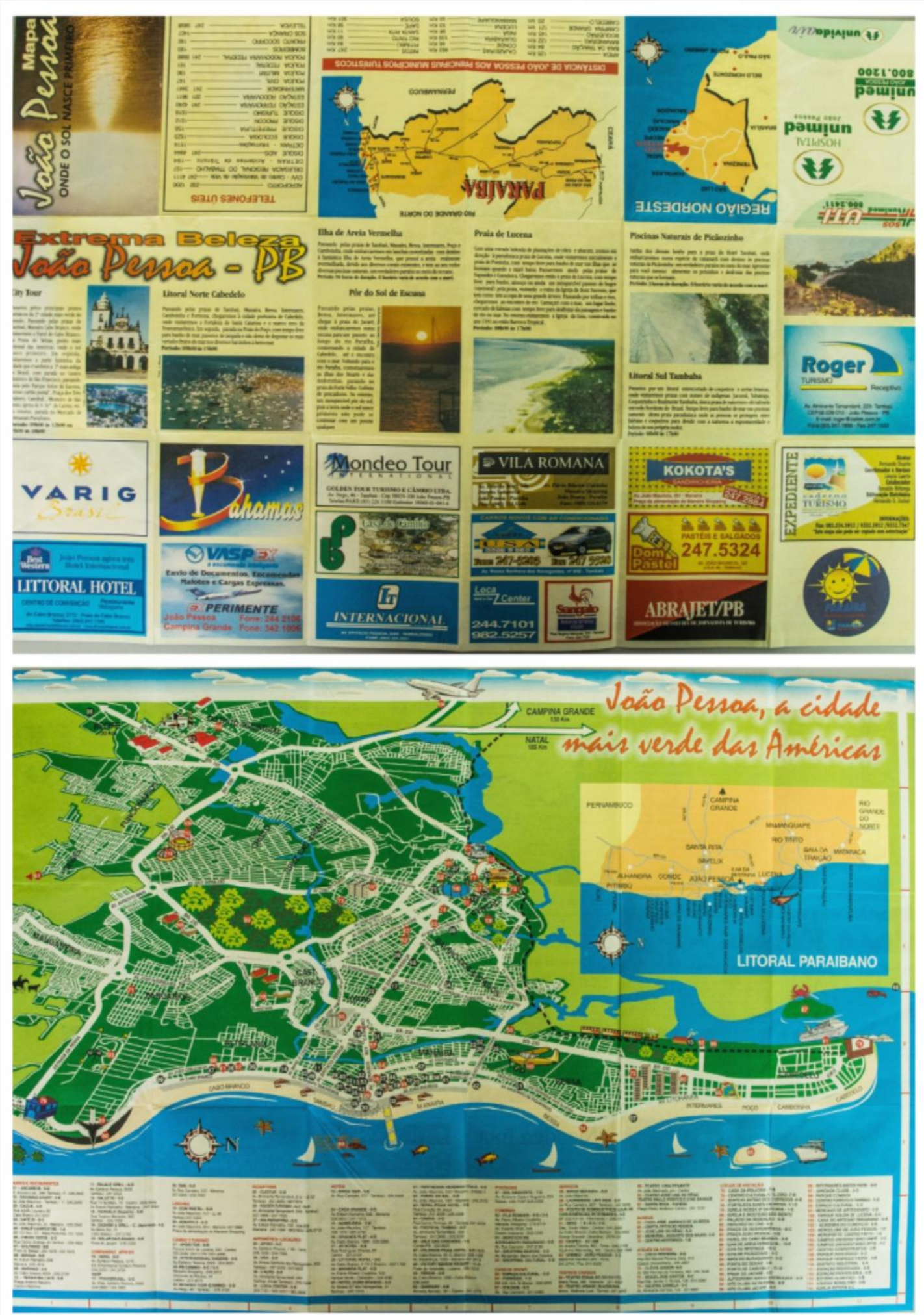

Mapa-Ficha 19 - Mapa turístico: “João Pessoa, a cidade mais verde das Américas”. Data aproximada: 1999. 
Ficha 19 - Período de publicação/Ano: Aproximadamente 1999.

Observação: o que dá indícios desta data é a presença de números de telefones celulares ainda com início contendo 3 dígitos. Números de telefones fixos também com 3 dígitos iniciais indicam o início da década de 2000. O indício mais marcante descoberto é que o Caderno de Turismo em 1998 marcava seu oitavo ano.

Breve descrição: Mapa turístico em formato de folder com forte apelo publicitário, apresentando muitas propagandas no verso. No interior do mapa também estão indexados pontos indicativos de estabelecimentos comerciais e de serviços. Apresenta um mapa em tamanho menor do litoral da Paraíba na parte superior direita.

Suporte (folder, encarte, para parede, etc): Folder

Título do Folder: Mapa João Pessoa - Onde o sol nasce primeiro

Título do Mapa: João Pessoa, a cidade mais verde das Américas.

Ponto de vista do observador (ou usuário do mapa): Perspectiva no sentido de Leste para Oeste.

Foto da capa: O mar com o reflexo dourado do sol nascendo

Escala: Não consta.

Rosa dos ventos: Sim.

Os limites representados (as bordas do espaço representado): Na borda do lado leste está o litoral iniciando do lado direito pela ponta de Cabedelo indo até a praia da Penha. Contornando a borda pelo lado Sul o limite representado pelo mapa é o bairro de Mangabeira. Na borda oeste está o Distrito Industrial e na extremidade oeste o limite do mapa é o Centro Histórico da cidade.

Publico alvo: Turistas, com um forte apelo publicitário

Slogans e/ou frases de efeito: João Pessoa, onde o sol nasce primeiro./ João Pessoa, a cidade mais verde das Américas

Principais pontos ou locais destacados.

Topônimos citados: Nomes das principais avenidas, Bairros e praias.

Instituição responsável por propor ou encomendar o mapa: Governo do Estado

Empresa responsável pela execução do projeto, impressão do mapa: Caderno de Turismo. Diretor: Fernando Duarte. Coordenador e Revisor: Léucio Laerte. Colaborador: Ronaldo Nóbrega. Editoração Eletrônica: Fernando D. Júnior.

Governador da época: José Targino Maranhão.

Autor do mapa: Não identificado. 


\section{Ficha 20}

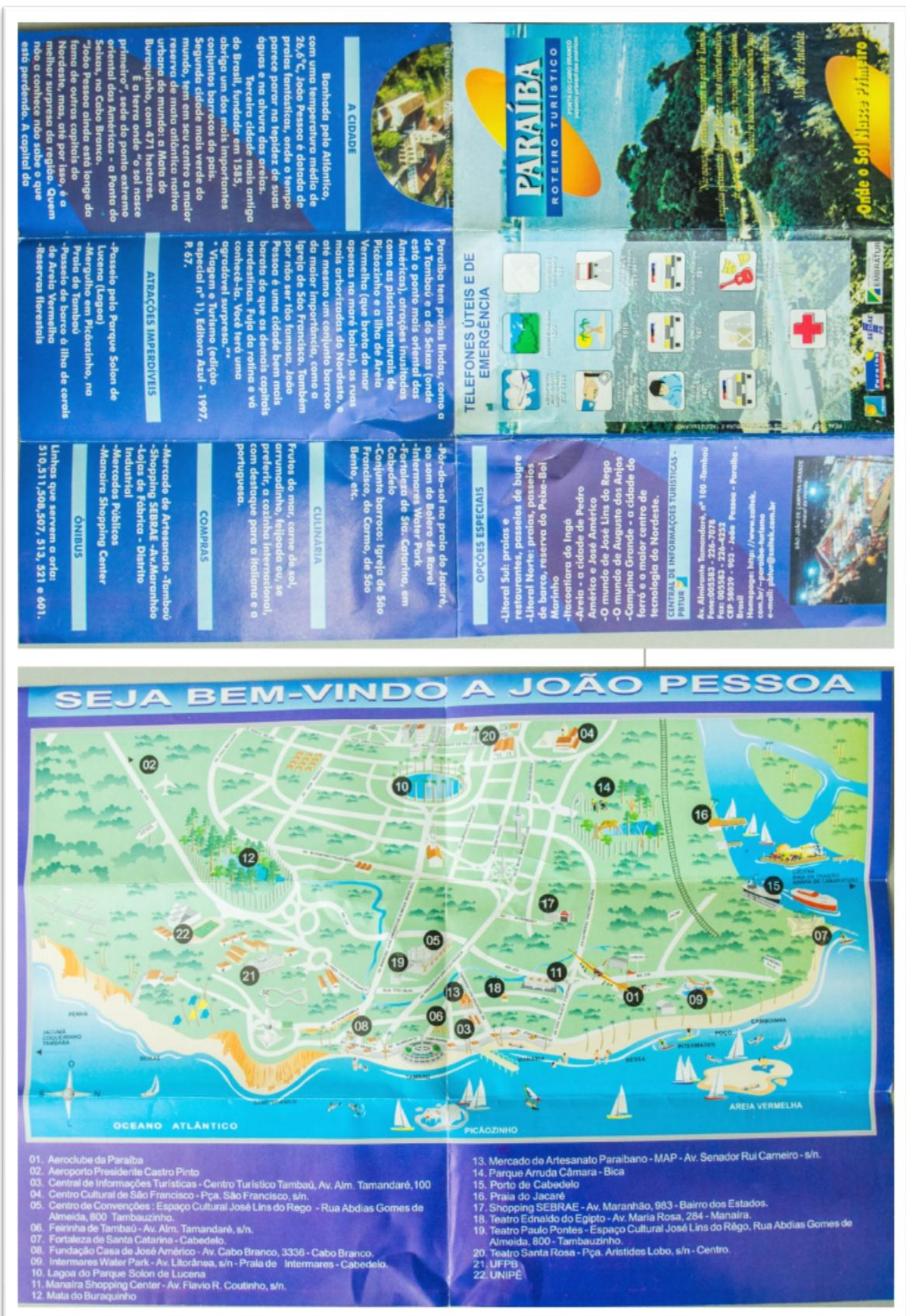

Mapa-Ficha 20 - Mapa turístico em formato de folder com título "Seja bem vindo à João Pessoa". Data aproximada: 1999 
Ficha 20 - Período/Ano de publicação: Data aproximada: 1999.

Breve descrição: Folder institucional dobrável, com dois lados, contendo mapa turístico da cidade. Possui um texto informativo sobre os aspectos turísticos da cidade usando as conhecidas frases de efeito e os slogans já muito conhecidos sobre a cidade. Contém Telefones úteis de emergência e informações rápidas sobre: culinária, ônibus, compras, atrações. Contém também duas pequenas fotos, uma da Igreja de São Francisco e outra do São João de Campina Grande. Destacamos que, parte do texto informativo sobre a cidade pertence a uma publicação cuja fonte é: Viagem e Turismo (edição especial $n^{\circ} 1$, Editora Azul, 1997).

Tipo de suporte (folder, encarte, para parede, etc): Folder

Título do folder: PARAÍBA - Roteiro Turístico.

Título da mapa: Seja bem vindo à João Pessoa

Ponto de vista do observador (ou usuário do mapa): Vista no sentido de Leste para

Oeste.

Foto da capa: Ponta do Cabo Branco (Na capa comete o erro de chamar a ponta do

Cabo Branco de ponto mais oriental).

Escala: Não consta.

Rosa dos ventos: Sim.

Os limites representados (as bordas do espaço representado):

Na borda inferior (leste) o limite é a faixa litorânea, da cidade de Cabedelo à praia da Penha. Na borda lateral esquerda (Sul), o limite do mapa é a área que corresponde à parte sul e sudoeste da cidade cujos bairros são Mangabeira, Geisel, Ernani Sátiro, e Distrito industrial. Destaco, no entanto que nesta área não consta nenhum topônimo. $\mathrm{Na}$ borda superior (oeste), o limite do mapa nem chegou a representar o Centro histórico nem o Bairro do Varadouro, onde se encontram os principais pontos turísticos. O limite ficou na Lagoa, na praça João Pessoa e na rua Visconde de Pelotas. Na borda lateral direita (Norte) os limites são o rio Paraíba e a cidade de Cabedelo.

Público alvo: Turistas em geral

Slogans e/ou frases de efeito: "...onde o sol nasce primeiro"

$$
\begin{aligned}
& \text { "Extremo oriental das Américas" } \\
& \text { "Terceira cidade mais antiga do Brasil" } \\
& \text { "Segunda cidade mais verde do mundo" } \\
& \text { "... tem em seu centro a maior reserva de mata atlântica } \\
& \text { nativa urbana do mundo..." }
\end{aligned}
$$

Topônimos citados: Pontos turísticos numerados e nomeados em legenda. Principais ruas e avenidas, Praias: Camboinha, Poço, Intermares, Bessa, Tambaú, Cabo Branco, Seixas e Penha. Areia Vermelha e Picãozinho. Placas indicativas: Transamazônica, Jacaré, Cabedelo, Praia do Sol. Setas indicativas: Lucena, Baía da Traíção, Barra de Camaratuba, Jacumã, Coqueirinho, Tambaba.

Instituição responsável por propor ou encomendar o mapa: Governo do Estado/PBTUR

Empresa responsável pela execução do projeto, impressão do mapa: Real 2000.

Fotos: Gustavo Moura e Tadeu Lubano.

Governador da época: José Targino Maranhão

Autor do mapa: Não identificado. 


\section{Ficha 21}

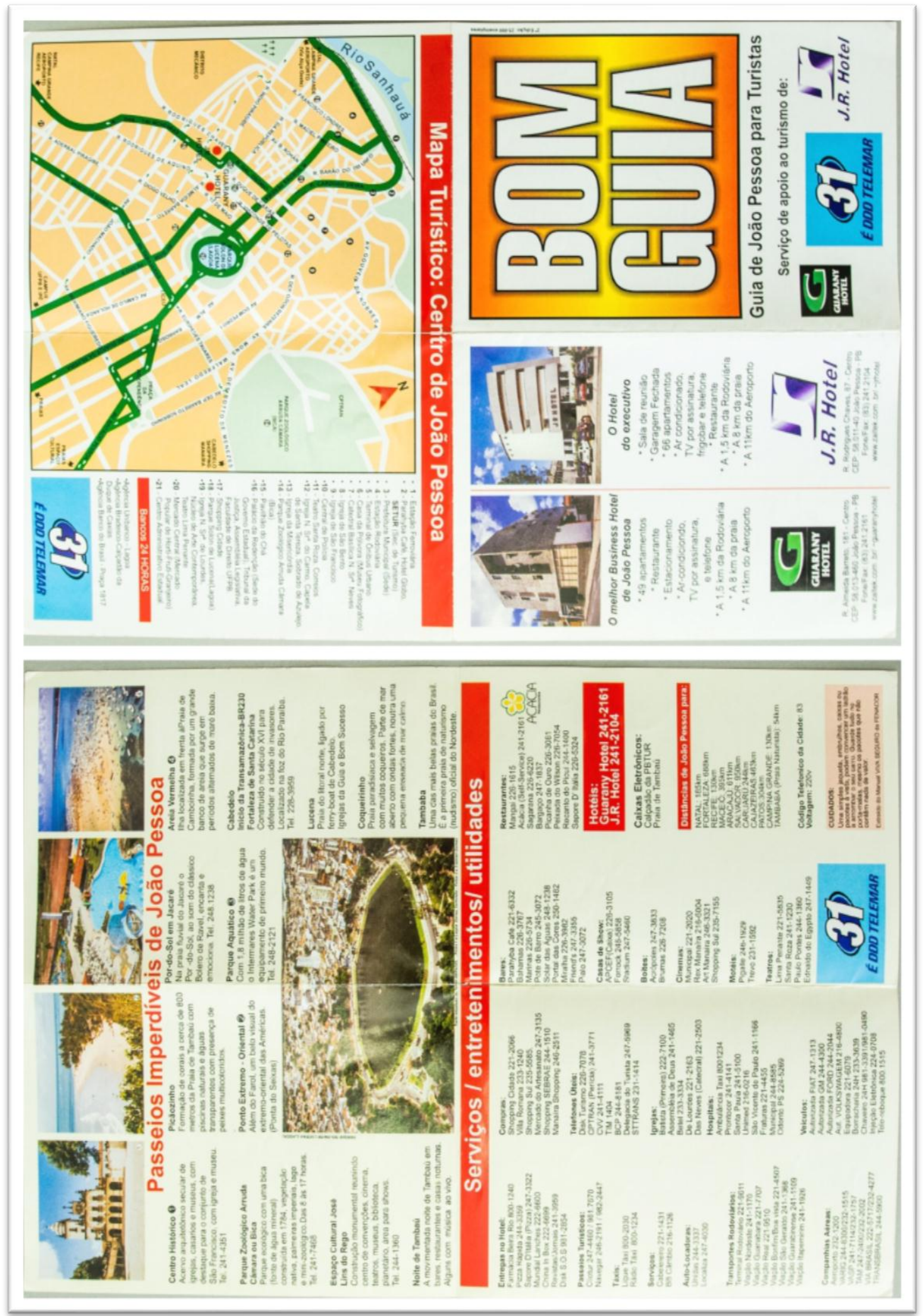

Mapa-Ficha 21 - Guia de João Pessoa para turistas. Data aproximada: 1999. 
Ficha 21 - Período/Ano de publicação: Provavelmente de 1999.

Observações: data presumida a partir da presença da publicidade das companhias aéreas Varig e Vasp que operaram no Brasil até o ano de 2005. Além desse indício, os números de telefones com 3 dígitos iniciais existiram até aproximadamente 2002. No entanto, há apresença de alguns números de telefones celulares. Existe também uma fotografia do Parque Aquático Intermares Water Park que encerrou suas atividades no ano de 2000.

Breve descrição: Folder com um mapa do Centro da cidade tendo como destaque a localização dos dois hotéis e a Lagoa. Contém fotos que destacam alguns pontos de "passeios imperdíveis de João Pessoa": Foto da Igreja de São Francisco - indicada como Centro Histórico. Foto da Praia do Seixas - indicada como ponto mais oriental. Tipo de suporte (folder, encarte, para parede, etc): Folder.

Título do Folder: BOM GUIA - Guia de João Pessoa para Turistas

Título do Mapa: Mapa Turístico Centro de João Pessoa

Ponto de vista do observador (ou usuário do mapa): Vista vertical característica de planta urbana.

Foto da capa Parque Aquático Waterpark - Foto de Areia Vermelha -

Escala: Não consta.

Rosa dos ventos: Consta a indicação do norte.

Os limites representados (as bordas do espaço representado):

No lado superior norte a limite é o Rio Sanhauá;

No lado posterior sul, a rua Maximiniano Figueiredo;

No lado direito leste do mapa o limite é o "Parque zoológico Arruda Câmara (Bica)";

No lado esquerdo oeste o limite é o Distrito mecânico e o Cemitério da Boa Sentença.

Público alvo: Turistas que se hospedam no centro da cidade.

Slogans e/ou frases de efeito: Não consta.

Principais pontos ou locais destacados: Os dois hotéis e a Lagoa do Parque Solon de Lucena.

Topônimos citados: Nomes das principais ruas do centro da cidade. Lagoa do Parque Solon de Lucena. Parque Zoológico Arruda Câmara (Bica), Praça da Independência, Distrito mecânico, Liceu.

Instituição responsável por propor ou encomendar o mapa: Material de publicidade dos hotéis Guarany e J.R. Hotel. Aparece um apoio da antiga companhia telefônica Telemar.

Empresa responsável pela execução do projeto, impressão do mapa: Não identificada.

Autor do mapa: Não identificado 


\section{Ficha 22}

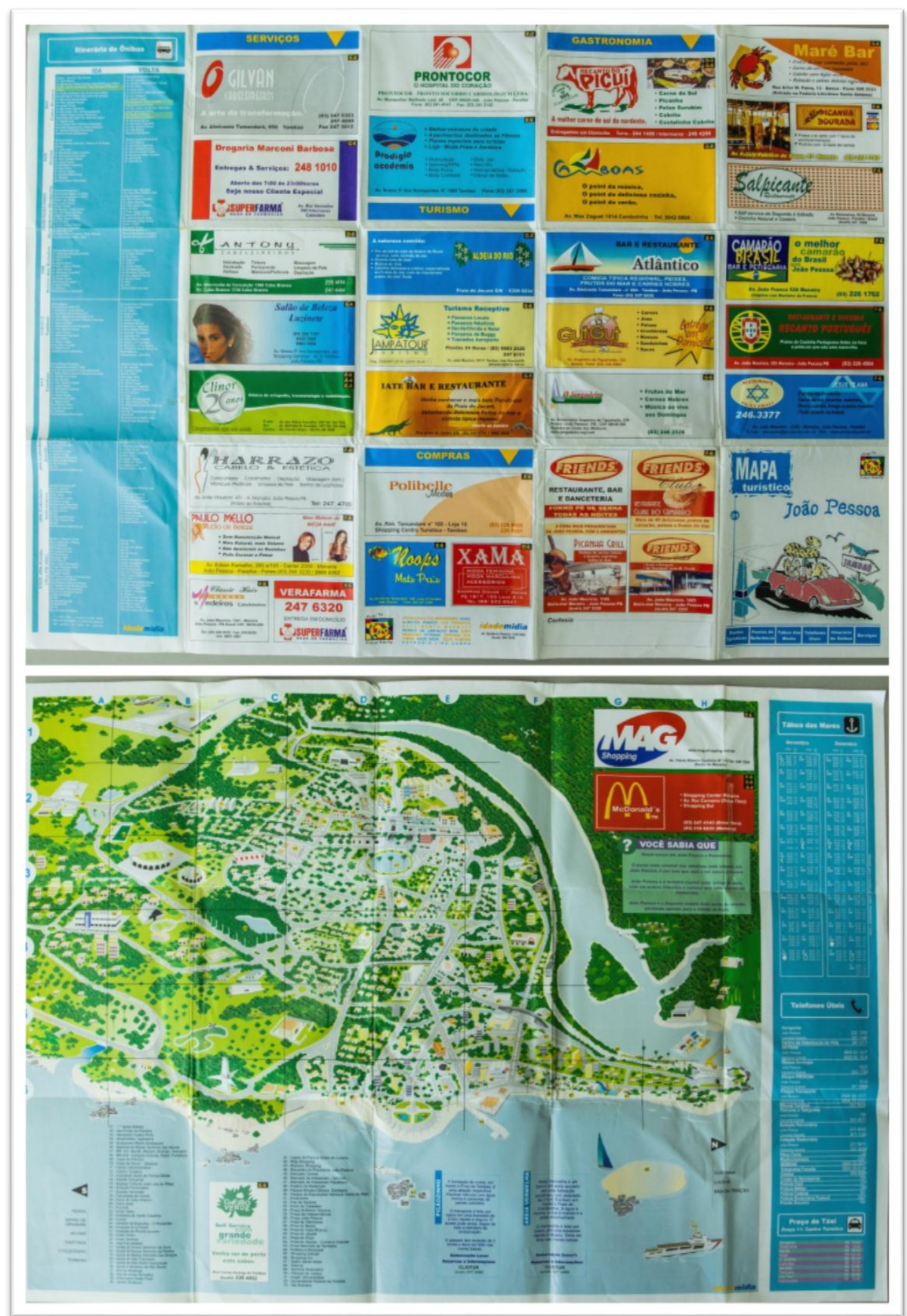

Mapa-Ficha 22 - Mapa turístico João Pessoa. Material em formato de folder publicitário com diversas informações turísticas. Data: 1999. 
Ficha 22 - Período/Ano de publicação: 1999.

Observações: data presumida a partir de alguns detalhes das informações: Intermares Water Park que encerrou as atividades em 2000. A presença de números de telefones com 3 dígitos iniciais. Não aparece o Shopping Tambiá que foi inaugurado em 2002.

Breve descrição: Folder mapa dobrável, com mapa turístico e grande teor publicitário. Apresenta a tábua das marés, telefones úteis e itinerário de ônibus.

Tipo de suporte (folder, encarte, para parede, etc): Folder

Título dofolder: Mapa Turístico - João Pessoa.

Título do mapa: Não consta título do mapa.

Ponto de vista do observador (ou usuário do mapa): Perspectiva de visão sentido de leste para oeste.

Foto da capa: Sem foto. A capa é um desenho de um carro vermelho com uma família de turistas.

Escala: Não consta escala.

Rosa dos ventos: apenas indicação do norte

Os limites representados (as bordas do espaço representado):

Na borda inferior (Leste): o litoral de Cabedelo até a Igreja da Penha na Praia de mesmo nome.

Na borda lateral esquerda (Sul): Bairro de Mangabeira e o Distrito Industrial;

Na borda superior (Oeste): Aeroporto Castro Pinto e o Rio Sanhauá.

Na borda lateral direita (Norte): Foz do rio Sanhauá e o município de Cabedelo.

Público Alvo: Turistas em geral.

Slogans e/ou frases de efeito: "O ponto mais oriental das Américas..."

"... aqui o sol nasce primeiro..."

“... Terceira capital mais antiga do país..."

“... segunda cidade mais verde do mundo, perdendo apenas para Paris"

Topônimos citados: Principais ruas, Areia Vermelha, Picãozinho, Penha, Barra de Gramame, Jacumã, Tabatinga, Coqueirinho, Tambaba.

Instituição responsável por propor ou encomendar o mapa: Consta publicidade de muitas empresas.

Empresa responsável pela execução do projeto, impressão do mapa: IDADE MIDIA - Produção e colaboradores: Isaac Almeida Ramos, Ilka Fernanda Nascimento Marques, Patrice de Carvalho Maia, Eliseu Rodrigues. Apoio: STTRANS e Capitania dos Portos. Idade Mídia: Zélia Almeida e Petrônio Lins Cunha.

Autor do mapa: Não identificado. 
Ficha 23
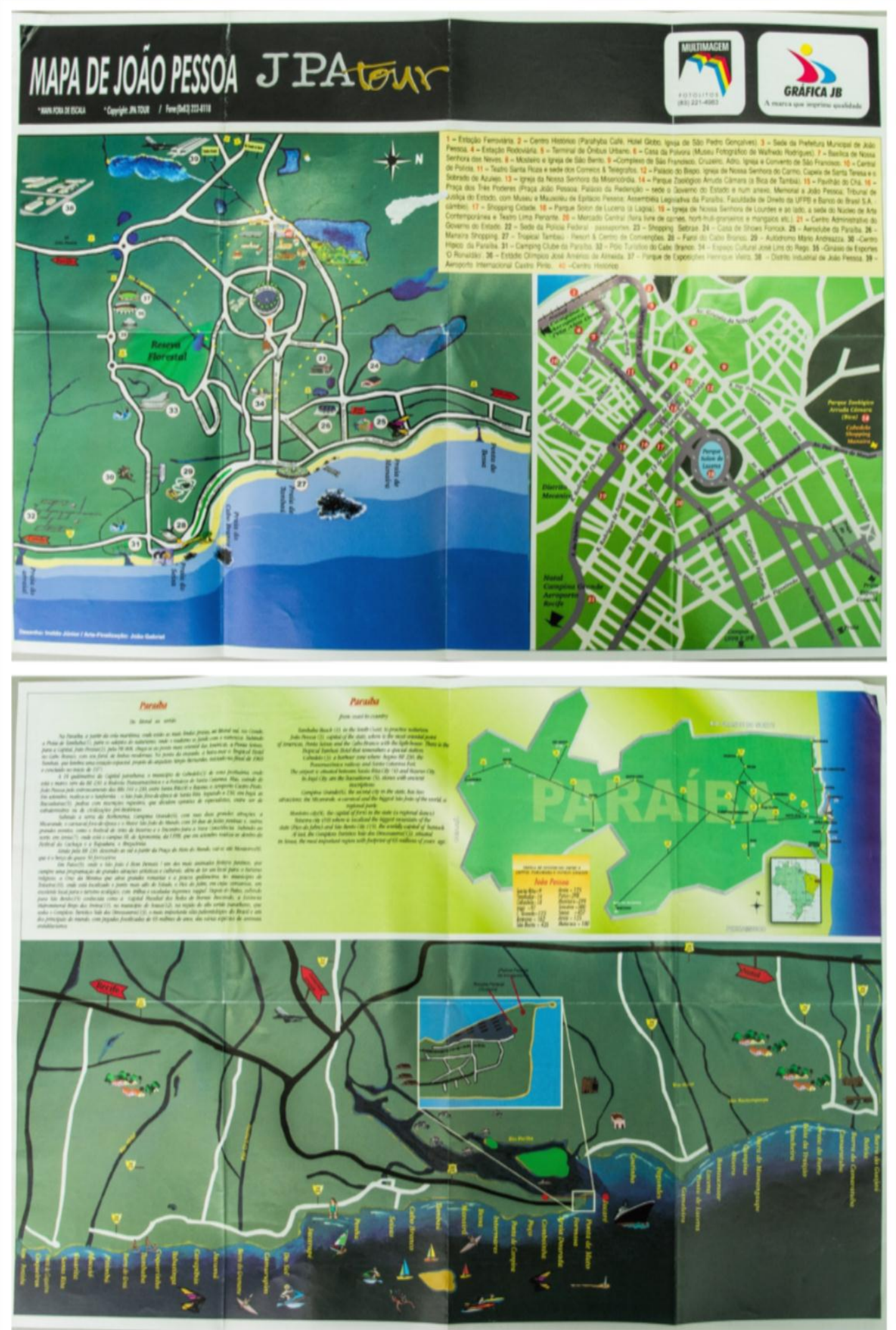

Mapa-Ficha 23 - Mapa de João Pessoa JPA Tour. Data: 1999. 
Ficha 23 - Período/Ano de publicação: 1999.

Observações: Não aparecem os shoppings MAG e o Tambiá Shopping. Aparecem números de telefones com formatos antigos, com 3 dígitos iniciais. A praia do Jacaré está localizada no lugar errado.

Breve descrição: Mapa frente e verso. O lado principal (que tem o título) apresenta dois mapas:

1 - O primeiro mapa é bem simplificado e tem apenas as principais vias da cidade e apresenta a cidade como um todo, ou seja, praia, bairros e centro (sem muitos detalhes), neste mapa consta a rosa dos ventos.

2 - O segundo mapa é semelhante aos mapas das listas telefônicas da Listel. Neste mapa constam as ruas com os respectivos topônimos. Não consta escala nem rosa dos ventos.

No lado oposto ao lado principal existem dois mapas:

1 - um mapa do litoral que apresenta todas as praias desde o litoral norte em Cabedelo até a praia de Maceió no município de Pitimbu no sul do litoral do estado. Este mapa do litoral do estado é um pouco confuso, não apresenta escala nem rosa dos ventos, a representação das estradas se confunde com a dos rios por causa da cor. Não tem escala nem rosa dos ventos.

2 - um outro mapa menor da Paraíba com a BR 230 e poucas outras estradas secundárias. Não tem escala. Apresenta uma rosa dos ventos.

Ainda neste lado do mapa existe um texto com o título "Paraíba, do litoral ao sertão" onde se faz a apresentação de várias cidades da Paraíba. Há também um pequeno texto simplificado em inglês com a apresentação do estado.

Tipo de suporte (folder, encarte, para parede, etc): Mapa avulso.

Título do mapa Mapa de João Pessoa JPA.Tour

Foto da capa: Não tem capa

Escala: Não consta.

Rosa dos ventos: nem todos os mapas apresentam.

Os limites representados (as bordas do espaço representado):

No lado principal do encarte:

O primeiro mapa:

A borda inferior do lado Leste tem o oceano como limite e representa o litoral da cidade, desde a praia do Bessa até a praia do Arraial no município de Pitimbu.

Na borda esquerda sul tem o município do Conde e o Distrito Industrial de João Pessoa;

Na borda superior-Oeste o limite é o aeroporto;

Na borda direita-Norte o limite é o Centro Histórico e toda área alagada do Rio

Sanhauá,

O segundo mapa:

Na borda inferior-Sul o limite são as avenidas Duarte da Silveira, Maximiniano Figueiredo e João Machado.

Na borda esquerda-Oeste no limite está o Distrito dos Mecânicos;

Na borda superior norte o limite é o Bairro do Varadouro (Rua Maciel Pinheiro)

A borda direita-Leste tem como limite o Parque Arruda Câmara (Bica) e a Praça da Independência. 
No lado oposto: O mapa do litoral do Estado:

Na borda inferior tem o oceano e todas as praias desde a Barra do Guajaú no litoral norte até a praia de Maceió no município de Pitimbu.

A borda esquerda-sul tem o limite da Paraíba com Pernambuco

Na borda superior oeste: a BR 101.

Na borda direita-Sul tem o limite da Paraíba com o Rio Grande do Norte.

Público alvo: Turistas nacionais e estrangeiros

Slogans e/ou frases de efeito: “... ponto mais oriental das Américas"

“... onde está o marco zero da BR 230, a rodovia Transamazônica..."

Instituição responsável por propor ou encomendar o mapa: Gráfica JB e Multimagens Empresa responsável pela execução do projeto, impressão do mapa: Gráfica JB. Desenho: Inaldo Júnior. Arte finalização: João Gabriel.

Autor do mapa: Inaldo Júnior. 


\section{Ficha 24}

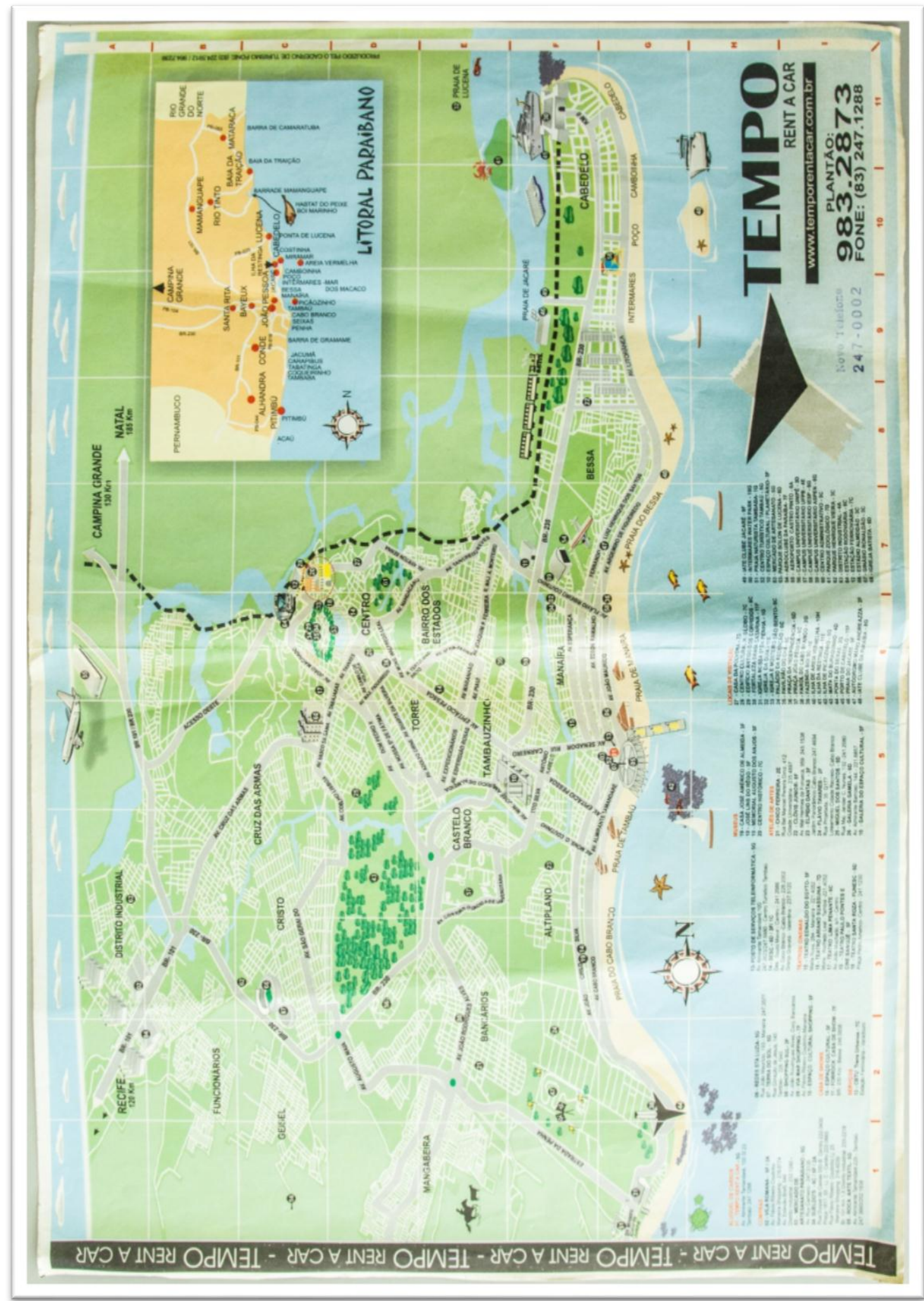

Mapa-Ficha 24 - Mapa de João Pessoa pertencente ao Caderno de Turismo. Data: 2000. 
Ficha 24 - Período/Ano de publicação: 2000.

Observações: poucos elementos indicam a data, como os números de telefone. Consta o Intermares Water Park que encerrou as atividades em 2000.

Breve descrição: Mapa impresso apenas de um lado. A parte superior direita do mapa contém outro mapa em tamanho menor do litoral da Paraíba.

Tipo de suporte (folder, encarte, para parede, etc): Encarte do Caderno de Turismo.

Título do mapa: o mapa principal não apresenta um título.

Ponto de vista do observador (ou usuário do mapa): perspectiva de visão de leste para oeste.

Foto da capa: Não consta.

Escala: Não consta

Rosa dos ventos: Sim.

Os limites representados (as bordas do espaço representado):

$\mathrm{Na}$ borda do lado leste está o litoral iniciando do lado direito pela ponta de Cabedelo indo até a praia da Penha.

Contornando a borda pelo lado Sul o limite representado pelo mapa é o bairro de Mangabeira.

Na borda oeste está o Distrito Industrial e na extremidade oeste o limite do mapa é o Centro Histórico da cidade.

Público Alvo: Turistas em geral.

Slogans e/ou frases de efeito: Não constam.

Topônimos citados: Alguns bairros da cidade, Praias: Cabedelo, Camboinha, Poço, Intermares, Bessa, Manaíra, Tambaú e Cabo Branco. Além das praias de Lucena e Jacaré.

Instituição responsável por propor ou encomendar o mapa: TEMPO Rent a car Locadora.

Empresa responsável pela execução do projeto, impressão do mapa: Caderno de Turismo.

Autor do mapa: Não identificado 


\section{Ficha 25}
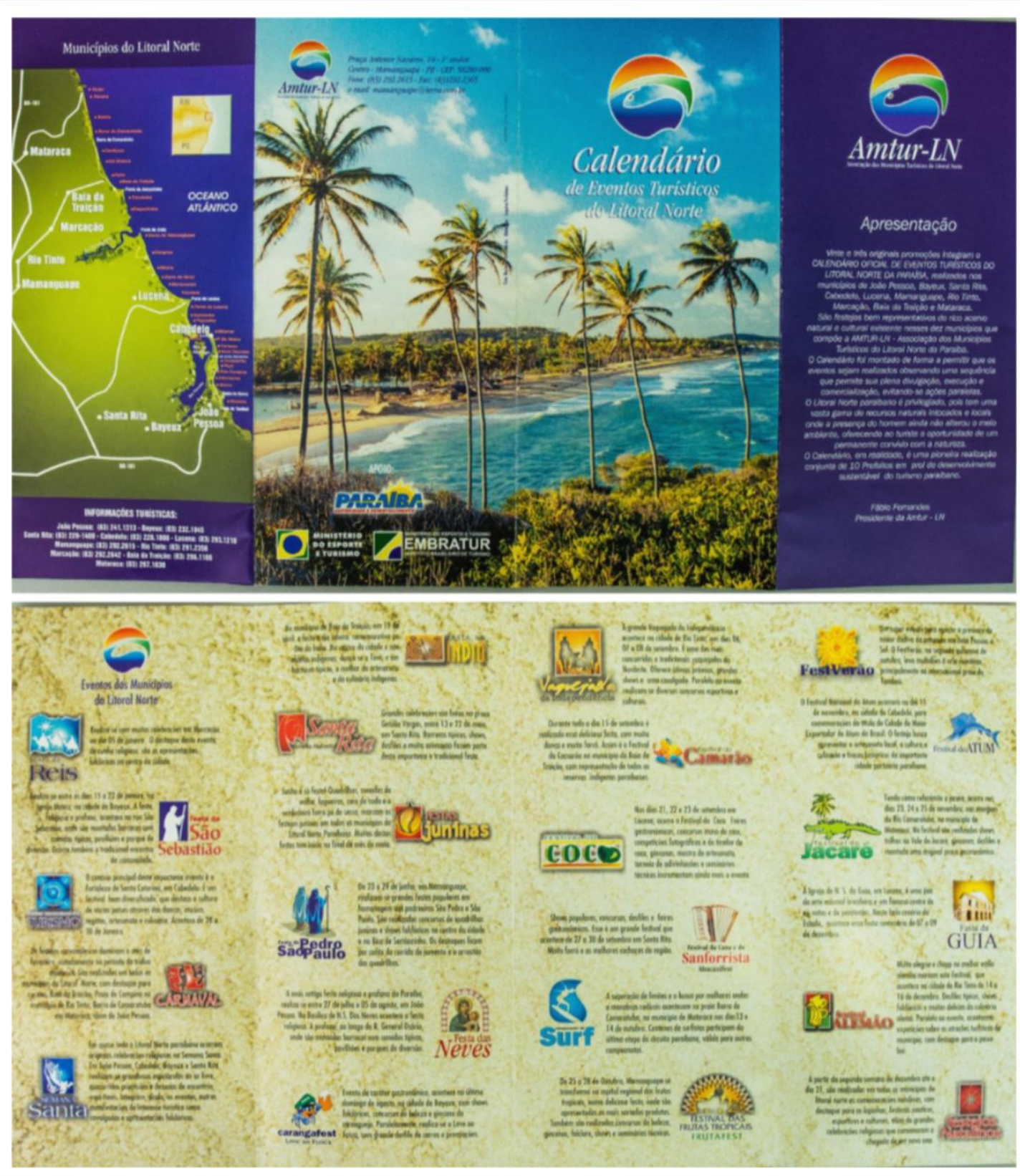

Mapa-Ficha 25 - Calendário de eventos turísticos dos municípios do litoral norte do Estado da Paraíba. A figura ilustra frente e verso do folder. Data aproximada: 2000. 
Ficha 25 - Período/Ano de publicação: Aproximadamente 2000

Breve descrição: Folder de divulgação de calendário de eventos turísticos dos municípios do litoral norte do Estado da Paraíba. Material dobrável, de um lado apresenta uma fotografia da Barra de Camaratuba e um mapa do litoral norte do estado. Do lado oposto uma descrição de cada evento a acontecer nesses municípios, organizados em ordem dos meses do ano.

Suporte (folder, encarte, para parede, etc): Folder

Título do Folder: Calendário de Eventos Turísticos do Litoral Norte.

Título do mapa: Municípios do Litoral Norte.

Foto da capa: Barra de Camaratuba.

Escala: Não consta.

Rosa dos ventos: Não consta.

Os limites representados (as bordas do espaço representado): O mapa é exclusivo do litoral norte do estado, então a representação inicia em Mataraca, que é o município do extremo norte e segue até o município de João Pessoa.

Público alvo: Turistas em geral.

Slogans e/ou frases de efeito: Não identificado

Topônimos citados: Apenas os nomes dos municípios e os nomes das praias.

Instituição responsável por propor ou encomendar o mapa: Amtur (Associação dos municípios turísticos do litoral norte), com apoio do Governo do estado, Ministério do Esporte e Turismo e Embratur,

Empresa responsável pela execução do projeto, impressão do mapa: Não identificada.

Autor do mapa: Não identificado. 


\section{Ficha 26}

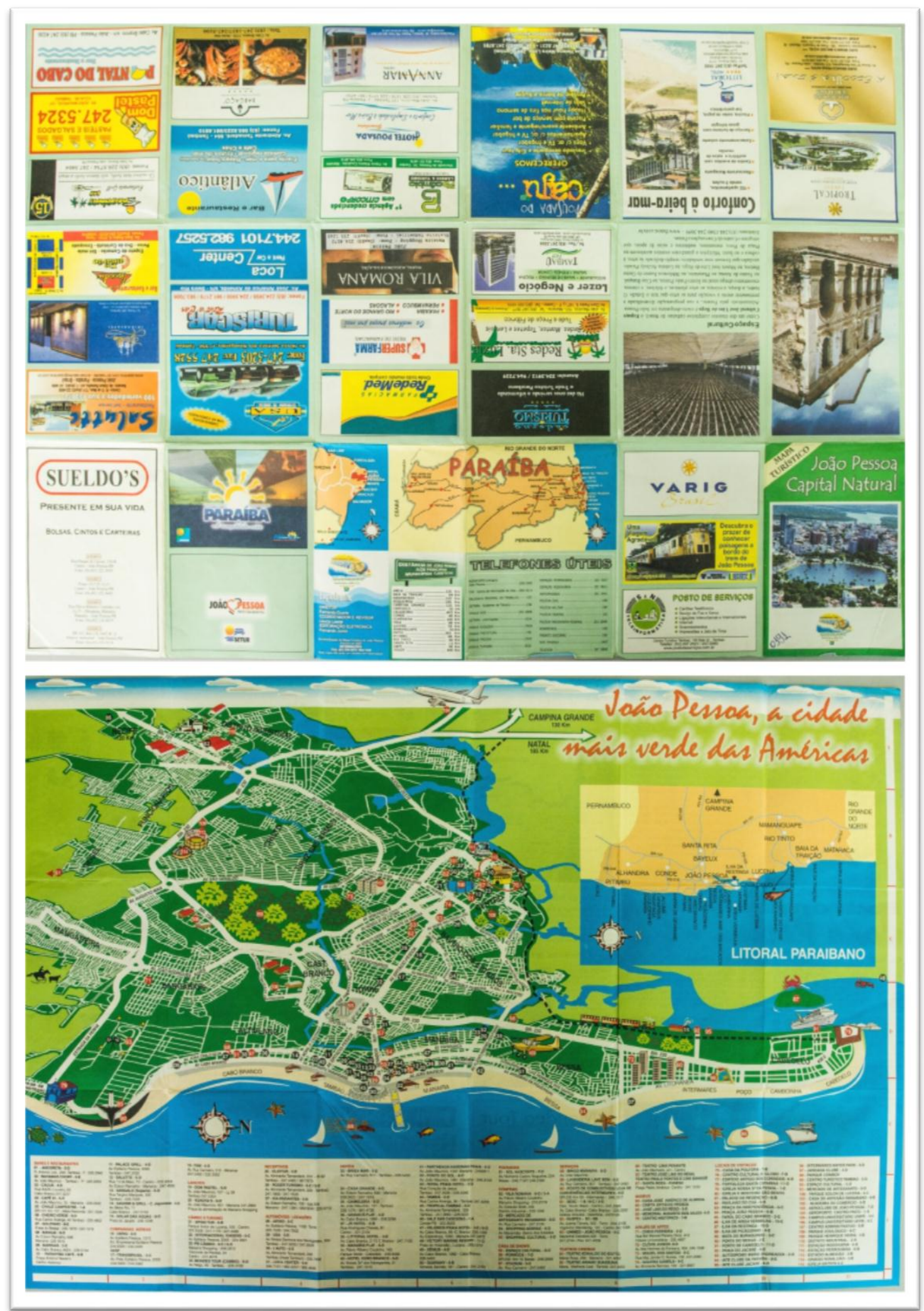

Mapa-Ficha 26 - Mapa turístico “João Pessoa Capital Natural”. Material impresso em frente e verso, em formato de folder dobrável com propagandas e mapa turístico da cidade. Data: 2000. 
Ficha 26 - Périodo/Ano de publicação: 2000.

Observações: Terceira edição do Mapa do Caderno de Turismo de João Pessoa. (Expediente: Diretor: Fernando Duarte; Coordenador e revisor: Léucio Laerte; Editoração eletrônica: Fernando Júnior.

Breve descrição: Mapa tipo folder institucional com forte teor publicitário. A parte superior direita do mapa contém um mapa em tamanho menor do litoral da Paraíba. No lado posterior do mapa-folder encontram-se diversas publicidades de empresas do meio turístico, tais como locadoras, hotéis, restaurantes, bares, entre outras. Contém também dois pequenos mapas, um do Estado da Paraíba e outro da Região Nordeste, listas com telefones úteis e listas com distâncias dos principais municípios turísticos.

Tipo de suporte: (folder, encarte, para parede, etc): Folder.

Título do Folder: Mapa Turístico - JOÃO PESSOA CAPITAL NATURAL

Título do Mapa: João Pessoa a cidade mais verde das Américas.

Ponto de vista do observador (ou usuário do mapa): Perspectiva de visão de leste para oeste.

Foto da capa: Foto da Lagoa do Parque Solon de Lucena com visão de leste para oeste, com vistas ao longe do rio Sanhauá.

Escala: Não consta.

Rosa dos ventos: Sim.

Os limites representados (as bordas do espaço representado): Na borda do lado leste está o litoral iniciando do lado direito pela ponta de Cabedelo indo até a praia da Penha. Contornando a borda pelo lado Sul o limite representado pelo mapa é o bairro de Mangabeira. Na borda oeste está o Distrito Industrial e na extremidade oeste o limite do mapa é o Centro Histórico da cidade.

Público Alvo: Turistas de um modo geral.

Slogans e/ou frases de efeito: A frase do título do mapa: "João Pessoa capital natural" e "João Pessoa a cidade mais verde das Américas".

Topônimos citados: Nomes das principais avenidas, Bairros e praias.

Instituição responsável por propor ou encomendar o mapa: Prefeitura Municipal / SETUR.

Empresa responsável pela execução do projeto, impressão do mapa: Caderno de Turismo.

Prefeito da época: Cícero Lucena.

Autor do mapa: Não identificado 
Ficha 27

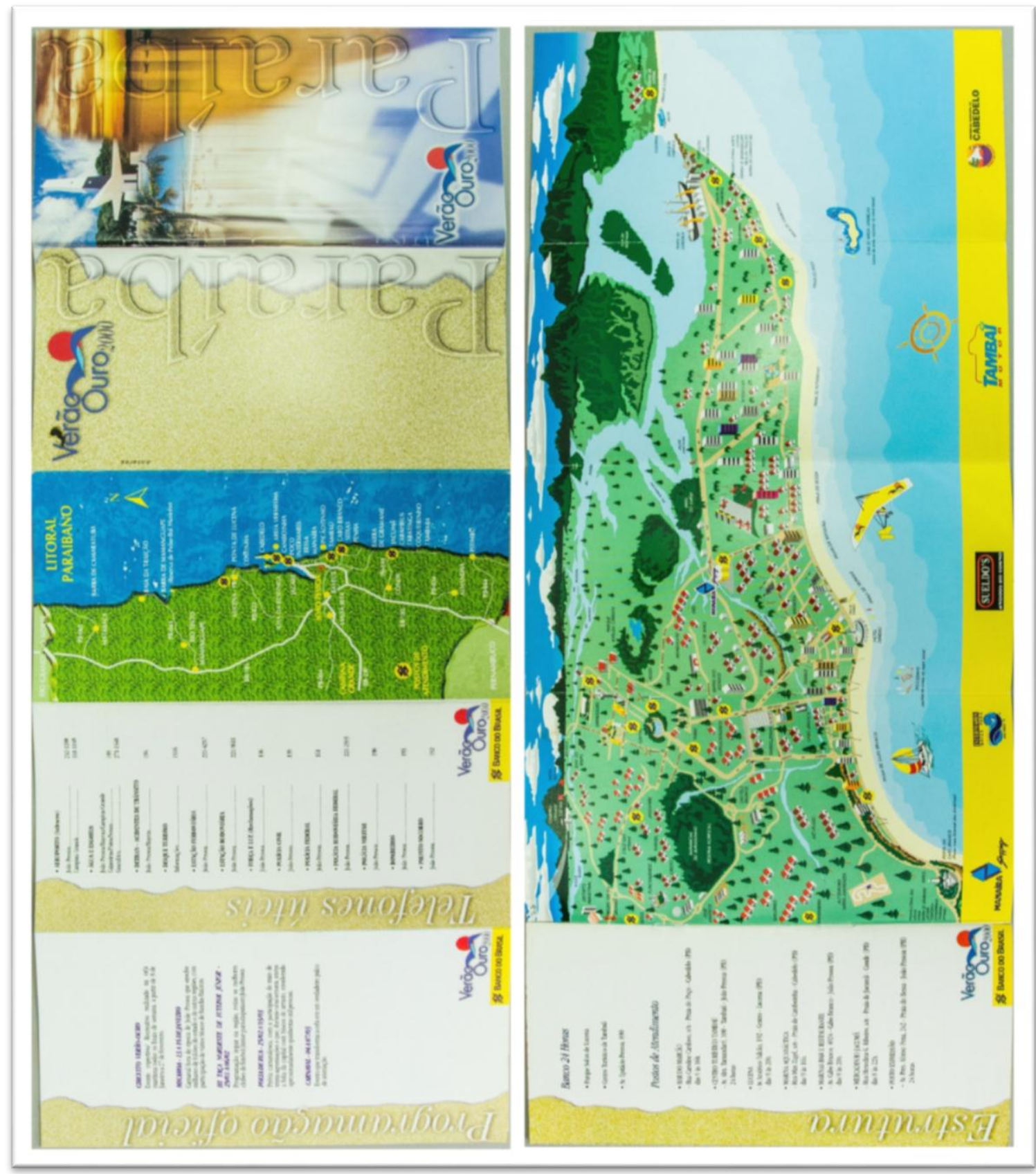

Mapa-Ficha 27 - Mapa “Paraíba - Verão Ouro". Material publicitário do Banco do Brasil. Data: 2000. 
Ficha 27 - Período/Ano de publicação: 2000.

Observações: Aparece os topônimos Bayeux e Mata do Amém que praticamente não aparecem em outros mapas analisados,

Aparece a Ponta do Cabo Branco equivocadamente como o ponto mais oriental das Américas.

Não aprece nenhuma igreja mapeada, nem aquelas que são pontos turísticos.

Breve descrição: Folder publicitário dobrável. Material publicitário do Banco do Brasil, com anúncio também do Manaíra Shopping, Intermares Water Park, Sueldo's, Tambaí Motor, Prefeitura de Cabedelo. Apresenta a localização de todas as agências do Banco do Brasil e do Manaíra Shopping.

Tipo de suporte (folder, encarte, para parede, etc): Folder

Título do folder: PARAIIBA - Verão Ouro

Título do mapa: não consta.

Ponto de vista do observador (ou usuário do mapa): perspectiva de visão no sentido de leste para oeste.

Foto da capa: Montagem com o Farol do Cabo Branco e a beira mar.

Escala: Não consta

Rosa dos ventos: Sim.

Os limites representados (as bordas do espaço representado):

$\mathrm{Na}$ borda inferior (Leste): a faixa do litoral com as praias, desde Lucena até a Ponta do Cabo Branco. Na borda lateral esquerda (Sul): uma linha que vai da Ponta do Cabo Branco, passando pelos Bairros de Mangabeira, Bancários, José Américo, Ernesto Geisel e o Distrito Industrial. Na borda superior (Oeste): estão o Açude Marés, a Ilha do Bispo, o Município de Bayeux, os rios Sanhauá e o Paraíba. Na borda do lado direito do mapa está o Município de Lucena.

Público alvo: Turistas, preferencialmente clientes do Banco do Brasil.

Slogans e/ou frases de efeito: o ponto mais oriental das Américas

Principais pontos ou locais destacados: Agências do Banco do Brasil e o Farol do

Cabo Branco Cor predominante: Verde

Topônimos citados: A maioria dos Bairros e as principais avenidas, os Rios Sanhauá, Paroeiras, Paraíba, Mandacarú, Jaguaribe, e o Açude Marés. Pela primeira vez percebi a Mata do Amém ser citada. O manancial do Buraquinho, Parque Arruda Câmara, Ilha da Restinga, Porto de Cabedelo, Dique de Cabedelo, Costinha, Cidade de Lucena, Praia de Lucena, Ilha de Areia Vermelha, Picãozinho, Ponta do Cabo Branco, Autódromo Mário Andreaza, Pier de Tambaú, praia do Jacaré, Bayeux. São citadas também as principais praias do litoral, incluindo as principais do litoral norte e do litoral sul.

Instituição responsável por propor ou encomendar o mapa: Banco do Brasil. Empresa responsável pela execução do projeto, impressão do mapa: Antares. Autor do mapa: Não identificado. 


\section{Ficha 28}

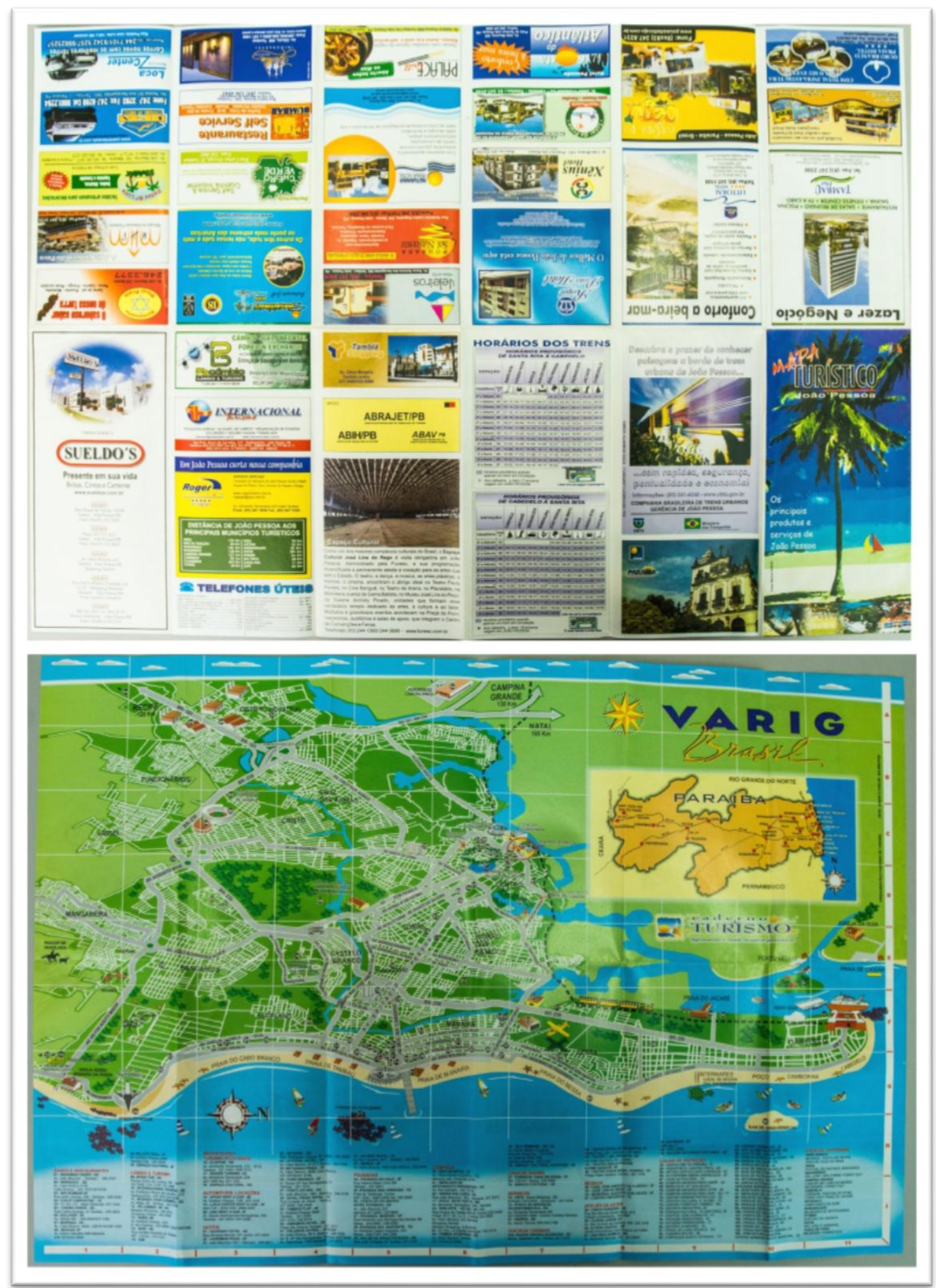

Mapa-Ficha 28 - Mapa Turístico João Pessoa - os principais produtos e serviços de João Pessoa. Data: Aproximadamente 2000. 
Ficha 28 - Período/ano de publicação: 2000.

Observações: data presumida pela presença no mapa do Intermares Water Park (que encerrou atividades em 2000) e do Jardim Botânico Benjamim Maranhão criado neste ano.

Breve descrição: Folder institucional com a logomarca do Governo do Estado. Dobrável, com um mapa da cidade de João Pessoa de um lado e, do outro, muitas publicidades de empresas ligadas ao turismo.

Tipo de suporte (folder, encarte, para parede, etc): Folder

Título dofolder: Mapa Turístico João Pessoa - os principais produtos e serviços de João Pessoa.

Título do mapa: Não consta.

Ponto de vista do observador (ou usuário do mapa): Perspectiva de visão no sentido de leste para oeste.

Foto da capa: Uma gravura feita em aquarela de um coqueiro em frente ao mar.

Escala: Não consta.

Rosa dos ventos: Sim.

Os limites representados (as bordas do espaço representado): $\mathrm{Na}$ borda direita (norte) do mapa está o município de Cabedelo e a praia de Lucena e a Igreja da Guia. Na borda inferior (leste) está a faixa litorânea com as praias, desde Cabedelo, ao norte, até a Ponta do Seixas ao sul. Na borda esquerda (norte) estão os bairros de Mangabeira, Geisel e Funcionários. Na borda superior (oeste) estão o Bairro do Distrito Industrial, o Aeroporto Castro Pinto, a BR 230 e a BR 101.

Público Alvo: Turistas em geral.

Slogans e/ou frases de efeito: Não consta

Topônimos citados: Apenas as principais avenidas. Bairros: Bessa, Manaíra, Altiplano, Mangabeira, Bancários, Tambauzinho, Castelo Branco, Bairro dos Estados, Torre, Centro, Geisel, Cristo, Cruz das Armas, Funcionários, Distrito Industrial. Reserva Florestal Jardim Botânico Benjamim Maranhão, Parque Arruda Câmara, Parque Solon de Lucena, Aeroporto Castro Pinto, Viaduto do Oitizeiro, UNIPÊ, PB 008 Ministro Abelardo Jurema, Igreja Nossa Senhora da Penha, Farol do Cabo Branco, Igreja da Guia, Forte Velho, Praias: Jacaré, Lucena, Camboinha, Poço, Intermares, Bessa, Manaíra, Tambaú e Cabo Branco. Corais de Picãozinho e Ilha de Areia Vermelha. Aparece o topônimo da praia de Tambaba, mesmo não constando no mapa.

Instituição responsável por propor ou encomendar o mapa: Governo do Estado / PBTUR, ABRAJET/PB (Associação Brasileira de Jornalista de Turismo), ABIH/PB (Associação Brasileira de Hotéis), ABAV/PB (Associação Brasileira de Agências de Viagens).

Empresa responsável pela execução do projeto, impressão do mapa: Caderno de turismo.

Governador da época: José Maranhão.

Autor do mapa: Arte: Júnior e Carlos 


\section{Ficha 29}

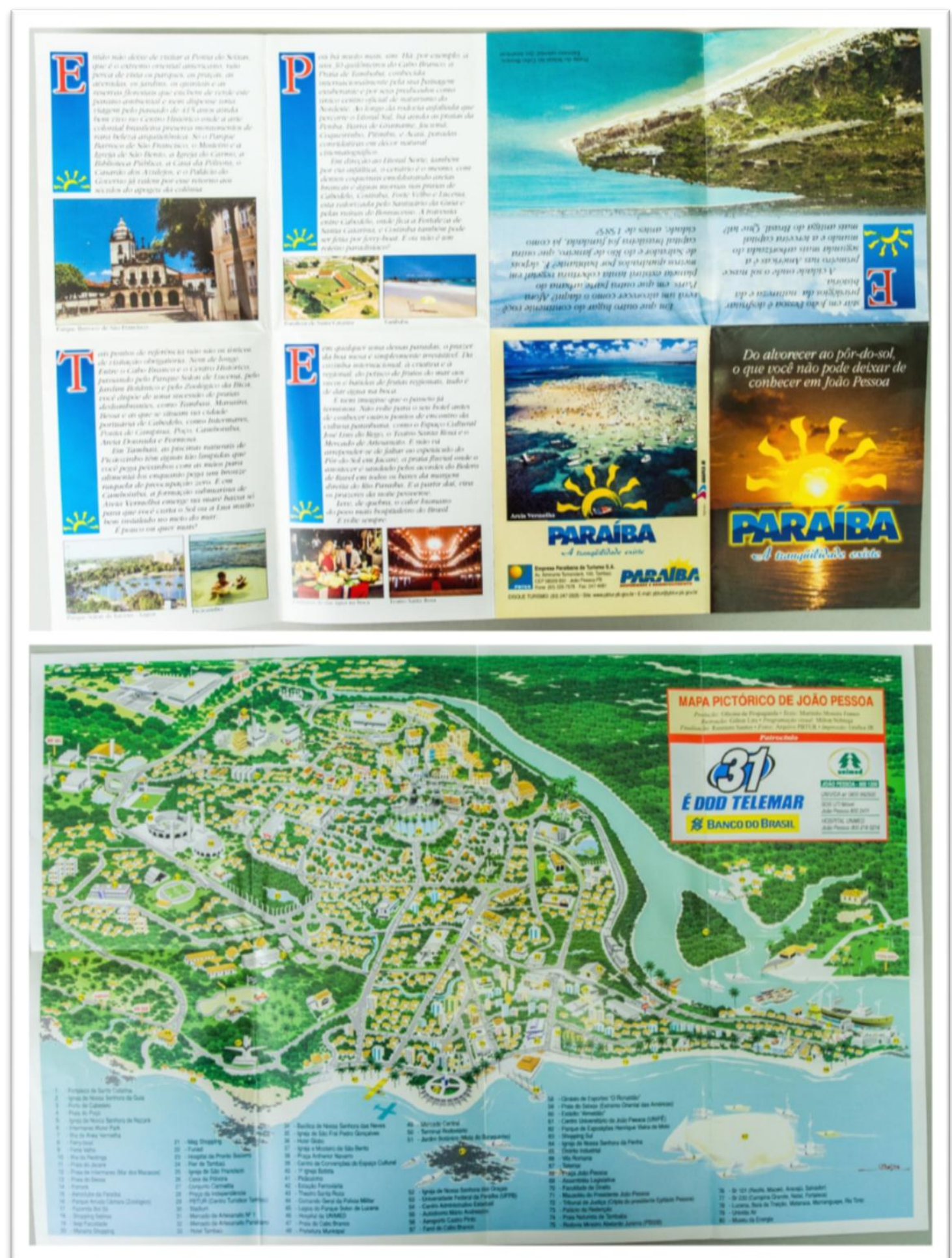

Mapa-Ficha 29 - Mapa Pictórico de João Pessoa. Folder institucional dobrável com um mapa da cidade. Data: 2000. 
Ficha 29 - Período/ano de publicação: 2000.

Observações: No texto consta a referência que a cidade tinha 415 anos. Apresenta logomarca do governo do estado: o nome PARAIIBA, com um sol e o slogan "Austeridade é desenvolvimento". Lugares em destaque: Fotografia em destaque da Ilha de Areia Vermelha, Fotos menores da Igreja de São Francisco, Teatro Santa Roza, Praia de Tambaba, Lagoa, Fortaleza de Sta Catarina, Picãozinho.

Breve descrição: Folder institucional dobrável com um mapa da cidade. Apresenta textos sobre as principais atrações turísticas da cidade e de municípios vizinhos.

Tipo de suporte (folder, encarte, para parede, etc): Folder

Título do folder: PARAÍBA - A tranquilidade existe.

Título do mapa: Mapa Pictórico de João Pessoa.

Ponto de vista do observador ( ou usuário do mapa): Perspectiva de visão no sentido de leste para oeste.

Foto da capa: Foto de um pôr do sol.

Escala: Não consta

Rosa dos ventos: Sim.

Os limites representados (as bordas do espaço representado): Na borda inferior (Leste): a faixa da costa com as praias que vai do litoral de Cabedelo até a Barra de Gramame. Na borda lateral esquerda (Sul): Bairro de Mangabeira e o Distrito Industrial; Na borda superior (Oeste): Aeroporto Castro Pinto e o Rio Sanhauá. Na borda lateral direita (Norte): Foz do rio Sanhauá e o município de Cabedelo.

Público Alvo: Turistas em geral.

Slogans e/ou frases de efeito: "Cidade onde o sol nasce primeiro nas Américas..."

"... segunda mais arborizada do mundo"

"... terceira capital mais antiga do Brasil"

"Extremo oriental das Américas"

Topônimos citados: Praticamente sem topônimos citados, apenas nomes das principais ruas e avenidas. Todos os lugares são numerados e indexados em uma legenda.

Instituição responsável por propor ou encomendar o mapa: Governo do Estado / PBTUR

Empresa responsável pela execução do projeto, impressão do mapa: Produção: Oficina de Propaganda. Texto: Martinho Moreira Franco. Ilustração: Gilton Lira. Programação visual: Milton Nóbrega. Finalização: Ranniere Santos. Fotos: Arquivo PBTUR. Impressão: Gráfica JB. Apoio e patrocínio: Unimed-JP, Telemar e Banco do Brasil.

Governador da época: José Maranhão

Autor do mapa: Gilton Lira 


\section{Ficha 30}

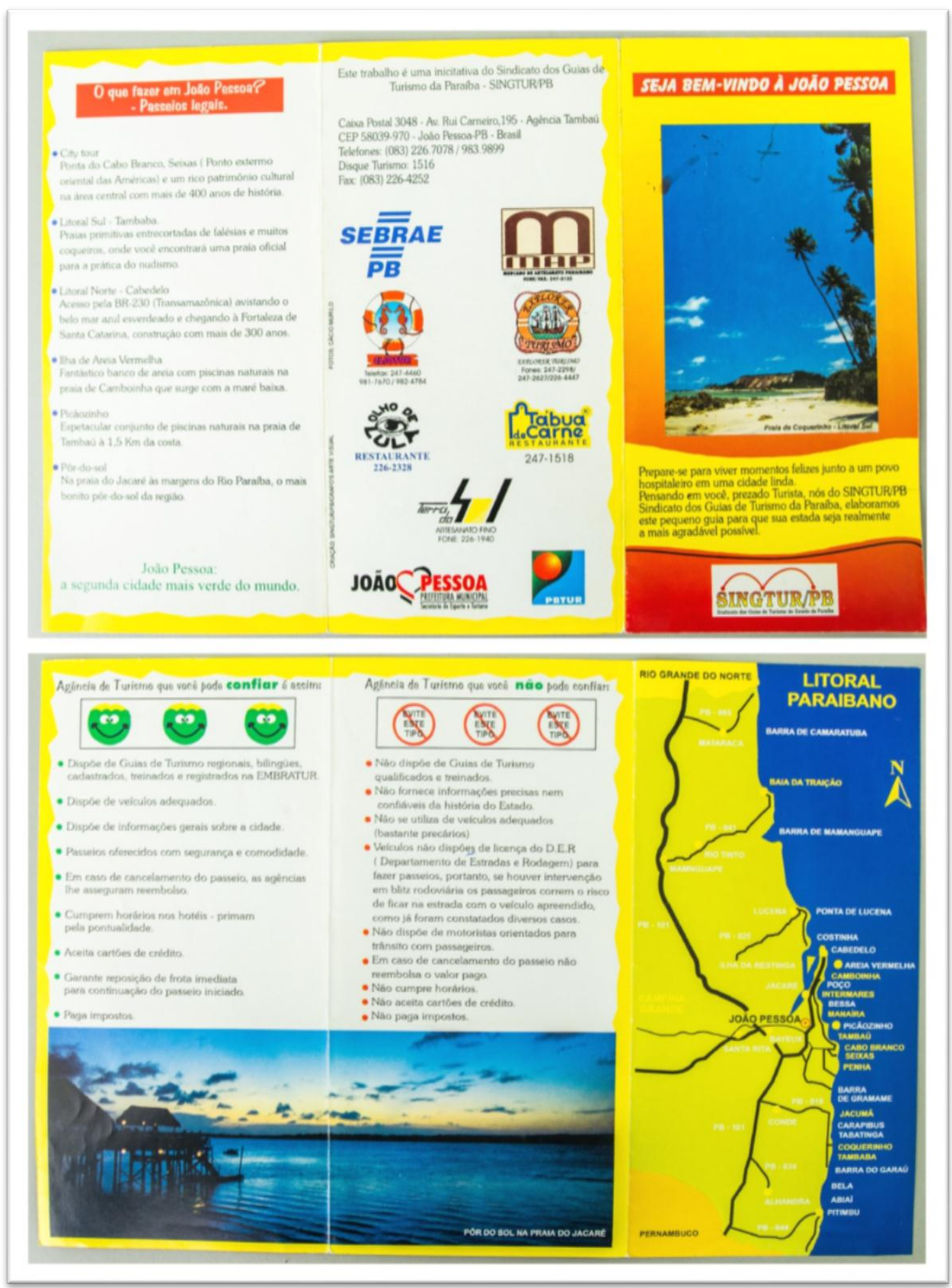

Mapa-Ficha 30 - Mapa turístico “Seja bem vindo à João Pessoa". Folder elaborado pela Prefeitura Municipal de João Pessoa. Data: 2001. 
Ficha 30 - Período/ano de publicação: 2001.

Observações: Data presumida a apartir de informações como a presença de uma logomarca da Prefeitura Municipal de João Pessoa com um coração que era a marca a gestão do prefeito Cícero Lucena.

Mesmo apresentando o Título "Seja bem vindo à João Pessoa" e destacando passeios e lugares turísticos na cidade, o folder apresenta apenas o mapa do litoral, que não orienta em nada os turistas na localização de todas as sugestões de passeios dadas.

Breve descrição: Folder dobrável elaborado pelo Sindicato dos Guias de Turismo da Paraíba - SINGTUR/PB. De um lado consta um mapa do litoral da Paraíba e listas indicando as características de agências de turismo "confiáveis". Do outro lado do folder estão: uma "lista do que fazer em João Pessoa" e logomarcas publicitárias de algumas empresas, bem como a logomarca da Prefeitura Municipal de João Pessoa e da PBTUR.

Tipo de suporte (folder, encarte, para parede, etc): Folder.

Título do folder: Seja bem vindo à João Pessoa.

Título do mapa: Litoral Paraibano.

Foto da capa: Foto da Praia de Coqueirinho. Outras fotografias: o Pôr do Sol na praia do Jacaré e a Praia de Coqueirinho.

Escala: Não consta.

Rosa dos ventos: Sim.

Os limites representados (as bordas do espaço representado): Apenas o litoral do Estado da Paraíba, desde o município de Mataraca na divisa com o RN, até o município de Pitimbu na divisa com PE.

Público alvo: Turistas em geral

Slogans e/ou frases de efeito: "João Pessoa: a segunda cidade mais verde do mundo"

Topônimos citados:

Praias: Barra de Camaratuba, Baía da Traição, Barra de Mamanguape, Ponta de Lucena, Costinha, Cabedelo, Areia Vermelha, Camboinha, Poço, Intermares, Bessa, Manaíra, Tambaú, Cabo Branco, Seixas, Penha, Barra de Gramame, Jacumã, Carapibus, Tabatinga, Coqueirinho, Tambaba, Barra do Garaú, Praia Bela, Abiaí, Pitimbu, Praia do Jacaré.

Pontos Turísticos: Picãozinho, Ilha da Restinga.

Cidades: Campina Grande, Mataraca, Rio Tinto, Mamanguape, Lucena, João Pessoa, Bayeux, Santa Rita, Conde, Alhandra.

Outros: PB 101 (nomeada erroneamente, pois esta estrada é BR 101), PB 065, PB 041, PB 025, PB 018, PB 034, PB 044.

Instituição responsável por propor ou encomendar o mapa: SINGTUR/PB.

Empresa responsável pela execução do projeto, impressão do mapa: Criação:

SINGTUR/PB e Grafo's Arte Visual. Fotografia: Cácio Murilo

Autor do mapa: Não identificado. 


\section{Ficha 31}

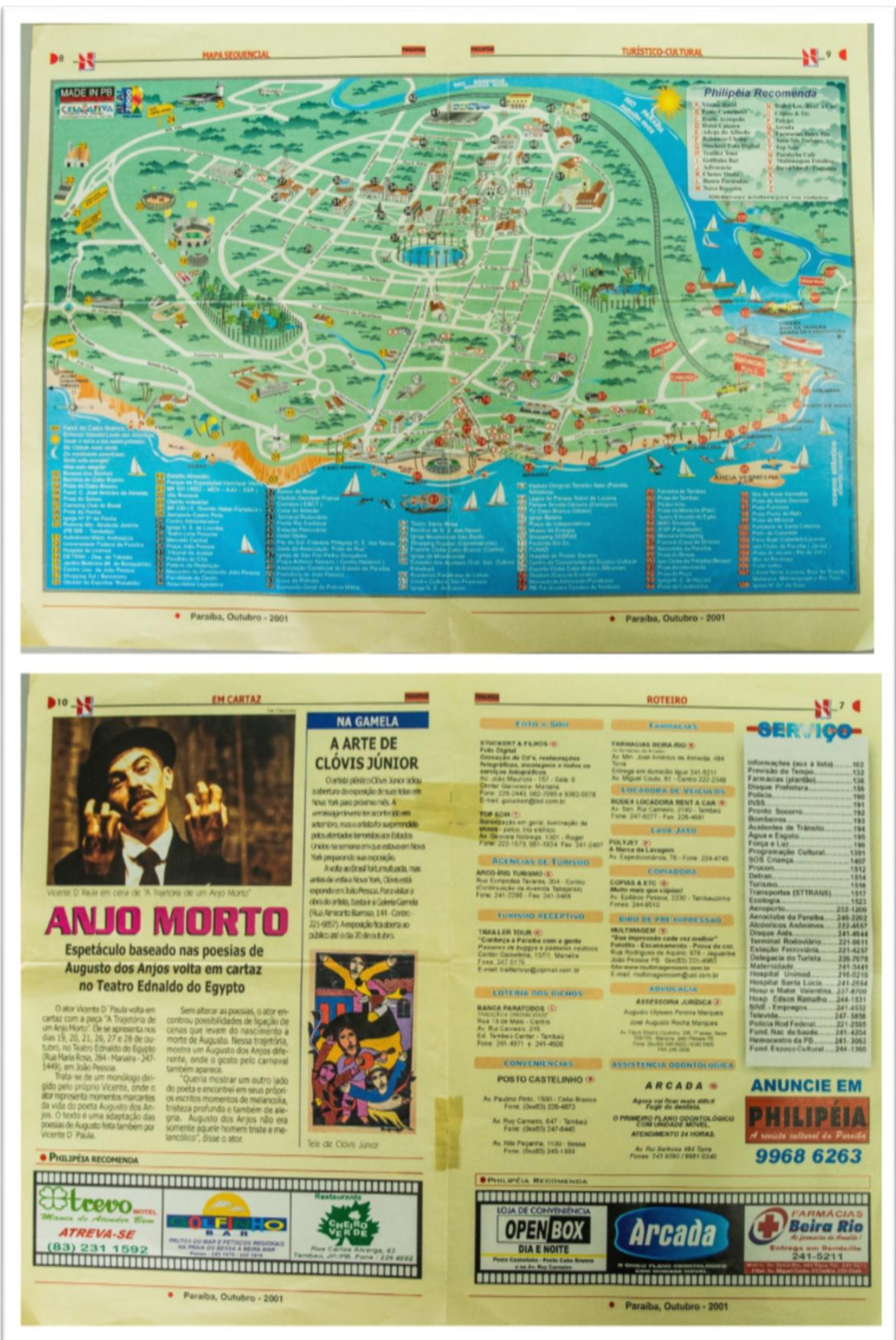

Mapa-Ficha 31 - Mapa seqüencial Turístico-Cultural. Encarte da Revista Philipéia. Data: 2001. 
Ficha 31 - Período/ano da publicação: Outubro de 2001.

Breve descrição: Mapa em destaque na cor verde. Mapa-encarte de uma revista de nome PHILIPÉIA.

Tipo de suporte (folder, encarte, para parede, etc): Encarte de revista.

Título do mapa: Mapa sequencial Turístico-Cultural.

Ponto de vista do observador (ou usuário do mapa): Visão de leste para oeste.

Foto da capa: Não tem capa.

Escala: Não consta.

Rosa dos ventos: Sim.

Os limites representados (ou as bordas do espaço representado pelo mapa):

Os limites na borda lateral direita do (norte o município) são: a ponta de Cabedelo, a Ilha da Restinga e a ponta de Costinha. Na borda lateral esquerda do mapa (sul de João Pessoa) os limites são a praia da Penha e mais acima a sudoeste do mapa, o contorno que limita os bairros Bancários e Mangabeira, e as proximidades do Distrito Industrial da cidade. A oeste e a noroeste do mapa o rio Sanhauá é o limite. Na borda inferior (leste) a faixa litorânea é o limite da representação do mapa.

Público alvo: Turistas em geral.

Slogans e/ou frases de efeito: Não identificado.

Topônimos citados: Basicamente ruas, sinalização com nomes de cidades e nomes de rios.

Instituição responsável por propor ou encomendar o mapa: Não identificada.

Empresa responsável pela execução do projeto, impressão do mapa: REAL 2000 Publicidade / Cria\&Ativa-Projetos Design / MADE IN PB - Movimento cultural.

Autor do mapa: Eduardo Stuckert. Finalização computação gráfica: Gilberto Stuckert Neto. 


\section{Ficha 32}

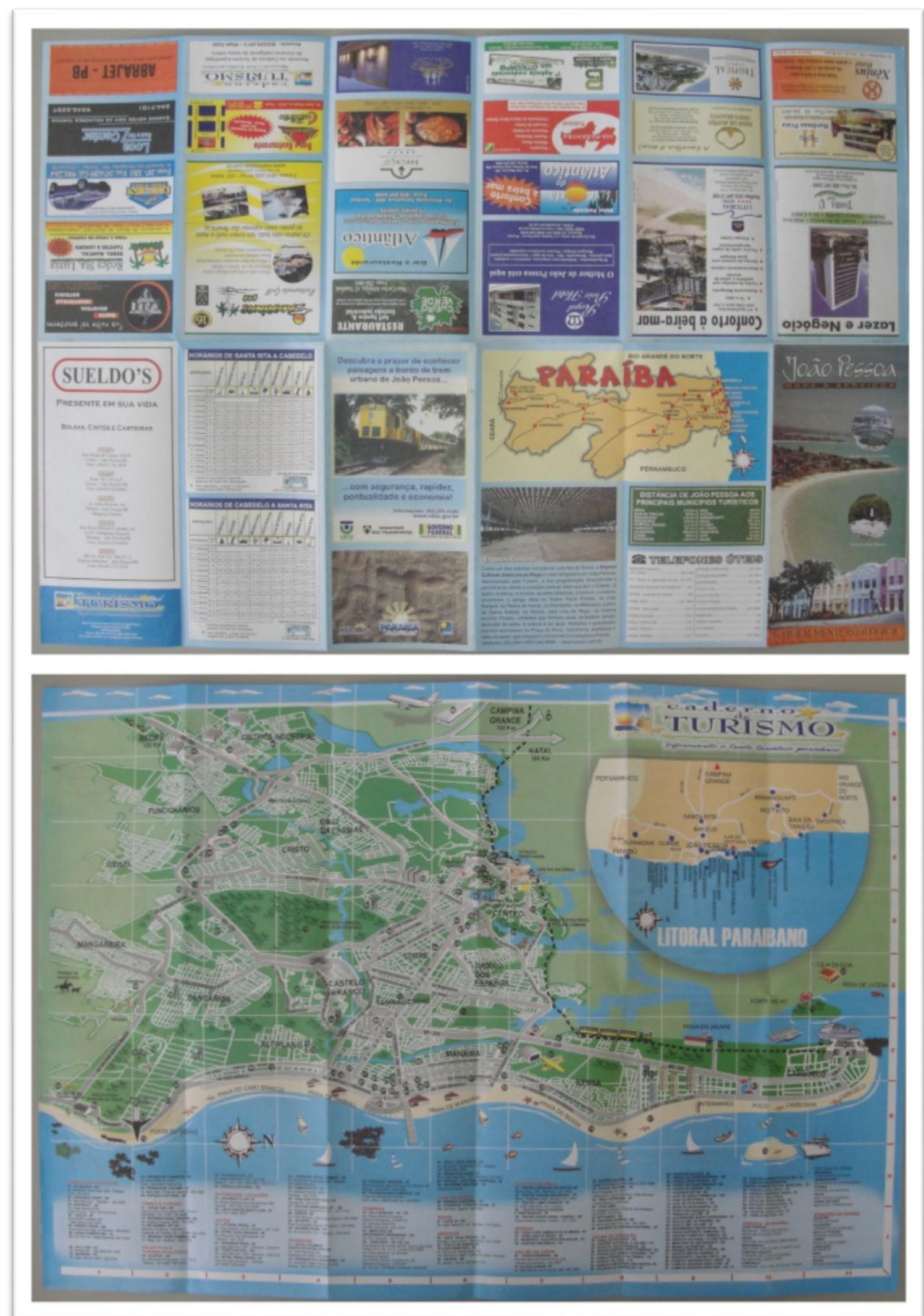

Mapa-Ficha 32 - Mapa turístico “João Pessoa, naturalmente ecológica”. Data: período provável 2001-2002. 
Ficha 32 - Período/ano de publicação: Aproximadamente do período 2001-2002.

Observações: São indicativos desta data de publicação os números dos telefones com apenas 3 dígitos iniciais. Além disso, consta um slogan do governo federal "Trabalhando em todo o Brasil" que foi do Governo de FHC de 1999-2002.

Breve descrição: Mapa turístico em formato de folder com forte apelo publicitário, apresentando muitas propagandas no verso. No interior do mapa também estão indexados pontos indicativos de estabelecimentos comerciais e de serviços. Constam também informações úteis: Telefones de emergência, Distância de JP aos principais municípios turísticos. Apresenta um mapa em tamanho menor do litoral da Paraíba na parte superior direita

Tipo de suporte (folder, encarte, para parede, etc): Folder

Título do folder: João Pessoa - Naturalmente Ecológica

Título do mapa: Não apresenta título.

Ponto de vista do observador (ou usuário do mapa): perspectiva de leste para oeste.

Foto da capa: A foto principal destaca a aérea da praia de Tambaú com destaque principal para a ponta da enseada onde se localiza o Hotel Tambaú. Existem duas fotos pequenas da Lagoa do Parque Solón de Lucena e do Farol do Cabo Branco, em formato de círculos e dispostas sobre esta foto maior. Abaixo, no rodapé da capa, aparece a fotografia do casario da Praça Antenor Navarro no Centro Histórico.

Base cartográfica anterior: Mapa com semelhanças aos mapas: Mapa 22 (ano aproximado 1999), Mapa 27 (de 2003), Mapa 28 (de 2000), Mapa 18 (de 1998) e Mapa 51 (de 2000). Consideramos este grupo de mapas como Base 01.

Escala: Não consta

Rosa dos ventos: Sim

Os limites representados (as bordas do espaço representado): Na borda inferior do mapa (leste da cidade) está o litoral iniciando do lado direito pela ponta de Cabedelo indo até a praia da Penha. Na borda esquerda do mapa (sul da cidade) o limite representado é o bairro de Mangabeira. No limite da borda superior (oeste) aparecem o Distrito Industrial e o Centro Histórico da cidade e na borda do lado direito do mapa (norte) o limite é a Ponta de Cabedelo e a praia de Lucena.

Público alvo: Turistas em geral.

Slogans e/ou frases de efeito: "Naturalmente ecológica".

Topônimos citados: Nomes das principais avenidas, nomes das principais praias localizadas desde Cabedelo até a Ponta de Seixas, Reserva Florestal Mata do Buraquinho, Viaduto do Oitizeiro, Parque Solon de Lucena (Lagoa), Parque Zoológico Arruda Câmara, Centro Histórico, Praia do Jacaré, Forte Velho, Igreja da Guia, Praia de Lucena, Farol do Cabo Branco, Igreja N. Sra da Penha, Detran.

Instituição responsável por propor ou encomendar o mapa: Governo do Estado. (consta logomarca do Governo do Estado)

Empresa responsável pela execução do projeto, impressão do mapa: Caderno de Turismo. Diretor: Fernando Duarte. Coordenador e Revisor: Léucio Laerte. Colaborador: Ronaldo Nóbrega. Editoração Eletrônica: Fernando D. Júnior.

Governador da época: José Targino Maranhão.

Autor do mapa: Não identificado. 


\section{Ficha 33}

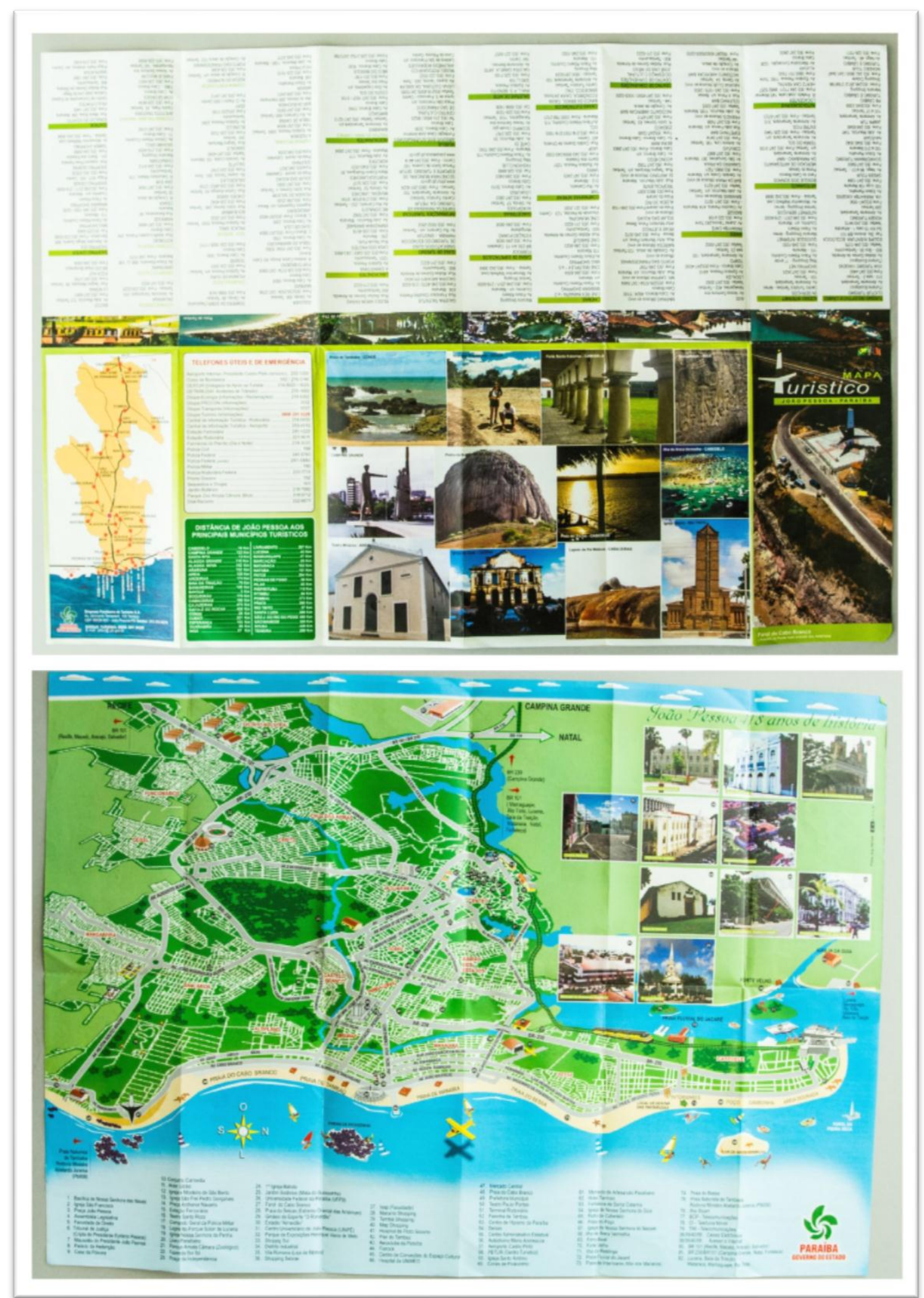

Mapa-Ficha 33 - Mapa turístico: “João Pessoa 418 anos de história”. Data: 2003. 
Ficha 33 - Período/ano de publicação: 2003.

Observações: Data presumida a partir da presença da publicidade das companhias aéreas Varig e Vasp que operaram no Brasil até o ano de 2005. Além desse indício, os números de telefones com 3 dígitos iniciais existiram até aproximadamente 2002. No entanto há apresença de alguns números de telefones celulares. A frase "João Pessoa 418 anos de história" dá a confirmação que o ano da publicação do mapa é 2003.

Interessante: Na capa, bem abaixo, consta a seguinte observação sobre o Farol do Cabo Branco: "Próximo ao ponto mais oriental das Américas".

Breve descrição: Mapa folder institucional com a logomarca do governo do estado/PBTUR. Apresenta no canto superior direito diversas fotografias de pontos turísticos numeradas e indexadas aos respectivos pontos no mapa.

No lado oposto do mapa apresenta outras fotografias de pontos de atração turística do Estado: Praia de Tambaba (Conde), Vale dos Dinossauros (Souza), Forte Santa Catarina (Cabedelo), Pedra de Itaquatiaras (Ingá), Açude Velho (Campina Grande), Pedra da Boca (Araruna), Praia do Jacaré e Ilha de Areia Vermelha (Cabedelo), Teatro Minerva (Areia), Igreja da Guia (Lucena), Lajedo do Pai Mateus (Cabaceiras), Igreja Matriz (Rio Tinto). Apresenta um mapa do Estado com a rede viária e as principais cidades. Apresenta tabela com telefones úteis de emergência e distâncias entre principais municípios turísticos. Apresenta quadro com orientações turísticas como restaurantes, bares, hotéis, Bancos, locadoras de automóveis, entre outros.

Tipo de suporte (folder, encarte, para parede, etc): Folder.

Título do Folder: Mapa Turístico - João Pessoa Paraíba.

Título do Mapa: João Pessoa 418 anos de história.

Ponto de vista do observador (ou usuário do mapa): Vista no sentido leste para oeste.

Foto da capa: Foto: tomada aérea do Farol do Cabo Branco

Escala: Não consta.

Rosa dos ventos: Sim.

Os limites representados (as bordas do espaço representado):

$\mathrm{Na}$ borda do lado leste está o litoral iniciando do lado direito pela ponta de Cabedelo indo até a praia da Penha.

Contornando a borda pelo lado Sul o limite representado pelo mapa é o bairro de Mangabeira.

$\mathrm{Na}$ borda oeste está o Distrito Industrial e na extremidade oeste o limite do mapa é o Centro Histórico da cidade.

Público alvo: Turistas em geral.

Slogans e/ou frases de efeito: "João Pessoa 418 anos de história"

"... ponto mais oriental das Américas"

Topônimos citados: Nomes dos bairros, Algumas praias, ilha de Areia Vermelha, Principais avenidas, Picãozinho, Igreja da Guia, Praia fluvial do Jacaré, Forte Velho, Farol da Pedra Seca (este ponto não é muito conhecido nem citado).

Instituição responsável por propor ou encomendar o mapa: Governo do Estado / PBTUR.

Empresa responsável pela execução do projeto, impressão do mapa: Não identificada. Governador da época: Cássio Cunha Lima.

Autor do mapa: Não identificado. 
Ficha 34

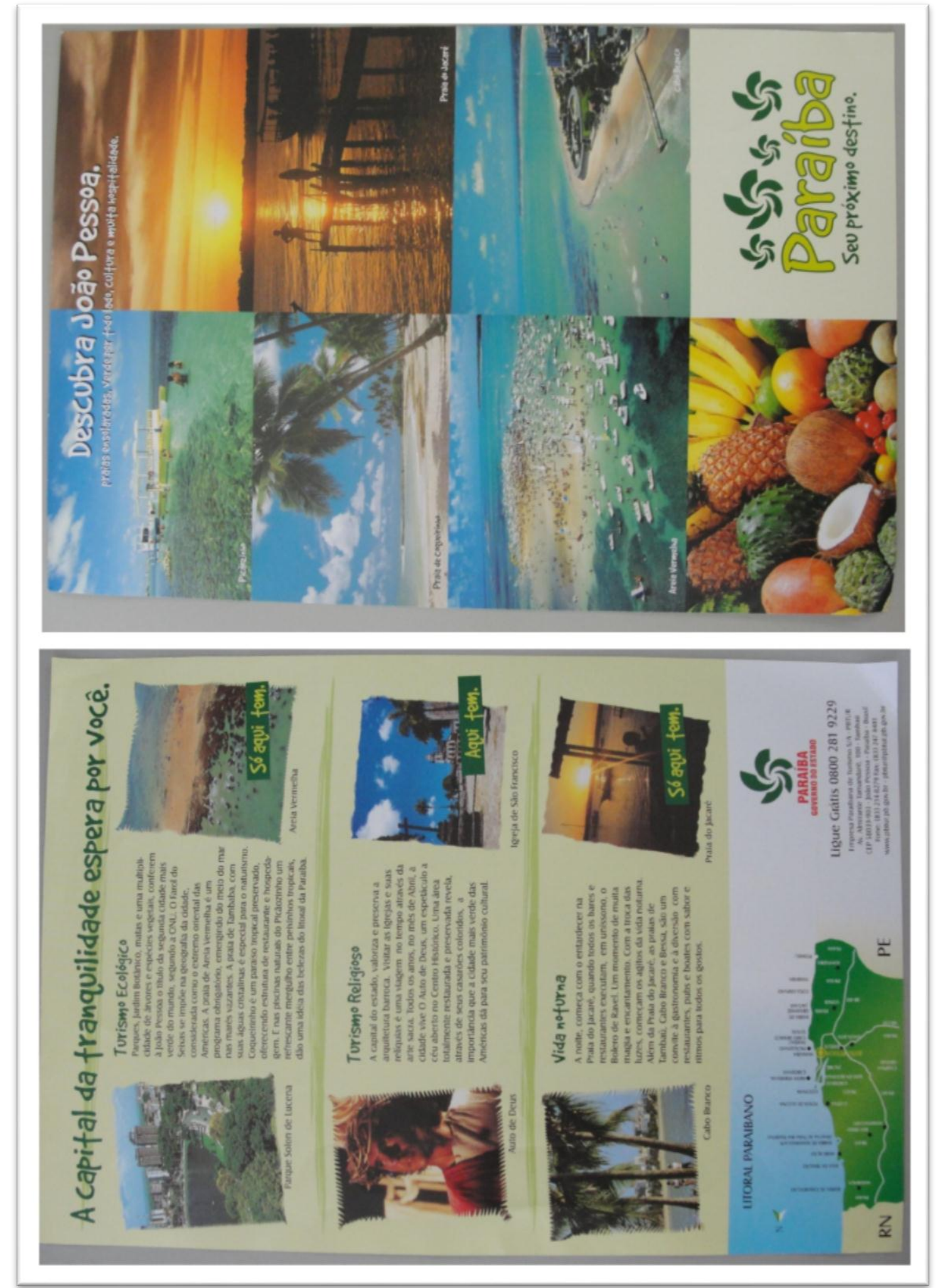

Mapa-Ficha 34 - Mapa turístico "Paraíba seu próximo destino”. Data: 2003. 
Ficha 34 - Período/Ano de publicação: 2003.

Observação: Data verificada através da presença da logomarca do Governo do Estado semelhante à um catavento e pelos números de telefones com 3 dígitos iniciais.

Breve descrição: Folheto destinado aos turistas com fotografias e algumas informações sobre pontos turísticos. Apresenta um mapa do litoral do estado com as principais cidades e praias.

Tipo de suporte (folder, encarte, para parede, etc): Folheto de publicidade turística.

Título do folder: Paraíba seu próximo destino.

Título do mapa: Litoral Paraibano.

Ponto de vista do observador (ou usuário do mapa): Vista vertical do litoral da Paraíba.

Foto da capa: Fotos de vários lugares turísticos: praia do Jacaré, Praia de Tambaú, Areia Vermelha, Picãozinho, Praia de Coqueirinho.

Escala: Não consta.

Rosa dos ventos: Apresenta indicação do Norte.

Os limites representados (as bordas do espaço representado): Vista do litoral do Estado. Público alvo: Turistas em geral.

Slogans e/ou frases de efeito: "Paraíba Seu próximo destino".

“... Segunda cidade mais verde do mundo...”.

“... extremo oriental das Américas".

"A capital da tranqüilidade espera por você"

"Descubra João Pessoa: praias ensolaradas, verde por todo canto, cultura e muita hospitalidade".

Instituição responsável por propor ou encomendar o mapa: Governo do Estado.

Empresa responsável pela execução do projeto, impressão do mapa: Não identificada.

Governador da época: Cássio Cunha Lima (2003 - 2007 / Reeleito 2007 - 2009)

Autor do mapa: Não identificado. 


\section{Ficha 35}

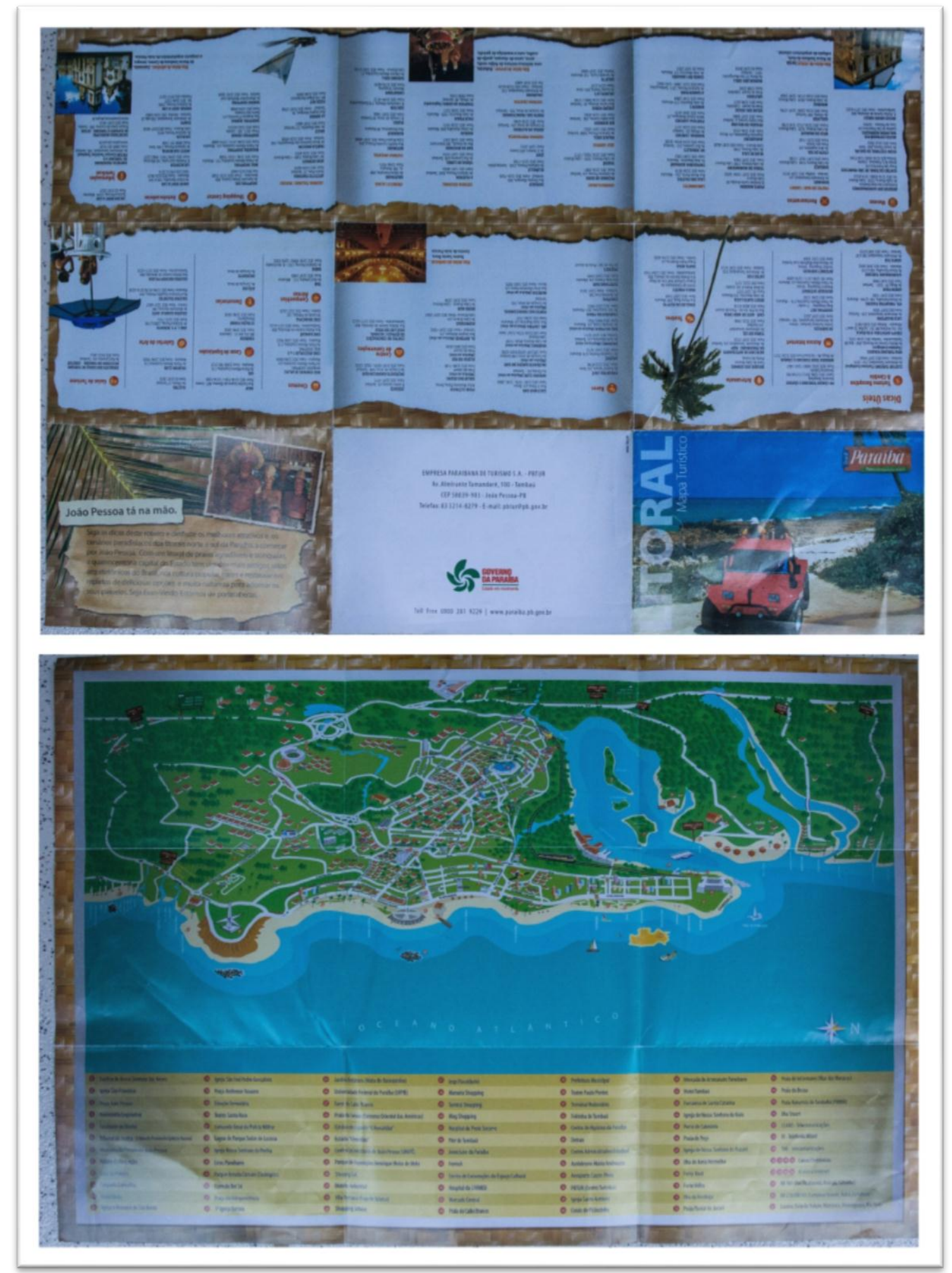

Mapa-Ficha 35 - Litoral Mapa turístico. Folder turístico do litoral com mapa da cidade de João Pessoa. Data: 2003. 
Ficha 35 - Período/Ano de publicação: 2003.

Observações: A data foi presumida de acordo com as referências existentes como a logomarca do Governo do Estado - Logomarca de um catavento e slogan: "Estado em movimento". Essas marcas foram utilizadas nos governos de Cássio Cunha Lima. O folder cita o Cine Banguê que parou de exibir filmes em meados de 2007 e só reabriu em 2009 e cita também o Cinema Municpal, além das operadoras Varig e Vasp que encerraram as atividades em 2006 e 2005 , respectivamente.

Breve descrição: Mapa folder dobrável. De um lado consta o mapa e, do outro lado, informações e referências turísticas.

Tipo de suporte (folder, encarte, para parede, etc): Folder.

Título do folder: Litoral Mapa Turístico.

Título do mapa: Não consta título.

Ponto de vista do observador: Perspectiva de visão de leste para oeste.

Foto da capa: Fotografia de um Bugre vermelho na beira de uma praia.

Escala: Não consta.

Rosa dos ventos: Sim.

Os limites representados (as bordas do espaço representado):

$\mathrm{Na}$ borda inferior Leste, todo o litoral do estado, desde Mataraca até as praias do litoral sul.

$\mathrm{Na}$ borda esquerda sul, as cidades de Pitimbu e Conde.

Na borda superior oeste, o Distrito Industrial, o Viaduto do Oitizeiro (Três Lagoas) e a

BR 101.

Na borda direita Norte, o município de Mataraca.

Público Alvo: Turistas em geral.

Slogans e/ou frases de efeito: "Paraíba Para conquistar você".

Topônimos citados: Principais ruas e bairros, Ruínas do Farol da Pedra Seca (pouco aparece nos mapas), Mataraca, Baía da Traição, Lucena, Ilha da Restinga, Ilha do Stuart, Forte Velho,

Instituição responsável por propor ou encomendar o mapa: Governo do Estado / PBTUR

Empresa responsável pela execução do projeto, impressão do mapa: MIX.

Governador da época: Cássio Cunha Lima [2003 - 2007 - reeleito 2007 - 2009]

Autor do mapa: Não identificado. 
Ficha 36

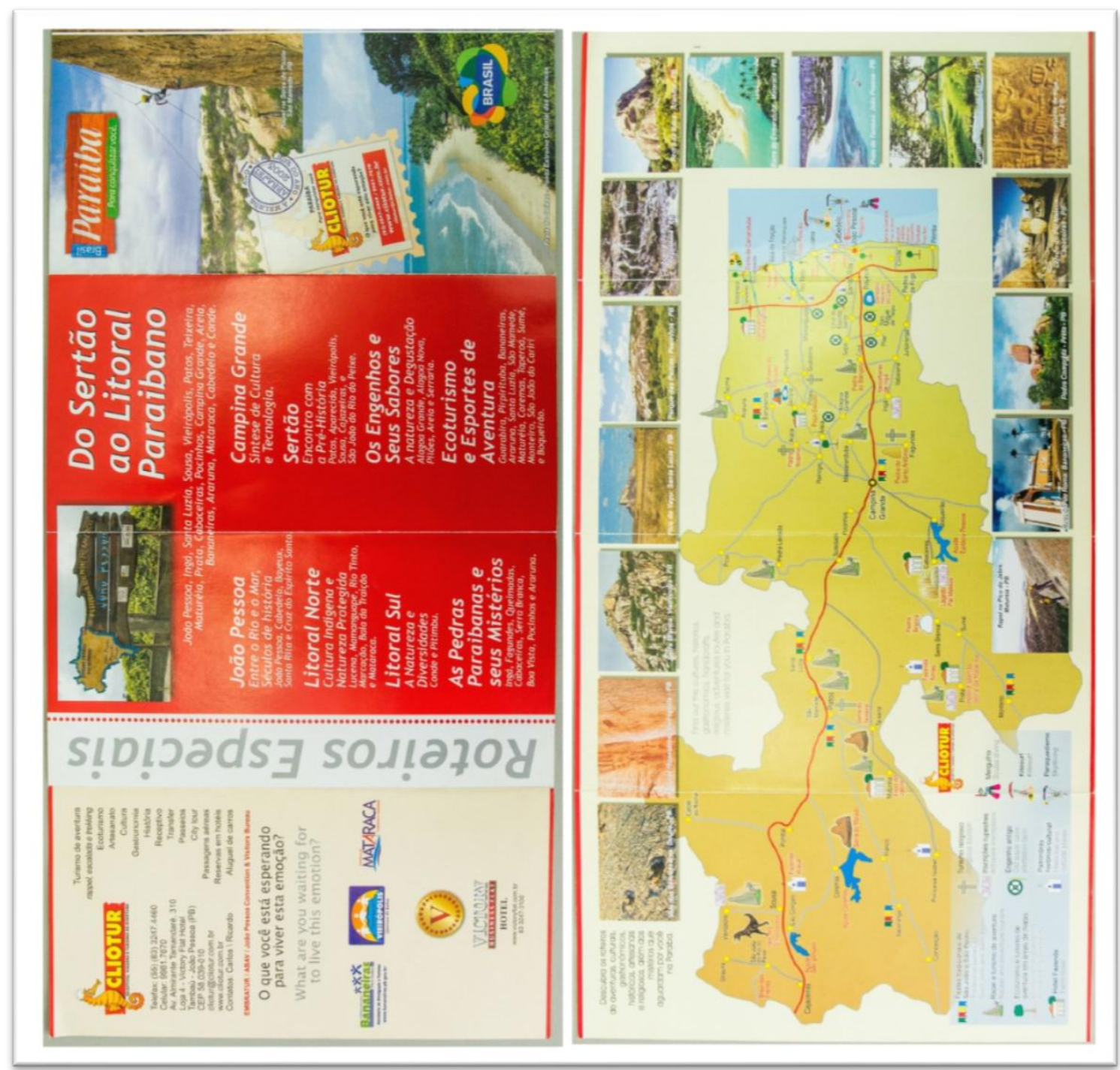

Mapa-Ficha 36 - Folder turístico "Paraíba para conquistar você”. Data: 2003. 
Ficha 36 - Período/ano de publicação: 2003.

Breve descrição: Folder dobrável com dois lados. Em um dos lados consta um mapa da Paraíba com a indicação, através de ícones, dos locais destacados para realização de turismo voltado para os seguintes temas: Festas tradicionais de São João e São Pedro, Rapel e turismo de aventura, Ecoturismo e turismo de aventura em locais de matas, Hotel Fazenda, Turismo Religioso, Inscrições Rupestres, Engenhos antigos, Patrimônio histórico e cultural, Mergulho, Kit Surfe, Pára-quedismo. Ao redor do mapa, semelhante à uma moldura, constam várias fotografias de diversos locais turísticos, tanto da capital do estado quanto do interior do Estado.

Tipo de suporte (folder, encarte, para parede, etc): Folder Dobrável

Título do folder: PARAÍBA - Para conquistar você

Título do mapa: Não consta.

Ponto de vista do observador: Vista vertical.

Foto da capa: Duas fotos: uma da praia do Seixas. A outra de uma pessoa fazendo rapel na Serra do Picote no município de São Mamede.

Escala: Não consta.

Rosa dos ventos: Não consta.

Os limites ou as bordas do espaço representado: Todo o Estado da Paraíba.

Público Alvo: Turistas nacionais e estrangeiros com interesses de roteiros especiais.

Slogans e/ou frases de efeito: "Paraíba para conquistar você"

"Praia do Seixas, ponto mais oriental das Américas".

Topônimos citados: MUNICÍPIOS seguidos dos pontos turísticos destacados: Mataraca (Camaratuba Hotel Fazenda, Barra de Camaratuba), Baía da Traíção, Lucena (Igreja da Guia e Forte Velho), Cabedelo, João pessoa (Areia Vermelha e Picãozinho), Pitimbu, Pedras de Fogo, Bayeux (Balneário Recanto do Lazer), Santa Rita, Rio Tinto (Projeto Peixe Boi), Mamanguape, Cruz do Espírito Santo, São Miguel de Taipu, Juripiranga, Pilar, Cajá (Pedra do Bangelo), Sapé, Itabaiana, Ingá (Itacoatiaras de Ingá), Fagundes (Pedra de Santo Antônio), Campina Grande, Guarabira, Pirpirituba (Cachoeira do Roncador), Tacima, Araruna, Bananeiras, Serraria, Pilões (Poço Escuro), Alagoa Grande, Areia, Massaranduba, Arara (Padre Ibiapina), Remígio, Pocinhos, Soledade, Pedra Lavrada, Picuí, Boqueirão (Açude Epitácio Pessoa), Cabaceiras (Lajedo Pai Mateus), Serra Branca (Pedra Branca), Sumé, Prata (Fazenda Almas e Hotel Fazenda da Matarina), Monteiro, Santa Luzia, São Mamede, Patos, Teixeira (Serra do Teixeira), Maturéia (Pico do Jabre), Princesa Isabel, Piancó, Coremas (Açude Coremas e Serra do Melado), Itaporanga, Conceição, Pombal (Fazenda Acauã), Sousa (Vale dos Dinossauros), São Gonçalo, Cajazeiras, São João do Rio do Peixe (Brejo das Freiras), Uiraúna, Vieirópolis, Catolé do Rocha.

Fotografias em destaque: Rapel no Pico do Jabre: Maturéia-PB / Cruzeiro de Roma: Bananeiras-PB / Pedra Comprida: Prata-PB / Lajedo do Pai Mateus: Cabaceiras-PB / Itacoatiaras de Ingá: Ingá-PB / Jardim Botânico: João Pessoa-PB / Praia de Tambaú: João Pessoa-PB / Barra de Camaratuba: Mataraca-PB / Pedra da Boca: Araruna-PB / Cachoeira do Roncador: Pirpirituba-PB / Parque das Pedras: Pocinhos-PB / Pico do Yayu: Santa Luzia-PB / Serra Branca: Vieirópolis-PB / Figuras Rupestres: Vieirópolis-PB / Vale dos Dinossauros: Sousa-PB.

Instituição responsável por propor ou encomendar o mapa: Prefeituras das cidades de Mataraca, Bananeiras e Vieirópolis e o Hotel Victory - Business Flat.

Empresa responsável pela execução do projeto, impressão do mapa: Não identificada. Autor do mapa: Não identificado. 


\section{Ficha 37}

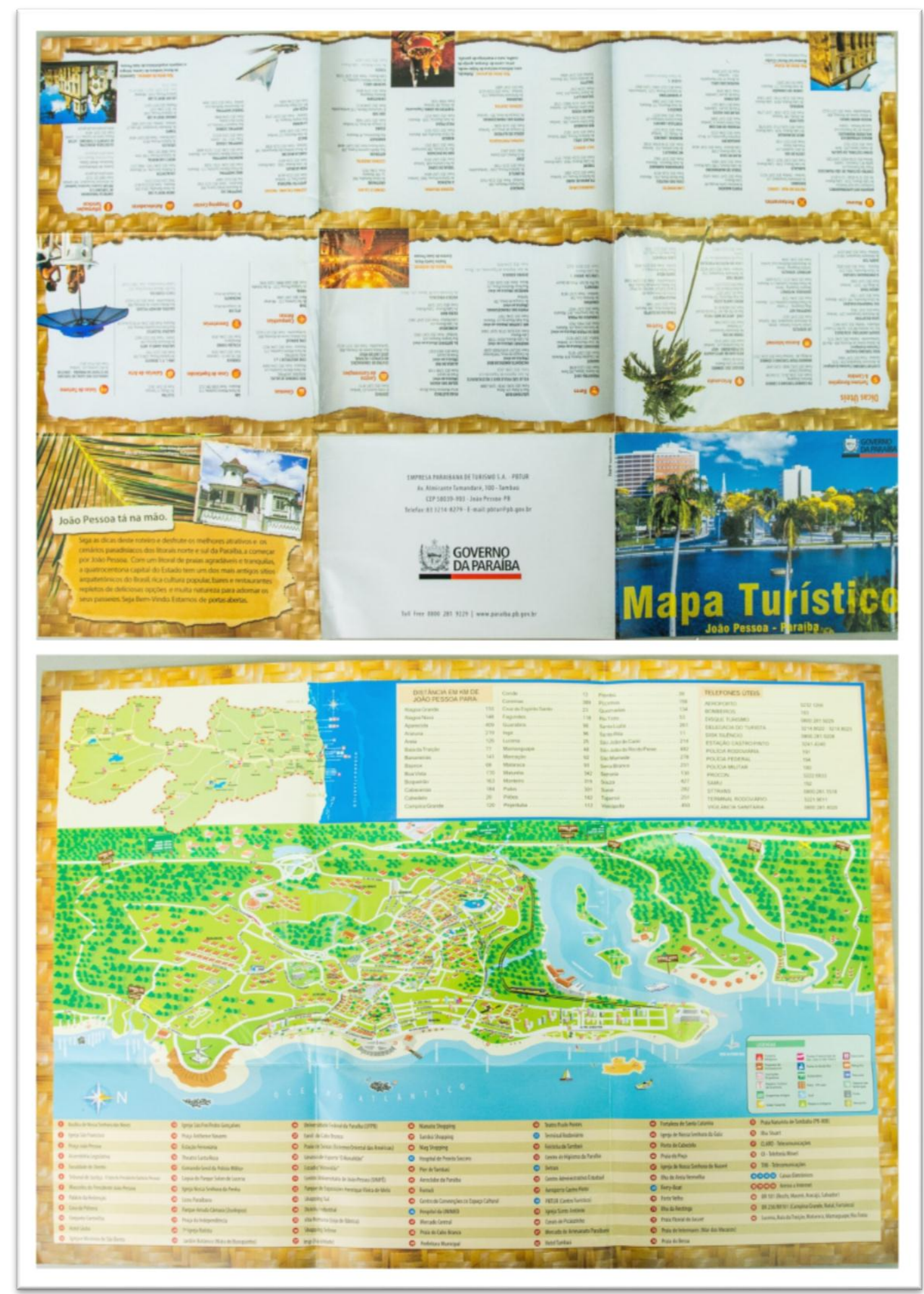

Mapa-Ficha 37 - Folder mapa do Governo do Estado. Título: "MapaTurístico João Pessoa-Paraíba”. Data 2004. 
Ficha 37 - Período/Ano de publicação: 2004.

Breve descrição: Mapa folder dobrável. De um lado consta o mapa e, do outro lado, informações e referências turísticas. Na parte superior do mapa foi acrescentado um mapa menor do Estado da Paraíba, uma tabela de distância entre João Pessoa e algumas cidades e uma lista de telefones úteis.

Tipo de suporte (folder, encarte, para parede, etc): Folder.

Título do folder: Mapa Turístico - João Pessoa Paraíba.

Título da mapa: Não consta.

Ponto de vista do observador (ou usuário do mapa): Vista no sentido de leste para oeste.

Foto da capa: Fotografia da Lagoa do Parque Solon de Lucena.

Escala: Não consta escala

Rosa dos ventos: Sim.

Os limites representados (as bordas do espaço representado):

$\mathrm{Na}$ borda inferior Leste, todo o litoral do estado, desde Mataraca até as praias do litoral sul.

Na borda esquerda sul, as cidades de Pitimbu e Conde.

$\mathrm{Na}$ borda superior oeste, o Distrito Industrial, o Viaduto do Oitizeiro (Três Lagoas) e a BR 101.

Na borda direita Norte, o município de Mataraca.

Público Alvo: Turistas em geral.

Slogans e/ou frases de efeito: "João Pessoa tá na mão".

Topônimos citados: Principais ruas e bairros, Ruínas do Farol da Pedra Seca (pouco aparece nos mapas), Mataraca, Baía da Traição, Lucena, Ilha da Restinga, Ilha do Stuart, Forte Velho,

Instituição responsável por propor ou encomendar o mapa: Governo do Estado.

Empresa responsável pela execução do projeto, impressão do mapa: Não identificada.

Governador da época: Cássio Cunha Lima

Autor do mapa: Não identificado. 
Ficha 38

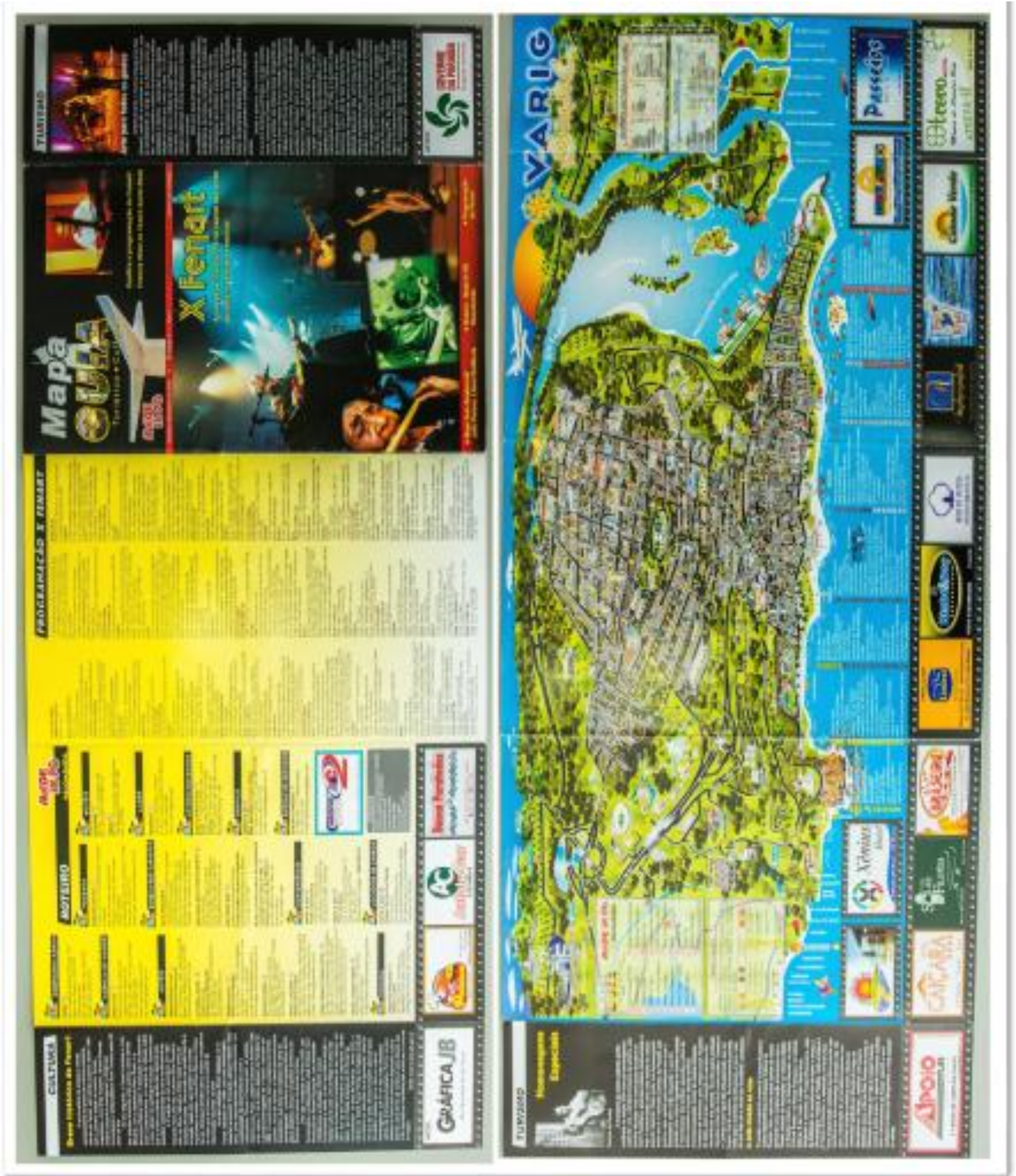

Mapa-Ficha 38 - Mapa Guia Turístico Cultural X FENART. Data: Nov. 2004. 
Ficha 38 - Período/ano da publicação: Novembro de 2004.

Breve descrição: Mapa-Guia turístico em formato de folder dobrável impresso dos dois lados. No interior do mapa consta um mapa principal da Cidade de João Pessoa e, no lado oposto ao mapa, estão a capa do folder, a programação cultura do período, e algumas publicidades.

Criador do Folder: Eduardo Stuckert, Editor: Elinaldo Rodrigues, Programação visual/Edição: Cláudio Soares.

Tipo de suporte (folder, encarte, para parede, etc): Folder.

Título do folder: Mapa Guia Turístico Cultural.

Título do mapa: Não consta.

Ponto de vista do observador: Vista sentido de leste para oeste.

Foto da capa: Foto atrações do X Fenart.

Escala: Não consta..

Rosa dos ventos: Sim.

Os limites representados (ou as bordas do espaço representado pelo mapa): Os limites na borda lateral direita do (norte o município) são: a ponta de Cabedelo, a Ilha da Restinga e a ponta de Costinha. Na borda lateral esquerda do mapa (sul de João Pessoa) os limites são a praia da Penha e mais acima a sudoeste do mapa, o contorno que limita os bairros Bancários e Mangabeira, e as proximidades do Distrito Industrial da cidade. A oeste e a noroeste do mapa o rio Sanhauá é o limite. Na borda inferior (leste) a faixa litorânea é o limite da representação do mapa.

Público alvo: Turistas em geral.

Slogans e/ou frases de efeito: "Farol do Cabo Branco extremo oriental das Américas, onde o sol e a lua nascem primeiro na cidade mais verde do continente Americano". "Viva essa energia, sinta essa alegria".

Principais pontos ou locais destacados: Forte de Cabedelo, Farol do Cabo Branco, Lagoa, Hotel Tambaú.

Topônimos citados: todas as praias desde a Barra de Guaju no litoral norte, até a praia de Coqueirinhos no sul. Principais ruas e avenidas da cidade. Rios: Sanhauá, Paraíba, Mamanguape.

Instituição responsável por propor ou encomendar o mapa: Prefeitura Municipal.

Empresa responsável pela execução do projeto, impressão do mapa: Gráfica JB.

Autor do mapa: Eduardo Stuckert. 


\section{Ficha 39}

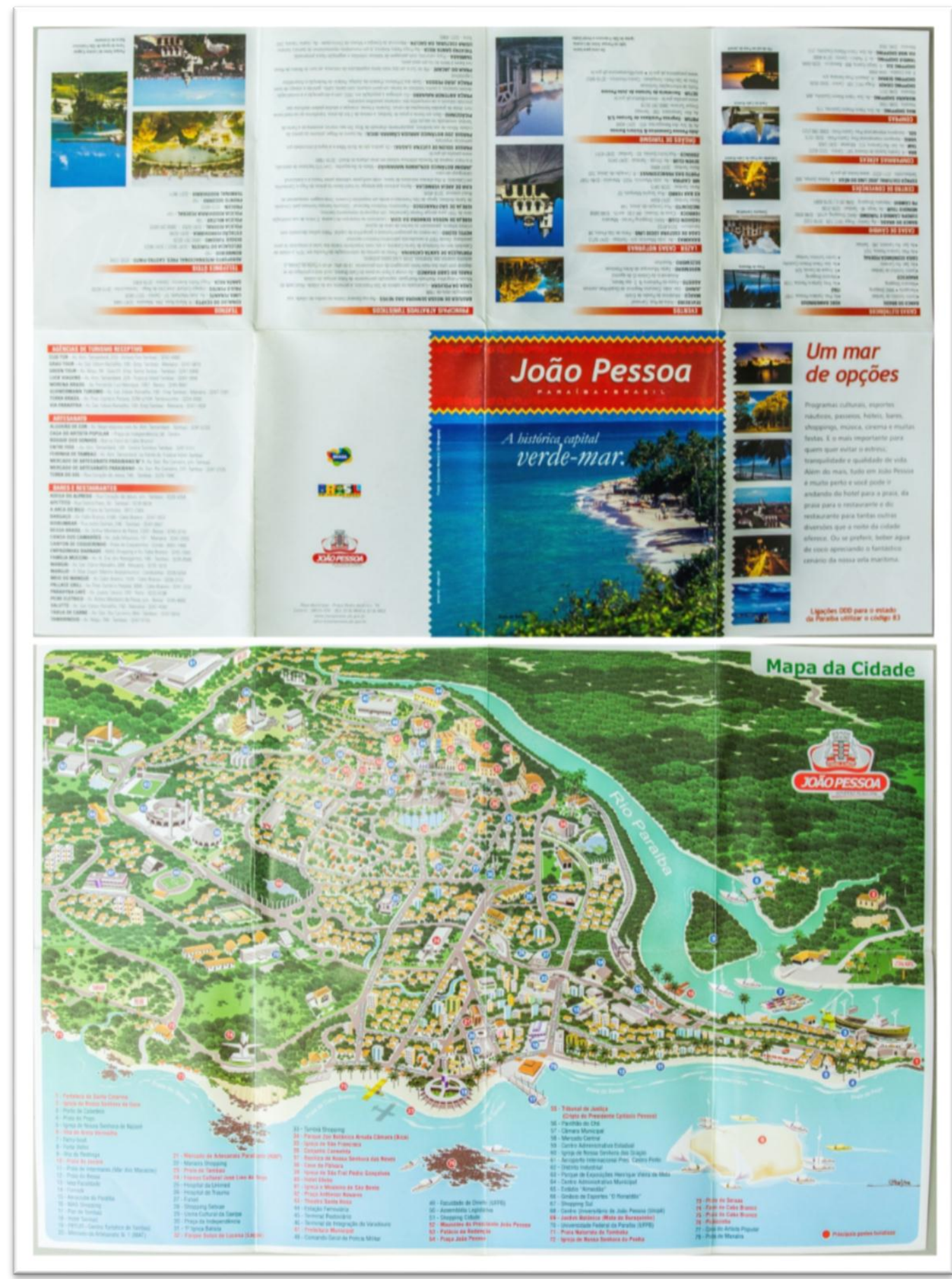

Mapa-Ficha 39 - João Pessoa a histórica capital verde mar. Data 2005. 
Ficha 39 - Período/ano de publicação: 2005.

Observação: Data presumida através da logomarca do Governo Federal: BRASIL um país de todos.

Breve descrição: Folder institucional dobrável com mapa da cidade. No verso do mapa constam várias informações turísticas como, lista de pontos turísticos com uma breve descrição de cada um. Constam algumas fotografias em tamanho pequeno de vários locais turísticos da cidade como, a Lagoa, a Igreja de São Francisco e a Barra de Gramame.

Tipo de suporte (folder, encarte, para parede, etc): Folder dobrável.

Título do folder: João pessoa - A histórica capital verde mar.

Título do mapa: Mapa da cidade.

Ponto de vista do observador (ou usuário do mapa): Vista no sentido de leste para oeste.

Foto da capa: Ponta de Seixas (Foto: Gustavo Moura e Zé Marques).

Escala: Não consta.

Rosa dos ventos: Não consta.

Os limites representados (as bordas do espaço representado):

$\mathrm{Na}$ borda inferior (Leste): a faixa da costa com as praias que vai do litoral de Cabedelo até a praia de Tambaba.

$\mathrm{Na}$ borda lateral esquerda (Sul): o contorno do bairro de Mangabeira e o Distrito Industrial;

Na borda superior (Oeste): Aeroporto Castro Pinto e o Rio Sanhauá.

$\mathrm{Na}$ borda lateral direita (Norte): O rio Sanhauá, Forte Velho, a Igreja da Guia e o município de Cabedelo.

Público Alvo: Turistas em geral.

Slogans e/ou frases de efeito: "Ponta de Seixas o ponto mais oriental das Américas, onde o sol nasce primeiro"

Topônimos citados: Nomes das principais avenidas, Rio Paraíba, Praia do Poço, Intermares, Bessa, Tambaú, Cabo Branco, Seixas, Tambaba, BR 101, BR 230, os demais topônimos estão em legenda na parte inferior do mapa.

Instituição responsável por propor ou encomendar o mapa: Prefeitura Municipal de João Pessoa.

Empresa responsável pela execução do projeto, impressão do mapa: Antares / AbapPB.

Prefeito da época: Ricardo Coutinho

Autor do mapa: Gilton Lira (Apresenta assinatura no mapa). 
Ficha 40

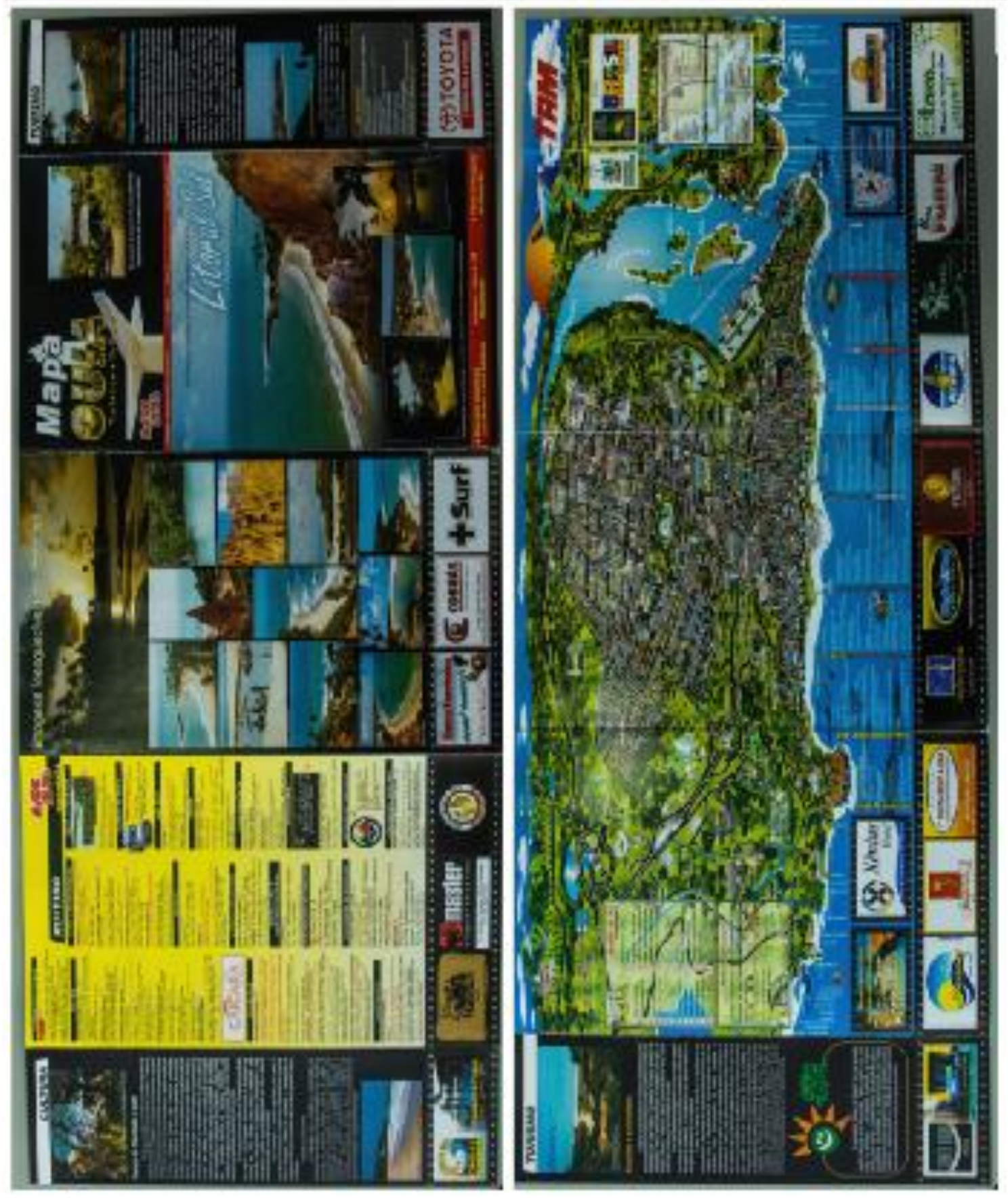

Mapa-Ficha 40 - Mapa Guia Turístico Cultural - Na Paraíba, conforto e aventura entre as praias do Litoral Sul. Data Dez. 2006/Jan. 2007. 
Ficha 40 - Período/ano da publicação: dezembro de 2006 / janeiro de 2007

Breve descrição: Mapa-Guia turístico em formato de folder dobrável impresso dos dois lados. No interior do mapa consta um mapa principal da Cidade de João Pessoa. No lado oposto ao mapa estão a capa do folder, a programação cultural do período, e algumas publicidades

Tipo de suporte: Folder

Título do folder: Mapa-Guia turístico Cultural: Litoral Sul

Título do mapa: Não consta título no mapa.

Ponto de vista do observador (ou usuário do mapa): Ponto de vista de leste para oeste.

Foto da capa: Fotografia das praias do litoral sul.

\section{Base cartográfica anterior:}

Escala: Não consta.

\section{Rosa dos ventos: Sim.}

Os limites representados (ou as bordas do espaço representado pelo mapa): Os limites na borda lateral direita do (norte o município) são: a ponta de Cabedelo, a Ilha da Restinga e a ponta de Costinha. Na borda lateral esquerda do mapa (sul de João Pessoa) os limites são a praia da Penha e mais acima a sudoeste do mapa, o contorno que limita os bairros Bancários e Mangabeira, e as proximidades do Distrito Industrial da cidade. A oeste e a noroeste do mapa o rio Sanhauá é o limite. Na borda inferior (leste) a faixa litorânea é o limite da representação do mapa.

Público alvo: Turistas em geral

Slogans e/ou frases de efeito: "Ponto extremo oriental das Américas, onde o sol nasce primeiro". "Extremo oriental leste das Américas, onde o sol e a lua raiam primeiro na cidade mais verde do continente Americano", "Viva essa energia", "Sinta essa alegria".

Principais pontos ou locais destacados: Forte de Cabedelo, Farol do Cabo Branco, Lagoa, Hotel Tambaú.

Topônimos citados: Rio Paraíba e Rio do Cabelo, Sanhauá, Constam também os nomes das principais ruas e avenidas.

Instituição responsável por propor ou encomendar o mapa: Prefeitura Municipal.

Empresa responsável pela execução do projeto, impressão do mapa: Gráfica JB

Autor do mapa: Rodolfo Stuckert. 


\section{Ficha 41}

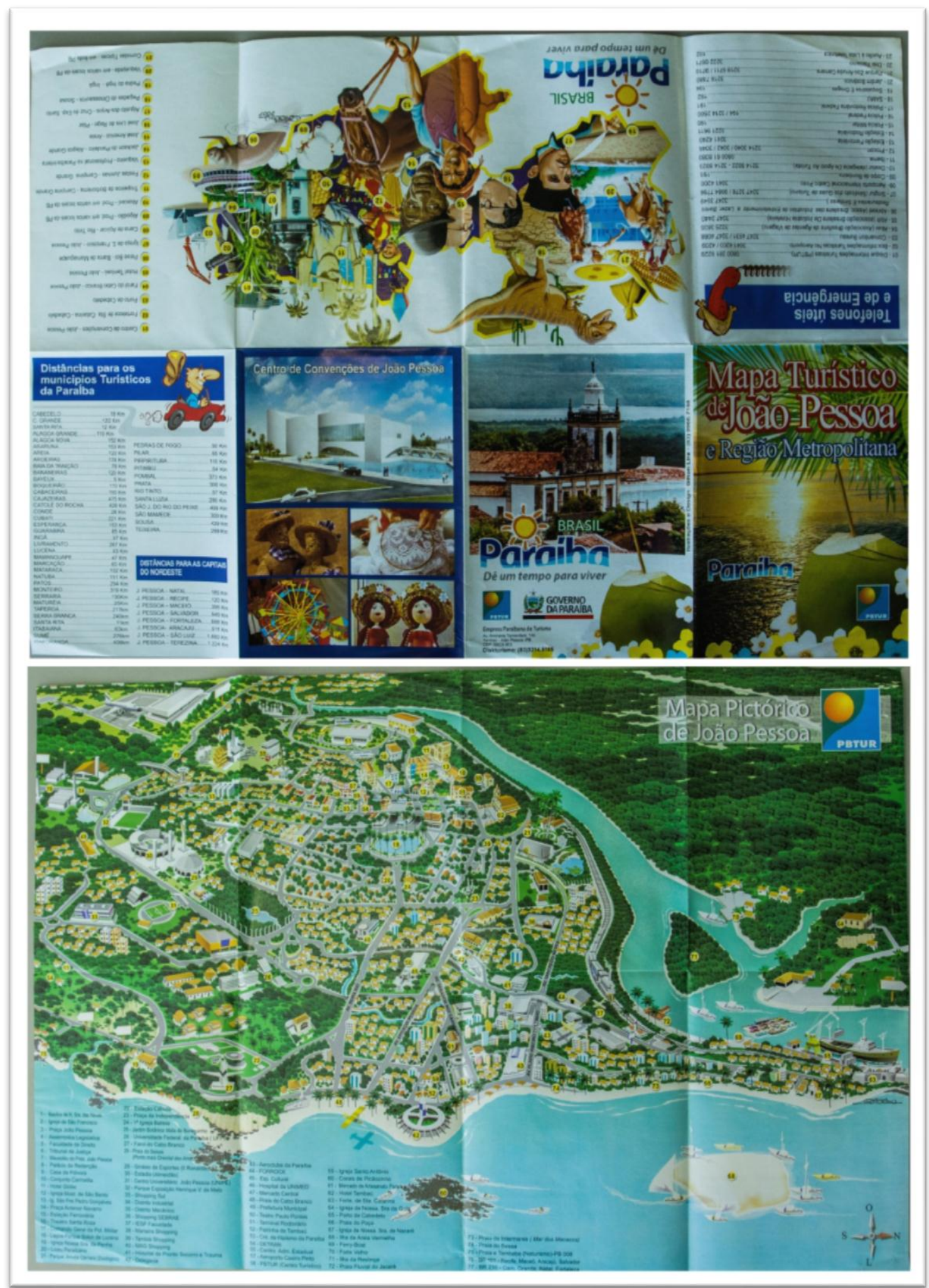

Mapa-Ficha 41 - Mapa turístico de João Pessoa e Região Metropolitana. Data: 2007. 
Ficha 41 - Período/ano de publicação: 2007.

Breve descrição: Folder institucional dobrável com mapa da cidade. No verso do mapa constam várias informações turísticas como, telefones úteis, distâncias para os municípios turísticos da Paraíba, distâncias para as capitais do Nordeste. Apresenta também algumas fotografias e uma arte de Gilton Lira que ilustra algumas personalidades e locais turísticos do Estado.

Tipo de suporte: (folder, encarte, para parede, etc): Folder.

Título dofolder: Mapa Turístico de João Pessoa e Região Metropolitana.

Título do mapa: Mapa pictórico de João Pessoa.

Ponto de vista do observador (ou usuário do mapa): Vista do sentido de leste para oeste.

Foto da capa: o mar, uma folha de coqueiro e um côco.

Escala: Não consta.

Rosa dos ventos: Sim.

Os limites representados (as bordas do espaço representado):

$\mathrm{Na}$ borda inferior (Leste): a faixa da costa com as praias que vai do litoral de Cabedelo até a praia de Tambaba.

$\mathrm{Na}$ borda lateral esquerda (Sul): o contorno do bairro de Mangabeira e o Distrito Industrial;

Na borda superior (Oeste): Aeroporto Castro Pinto e o Rio Sanhauá.

$\mathrm{Na}$ borda lateral direita (Norte): O rio Sanhauá, Forte Velho, a Igreja da Guia e o município de Cabedelo.

Público Alvo: Turistas em geral.

Slogans e/ou frases de efeito: "Paraíba, dê um tempo para viver".

Topônimos citados: Poucas avenidas: Av. Beira Rio, Av. Epitácio Pessoa, Av. Senador Rui Carneiro, Av. Flávio Ribeiro Coutinho e Av. Trancredo Neves.

Instituição responsável por propor ou encomendar o mapa: Governo do Estado da Paraíba / PBTUR

Empresa responsável pela execução do projeto, impressão do mapa: Não identificada. Governador da época: Cássio Cunha Lima

Autor do mapa: Gilton Lira (Consta assinatura). 


\section{Ficha 42}

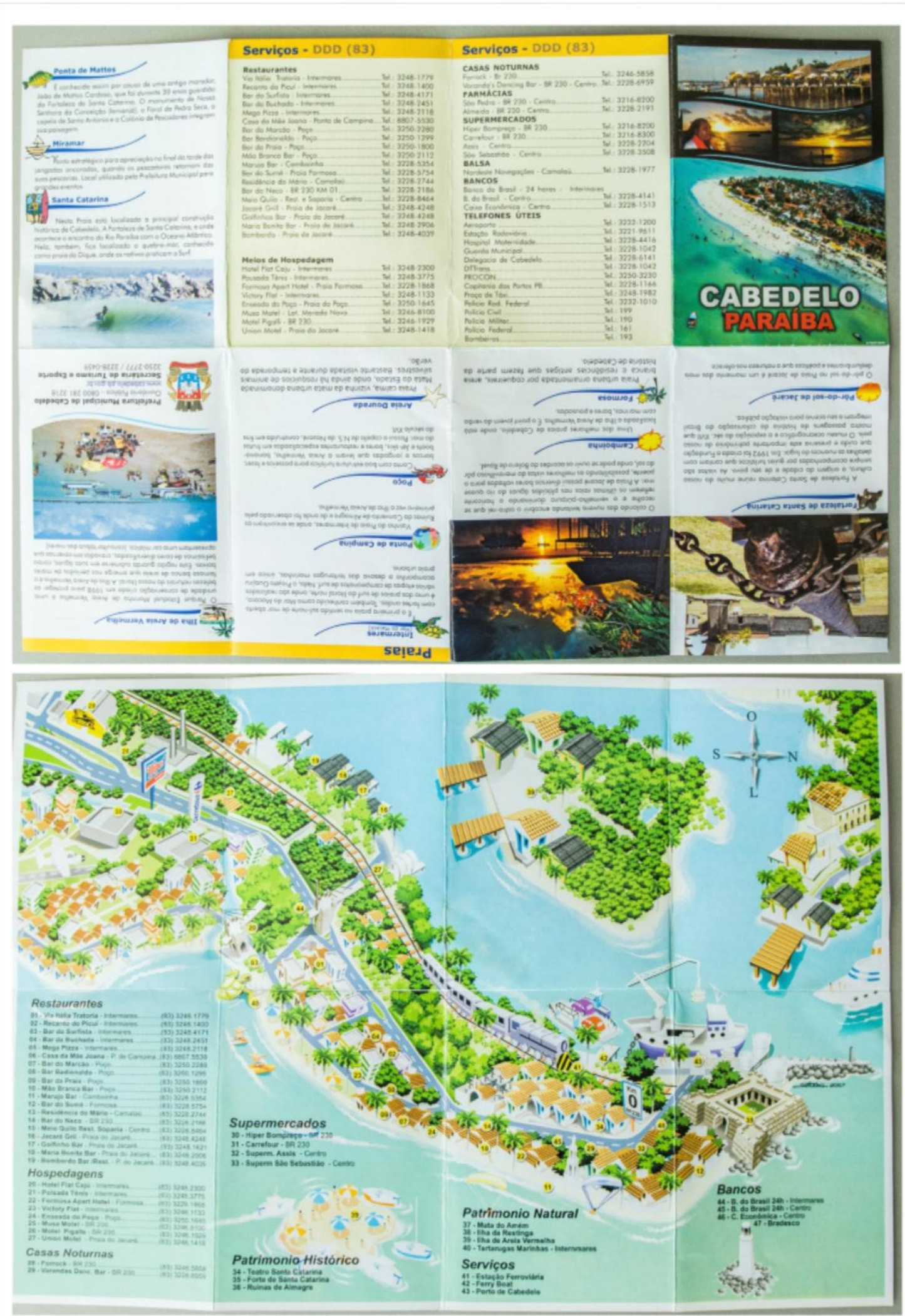

Mapa-Ficha 42 - Mapa da cidade de Cabedelo - Paraíba. Data 2007. 
Ficha 42 - Período/Ano de publicação: 2007.

Breve descrição: Mapa na forma de folder institucional da Prefeitura Municipal e Secretaria de Turismo do município. Apresenta um mapa em um dos lados da publicação e do outro lado algumas fotos e informações turísticas, além de textos explicativos para os principais pontos turísticos da cidade. Apresenta um mapa pictórico da cidade de Cabedelo que mapeia desde o supermercado Hiperbompreço até a Igreja da Guia e o início da ponta de Costinha.

Tipo de suporte: (folder, encarte, para parede, etc): Folder institucional.

Título do folder: Cabedelo - Paraíba.

Título do mapa: Não consta título.

Ponto de vista do observador (ou usuário do mapa): Perspectiva de visão de leste para oeste.

Foto da capa: Algumas fotos. A principal e maior é a foto aérea da ponta de Cabedelo. As demais são do pôr do sol da praia do Jacaré e dos bares da praia do jacaré.

Escala: Não consta.

Rosa dos ventos: Sim.

Os limites representados (as bordas do espaço representado): Representa a ponta de Cabedelo desde o supermercado Hiperbompreço até a Ponta de Costinha.

Público Alvo: Turistas em geral.

Slogans e/ou frases de efeito: Não constam.

Topônimos citados: Não cita topônimos. Os locais são indicados através de numeração e legenda.

Instituição responsável por propor ou encomendar o mapa: Prefeitura Municipal da cidade de Cabedelo / Secretaria de Turismo e Esporte.

Empresa responsável pela execução do projeto, impressão do mapa: Não identificada. Autor do mapa: Gilton Lira. 


\section{Ficha 43}

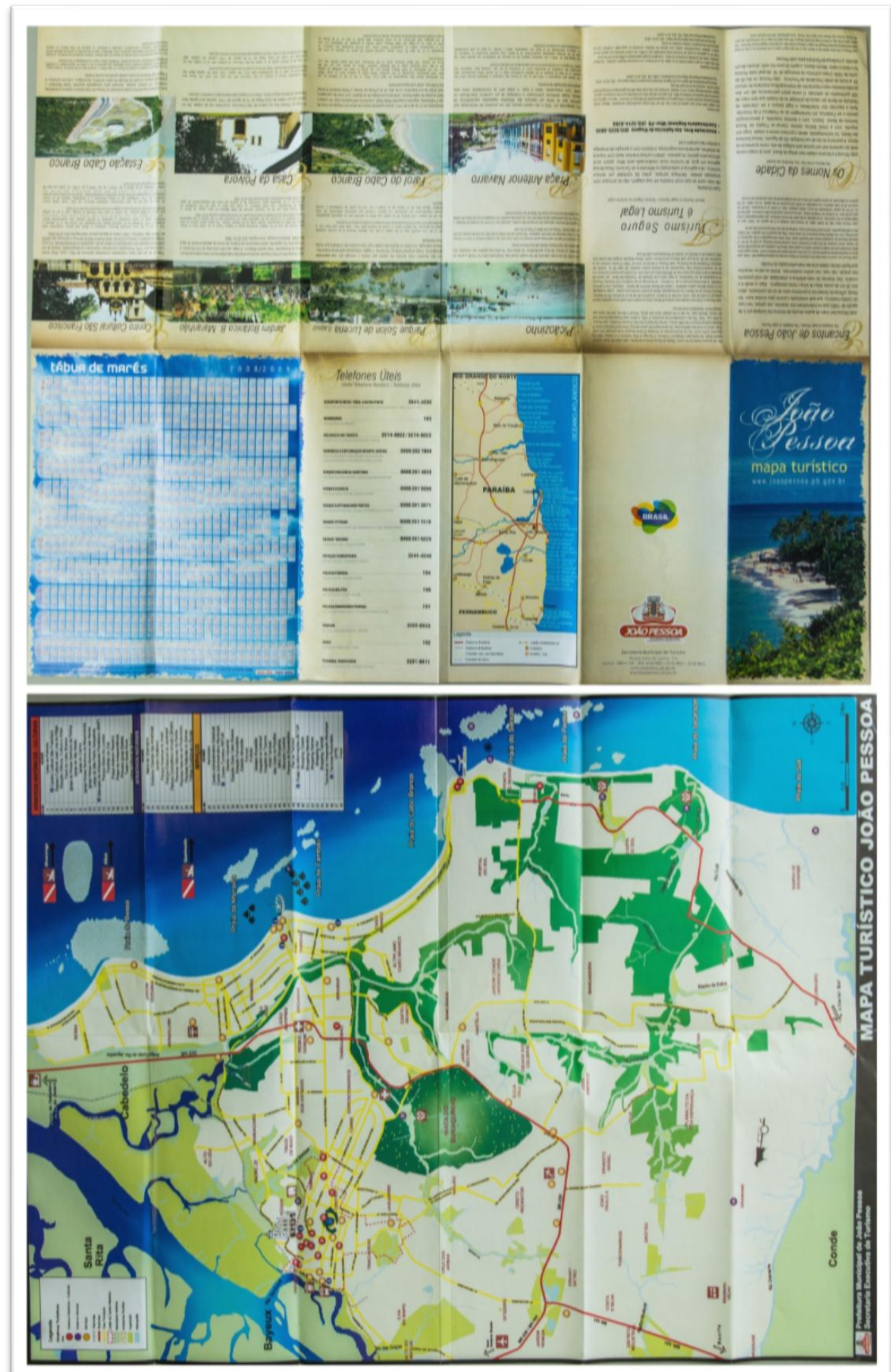

Mapa-Ficha 43 - Mapa Turístico João Pessoa. Data 2008. 
Ficha 43 - Período/Ano de publicação: 2008.

Observação: Data verificada através da tábua das marés anexa ao folder.

Breve descrição: Mapa folder institucional da cidade de João Pessoa. Apresenta o mapa em um dos lados e, no outro, informações gerais sobre a cidade. Possui texto explicativo sobre a história e as características da cidade com tradução para o inglês e o espanhol, com destaque para os principais pontos turísticos. Possui a tábua das marés e lista com telefones úteis.

Tipo de suporte: (folder, encarte, para parede, etc): Folder institucional da Prefeitura Municipal.

Título do folder: João Pessoa Mapa turístico.

Título do mapa: Mapa Turístico João Pessoa.

Ponto de vista observador (ou usuário do mapa): Tomada vertical.

Foto da capa: Foto de uma ponta de praia com muitos coqueiros e vegetação

Escala: Consta escala gráfica.

Rosados ventos: Sim.

Os limites representados (as bordas do espaço representado):

$\mathrm{Na}$ borda inferior (Sul) os limites são o município do Conde e a Barra de Gramame.

$\mathrm{Na}$ borda lateral esquerda (Oeste) estão os bairros: Distrito Industrial. Jardim Veneza a Ilha do Bispo e o município de Bayeux.

Na borda superior (Norte) estão os municípios de Santa Rita e Cabedelo.

$\mathrm{Na}$ borda lateral direita (Leste) está o Oceano e toda linha de costa da cidade, iniciando ao norte no município de Cabedelo e terminando na Praia do Sol.

Público Alvo: Turistas em geral

Slogans e/ou frases de efeito: “... A ponta de Seixas traz os primeiros raios de sol do continente"

Topônimos citados: Bairros, principais avenidas, praias, rios, cidades vizinhas, a Mata do Buraquinho,

Instituição responsável por propor ou encomendar o mapa: Prefeitura Municipal de João Pessoa / Secretaria Executiva de Turismo

Empresa responsável pela execução do projeto, impressão do mapa: Não identificada. Autor do mapa: Não identificado. 


\section{Ficha 44}

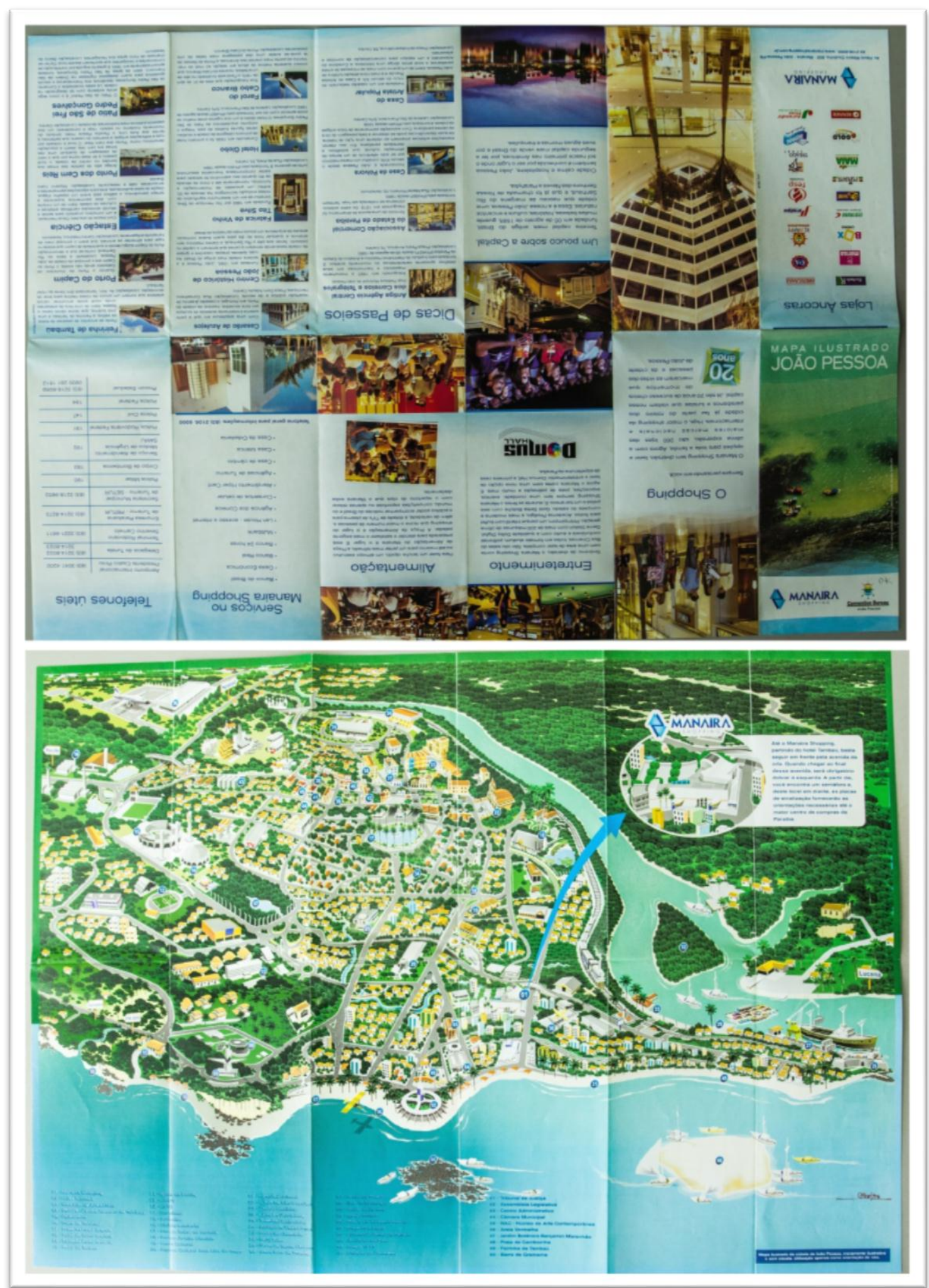

Mapa-Ficha 44 - Mapa ilustrado João Pessoa. Folder publicitário do Manaíra Shopping. Data 2009. 
Ficha 44 - Período/Ano de publicação: 2009.

Observações: Data presumida pela informação dos 20 anos do Shopping Manaíra cuja inauguração foi em 1989.

Interessante: Neste mapa aparece a Estação Ciências.

Aparece o slogan de maneira "errada": "A segunda capital mais verde do Brasil".

Breve descrição: Material publicitário do Manaíra Shopping em formato de folder com um mapa da cidade em um dos lados e fotografias e informações turísticas do outro. Constam informações sobre serviços disponibilizados pelo Shopping, Lista de telefones úteis e dicas de passeios com breve descrição e pequena fotografia dos seguintes locais: Antiga agência central dos correios e telégrafos, prédio da Antiga Associação Comercial da Paraíba, Casa da Pólvora, Casa do Artista Popular, O Casarão dos Azulejos, Centro Histórico de João Pessoa, Fábrica de vinhos Tito Silva, Hotel Globo, Farol do Cabo Branco, Feirinha de Tambaú, Porto do Capim, Estação Ciências, Ponto de Cem Réis, Pátio de São Frei Bento Gonçalves.

Observação: Todos os locais mapeados são indexados no mapa através de numeração acompanhada de uma legenda na parte inferior do mapa com os nomes de todos os lugares destacados.

Tipo de suporte (folder, encarte, para parede, etc): Folder publicitário do Manaíra Shopping.

Título do folder: Mapa Ilustrado JOÃO PESSOA

Título do mapa: Não consta título no mapa.

Ponto de vista do observador (ou usuário do mapa): Visão de leste para oeste.

Foto da capa: Foto aérea de Picãozinho de Dirceu Tortorelo.

Escala: Não consta.

Rosa dos ventos: Não consta.

Os limites representados (as bordas do espaço representado):

Na borda inferior (Leste): a faixa de costa com as praias que vai da ponta de Cabedelo até a Barra de Gramame.

Na borda lateral esquerda (Sul): o contorno de Mangabeira e o Distrito Industrial;

$\mathrm{Na}$ borda superior (Oeste): Aeroporto Castro Pinto, o município de Bayeux (sem a presença do nome) e os Rios Sanhauá e Paraíba.

$\mathrm{Na}$ borda lateral direita (Norte): Foz do rio Sanhauá e o município de Cabedelo.

Público Alvo: Turistas em geral.

Slogans e/ou frases de efeito: "onde o sol nasce primeiro nas Américas"

"a segunda capital mais verde do Brasil"

Principais pontos ou locais destacados: O destaque principal se dá no Manaíra Shopping.

Topônimos citados: Apenas Tambaba, Lucena são citados dentro do mapa. Outros topônimos são citados na legenda.

Instituição responsável por propor ou encomendar o mapa: Manaíra Shopping.

Empresa responsável pela execução do projeto, impressão do mapa: Não identificada.

Autor do mapa: Gilton Lira.

Ficha 45 

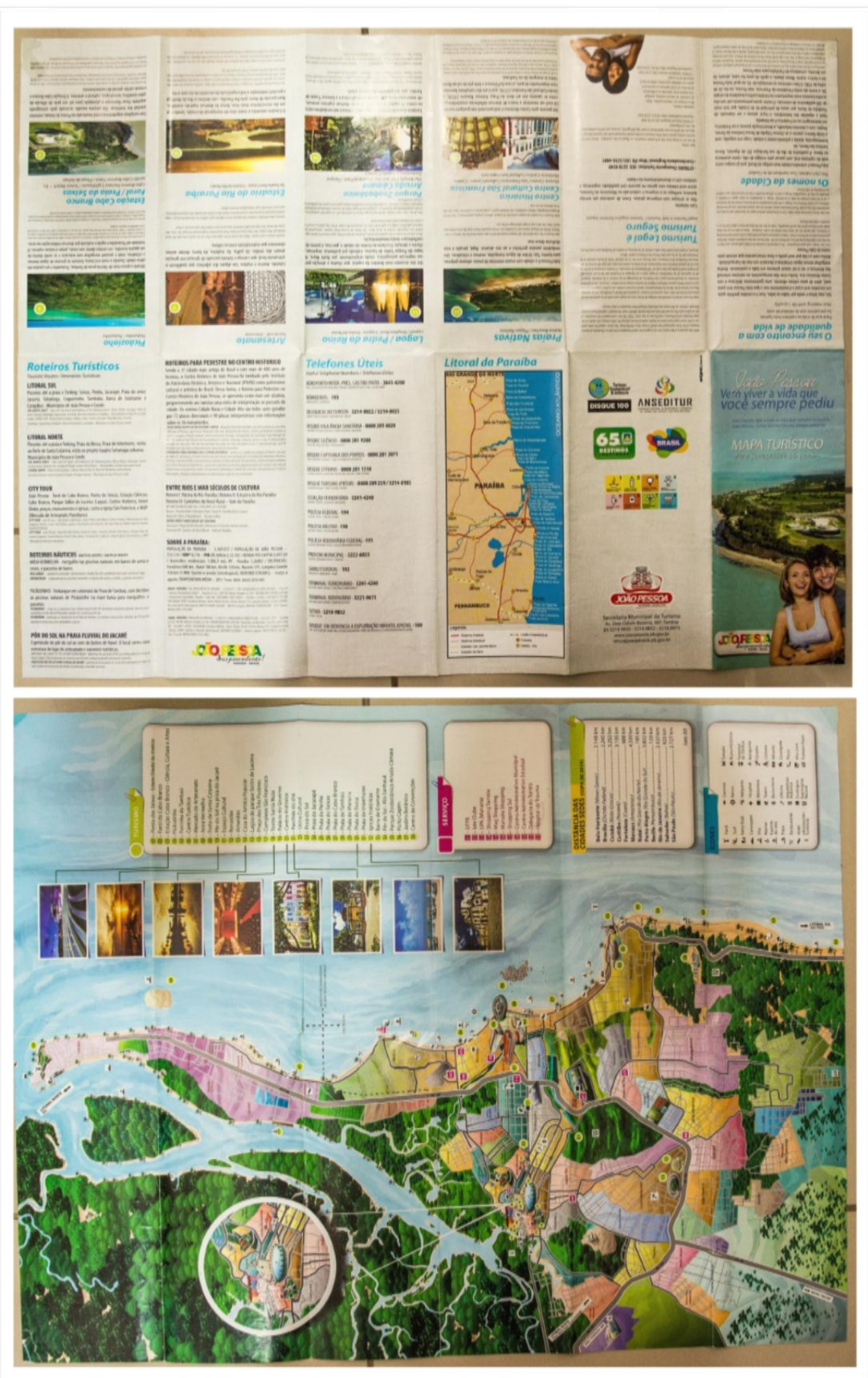

Mapa-Ficha 45 - Mapa Turístico "Vem viver a vida que você sempre pediu". Data 2010.

Ficha 45 - Período/Ano de publicação: 2010. 
Observações: data presumida pela logomarca do Governo Federal lançada em 2010 e dados estatísticos sobre a cidade com referência de 2010.

Breve descrição: Folder institucional, dobrável, com um mapa em um dos lados e informações e fotografias de lugares turísticos no outro lado do material, além de constar também para cada fotografia uma breve explicação sobre o ponto turístico.

Mapa sem borda e sem título. Apresenta um "zoom" da área do Centro Histórico da cidade destacando a Lagoa do Parque Solon de Lucena. Os principais pontos da cidade estão numerados e organizados em uma legenda do lado direito do mapa. Oito fotografias de locais turísticos estão colocadas ao lado desta legenda, sendo estas: Estação Ciências, Pôr do Sol na praia do Jacaré, Lagoa do Parque Solón de Lucena, Teatro Santa Roza, Centro histórico, Pavilhão do Chá, Praia do Bessa, Igreja do Bispo,

Tipo de suporte: (folder, encarte, para parede, etc): Folder

Título dofolder: Mapa Turístico: Vem viver a vida que você sempre pediu.

Título do mapa: Não consta título.

Ponto de vista do observador (ou usuário do mapa): Tomada vertical.

Foto da capa: Fotografia da Ponta do Cabo Branco, com destaque para a Estação Ciências. (Destaca-se, sobreposto à fotografia um casal jovem com um sorriso).

Escala: Não consta.

Rosa dos Ventos: Não consta.

Os limites representados (as bordas do espaço representado): A área total da cidade.

Público alvo: Turistas em geral.

Slogans e/ou frases de efeito: "Extremo oriental das Américas".

Instituição responsável por propor ou encomendar o mapa: Prefeitura Municipal de João Pessoa.

Empresa responsável pela execução do projeto, impressão do mapa: Antares / AbapPB

Prefeito da época: José Luciano Agra de Oliveira.

Autor do mapa: Não identificado. 
Ficha 46

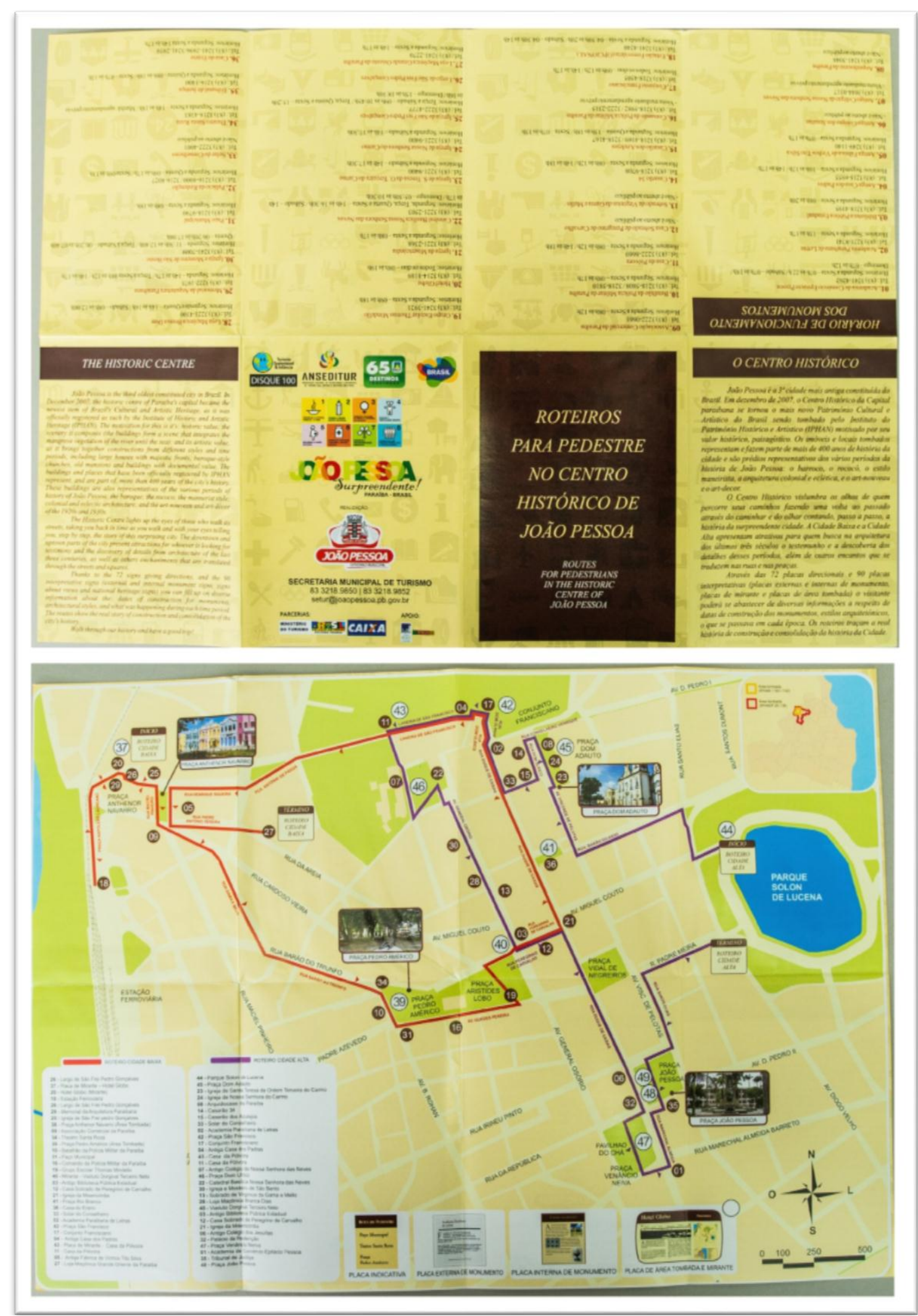

Mapa-Ficha 46 - Roteiros para pedestres no Centro Histórico de João Pessoa. Data: 2010. 
Ficha 46 - Período/Ano de publicação: 2010.

Observação: Data presumida pela logomarca do governo federal.

Breve descrição:

Mapa folder exclusivamente do Centro Histórico da cidade.

Contém um texto explicativo com a tradução em inglês.

Apresenta dois roteiros a serem seguidos: um para a cidade alta e outro para a cidade baixa.

Apresenta legenda numerada com os pontos a serem visitados.

Apresentam fotografias de alguns pontos a serem visitados.

Suporte (folder, encarte, para parede, etc): Mapa Folder

Título do Folder: Roteiros para pedestres no Centro Histórico de João Pessoa (Consta o título em inglês também)

Título do Mapa: Não consta título.

Ponto de vista do observador (ou usuário do mapa): Ponto de vista vertical.

Foto da capa: Não consta foto.

Escala: Apresenta escala gráfica

Rosa dos ventos: Sim.

Os limites representados (as bordas do espaço representado):

Na borda norte o conjunto Franciscano;

Na borda sul a rua da República, pça Venâncio Neiva e Pavilhão do Chá.

No lado leste o Parque Solón de Lucena

Na parte oeste a Estação Ferroviária

Principais pontos ou locais destacados: O Parque Solon de Lucena.

Público alvo: Turistas interessados em aspectos históricos e arquitetônicos.

Slogans e/ou frases de efeito: Não identificados.

Principais pontos ou locais destacados: Contém fotos dos seguintes locais: Praça Anthenor Navarro, Praça Pedro Américo, Praça Dom Adauto, Praça João Pessoa.

Topônimos citados: Algumas ruas e Praças, o Parque Solon de Lucena,

Instituição responsável por propor ou encomendar o mapa: Prefeitura Municipal /

Secretaria municipal de Turismo em parceria com o Ministério do Turismo e Caixa Econômica.

Empresa responsável pela execução do projeto, impressão do mapa: Não identificada. Prefeito da época: Ricardo Coutinho.

Autor do mapa: Não identificado. 
Ficha 47
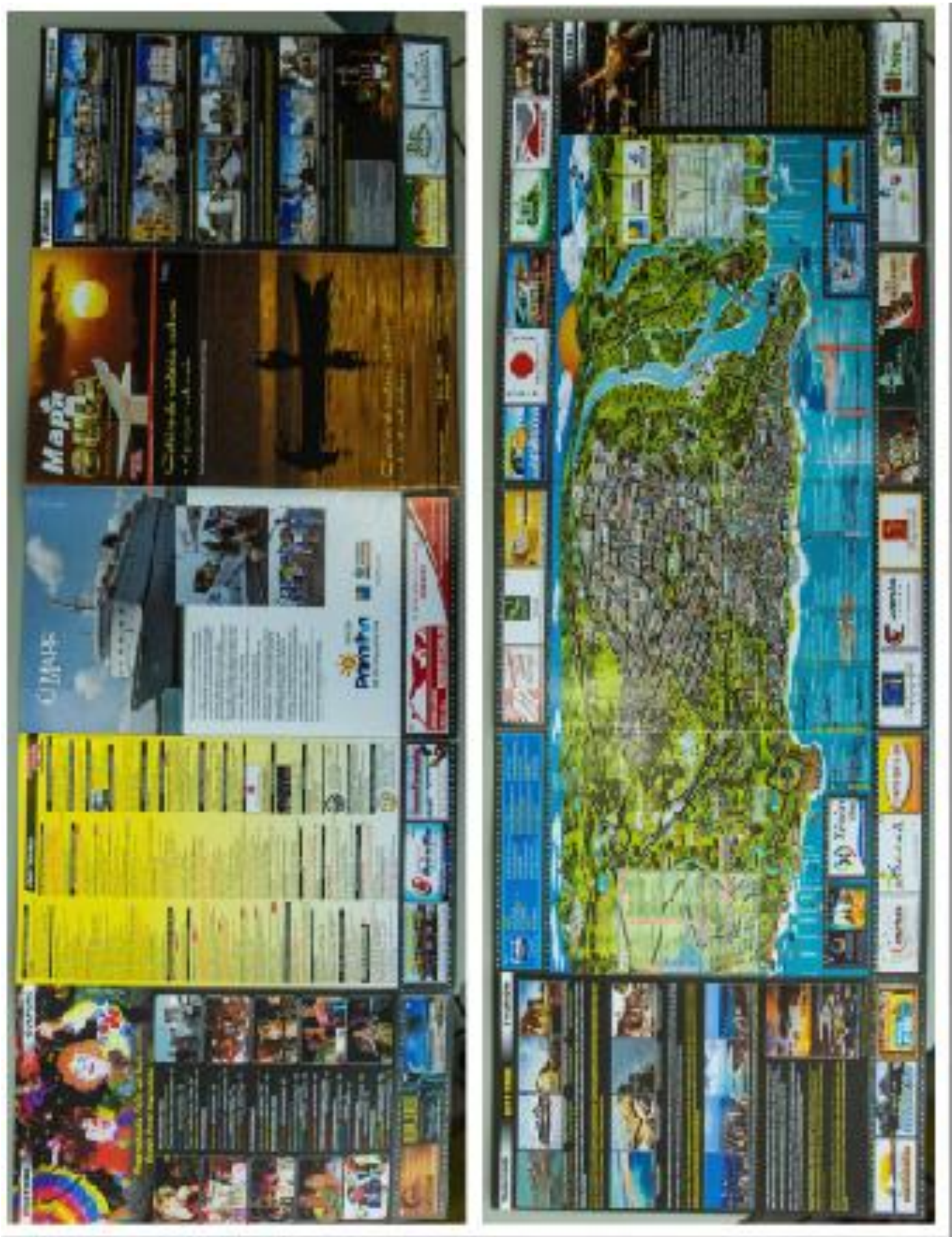

Mapa-Ficha 47 - Mapa Guia Turístico Cultural de João Pessoa "Celeiro de história, cultura e riquezas naturais. Data Fev./Mar. 2010. 
Ficha 47 - Período/ano da publicação: Fev./Mar. 2010

Breve descrição: Mapa-Guia turístico em formato de folder dobrável. De um lado consta o mapa e, do outro lado, informações, referências turísticas e publicidades de empresas ligas ao setor. Consta também a programação cultural da cidade no período.

Tipo de suporte (folder, encarte, para parede, etc): Folder.

Título do folder: Guia sequencial turístico cultural de João Pessoa: Celeiro de História, cultura e riquezas naturias.

Título do mapa: Não consta título no mapa.

Ponto de vista do observador: Vista sentido de leste para oeste.

Foto da capa: Por do sol na Praia do Jacaré, com Jurandi do Sax no barco tocando o Bolero de Ravel.

Escala: não consta.

\section{Rosa dos ventos: Sim.}

Os limites representados (ou as bordas do espaço representado pelo mapa): Os limites na borda lateral direita do (norte o município) são: a ponta de Cabedelo, a Ilha da Restinga e a ponta de Costinha. Na borda lateral esquerda do mapa (sul de João Pessoa) os limites são a praia da Penha e mais acima a sudoeste do mapa, o contorno que limita os bairros Bancários e Mangabeira, e as proximidades do Distrito Industrial da cidade. A oeste e a noroeste do mapa o rio Sanhauá é o limite. Na borda inferior (leste) a faixa litorânea é o limite da representação do mapa.

Público alvo: Turistas em geral.

Slogans e/ou frases de efeito: Farol do Cabo Branco extremo oriental das Américas, onde o sol e a lua nascem primeiro na cidade mais verde do continente Americano". "Viva essa energia, sinta essa alegria".

Principais pontos ou locais destacados: Forte de Cabedelo, Farol do Cabo Branco, Lagoa, Hotel Tambaú, Praia do Jacaré.

Topônimos citados: Principais ruas e avenidas da cidade. Praias: Sagi, Camaratuba, Praia do Forte, Baía da Traíção, Ponta de Areia, Barra de Mamanguape, Campina, Lucena, Jacaré, Cabedelo, Costinha, Fagundes, Miramar, Ponta de Mato, Formosa, Areia Dourada, Camboinha, Poço, Intermares, Bessa, Manaíra, Tambaú, Cabo Branco, Seixas, Penha, Jacarapé, Praia do Sol, Barra de Gramame, Praia do Amor, Jacumã, Carapibus, Tabatinga, Coqueirinho, Tambaba, Praia Bela. Rios: Paraíba, Sanhauá, Mamanguape. Outros: Ilha da Restinga, Ilha das Andorinhas, Ilha do Stuart, Forte Velho, Mataraca, Baía da Traíção.

Instituição responsável por propor ou encomendar o mapa: Prefeitura municipal Empresa responsável pela execução do projeto, impressão do mapa: Gráfica JB Autor do mapa: Rodolfo Stuckert. 


\section{Ficha 48}

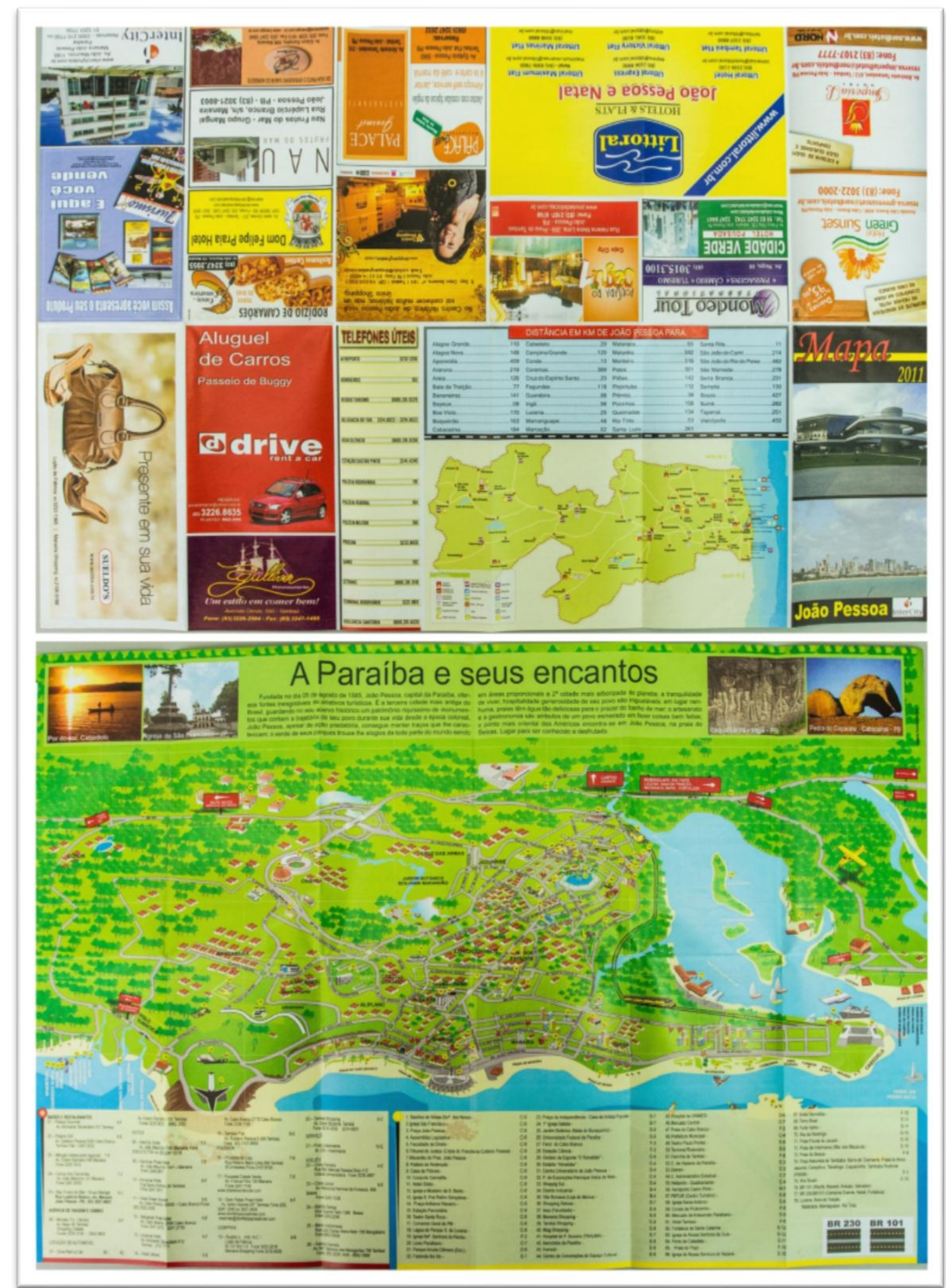

Mapa-Ficha 48 - Mapa Turístico A Paraíba e seus encantos. Data: 2011. 
Ficha 48 - Período/ano de publicação: 2011.

Observações interessantes: Neste mapa a data consta na capa do folder.

- Existe uma legenda onde se distinguem locais de serviços (Hotéis e pousadas, lojas, locadoras e serviços turísticos em geral) e locais considerados de atração turística. Percebemos que o hotel Tambaú não consta na lista de serviços e sim na lista de atrações turísticas.

- Este mapa é semelhante aos mapas das fichas 37 e 35, no entanto foi eliminada uma parte do lado direito do mapa que retirou da representação o município de Mataraca no litoral norte, ficando como limite deste lado o município de Cabedelo. Com isso a "escala do mapa aumentou" aumentando um pouco mais os ícones de representação dos pontos turísticos: Barreira do Cabo Branco e o Farol, o Forte de Cabedelo, O hotel Tambaú (que chega a ser maior do que o estádio de futebol o Almeidão) e a Lagoa do Parque Sólon de Lucena que toma proporções bem maiores do que a real.

Breve descrição: Mapa folder dobrável, de um lado consta o mapa turístico da cidade de João Pessoa e do outro lado constam diversas publicidades de empresas, um mapa do Estado da Paraíba, lista de telefones úteis, informações sobre distâncias entre algumas cidades e a capital, João Pessoa.

Na parte de cima do mapa, centralizado, consta o título "A Paraíba e seus encantos". Logo abaixo do título existe um pequeno texto de apresentação da cidade de João Pessoa. De um lado e do outro do título estão duas fotos: Do lado direito as fotos são das Itacoatiras do município de Ingá e a outra foto é da Pedra do Capacete em Cabaceiras. Do lado esquerdo as fotos são do Pôr do Sol em Cabedelo e a Igreja de São Francisco em João Pessoa.

Tipo de suporte (folder, encarte, para parede, etc): Folder.

Títutlo do folder: Mapa - João Pessoa: A Paraíba e seus encantos.

Título do mapa: A Paraíba e seus encantos.

Ponto de vista do observador (ou usuário do mapa): Vista no sentido de leste para oeste. Foto da capa: Duas fotos: uma da Estação Ciências e outra da praia do Cabo Branco Escala: Não consta.

Rosa dos ventos: Não consta.

Os limites representados (as bordas do espaço representado):

$\mathrm{Na}$ borda inferior Leste, todo o litoral do estado, desde o município de Cabedelo até as praias do litoral sul.

Na borda esquerda sul, as cidades de Pitimbu e Conde.

$\mathrm{Na}$ borda superior oeste, o Distrito Industrial, o Viaduto do Oitizeiro (Três Lagoas) e a BR 101.

Na borda direita Norte, o município de Cabedelo e a praia-ponta de Lucena.

Público alvo: Turistas em geral

Slogans e/ou frases de efeito: "Terceira cidade mais antiga do Brasil" "... 2 $2^{\mathrm{a}}$ cidade mais arborizada do planeta" 
“... o ponto mais oriental das Américas encontra-se em João Pessoa, na praia do Seixas."

Principais pontos ou locais destacados: Alguns ícones se destacam mais que outros por causa da proporção: O Hotel Tambaú, o Farol do Cabo Branco, o Forte de Cabedelo, a Lagoa do Parque Solon de Lucena.

Topônimos citados:

Principais vias de acesso;

Bairros: Jaguaribe, Centro, Torre, Expedicionários, Bairro dos Estado, Manaíra, Bessa, Cristo, Cruz das Armas, Mangabeira, Bancários, Castelo Branco, Altiplano, Tambauzinho, Miramar, Tambaú, Quadramares, Cabo Branco.

Municípios: Conde, Cabedelo.

Placas indicativas de saída para as cidades: Recife, Maceió, Aracaju, Salvador. Campina Grande, Mamanguape, Rio Tinto, Lucena, Baía da Traição, Mataraca, Natal, Fortaleza. Praias: Barra de Guaju, Barra de Camaratuba, Praia do Forte, Baia da Traição, Praia de Campina, Barra de Mamanguape, Lucena, Miramar, Ponta de Mato, Formosa, Areia Dourada, Camboinha, Poço, Intermares, Bessa, Manaíra, Tambaú, Cabo Branco, Seixas, Penha, Jacarapé, Praia do Sol, Barra de Gramame, Jacumã, Carapibus, Tabatinga, Coqueirinho, Tambaba, Pitimbu, Maceió, Ponta de coqueiros, Coqueiros.

Pontos turísticos: Costinha, Forte Velho, Ilha da Restinga, Ilha do Stuart, Ilha das Andorinhas, Praia Fluvial do Jacaré, Estação Ciências, Jardim Botânico Benjamin Maranhão, Farol da Pedra Seca.

Rios: Sanhauá, Mamanguape,

Instituição responsável por propor ou encomendar o mapa: Não identificada.

Empresa responsável pela execução do projeto, impressão do mapa: Duarte Comunicações.

Autor do mapa: Não identificado. 